\title{
Preparation of solid oxide fuel cell cathodes and analysis by impedance spectroscopy
}

\author{
Juwana Hennadige Lalanthi Kaushalya de Silva
}

Follow this and additional works at: https://researchrepository.wvu.edu/etd

\section{Recommended Citation}

de Silva, Juwana Hennadige Lalanthi Kaushalya, "Preparation of solid oxide fuel cell cathodes and analysis by impedance spectroscopy" (2014). Graduate Theses, Dissertations, and Problem Reports. 7078.

https://researchrepository.wvu.edu/etd/7078

This Dissertation is protected by copyright and/or related rights. It has been brought to you by the The Research Repository @ WVU with permission from the rights-holder(s). You are free to use this Dissertation in any way that is permitted by the copyright and related rights legislation that applies to your use. For other uses you must obtain permission from the rights-holder(s) directly, unless additional rights are indicated by a Creative Commons license in the record and/ or on the work itself. This Dissertation has been accepted for inclusion in WVU Graduate Theses, Dissertations, and Problem Reports collection by an authorized administrator of The Research Repository @ WVU.

For more information, please contact researchrepository@mail.wvu.edu. 
PREPARATION OF SOLID OXIDE FUEL CELL CATHODES AND ANALYSIS BY IMPEDANCE SPECTROSCOPY

\author{
Juwana Hennadige Lalanthi Kaushalya de Silva
}

Dissertation submitted to the Eberly College of Arts and Sciences

at West Virginia University in partial fulfillment of the requirements for the degree of

\author{
Doctor of Philosophy \\ in \\ Chemistry
}

\author{
Harry Finklea, Ph.D., Chair \\ Fabien Goulay, Ph.D. \\ Justin Legleiter, Ph.D. \\ Alan Stolzenberg, Ph.D. \\ Nianqiang Wu, Ph.D. \\ C. Eugene Bennett Department of Chemistry \\ Morgantown, West Virginia \\ 2014
}

Keywords: Solid Oxide Fuel Cell, Impedance Spectroscopy, Deconvolution, Infiltration, Current collector

Copyright 2014 Juwana H.L. Kaushalya de Silva 


\section{Abstract \\ Preparation of Solid Oxide Fuel Cell Cathodes and Analysis by Impedance Spectroscopy}

\section{Juwana Hennadige Lalanthi Kaushalya de Silva}

The solid oxide fuel cell (SOFC) is a promising energy conversion device with high efficiency, fuel flexibility and less pollution. The requirement for high operating temperatures limits its applications due to high cost and the need for compatible cell components. Therefore, it is important to design SOFCs that operate in intermediate temperatures; which have cathodes with improved microstructures to enhance the oxygen reduction reaction. However, designing novel cathode structures needs a fundamental understanding of cell processes. Impedance spectroscopy is a very powerful tool for studying SOFCs which yields useful yet complex data due to overlapping impedance related processes. Therefore, we used a deconvolution method to analyze the impedance data and extract information about individual processes through equivalent circuit fitting.

Current collectors play a vital role in SOFC characterization. Platinum (Pt), Gold ( $\mathrm{Au}$ ), Silver (Ag) and Lanthanum Strontium Manganite (LSM) are some commonly used cathode current collectors. We carried out a preliminary study in order to investigate the current collection properties of these materials and to choose the most suitable current collectors for our symmetrical cell characterizations. Based on the results (good adhesion properties and reproducible performance), it was decided continue to using Ag and LSM as the current collectors for our characterizations.

Cathode microstructure can be improved by increasing the triple phase boundary (TPB) area of a cathode. This can be done by developing composite cathode structures which consist of both electron and ion conducting phases. Traditionally, composited cathodes are formed by mixing powders of LSM and Yttria Stabilized Zirconia (YSZ) with high temperature sintering. More recently, the infiltration technique (infiltrating a pre-sintered YSZ scaffold with a LSM solution followed by low temperature sintering) has been used to prepare LSM-YSZ composite cathodes. A previous study has reported the performance comparison of LSM infiltrated YSZ nanofiber cathode with LSM-YSZ powder composite cathode. However, this work does not provide the deconvolution analysis of impedance data. In our work, the properties of LSM infiltrated YSZ nanofiber cathodes and LSM infiltrated YSZ powder cathodes were compared. LSM infiltrated YSZ nanofiber cathodes showed better performance compared to LSM infiltrated YSZ powder cathodes and deconvoluted impedance data for both types of cells showed "Gerischer" like behavior which arises due to the thickness of the cathode. Based on this knowledge, an attempt was made to prepare improved LSM infiltrated YSZ cathodes with thin YSZ scaffolds.

LSM cathodes are usually prepared using the pastes of commercial LSM powders. Despite the extensive studies carried out on LSM infiltrated YSZ cathodes, to the best of our knowledge, no attempt has been made to study the activity of the infiltrant LSM alone as a cathode. In this work, symmetrical cells with cathodes prepared by evaporating and 
sintering LSM infiltrant solution directly on YSZ electrolytes were characterized using Ag, $\mathrm{Au}$ and Pt current collectors. Impedance studies of solution-based LSM cathodes with Ag current collectors resulted in very low polarization resistances (resistance associated with the oxygen reduction reaction) and 2-3 orders of magnitude higher peak frequencies compared to powder based LSM cathodes. Properties of these solution based LSM cathodes vary with different current collectors, which suggests that the current collector participates in the oxygen reduction reaction of the solution based LSM cathodes. Nonetheless, it would be possible to further investigate and develop these "solution-based LSM cathodes with Ag current collectors" as a composite cathode for intermediate temperature SOFCs.

The significant difference of peak frequencies between the powder based and solution based LSM cathodes led to an investigation of LSM-YSZ hybrid cells (powder based LSM cathode as the working electrode and solution based LSM cathode with Ag current collector as counter electrode) in order to isolate and study the properties of powder based LSM cathode with minimal overlapping impedance processes. According to our knowledge, this direct method that we have used to study a single electrode under applied DC bias has not been reported before.

Also, using the measurements at open circuit voltage (OCV) and with applied DC bias, we have demonstrated that the properties of the powder based LSM cathode change with time and applied potential/current, at unexpectedly low overvoltages. This observation suggests that the use of Butler-Volmer equation to represent current-potential behavior in simulations may be inappropriate. 
Dedicated to my father J. H. Ranjith Jayantha and my mother Hemavo Wijetunge. 


\section{Acknowledgements}

First and foremost I would like to express my sincere gratitude to my Ph.D. advisor Dr. Harry Finklea for the tremendous support given to me during last five years. Dr. Finklea was always available and willing to help me with all kinds of questions and concerns I had and spent many hours helping me with experiments, discussing my results and editing my dissertation. I am so grateful to Dr. Finklea for his helpfulness, friendliness and patience and I consider myself very lucky to have worked with such a great teacher, a renowned scientist and a wonderful person.

I am very grateful to Dr. Fabien Goulay, Dr. Justin Legleiter, Dr. Alan Stolzenberg and Dr. Nick Wu for serving in my graduate committee and for helping me in numerous ways despite their busy schedules. Also, their advice and suggestions are greatly appreciated.

I am thankful to Dr. Nick Wu and Dr. Mingjia Zhi (MAE-WVU) for providing me with YSZ nanofibers, Dr. Edward Sabolsky (MAE-WVU) for providing me with the ink vehicle and Dr. Alan Stolzenberg (Chemistry-WVU) for allowing me to borrow the WIG-L-BUG. I would also like to acknowledge Dr. Lisa Holland and Tyler Davis (Chemistry -WVU) for the support given to me during HF-etching experiments; Dr. Jonathan Boyd, Julie Vrana and Alice Han (Chemistry-WVU) for helping me with freeze-drying experiments; Dr. Peter Gannett and Katherine Hickey (HSC-WVU) for facilitating the contact angle goniometry measurements; Dr. Jingxin Wang and Dr. Xingeng Xie (Forestry-WVU) for their help with the TGA experiments; Dr. Kirk Gerdes and Dr. Harry Abernathy (NETL-Morgantown) for the support given to me to conduct $\mathrm{pO}_{2}$ experiments; James Poston (NETL-Morgantown) for providing me with the XRD data for LSM; and Sherman Adams, Allen Burns and Randall Eaglen for helping me to develop experimental set ups without any delays.

I would also like to thank the NETL-RUA for funding and the Solid Oxide Fuel Cell research team at NETL-Morgantown for helping me in numerous ways.

It was a pleasure to work with my group members Dr. Oktay Demircan, Dr. Yun Chen, Dr. Xiaoke Chen, Dr. Wei Zhang and Mahfuzur Jony. I would especially like to thank Mahfuzur Jony for providing me with all the SEM images and EDS spectra which were 
very important for my dissertation. I would also like to thank my friends at WVU and my Sri Lankan friends in Morgantown for all their support and for the great times we had.

I am very grateful to my wonderful parents (J.H. Ranjith Jayantha and Hemavo Wijetunge), awesome siblings (Madhubhani, Sankha and Ludilu) and lovely grandparents (Edwin Silva, Aceda Mallika, Ranjani Wijetunge and late Dairas Wijetunge) for their unconditional love and constant support. They always believed in me and encouraged me to do my best.

Last but not least, I would like to take this opportunity to thank my amazing husband (Oshadha Ranasingha) for always being there for me and supporting me to achieve the best in life.

As part of the National Energy Technology Laboratory's Regional University Alliance (NETL-RUA), a collaborative initiative of the NETL, this technical effort was performed under the RES contract DE-FE0004000. 


\section{Table of Contents}

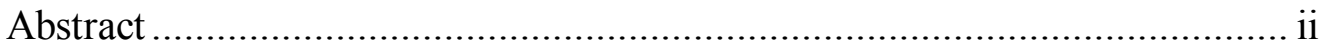

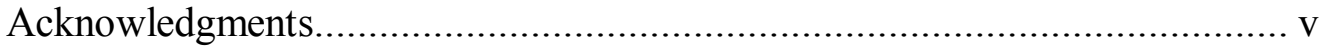

Table of Contents........................................................................... vii

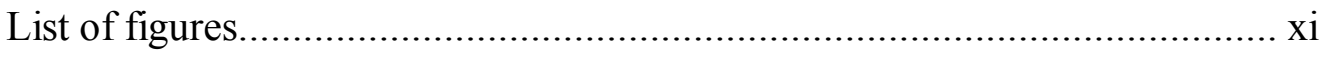

List of tables ...................................................................................... Xviii

Abbreviations.....................................................................................

Chapter 01: Introduction............................................................................................. 1

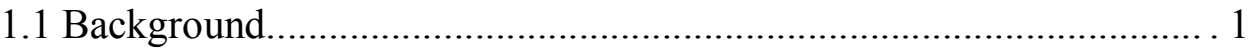

1.2 Solid Oxide Fuel Cells........................................... 1

1.3 Oxygen Reduction Reaction.......................................................... . 4

1.4 Symmetrical Cells ................................................................. 6

1.5 Current Collectors..................................................................... 7

1.6 Electrochemical Characterization ............................................ 7

1.7 Equivalent Circuit Elements and Electrochemical Processes .............. 9

1.8 Challenges for Solid Oxide Fuel Cells ......................................... 14

1.9 Objectives and the Structure of the Dissertation ......................... 15

1.10 References ..................................................................... 16

Chapter 02: (Section I) Metal And LSM Current Collectors .......................18

2.1 Introduction .................................................................... 18

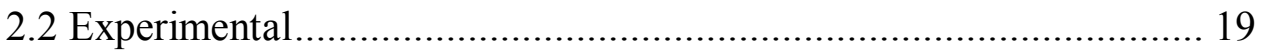

2.2.1 Cyclic Voltammetry Measurements.................................. 20

2.2.2 Electrochemical Impedance Spectroscopy Measurements...... 20

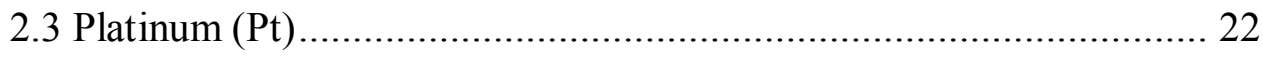

2.3.1 Introduction ............................................................ 22

2.3.2 Sample Preparation ......................................................... 22

2.3.3 Electrochemical Characterization ................................. 22

2.3.4 Results and Discussion................................................ 23

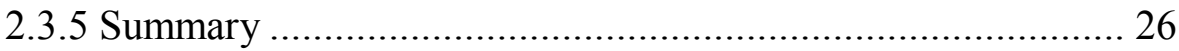

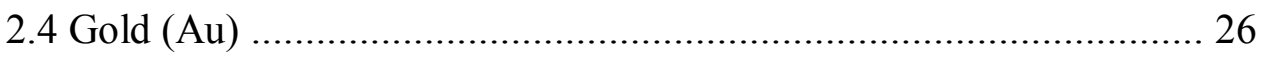

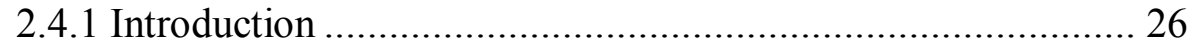




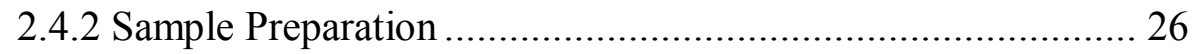

2.4.3 Electrochemical Characterization ............................................. 27

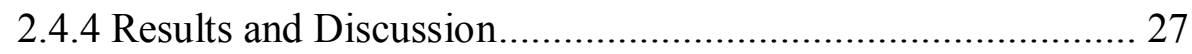

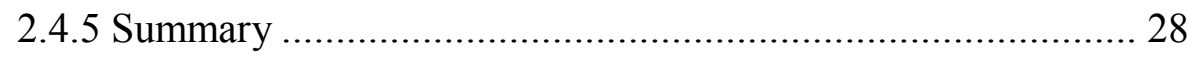

2.5 Silver (Ag)

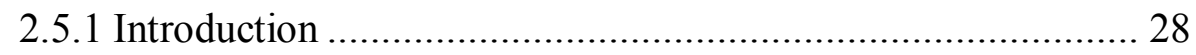

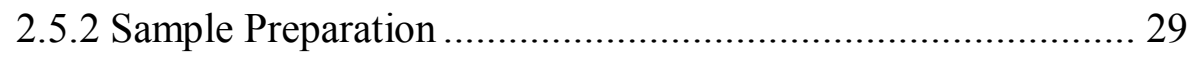

2.5.3 Electrochemical Characterization ........................................... 29

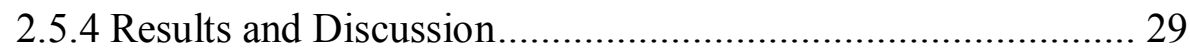

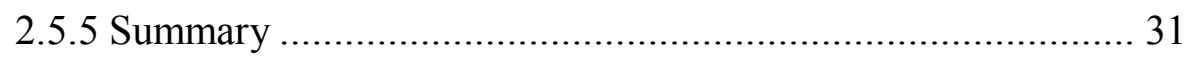

2.6 Lanthanum Strontium Manganite (LSM) ……………………….... 32

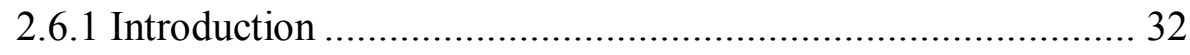

2.6.2 Sample Preparation .......................................................... 32

2.6.3 Electrochemical Characterization ............................................ 32

2.6.4 Results and Discussion........................................................... 32

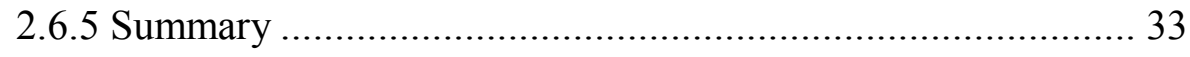

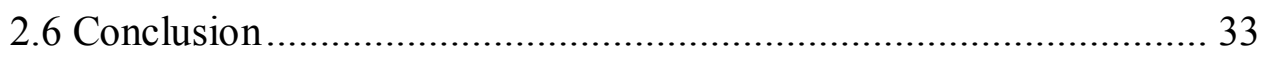

Chapter 02: (Section II) YSZ Nanofiber Cathodes (PAR System) ............35

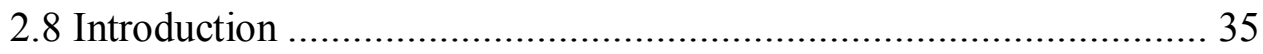

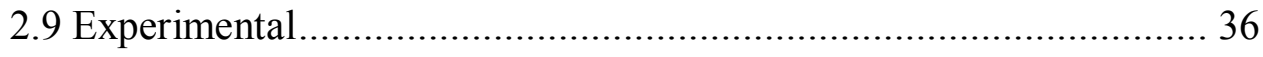

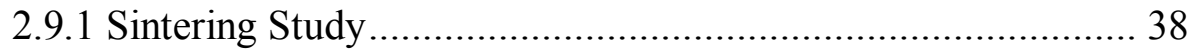

2.9.2 Electrochemical Characterization ………………………......... 38

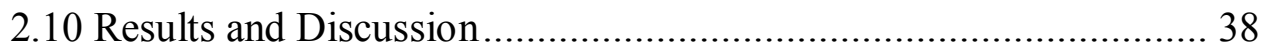

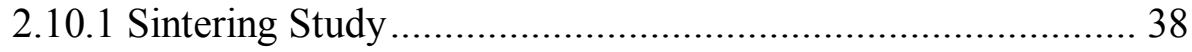

2.10.2 Pt current collectors on YSZ nanofiber cathodes .................... 40

2.10.3 Au current collectors on YSZ nanofiber cathodes ................... 42

2.10.4 Ag current collectors on YSZ nanofiber cathodes .................... 43

2.10.5 Ag current collectors on YSZ powder cathodes....................... 47

2.10.6 Ag current collectors on LSM infiltrated YSZ cathodes.......... 49

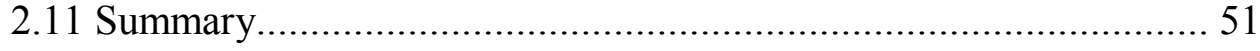

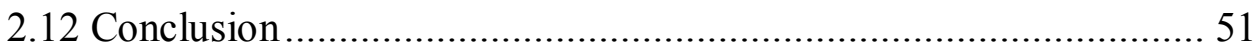




\section{Chapter 03: LSM current collectors and LSM infiltrated YSZ}

Scaffolds........................................................................................54

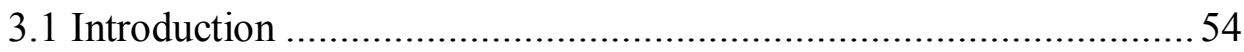

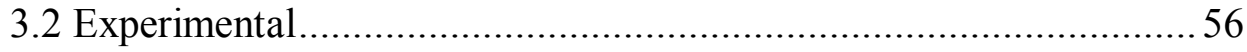

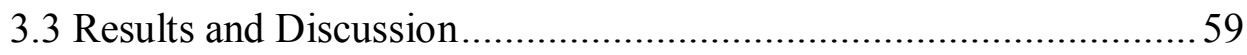

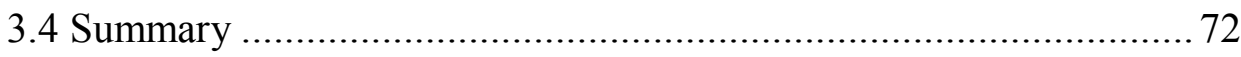

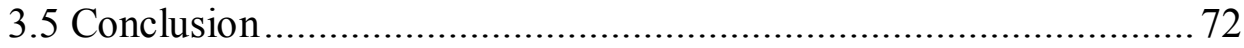

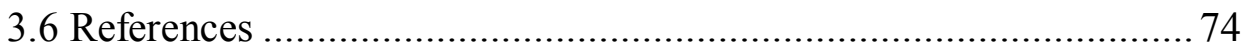

\section{Chapter 04: Solid Oxide Fuel Cell Cathodes and Deconvolution}

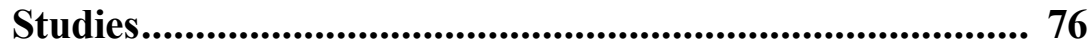

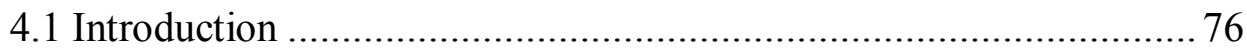

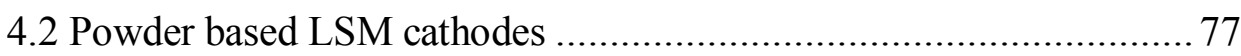

4.2.1 Sintering Study of LSM powder cathodes................................ 78

4.2.2 Aging Study of LSM powder/YSZ symmetrical cells ...............79

4.2.3 Deconvolution studies of LSM powder/YSZ symmetrical

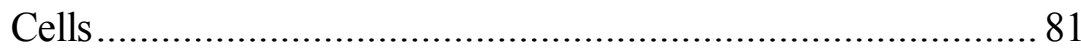

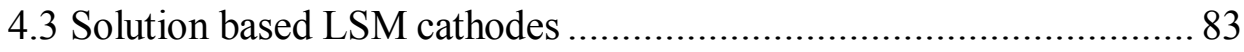

4.3.1 Contact Angle Measurements ................................................. 84

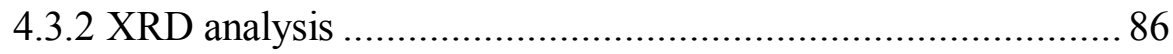

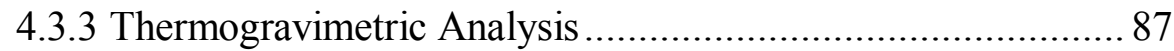

4.3.4 Sintering study of LSM solution based cathodes..................... 88

4.3.5 Aging Study of LSM solution/YSZ symmetrical cells with

Ag current collectors.............................................................. 92

4.3.6 Deconvolution studies of LSM solution/YSZ symmetrical cells

Ag current collectors............................................................ 95

4.3.7 LSM solution/YSZ symmetrical cells with different metal current collectors................................................................. 96

4.3.8 "Mixed" Performance of solution based LSM cathodes with Ag current collectors.............................................................. 102

4.3.9 LSM solution/HIONIC ${ }^{\circledR}$ symmetrical cells............................106 
4.3.10 Ag/organic LSM/YSZ symmetrical cells with different oxygen partial pressures ............................................... 108

4.4 Deconvolution study of LSM infiltrated YSZ cathodes .................110

4.5 Summary ......................................................................... 114

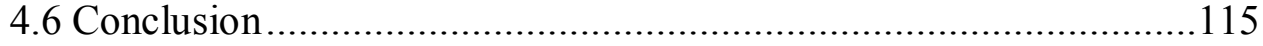

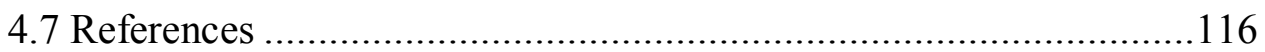

Chapter 05: LSM/YSZ Hybrid Cells ..............................................119

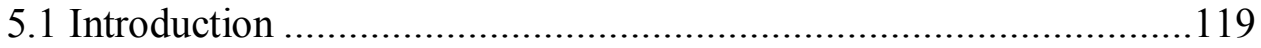

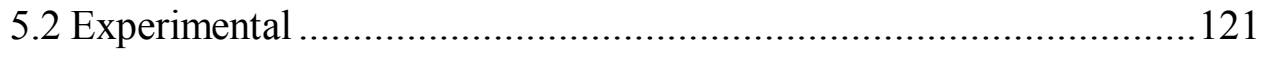

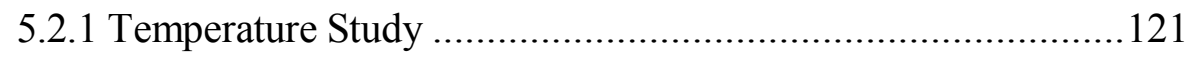

5.2.2 LSM/YSZ Hybrid Cell Characterization under Polarization ............................................................... 123

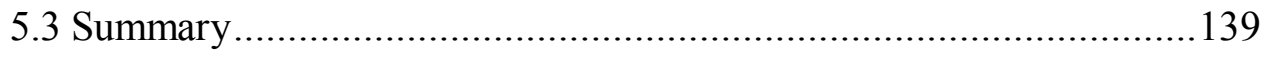

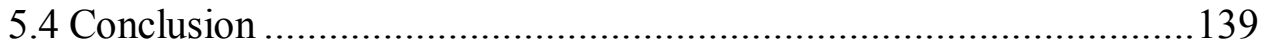

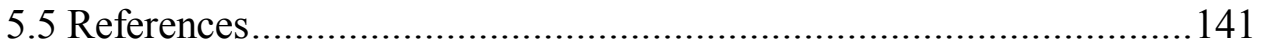

Appendix A 


\section{List of Figures}

Figure 1.1: Schematic diagram of a Solid Oxide Fuel Cell ......................... 2

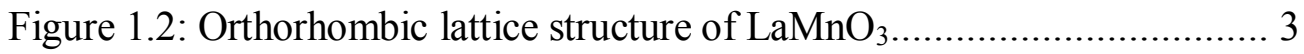

Figure 1.3: Triple Phase Boundary of LSM cathode on YSZ electrolyte........ 4

Figure 1.4: Cathodic reaction paths on electron conducting perovskite

materials 5

Figure 1.5: Schematic diagram of a LSM/YSZ/LSM symmetrical cell operating in air ............................................................ 7

Figure 1.6: Nyquist plot with EIS data .............................................. 8

Figure 1.7: The polarization curve (black) and the power curve (red) for a single SOFC 9

Figure 1.8: A Bode plot (a) and the corresponding deconvoluted spectrum (b) which reveals the peaks/shoulders for three possible impedance processes

Figure 1.9: Bode plots (-Z" vs log f): (RC) and (RQ) elements with varying exponent $U$ values shown. The arc is symmetrical in the left plot. In the double log plot, the magnitudes of the slopes of the lines away from the peak frequency are equal to the $U$ value....... 12

Figure 1.10: Representing a porous electrode as a series of cylindrical pores. 13

Figure 1.11: Fractal Gerischer element with varying P values. The Bode plot is asymmetrical with a long tail on the high frequency side. The double log plot shows that the slope on the low frequency side is 1 and the magnitude of the slope on the high frequency side is $\mathrm{P}$

Figure 1.12: $\mathrm{HN}$ element with $\mathrm{P}=0.5$ and varying $\mathrm{U}$ values. The Bode plot is again asymmetrical with a long tail on the high frequency side. The magnitude of the slope of the log log plot approaches $\mathrm{U}$ on the low frequency side and $\mathrm{P}^{*} \mathrm{U}$ on the high frequency side. 14

Figure 2.1 Cross section of the tube furnace when the cell is mounted .19 
Figure 2.2: Voltammogram for a Pt/YSZ nanofiber/YSZ symmetrical cell $(\mathrm{d}=4 \mathrm{~mm})$ at $700^{\circ} \mathrm{C}$. The total resistance calculated by the reciprocal slope of the line is $4.36 \mathrm{kOhms}$

Figure 2.3: A plot of EIS data for a Pt/Roughened YSZ/Pt symmetric cell at $700^{\circ} \mathrm{C}$. The series resistance obtained by the high frequency intercept is $11.2 \mathrm{Ohms}$

Figure 2.4: Arrhenius plot for the series resistance $\left(\mathrm{R}_{\mathrm{s}}\right)$ and the deduced activation energy for the oxide ion conductivity across the cell. Slope $=11565+/-453$, Intercept $=-9.5+/-0.4, R^{2}=0.997$, $\mathrm{E}_{\mathrm{a}}=1.00+/-0.04 \mathrm{eV}$

Figure 2.5: Arrhenius plot for the polarization resistance $\left(R_{p}\right)$ and the deduced activation energy for the oxygen reduction reaction at the cathode. Slope $=32300+/-1173$, Intercept $=-24+/-1$, $\mathrm{R}^{2}=0.997, \mathrm{E}_{\mathrm{a}}=2.8+/-0.1 \mathrm{eV}$

Figure 2.6: SEM images of a (a) YSZ nanofiber cathode sintered at $1300{ }^{\circ} \mathrm{C}$ (3000 X) and (b) YSZ powder cathode sintered at $1500{ }^{\circ} \mathrm{C}$ $(5000 \mathrm{X})$ on YSZ electrolyte.

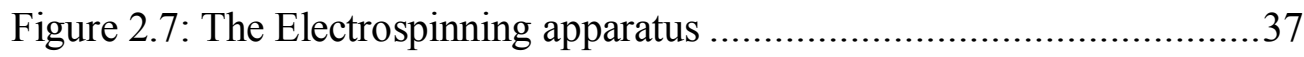

Figure 2.8: Schematic diagram of a Solid Oxide Fuel Cell ...........................37

Figure 2.9: SEM images of YSZ nanofibers sintered at (a) $850{ }^{\circ} \mathrm{C}(3500 \mathrm{X})$,

(b) $1100{ }^{\circ} \mathrm{C}(6000 \mathrm{X})$, (c) $1150{ }^{\circ} \mathrm{C}(7000 \mathrm{X})$, (d) $1200{ }^{\circ} \mathrm{C}(7000 \mathrm{X})$,

(e) $1250{ }^{\circ} \mathrm{C}(8000 \mathrm{X}),(\mathrm{f}) 1300{ }^{\circ} \mathrm{C}(12000 \mathrm{X}),(\mathrm{g}) 1350{ }^{\circ} \mathrm{C}$

$(3000 \mathrm{X}),(\mathrm{h}) 1400{ }^{0} \mathrm{C}(10000 \mathrm{X})$ and (i) $1450{ }^{\circ} \mathrm{C}(5000 \mathrm{X})$.

Figure 2.10: $\mathrm{YSZ}$ nanofibers sintered with $\mathrm{Bi}\left(\mathrm{NO}_{3}\right)_{3}$ at $850{ }^{\circ} \mathrm{C}$, nanofibers are melted

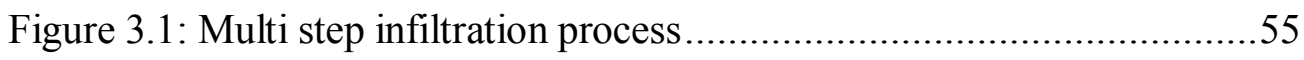

Figure 3.2: Discrete particles (c) or continuous thin film (d) on the cathode backbone

Figure 3.3: Cross section SEM image of YSZ nanofiber electrode prepared using the paste that was not ball-milled. Red squares highlight the gaps..... 
Figure 3.4: Cross section SEM image of YSZ nanofiber electrode prepared using the ball milled paste. Blue square shows the uniform electrode and the electrolyte

Figure 3.5: SEM images of 30\% LSM infiltrated (a) YSZ nanofiber cathode (b) YSZ powder cathode.... .70

Figure 3.6: EDS spectrum for the LSM infiltrated YSZ nanofiber cathode ....70

Figure 4.1: SEM image of an LSM cathode sintered at $1200{ }^{\circ} \mathrm{C}$ for 1 hour....79

Figure 4.2: Polarization resistances recorded over time during the aging experiment for LSM powder cathode sintered at $1200{ }^{0} \mathrm{C}$ on YSZ. This figure shows the cathode behavior vs. time over the entire experiment 80

Figure 4.3: Polarization resistances recorded at (a) $700{ }^{0} \mathrm{C}$ and (b) $800{ }^{0} \mathrm{C}$ for aging of LSM powder cathode sintered at $1200{ }^{\circ} \mathrm{C}$ on YSZ. This figure shows the cathode behavior vs. time from the temperature change. At the beginning of Day 2 and Day 4, the cell temperature was dropped from $800{ }^{0} \mathrm{C}$ to $700{ }^{0} \mathrm{C}$. At the beginning of Day 3 and Day 5, the cell temperature was raised

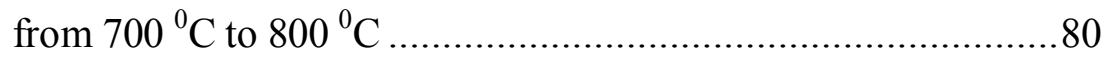

Figure 4.4: Deconvoluted and simulated data for LSM powder/YSZ symmetrical cells at $800{ }^{\circ} \mathrm{C}$ with (a) Ag (b) Pt and (c) Au current collectors (d) negative out of phase impedance vs log frequency plot with equivalent circuit fitting ( 3 RQ elements) of

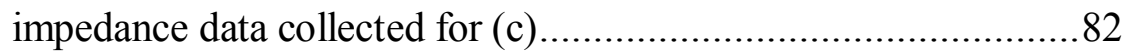

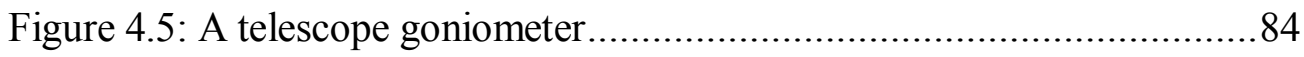

Figure 4.6: Different contact angle measurements ..................................85

Figure 4.7: Contact angle measurements for aqueous LSM solution on as received YSZ (a) and hydrophilic YSZ (b) and organic LSM solution on as received YSZ (c) and hydrophilic YSZ (d) ..........85

Figure 4.8: XRD data for aqueous LSM (a) and organic LSM (b) ...............86 Figure 4.9: Thermograms for organic (blue) and aqueous (red) LSM 
precursor solutions.

Figure 4.10: ESEM image of an organic LSM cathode sintered at $800{ }^{\circ} \mathrm{C}$ for 1 hour, $5000 \mathrm{X}$ magnification, $900{ }^{0} \mathrm{C}$ imaging temperature ......91

Figure 4.11: Polarization resistances recorded over time during the aging experiment for organic LSM solution cathode (with $\mathrm{Ag}$ current collector) sintered at $900{ }^{0} \mathrm{C}$ on YSZ at (a) $700{ }^{0} \mathrm{C}$ and (b) $800{ }^{\circ} \mathrm{C}$. This figure shows the cathode behavior vs. time over the entire experiment

Figure 4.12: Polarization resistances recorded at (a) $700{ }^{\circ} \mathrm{C}$ and (b) $800{ }^{0} \mathrm{C}$ for aging of organic LSM solution cathode (with Ag current collector) sintered at $900{ }^{0} \mathrm{C}$ on YSZ. This figure shows the cathode behavior vs. time from the temperature change. At the beginning of Day 2 and Day 4, the cell temperature was dropped from $800{ }^{0} \mathrm{C}$ to $700{ }^{\circ} \mathrm{C}$. At the beginning of Day 3 and Day 5, the cell temperature was raised from $700{ }^{0} \mathrm{C}$ to $800{ }^{0} \mathrm{C}$

Figure 4.13: Polarization resistances recorded over time during the aging experiment for organic LSM solution cathode (with $\mathrm{Ag}$ current collector) sintered at $1200{ }^{0} \mathrm{C}$ on YSZ. This figure shows the cathode behavior vs. time over the entire experiment

Figure 4.14: Figure 4.14: Polarization resistances recorded at (a) $700{ }^{0} \mathrm{C}$ and (b) $800{ }^{\circ} \mathrm{C}$ for aging of organic LSM solution cathode (with Ag current collector) sintered at $1200{ }^{\circ} \mathrm{C}$ on YSZ. This figure shows the cathode behavior vs. time from the temperature change. At the beginning of Day 2 and Day 4, the cell temperature was dropped from $800{ }^{0} \mathrm{C}$ to $700{ }^{\circ} \mathrm{C}$. At the beginning of Day 3 and Day 5, the cell temperature was raised from $700{ }^{0} \mathrm{C}$ to $800{ }^{\circ} \mathrm{C}$.

Figure 4.15: Deconvoluted (blue) and simulated (red) data at $800{ }^{0} \mathrm{C}$ for Ag/organic LSM/YSZ symmetrical cell sintered at $900{ }^{\circ} \mathrm{C}$ 
Figure 4.16: Deconvoluted (blue) and simulated (red) data at $800^{\circ} \mathrm{C}$ for (i) Ag (thick)/YSZ (ii) Ag (thin)/YSZ (iii) Ag powder/YSZ and (iv) $\mathrm{Pt} /$ YSZ symmetrical cells

Figure 4.17: Deconvoluted (blue) and simulated (red) data at $800{ }^{\circ} \mathrm{C}$ for (v) Pt/organic LSM/YSZ (vi) Au/organic LSM/YSZ symmetrical cells

Figure 4.18: Deconvoluted (blue) and simulated (red) data at $800{ }^{0} \mathrm{C}$ for Ag/organic LSM/YSZ symmetrical cell sintered at $1200{ }^{\circ} \mathrm{C} \ldots . .103$

Figure 4.19: Deconvoluted and simulated data for Ag-LSM/YSZ symmetrical cells at $800{ }^{\circ} \mathrm{C}$

Figure 4.20: Deconvoluted and simulated data for $\mathrm{Ag} /$ organic LSM/HIONIC symmetrical cells at $800{ }^{\circ} \mathrm{C}$

Figure 4.21: Relationship between the oxygen partial pressure and the polarization resistance of a $\mathrm{Ag} /$ organic $\mathrm{LSM} / \mathrm{YSZ}$ symmetrical cell. Polarization resistances recorded from 0.2 atm to $0.002 \mathrm{~atm}$ (down) and from $0.002 \mathrm{~atm}$ to $0.2 \mathrm{~atm}$ (up) at $750{ }^{\circ} \mathrm{C}$ and $800{ }^{\circ} \mathrm{C}$ are shown.

Figure 4.22: Deconvoluted and simulated data for LSM infiltrated YSZ nanofiber scaffold (a) and powder scaffold (b) with LSM current collectors at $800{ }^{\circ} \mathrm{C}$ 111

Figure 4.23: Deconvoluted and simulated data for LSM infiltrated improved YSZ scaffolds (types i and ii) with Ag current collectors at $800{ }^{0} \mathrm{C}$

Figure 5.1: Cole-Cole plot (a) and Negative out of phase impedance vs log frequency plot with equivalent circuit fitting (b) for a LSM/YSZ hybrid cell with Ag current collectors at $800{ }^{0} \mathrm{C} \ldots . .119$

Figure 5.2: Surface and bulk paths for oxygen reduction reaction on a porous cathode

Figure 5.3: Cole-Cole plot (a) and Negative out of phase impedance vs log frequency plot with equivalent circuit fitting (b) for a LSM/YSZ hybrid cell under $2.5 \mathrm{~mA}$ applied current at $800{ }^{\circ} \mathrm{C}$. The solid 
lines in (b) show the contributions of the three elements (RQ1,

RQ2 \& RC) in the equivalent circuit ...................................125

Figure 5.4: Negative out of phase impedance vs log frequency plots for different applied positive voltages at $800{ }^{\circ} \mathrm{C}$ for (a) powder based LSM/YSZ symmetrical cell and (b) solution based LSM/YSZ symmetrical cell

Figure 5.5: (a) Current vs. time plots for Cell A (potentiostatic experiment).

(b) Potential vs. time plots for Cell B (galvanostatic experiment). at $800{ }^{\circ} \mathrm{C}$

Figure 5.6: Fitting parameters of equivalent circuit elements used for impedance data collected for Cell A ((a)-(f)) and Cell B ((g)-(1)) under anodic polarization (LSM paste electrode anode, LSM solution electrode cathode) at $800{ }^{\circ} \mathrm{C}$. Note the sign change on the voltage axes for R3 and Q2 126

Figure 5.7: Variation of resistance (R4) associated with low frequency (gas diffusion arc) with applied voltage for Cell A (a) and Cell B (b). The values are based on an assumed RC equivalent circuit for the gas diffusion process

Figure 5.8: (a) Current vs. time plots for Cell A (potentiostatic experiment).

(b) Potential vs. time plots for Cell B (galvanostatic experiment). at $800{ }^{0} \mathrm{C}$

Figure 5.9: Fitting parameters of equivalent circuit elements used for impedance data collected for Cell A ((a)-(f)) and Cell B ((g)-(l)) under cathodic polarization at $800{ }^{\circ} \mathrm{C}$. Note the positive voltages for R3 and Q2 plots

Figure 5.10: Cole-Cole plot (a) and Negative out of phase impedance vs log frequency plot (b) for a LSM/YSZ hybrid cell under -3.6 mA applied current at $800{ }^{\circ} \mathrm{C}$

Figure 5.11: Cole-Cole plot (a) and Bode plots (b) and (c) showing the slight drift in impedance spectra at low frequencies for Cell A at $0.01 \mathrm{~V}, 800{ }^{0} \mathrm{C}$ 
Figure 5.12: Current-over voltage plots for series resistance (R1), resistance for powder based LSM cathode (R2) and resistance for solution based LSM cathode (R3) of Cell A ((a), (c), (e)) and Cell B ((b), (d), (f)), respectively

Figure 5.13: Resistance of the powder based LSM cathode as a function of the applied voltage for Cell A (a) and Cell B (b) respectively. Resistance values at open circuit voltages OCV 1 (red), OCV 2 (orange), OCV 3 (purple), OCV 4 (black), OCV 5 (blue) and OCV 6 (green) are shown in different colors 


\section{List of Tables}

Table 2.1: Series resistances, polarization resistances and activation energies for Pt containing cells

Table 2.2: Summary of average series resistances and activation energies for conductivity across the cell of Pt containing cells

Table 2.3: Series resistances, polarization resistances and activation energies of $\mathrm{Au}$ containing cells

Table 2.4: Summary of average series resistances and activation energies for conductivity across the cell of Au containing cells.

Table 2.5: Series resistances, polarization resistances and activation energies of Ag containing cells

Table 2.6: Summary of average series resistances and activation energies for conductivity across the cell of Ag containing cells .31

Table 2.7: Series resistances, polarization resistances and activation energies of LSM/YSZ symmetric cells

Table 2.8: Series resistances, polarization resistances and activation energies of YSZ nanofiber cathodes with Pt current collectors

Table 2.9: Series resistances, polarization resistances and activation energies of YSZ nanofiber cathodes with Au current collectors.....43

Table 2.10: Series resistances, polarization resistances and activation energies of YSZ nanofiber cathodes with Ag current collectors...45

Table 2.11: Series and Polarization resistances of YSZ powder cathodes with Ag current collectors.

Table 2.12: Series resistances, polarization resistances and activation energies of LSM infiltrated YSZ cathodes with Ag current collectors .50

Table 3.1: Series resistances, polarization resistances and activation energies for LSM/YSZ symmetrical cells 60

Table 3.2: Series resistances, polarization resistances and activation energies for LSM/YSZ scaffold/YSZ symmetrical cells 
Table 3.3: Series resistances, polarization resistances and activation energies for LSM infiltrated YSZ nanofiber symmetrical cells with 10\% C-LSM current collector

Table 3.4: Series resistances, polarization resistances and activation energies for LSM infiltrated YSZ powder symmetrical cells with 10\% C-LSM current collector

Table 3.5: Series resistances, polarization resistances and activation energies for LSM infiltrated YSZ nanofiber symmetrical cells with pure LSM current collector

Table 3.6: Series resistances, polarization resistances and activation energies for LSM infiltrated YSZ powder symmetrical cells with pure LSM current collector .68

Table 4.1: Summary of results for the sintering study of LSM powder/YSZ symmetrical cells .78

Table 4.2: Normalized fitting parameters for at $800{ }^{\circ} \mathrm{C}$ with (a) $\mathrm{Ag}$ (b) $\mathrm{Pt}$ and (c) Au current collectors for LSM powder/YSZ symmetrical cells 83

Table 4.3: Summary of results for the sintering study of organic LSM solution/YSZ symmetrical cells

Table 4.4: Summary of results for the sintering study of aqueous LSM solution/YSZ symmetrical cells

Table 4.5: Normalized fitting parameters at $800{ }^{\circ} \mathrm{C}$ for $\mathrm{Ag} /$ organic LSM/YSZ symmetrical cell sintered at $900{ }^{0} \mathrm{C}$

Table 4.6: Normalized fitting parameters for $\mathrm{Ag} / \mathrm{YSZ}$ and Pt/YSZ symmetrical cells at $800{ }^{0} \mathrm{C}$. .99

Table 4.7: Normalized fitting parameters for Pt/organic LSM/YSZ and Au/organic LSM/YSZ symmetrical cells at $800{ }^{\circ} \mathrm{C}$. 101

Table 4.8: Normalized fitting parameters at $800{ }^{\circ} \mathrm{C}$ for Ag/organic LSM/YSZ symmetrical cell sintered at $1200{ }^{\circ} \mathrm{C}$

Table 4.9: Normalized fitting parameters for Ag-LSM/YSZ symmetrical cell at $800{ }^{\circ} \mathrm{C}$. 105

Table 4.10: Normalized fitting parameters for Ag/ organic LSM/HIONIC 
symmetrical cell at $800{ }^{\circ} \mathrm{C}$

Table 4.11: Normalized fitting parameters for LSM infiltrated YSZ scaffolds with LSM current collectors at $800{ }^{0} \mathrm{C} \ldots \ldots \ldots \ldots \ldots \ldots \ldots \ldots \ldots \ldots . . . . . . . . . . . . . . . .112$

Table 4.12: Normalized fitting parameters for LSM infiltrated improved YSZ scaffolds with $\mathrm{Ag}$ current collectors at $800{ }^{\circ} \mathrm{C}$. 113

Table 5.1: Summary of results obtained for the temperature study of LSM/YSZ hybrid cells......

Table 5.2: Experimental protocol used for impedance analysis of LSM/YSZ hybrid cells under applied DC voltages (Cell A) and DC currents (Cell B)

Table 5.3: Parameters recorded for Cell A and Cell B at open circuit voltage $\left(800{ }^{0} \mathrm{C}\right)$ 


\author{
Abbreviations \\ CV - Cyclic Voltammetry \\ ECR - Electrochemical Conductivity Relaxation \\ EDS - Energy Dispersive Spectroscopy \\ EIS - Electrochemical Impedance Spectroscopy \\ ESEM - Environmental Scanning Electron Microscope \\ FFT - Fast Fourier Transform \\ FIB-SEM - Focused Ion Beam Scanning Electron Microscope \\ LSM - Lanthanum Strontium Manganite \\ OCV - Open Circuit Voltage \\ ORR - Oxygen Reduction Reaction \\ PAR - Princeton Applied Research \\ $\mathrm{pO}_{2}$ - partial pressure of oxygen \\ SEM - Scanning Electron Microscope \\ SOFC - Solid Oxide Fuel Cell \\ TEC - Thermal Expansion Coefficient \\ TGA - Thermo Gravimetric Analysis \\ TPB - Triple Phase Boundary \\ YSZ - Yttria Stabilized Zirconia \\ WE - Working Electrode \\ XRD - X-Ray Diffractrometry \\ 8YSZ - 8 mol\% Yttria Stabilized Zirconia
}




\section{Chapter 01}

\section{Introduction}

\subsection{Background}

According to the International Energy Outlook 2013 (IEO2013) report released by The Energy Information Administration (EIA), world energy demand will increase by $56 \%$ between 2010 and 2040 and $\sim 80 \%$ of this demand will still need to be fulfilled by fossil fuels [1]. Excessive usage of fossil fuels over years makes the demand vulnerable to scarcity [2]. Furthermore, burning fossil fuels to generate energy result in greenhouse gas emissions which results in global warming [3]. Therefore, it is imperative to construct and use alternative energy sources such as solid oxide fuel cells that efficiently convert simple fuels into electricity without emitting $\mathrm{CO}_{2}$ to the environment.

\subsection{Solid Oxide Fuel Cells}

The solid oxide fuel cell (SOFC) is a device that can be used to directly convert the chemical energy of fuels into electricity with high efficiency and less pollution, in comparison to combustion-based methods [4]. It consists of a porous cathode and a porous anode with a dense solid electrolyte separating the two electrodes. At the cathode (reaction 1.1), oxygen molecules get reduced to oxide $\left(\mathrm{O}^{2-}\right)$ ions using electrons from the external circuit. The solid electrolyte (typically zirconia doped with yttria) conducts $\mathrm{O}^{2-}$ ions at higher temperatures but does not conduct electrons. At the anode (reaction 1.2), $\mathrm{H}_{2}$ fuel gets oxidized to water, forming electrons which flow through the external circuit as the current [4] (Figure 1.1).

Anode: $2 \mathrm{H}_{2}(\mathrm{~g})+2 \mathrm{O}^{2-} \rightarrow 2 \mathrm{H}_{2} \mathrm{O}(\mathrm{g})+4 \mathrm{e}^{-}$

Cathode: $\mathrm{O}_{2}(\mathrm{~g})+4 \mathrm{e}^{-} \rightarrow 2 \mathrm{O}^{2-}$ 


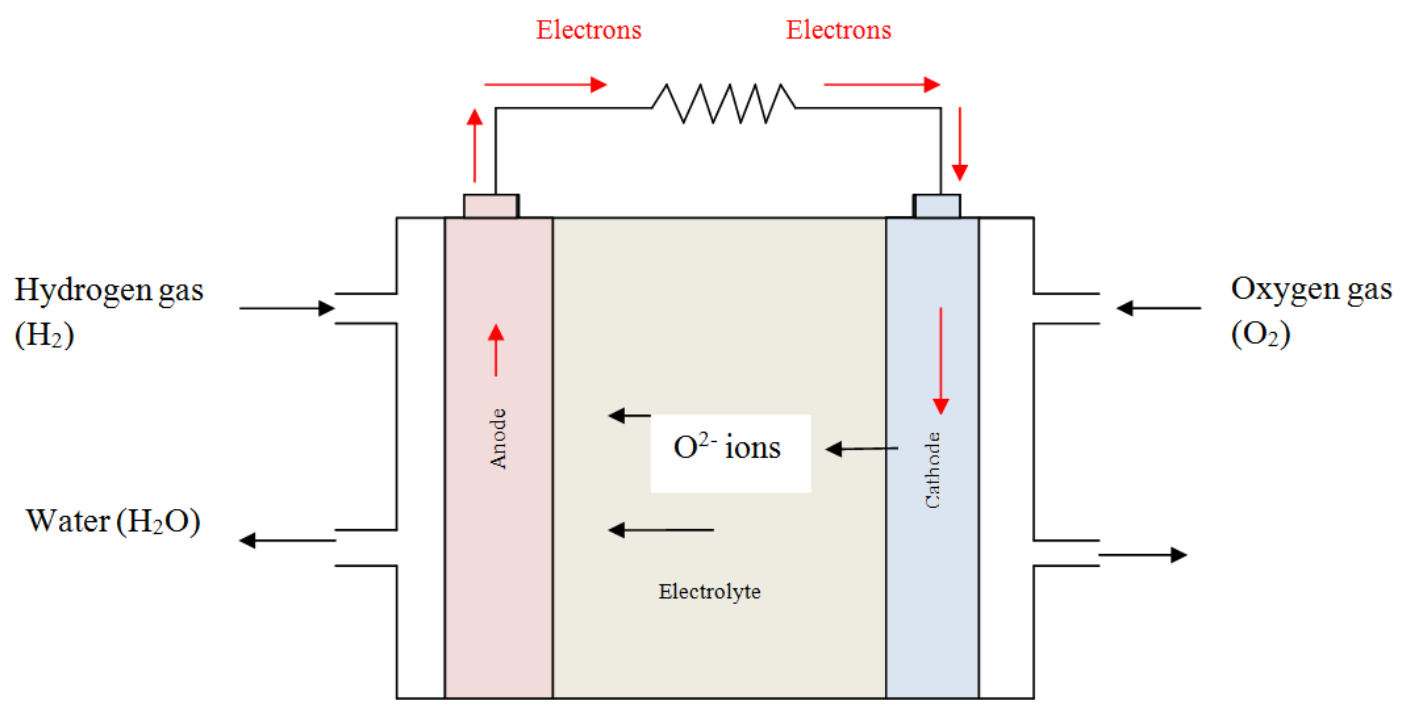

Figure 1.1: Schematic diagram of a Solid Oxide Fuel Cell.

Doped lanthanum gallate, rare earth doped ceria and rare earth doped bismuth oxide are some of the SOFC electrolytes that have been well studied. These SOFC electrolytes are usually oxide ion conductors and the oxide ion conduction is thermally activated. The state of the art electrolyte for high temperature and intermediate temperature SOFCs is Yttria Stabilized Zirconia (YSZ) [5]. Requirements for a suitable SOFC electrolyte are [6]:

i. excellent ionic conductivity and negligible electronic conductivity

ii. stability over a range of temperatures and oxygen partial pressures

iii. compatibility of thermal expansion coefficient with the other cell components

iv. negligible chemical reactions with electrode materials

v. high abundance and low cost

The fuel oxidation takes place on the anode of SOFC. Pt and Ni are some of the anode materials that have been studied over a long time. However, Ni was chosen as the best candidate due to its chemical stability, low cost and catalytic activity towards fuel oxidation. However, Ni alone cannot be used as the anode due to the thermal coefficient mismatch between Ni and YSZ, which results in anode delamination. Therefore, Ni-YSZ 
cermet is used as the state of the art anode in SOFCs. The YSZ phase not only mitigates the thermal expansion mismatch but also prevents the $\mathrm{Ni}$ agglomeration and acts as an oxide ion conductor for the catalytic reaction on Ni. Following are the general requirements for a SOFC anode [6]:

i. chemical and thermal stability

ii. good electronic and ionic conductivity

iii. catalytic activity for fuel oxidation

iv. thermal expansion compatibility with other cell components

v. tolerance to carbon deposition and sulfur poisoning

The most commonly used SOFC cathode material is Strontium doped Lanthanum Manganite $\left(\mathrm{La}_{1-\mathrm{x}} \mathrm{Sr}_{\mathrm{x}} \mathrm{MnO}_{3}\right)$ (LSM). LSM is an $\mathrm{ABO}_{3}$ type perovskite material (orthorhombic phase when $\mathrm{x}=0.2$ ) with high electronic conductivity and low ionic conductivity. Figure 1.2 shows the orthorhombic lattice structure of Lanthanum Manganite $\left(\mathrm{LaMnO}_{3}\right)$ [7]. The electrical conductivity and the catalytic activity of Lanthanum Manganite $\left(\mathrm{LaMnO}_{3}\right)$ increase when it is doped with $\mathrm{Sr}[8]$.

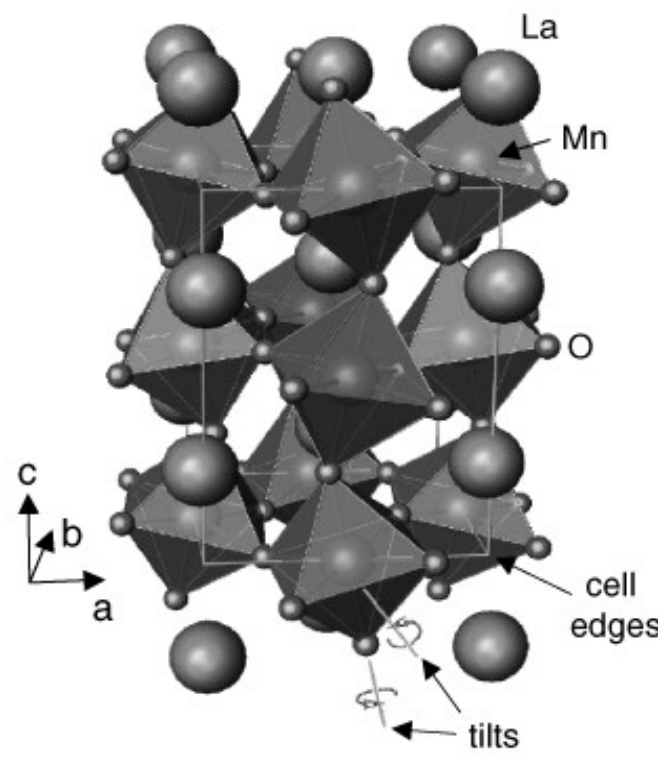

Figure 1.2: Orthorhombic lattice structure of $\mathrm{LaMnO}_{3}[3]$. 
The oxygen reduction reaction of SOFC cathode takes place when oxygen gas, oxide ion vacancies and electrons are present. In other words, the oxygen reduction reaction (Kroger - Vink notation shown in reaction 1.3) occurs only at places where the gas phase, an oxide ion conductor and an electronic conductor meet together. These reaction sites are called Triple phase Boundaries (TPB) (Figure 1.3).

$$
\mathrm{O}_{2}+2 \mathrm{~V}_{\mathrm{O}} \cdot \bullet+4 \mathrm{e}^{-}=2 \mathrm{O}_{\mathrm{o}}^{\mathrm{x}}
$$

$\mathrm{V}_{\mathrm{O}}{ }^{\bullet \bullet}=$ vacant oxygen site, $\mathrm{O}_{\mathrm{o}}{ }^{\mathrm{x}}=$ oxygen ion in YSZ lattice [6].
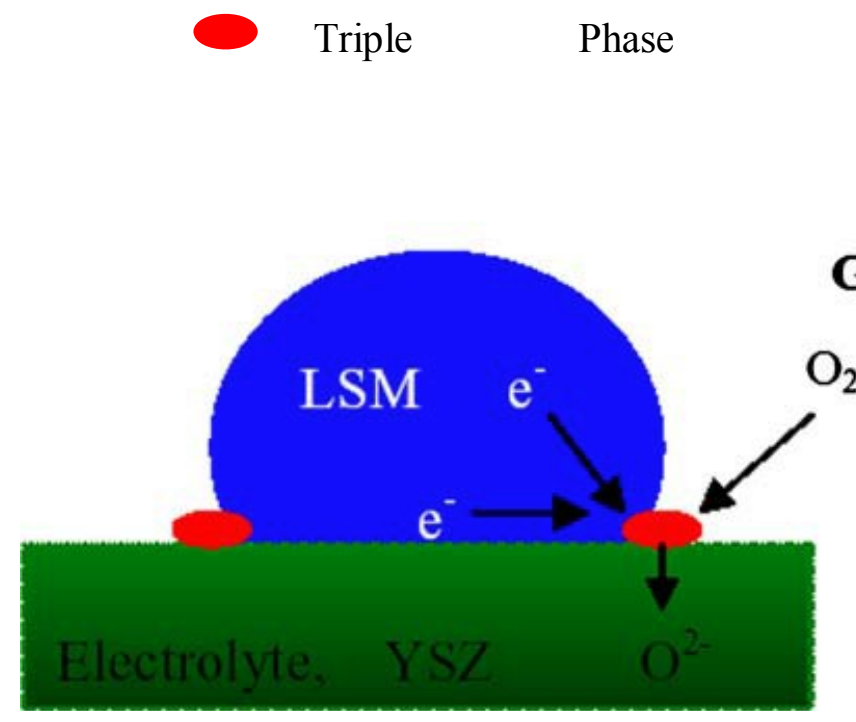

Figure 1.3: Triple Phase Boundary of LSM cathode on YSZ electrolyte [9].

\subsection{Oxygen Reduction Reaction}

Oxygen reduction reaction (ORR) kinetics of SOFC cathodes is widely studied and researchers have proposed different mechanisms with different rate determining steps. However, a well understood exact mechanism for this reaction has yet to be identified [10]. According to Sun et al.'s [9] review paper, the overall oxygen reduction reaction of the SOFC cathode which is (reaction 1.4):

$$
\mathrm{O}_{2} \text { (gas) }+4 \mathrm{e}^{-} \text {(cathode) } \longrightarrow 2 \mathrm{O}^{2-} \text { (electrolyte) }
$$


consists of several elementary steps:

i. adsorption of the $\mathrm{O}_{2}$ molecules

ii. dissociation of $\mathrm{O}_{2}$ molecules

iii. reduction into $\mathrm{O}^{2-}$ anions and incorporation into the cathode material

iv. $\mathrm{O}^{2-}$ ion transport through the cathode to the electrolyte

v. $\mathrm{O}^{2-}$ ion hopping into the electrolyte lattice

Jurgen Fleig [11] has proposed three possible paths (electrode surface path, bulk path and electrolyte surface path (Figure 1.4)) for the cathodic reaction on electron conducting perovskite materials such as LSM. According to Fleig [11], the cathodic reaction of SOFC can simultaneously take place through all three paths.
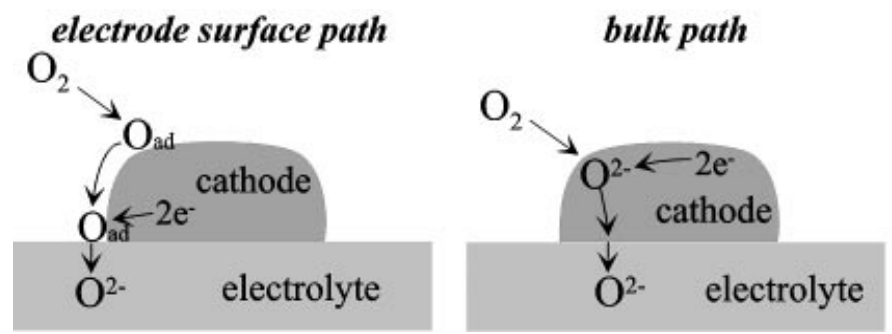

\section{electrolyte surface path}

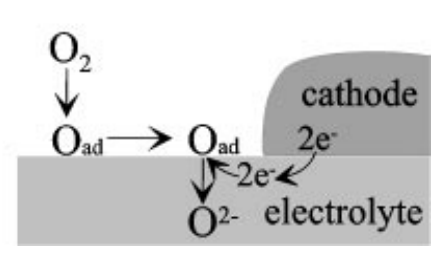

Figure 1.4: Cathodic reaction paths on electron conducting perovskite materials [11].

In the electrode surface path, oxygen gas gets adsorbed on to the cathode and diffuses along the cathode surface to the TPB where the ionization and the oxide ion hopping to the electrolyte occur. In the bulk path, oxygen gas gets adsorbed on to the cathode followed by dissociation and ionization. Then, the oxide ions are transported through the cathode and transferred in to the electrolyte. In the electrolyte surface path, oxygen gas gets adsorbed to the electrolyte surface followed by the ionization using electrons (from the electrolyte). Then, the oxide ions get incorporated into the electrolyte. However, since most electrolytes (eg: YSZ) are poor electron conductors, this reaction takes place in the vicinity of the TPB, making it very similar to the above mentioned electrode surface path [11].

The oxygen reduction reaction of a SOFC has a typical activation energy higher than 1.5 $\mathrm{eV}$ and is the main contributor to the total cell resistance [9], [11]. The rate of the oxygen reduction reaction exponentially decreases with the lower operating temperatures [12]. 
An experimentally accessible quantity, the polarization resistance, is used to characterize the performance of a cathode. The inverse of the polarization resistance is proportional to the rate of the cathode processes. There are various mechanistic contributions to the cathodic polarization resistance $\left(\mathrm{R}_{\text {cathode }}\right)[12]$.

$$
\mathrm{R}_{\text {cathode }}=\mathrm{R}_{\text {gas diffusion }}+\mathrm{R}_{\text {surface adsorption }}+\mathrm{R}_{\text {charge transfer }}+\mathrm{R}_{\text {ohmic }}
$$

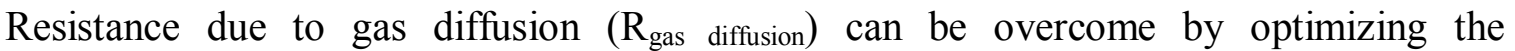
microstructure in order to increase the porosity of the cathode. Resistance due to surface adsorption ( $\mathrm{R}_{\text {surface }}$ adsorption) can be overcome by optimizing the microstructure of the cathode in order to increase the surface area and by increasing the surface diffusivity of the material to increase the kinetics of the oxygen reduction reaction. By increasing the surface area and having continuous charge transfer pathways in the optimized microstructure, and by increasing the kinetics of the oxygen reduction reaction, the resistance due to charge transfer $\left(R_{\text {charge transfer }}\right)$ can be minimized. Also, the Ohmic resistance $\left(R_{\text {ohmic }}\right)$ can be reduced by using a compound with high conductivity and by improving the connectivity of the microstructure [12].

Therefore, there are two approaches to reduce the polarization losses of the cathodes [12]

i. using a compound with high conductivity and improved kinetics for oxygen exchange, diffusion and reduction

ii. optimizing the microstructure of the cathode in order to increase the porosity and to extend the Triple Phase Boundary (TPB) length, or the surface area of the cathode

\subsection{Symmetrical Cells}

Symmetrical cells have the same material on both sides of the electrolyte as overlapping electrodes (Figure 1.5). These cells allow assigning impedance data explicitly to the cathode or anode. However, the impedance data collected for symmetrical cells are only valid at OCV [13]. With applied current, the electrode impedances are no longer identical since one electrode becomes the cathode and the other electrode the anode. 


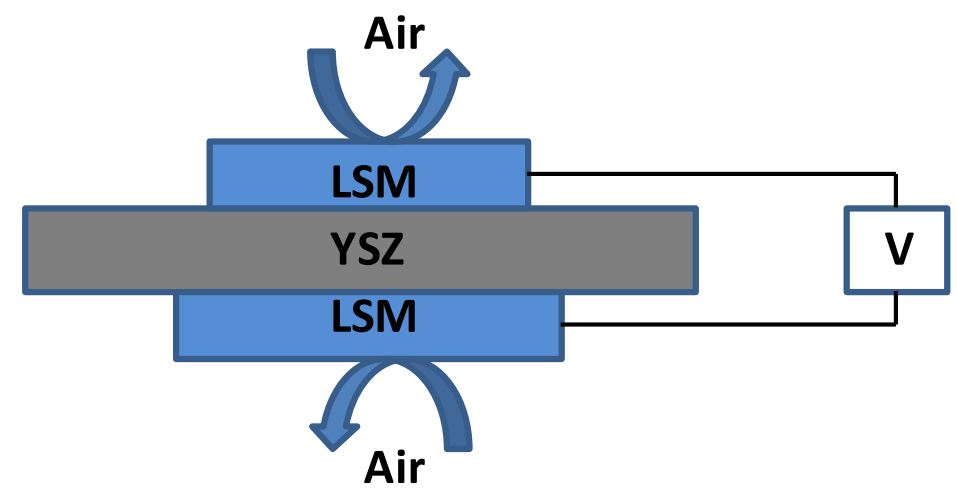

Figure 1.5: Schematic diagram of a LSM/YSZ/LSM symmetrical cell operating in air.

\subsection{Current Collectors}

The current collector is a vital component in SOFCs. It should evenly distribute the current into the cathode and efficiently draw out current from the anode in order to minimize the contact resistance [14]. Also, the current collector should not be involved in any chemical or electrochemical reactions during cell operation [15]. Most commonly used current collectors are metal paste current collectors and metal mesh current collectors.

\subsection{Electrochemical Characterization}

Electrochemical Impedance Spectra (EIS), open circuit voltage (OCV), the power curve (IP curve) and the polarization curve (IV curve) are the main indicators that are used to evaluate the performance of SOFCs [13].

In Electrochemical Impedance Spectroscopy (EIS), an AC voltage is applied to the cell at different frequencies and the resulting AC current is measured. The impedance of the system $(Z)$ can be calculated using an expression analogous to Ohm's law (equation 1.6) [13],[16].

$$
\mathrm{Z}=\frac{\Delta \mathrm{E}_{\mathrm{AC}}}{\mathrm{I}_{\mathrm{AC}}}
$$

The impedance is usually expressed as a complex number with a real part ( $\left.Z^{\prime}\right)$ and an imaginary part (Z"). Impedance data can be plotted in a Nyquist plot (Figure 1.6) in which the $\mathrm{X}-$ axis is real/ in-phase component of impedance $\left(\mathrm{Z}^{\prime}\right)$ and the $\mathrm{Y}$-axis is the negative 
imaginary/out-of-phase component of impedance (-Z"). Each data point of the Nyquist plot represents impedance at a single frequency.

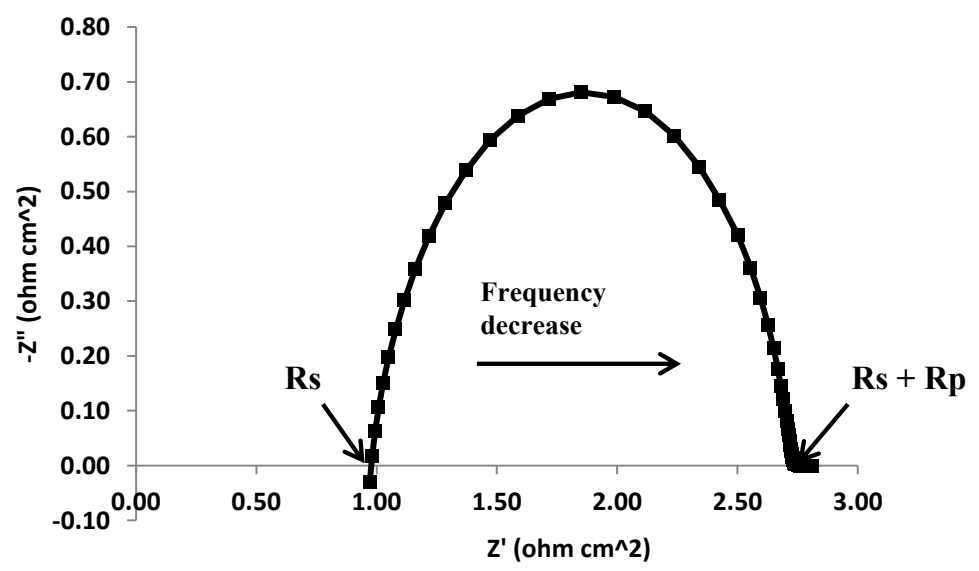

Figure 1.6: Nyquist plot with EIS data.

The high frequency intercept of the plot represents the series resistance $R_{s}$ (the resistance for $\mathrm{O}^{2-}$ ion conductivity across the cell) and the diameter of the arc represents the polarization resistance $\mathrm{R}_{\mathrm{p}}$ (resistance for the oxygen reduction reaction at the cathode). The low frequency intercept represents the total resistance $\left(R_{s}+R_{p}\right)$ of the cell. Furthermore, the impedance of SOFC electrodes can be modeled using equivalent circuits with parameters that have chemical and physical interpretations [16].

The electrical potential difference between two terminals of a device (when there is no external current flow between the terminals) is called the Open Circuit Voltage (OCV) [13] or open circuit potential. The OCV of a typical SOFC operating at $800{ }^{0} \mathrm{C}$ is $\sim 1.1 \mathrm{~V}$ [15] and OCV for a symmetrical cell is $0 \mathrm{~V}$.

In the polarization curve (Figure 1.7), the $\mathrm{Y}$ - axis represents the cell voltage while the $\mathrm{X}$ axis represents the current. Cell voltage decreases with the increasing current. In the power curve, the Y-axis represents the power (voltage*current) while the $\mathrm{X}$ - axis represents the current. The peak power density of the SOFC according to this plot is $\sim 0.8 \mathrm{Wcm}^{-2}$. 


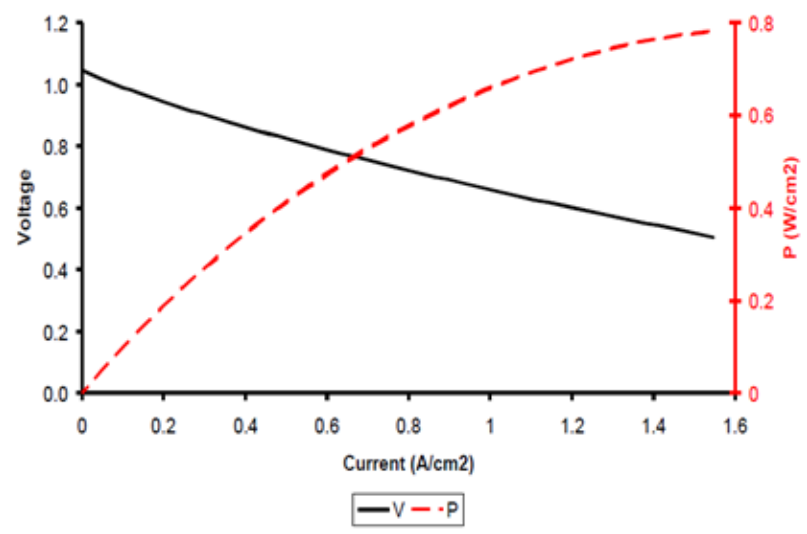

Figure 1.7: The polarization curve (black) and the power curve (red) for a single SOFC [13].

\subsection{Equivalent circuit elements and electrochemical processes}

Characterization of SOFCs using impedance spectroscopy yields useful yet complex data due to overlapping impedance related processes. Ivers-Tiffee [17] developed a method called "deconvolution" (distribution of relaxation times) in order to identify important relaxation times that are relevant to cell processes, using the impedance data. A well detailed discussion on deconvolution method is presented in Xiaoke Chen's [13] Ph.D. dissertation. In order to perform the deconvolution, impedance data are fitted to a mathematical expression that is derived from the Voigt's circuit (equation 1.7).

$$
\mathrm{Z}_{(\omega)}=\mathrm{R}_{0}+\mathrm{R}_{\mathrm{p}} \Sigma \mathrm{g}_{\mathrm{k}} /\left(1+\mathrm{j} \omega \tau_{\mathrm{k}}\right)
$$

Where " $\mathrm{Z}_{(\omega)}$ " is impedance data, " $\mathrm{R}_{0}$ " is series resistance, " $\mathrm{R}_{\mathrm{p}}$ " is polarization resistance, " $\mathrm{g}_{\mathrm{k}}$ " is fraction of $\mathrm{R}_{\mathrm{p}}$ in an element at a particular frequency, " $\tau_{\mathrm{k}}$ " is the time constant for the process.

If the data obey Karamers -Kronig transformation, only the out of phase impedance (Z") can be used for data fitting. The first step is the removal of the inductance from the impedance data. Then, Fast Fourier Transform (FFT) will be applied to the Z" vs. frequency data in order to get the $Z_{n}$ (fourier transform of Z") and $S_{n}$ (fourier transform of hyperbolic secant function. Dividing each $Z_{n}$ by the corresponding $S_{n}$ results in fourier 
coefficients of $G_{n}$. After that, a filter function will be applied to remove noise and inverse FFT on $G_{n}$ coeffients will be performed in order to get the deconvoluted spectrum [13] (Figure $1.8(b)$ ).

Deconvolution process sharpens the impedance features and hence reveals the processes that are not readily visible in a Bode plot (Figure 1.8).
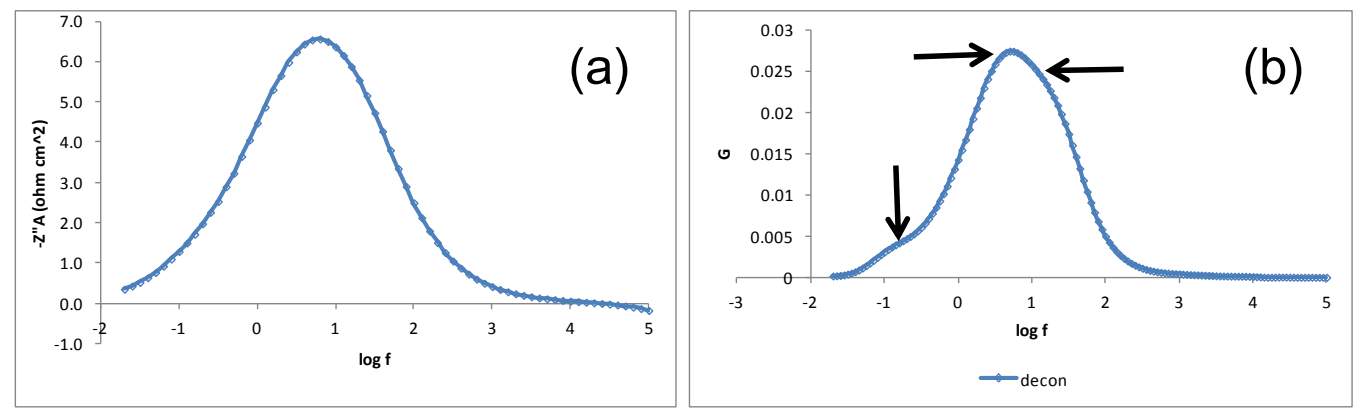

Figure 1.8: A Bode plot (a) and the corresponding deconvoluted spectrum (b) which reveals the peaks/shoulders for three possible impedance processes.

The information obtained through deconvolution of impedance data is very important for proposing suitable equivalent circuit models (which usually consist of a series of arc forming elements shown below [18]), which in turn helps to calculate the polarization resistances at each electrode.

\section{i. $\quad$ Parallel RC element (RC)}

This element represents charge transfer at the electrode/electrolyte interface. The $\mathrm{R}$ value is inversely related to the rate of the process which determines the current. The capacitance $\mathrm{C}$ can either be the interfacial capacitance of the electrode/ electrolyte interface (often called the double layer capacitance) or the chemical capacitance associated with the mechanism for charge transfer.

The chemical capacitance can be interpreted as proportional to the moles of species undergoing an oxidation state change in the mechanism. Chemical capacitances can be much larger than double layer capacitances in SOFCs.

The chemical capacitance $\mathrm{C}$ is related to the charge available at the electrode/electrolyte interface. If $\mathrm{Q}_{\text {total }}=$ charge available in $\mathrm{C} / \mathrm{cm}^{2}$, then 


$$
\mathrm{C}=\mathrm{Q}_{\mathrm{total}} /(4 \mathrm{RT} / \mathrm{F})
$$

Where $\mathrm{R}=$ Ideal Gas Constant, $\mathrm{T}=$ temperature in $\mathrm{K}$, and $\mathrm{F}=$ Faraday's constant.

For surface species with coverage $\Gamma$ in $\mathrm{mol} / \mathrm{cm}^{2}$,

$$
\mathrm{Q}_{\text {total }}=\mathrm{F} \Gamma
$$

For bulk species, let $\mathrm{A}$ be the moles of redox active species per $\mathrm{cm}^{3}$, and let $\mathrm{f}$ be the volume of species in $\mathrm{cm}^{3}$ covering the electrolyte area in $\mathrm{cm}^{2}\left(\mathrm{f}=\mathrm{cm}^{3} / \mathrm{cm}^{2}\right)$. Then

$$
\Gamma=\operatorname{Af}
$$

This simple equivalent circuit implies that the electrode/electrolyte interface occupies a single well defined plane with identical electrolyte resistance to all parts of the electrode and identical rates of reaction and capacitances.

$$
\mathrm{Z}=\mathrm{R} /(1+\mathrm{T}(\mathrm{j} \omega))
$$

$\mathrm{R}=$ polarization resistance

$\mathrm{T}=$ time constant $=\mathrm{R} * \mathrm{C}$

And $\omega=2 \pi \mathrm{f}=$ radial frequency

\section{ii. Parallel RQ element (RQ)}

This element is similar to the (RC) element except that the properties or rates associated with $\mathrm{R}$ and $\mathrm{C}$ are now distributed. $\mathrm{Q}$ is called a constant phase element since it exhibits a constant phase angle at all frequencies. The admittance for the $\mathrm{Q}$ element is:

$$
\mathrm{Y}=\mathrm{Q}(\mathrm{j} \omega)^{\mathrm{U}}
$$

Hence,

$$
\begin{gathered}
\mathrm{Z}=\mathrm{R} /\left(1+\mathrm{T}(\mathrm{j} \omega)^{\mathrm{U}}\right) \\
\mathrm{T}=\mathrm{RQ}
\end{gathered}
$$


This element collapses to the parallel RC element when the exponent $U=1$. Typically $U$ is less than 1. Then $\mathrm{Q}$ is no longer a capacitance, and $\mathrm{T}$ is no longer a time constant.
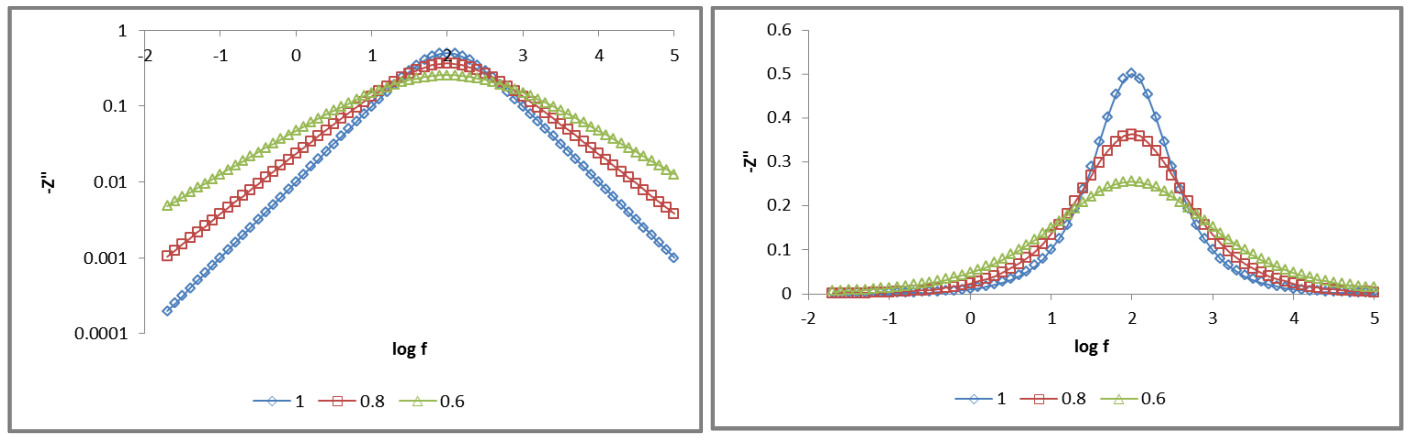

Figure 1.9: Bode plots (-Z" vs log f): (RC) and (RQ) elements with varying exponent U values shown. The arc is symmetrical in the left plot. In the double log plot, the magnitudes of the slopes of the lines away from the peak frequency are equal to the $U$ value [18].

\section{iii. Gerischer element $(\mathrm{Ge})$}

The Gerischer element arises for two situations. For a SOFC electrode composed of a mixed ionic electronic conductor, this element appears in the impedance spectrum as the result of two simultaneous processes, the reaction of the gas with the electrode throughout the electrode structure, and mass transfer of the reaction products to the electrode/electrolyte interface. The Gerischer element also describes the impedance response of a porous electrode with the pores filled with electrolyte (Figure 1.9 [19]). The de Levie analysis [20] represents the porous structure as a series of cylindrical pores perpendicular to the electrode/electrolyte plane. The system behaves like a transmission line. In the limit of infinitely long pores, Gerischer behavior is obtained.

$$
Z=R /(1+T(j \omega))^{P}
$$

$\mathrm{P}=0.5$ for a Gerischer element. A single fractal Gerischer element allows $\mathrm{P}$ to deviate from 0.5 . The interpretation of $\mathrm{T}$ depends on the mechanism. 


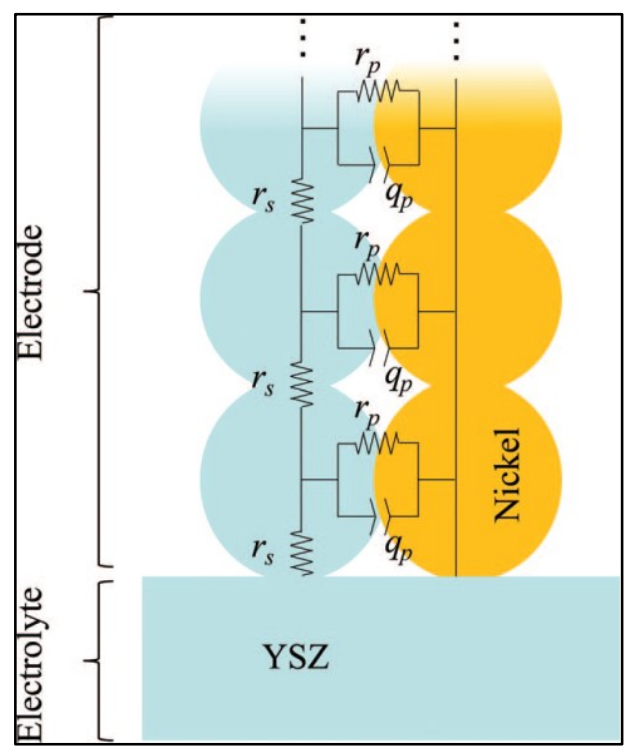

Figure 1.10: Representing a porous electrode as a series of cylindrical pores [19].
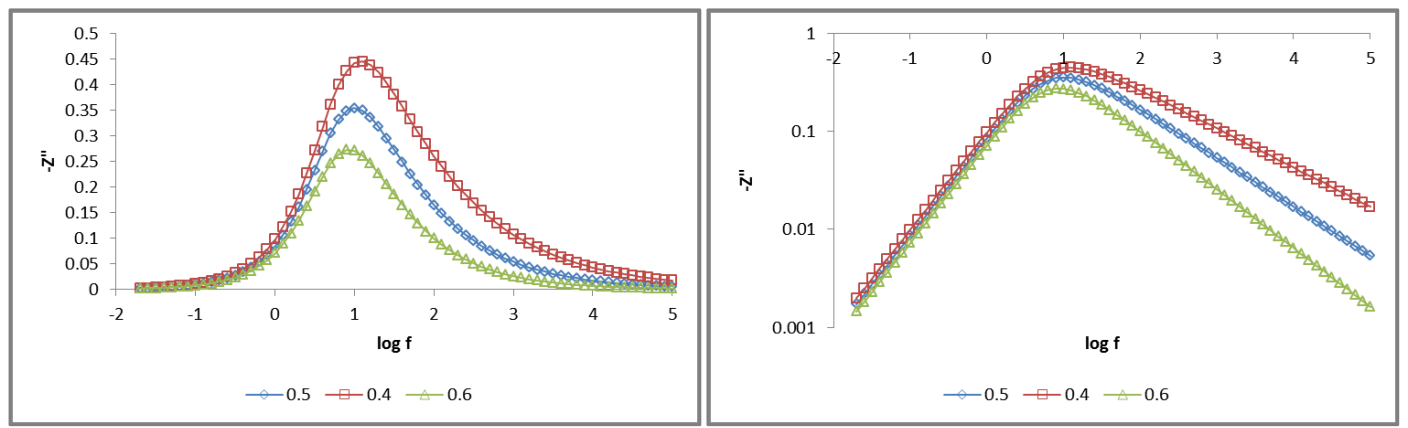

Figure 1.11: Fractal Gerischer element with varying $\mathrm{P}$ values. The Bode plot is asymmetrical with a long tail on the high frequency side. The double log plot shows that the slope on the low frequency side is 1 and the magnitude of the slope on the high frequency side is $\mathrm{P}$ [18].

\section{iv. Havriliak-Negami element $(\mathrm{HN})$}

Because many properties are distributed, a real SOFC electrode exhibits behavior that does not fit the true Gerischer element or the single fractal Gerischer element. The HavriliakNegami element (aka the double fractal Gerischer element) allows both exponents to adopt a range of values.

$$
Z=R /\left(1+T(j \omega)^{U}\right)^{P}
$$



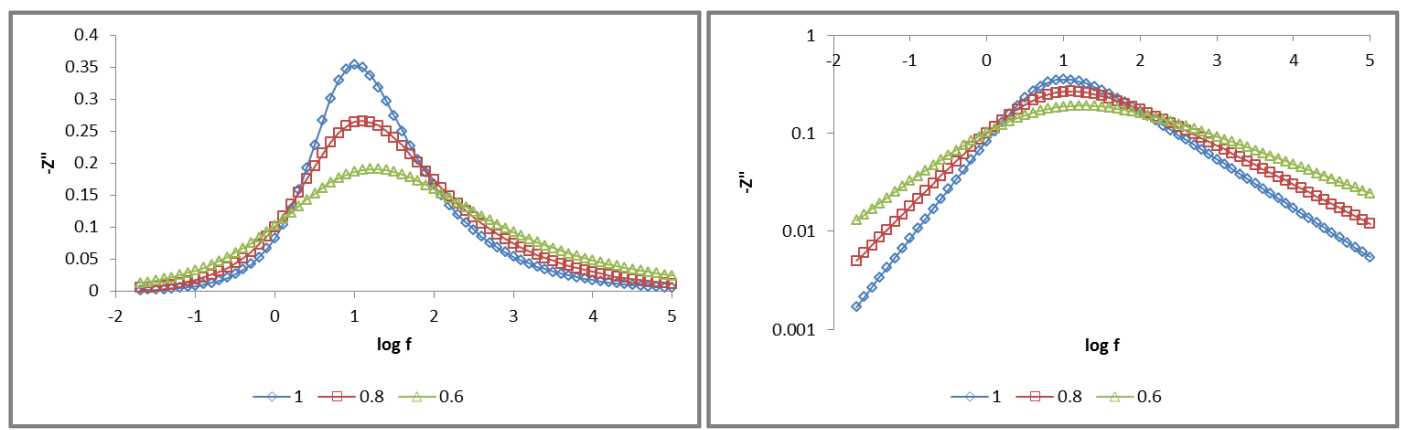

Figure 1.12: $\mathrm{HN}$ element with $\mathrm{P}=0.5$ and varying $\mathrm{U}$ values. The Bode plot is again asymmetrical with a long tail on the high frequency side. The magnitude of the slope of the $\log \log$ plot approaches $\mathrm{U}$ on the low frequency side and $\mathrm{P} * \mathrm{U}$ on the high frequency side [18].

\section{v. Warburg impedance (W)}

The Warburg impedance appears when mass transfer by diffusion is controlling the impedance. For a SOFC, the presence of convective gas flow outside the electrodes usually means that diffusion is the dominant form of mass transfer only inside the porous electrode. Diffusion over a fixed length leads to the finite length Warburg element.

$$
\begin{gathered}
Z=R * \tanh (u) / u \\
u=(j \omega T)^{n}
\end{gathered}
$$

$\mathrm{R}$ is the diffusion resistance. Ideally, the exponent $\mathrm{n}=0.5$, but a generalized finite length Warburg (FLW) allows deviation of the exponent from $1 / 2$. The $\mathrm{T}$ parameter equals $l 2 / \mathrm{D}$, where $l$ is the finite diffusion length, and $\mathrm{D}$ is the diffusion coefficient of the reactant.

\subsection{Challenges for Solid Oxide Fuel Cells}

The high operating temperature $\left(800{ }^{0} \mathrm{C}-1000{ }^{0} \mathrm{C}\right)$ is the major disadvantage of SOFCs since it results in slow start up time, fast cell degradation and requirement for more expensive materials such as ceramic interconnects [8]. Therefore, there is a high interest to reduce the operating temperature of SOFCs. However, when the operating temperature of SOFC is decreased, rates of electrochemical reactions drop exponentially; especially the cathode reactions which have high activation energies and low reaction kinetics compared to the anode reactions. This in turn decreases the overall cell performance [8]. Therefore, it 
is imperative to develop SOFC cathodes that are best performing in intermediate temperatures $\left(600{ }^{\circ} \mathrm{C}-800{ }^{\circ} \mathrm{C}\right)$ either by improving the microstructure and/or by developing high performance materials.

On the other hand, improvement of microstructure needs fundamental understanding of the reaction processes associated with the cathode that can be learned using impedance spectroscopy [17]. However, in order to extract useful information, it is important to use methods that can separate different processes associated with different cell components, especially under applied DC voltages/currents.

\subsection{Objectives and the Structure of the Dissertation}

As mentioned above, development of better performing cathodes are very important for the advancement of intermediate temperature solid oxide fuel cells. Therefore, one objective of this research is to develop SOFC cathodes with improved microstructures which in turn would result in better performance at intermediate temperatures. The other objective is to study different processes associated with different cell components (with minimal effect from each other) in order to better understand the processes associated with cell reactions.

Choosing a suitable current collector is very important for SOFC characterization. Therefore, current collection properties of noble metals $(\mathrm{Pt}, \mathrm{Au}$ and $\mathrm{Ag}$ ) and LSM were investigated using the Princeton Applied Research (PAR) system and the results are discussed in Chapter 02 - Section I. Preliminary studies carried out on YSZ nanofiber cathodes using the PAR system are discussed in Chapter 02 - Section II. Chapter 03 discusses the results obtained using the Solartron system for LSM infiltrated YSZ cathodes with LSM current collectors. Impedance spectroscopy data of different SOFC cathodes (LSM, Ag-LSM, LSM-YSZ) and their deconvolution analysis are discussed in Chapter 04. Chapter 05 discusses the possibility of studying a single electrode with DC current flow using LSM/YSZ "hybrid" cells. 


\subsection{References}

1. International Energy Outlook 2013, DOE/EIA-0484(2013), July 2013 http://www.eia.gov/forecasts/ieo/pdf/0484\%282013\%29.pdf (07/15/2014)

2. How Fuel Cells Work, http://auto.howstuffworks.com/fuel-efficiency/alternativefuels/fuel-cell.htm/printable (07/15/2014)

3. Climate change: Basic information, http://www.epa.gov/climatechange/basics/ $(07 / 15 / 2014)$

4. Zuo C., Liu M., Liu M., Chapter 2 - Solid Oxide Fuel Cells, Sol-Gel Processing for Conventional and Alternative Energy, Advances in Sol-Gel Derived Materials and Technology (Editor: Lisa Klein), Springer Science, NY, 2012, ISBN 978-14614-1956-3; e-SBN 978-1-4614-1957-0; DOI 10.1007/978-1-4614-1957-0

5. $\quad$ Singhal S.C., Prepr. Pap. American Chemical Society, 2004, 49 (2), 478 - 479 https://web.anl.gov/PCS/acsfuel/preprint\%20archive/Files/49_2_Philadelphia_1004_1013.pdf(08/11/2014)

6. $\quad$ Fergus J.W., Hui R., Li X., Wilkinson D.P., Zhang J., Solid Oxide Fuel Cells Material Properties and Performance, CRC press, 2009, ISBN 978-1-4200-88830

7. Geck J., Wochner P., Kiele S., Klingeler R., Revcolevschi A., Zimmermann M., Büchner B., Reutler P., New Journal of Physics, 2004, 6, 152, 1-28

8. Jiang S.P., Journal of Materials Science, 2008, 43, 6799-6833.

9. Sun C., Hui R., Roller J., Journal of Solid State Electrochemistry, 2010, 14, 1125 $-1144$

10. Adler S.B., Chemical Reviews, 2004, 104, 4791- 4843

11. Fleig J., Annual Review of Materials Research, 2003, 33, 361 - 382

12. Wachsman E.D., Armstrong E.N., Electrochemical Society Transactions, 2011, $35,1955-1963$

13. Chen X., Aging Effects of the Cathode and Determination of Single Electrode Performance in a Solid Oxide Fuel Cell, Dissertation, West Virginia University, 2013 
14. Guo Y., Liu Y., Cai R., Chen D., Ran R., Shao Z., International journal of Hydrogen Energy, 2012, 37, 14492 - 14500

15. Guillodo M., Vernoux P., Fouletier J., Solid State Ionics, 2000, 127, 99 - 107

16. Finklea H., Notes on Electrochemical Impedance Spectroscopy, West Virginia University, 2010-2014

17. Schichlein H., Muller A., Voigts M., Krugel A., Ivers-Tiffee E., Journal of Applied Electrochemistry, 2002, 32, 875 - 882

18. Finklea H., Notes on Equivalent circuit elements and electrochemical processes, West Virginia University, 2014

19. Jensen S., Hauch A., Knibbe R., Jacobsen T., Mogensen M., Journal of the Electrochemical Society, 2013, 160(3), F244-F250

20. Orazem M., Tribollet B., Electrochemical Impedance Spectroscopy, The Electrochemical Society Series, John Wiley \& Sons, 2008 , pp. 252-255. 


\section{Chapter 02}

\section{Section I}

\section{Metal and LSM Current Collectors}

\subsection{Introduction}

Current collector properties are vital for the solid oxide fuel cell (SOFC) performance since the resistance due to contact materials results in Ohmic losses. Noble metals (Pt, Pd, $\mathrm{Au}$, $\mathrm{Ag})$ and some ceramic materials $\left(\mathrm{CaCoO}_{3}, \mathrm{LaCrO}_{3}\right)$ are commonly used as current collectors in high temperature SOFCs. High costs associated with noble metal current collectors ( $\mathrm{Pt}, \mathrm{Au}, \mathrm{Pd}$ ) make them less desirable to be used in large scale even though they are very stable at high operating temperatures. Ceramic current collectors have higher stability in oxidizing conditions which makes them good candidates for cathode current collection but the low electrical conductivity limits their desirability [1].

The main goal of this study was to compare the current collection properties of platinum $(\mathrm{Pt})$, gold $(\mathrm{Au})$, silver $(\mathrm{Ag})$ and Lanthanum Strontium Manganite (LSM) on Yttria Stabilized Zirconia (YSZ) electrolyte. Moreover, their performance as SOFC cathodes was also studied by measuring the polarization resistances.

Commercially bought YSZ disks ( 8 mol\% yttria) from Fuel Cell Materials (diameter $=20$ $\mathrm{mm}$, thickness $=0.3 \mathrm{~mm}$ ) were used as the electrolytes for our experiments. As reported in literature [2], the activation energy for conductivity across $8 \mathrm{YSZ}$ ( $8 \mathrm{~mol} \%$ yttria stabilized zirconia) is around $0.91 \mathrm{eV}$ at $850{ }^{\circ} \mathrm{C}-1000{ }^{\circ} \mathrm{C}$ and $1.10 \mathrm{eV}$ at $400{ }^{\circ} \mathrm{C}-500{ }^{\circ} \mathrm{C}$.

The main problem we had to face was the delamination of metal current collectors (especially $\mathrm{Pt}$ and $\mathrm{Au}$ ) from the YSZ electrolyte. Therefore, we tried roughening the electrolyte surface by sand papering or by screen printing an additional YSZ layer. Furthermore, we used $\mathrm{Bi}_{2} \mathrm{O}_{3}$, a well-known sintering aid in order to improve the adhesion of metal current collectors to YSZ electrolyte. In order to do this, a thin layer $(\sim 0.05 \mathrm{~mL})$ of $\mathrm{Bi}\left(\mathrm{NO}_{3}\right)_{3}$ solution $(0.27 \mathrm{M})$ was deposited on $\mathrm{YSZ}$ and sintered at $800{ }^{\circ} \mathrm{C}$ to get the $\mathrm{Bi}_{2} \mathrm{O}_{3^{-}}$ 
modified YSZ surface. Also, a $\mathrm{Bi}_{2} \mathrm{O}_{3}$ powder was prepared by thermal oxidation of $\mathrm{Bi}\left(\mathrm{NO}_{3}\right)_{3}$ at $700{ }^{0} \mathrm{C}$, and this powder was mixed with the metal pastes to achieve good adhesion to the YSZ electrolyte.

\subsection{Experimental}

Current collection properties of the chosen metals and LSM were studied by the electrochemical characterization of symmetrical cells. The symmetrical cells (preparation methods will be discussed later) were characterized using the Princeton Applied Research (PAR) system from $850{ }^{0} \mathrm{C}$ (or $800{ }^{\circ} \mathrm{C}$ ) to $700{ }^{\circ} \mathrm{C}$ in air by Cyclic Voltammetry (CV) and Electrochemical Impedance Spectroscopy (EIS). For CV measurements, a Potentiostat (EG \& G instruments- Model 283) with a Digitizing Oscilloscope (Tektronix-TDS 430 A) and a Universal Programmer (EG\& G instruments- Model 175) was used while the Potentiostat (EG \& G instruments- Model 283) and a Lock -in Amplifier (EG \& G instruments- 7220 DSP) was used for EIS measurements.

Figure 2.1 shows how the symmetrical cell was mounted for the electrochemical characterization. The cell was kept inside the tube furnace with the aid of a quartz cell holder. One of the $\mathrm{Ag} / \mathrm{Au}$ wires coming out of the furnace were connected to the working and sense leads while the other wire was connected to the reference and counter leads of the potentiostat.

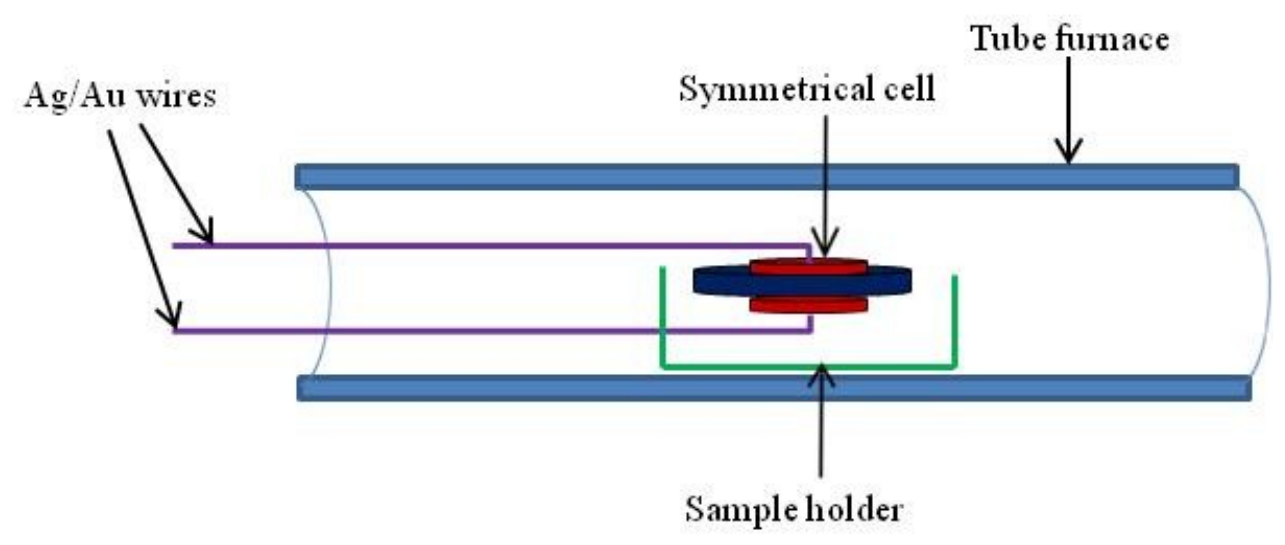

Figure 2.1: Cross section of the tube furnace when the cell is mounted. 
The total resistance of the cell can be obtained using CV data. EIS data provide the series resistance (the resistance for oxide ion conductivity across the cell plus the resistance of the wires and current collector contacts). From the difference between the total resistance and the series resistance, the polarization resistance (resistance for the oxygen reduction reaction at the cathode) can be obtained.

\subsubsection{Cyclic Voltammetry Measurements}

In order to do CV measurements, the symmetric cell was connected to the potentiostat and the voltage was swept from $0 \mathrm{~V}$ to a negative cell voltage, then to a positive cell voltage and back to $0 \mathrm{~V}$; while recording the current. Then, the reciprocal slope of the voltammogram (Figure 2.2) was used to obtain the total cell resistance.

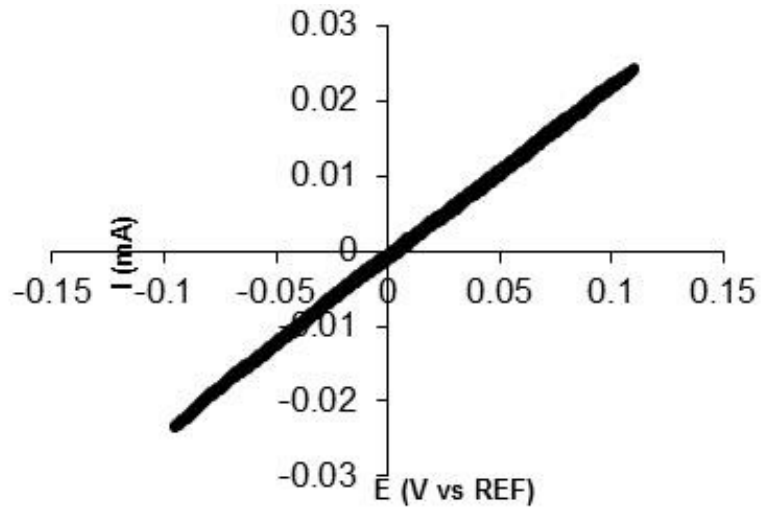

Figure 2.2: Voltammogram for a $\mathrm{Pt} / Y S Z$ nanofiber/YSZ symmetrical cell $(\mathrm{d}=4 \mathrm{~mm})$ at $700^{\circ} \mathrm{C}$. The total resistance calculated by the reciprocal slope of the line is $4.36 \mathrm{kOhms}$.

\subsubsection{Electrochemical Impedance Spectroscopy Measurements}

In our EIS experiments, a Potentiostat (EG \& G instruments- Model 283) and a Lock -in Amplifier (EG \& G instruments- 7220 DSP) was used to make the measurements at frequencies 10, 2050 and $100 \mathrm{kHz}$. Due to instrument limitations, only four measurements at four different frequencies were manually collected and a straight line was obtained in the high frequency region instead of an arc. This high frequency intercept was recorded as our series resistance $\mathrm{R}_{\mathrm{s}}$. Figure 2.3 is an example of a plot that was obtained for EIS data. 


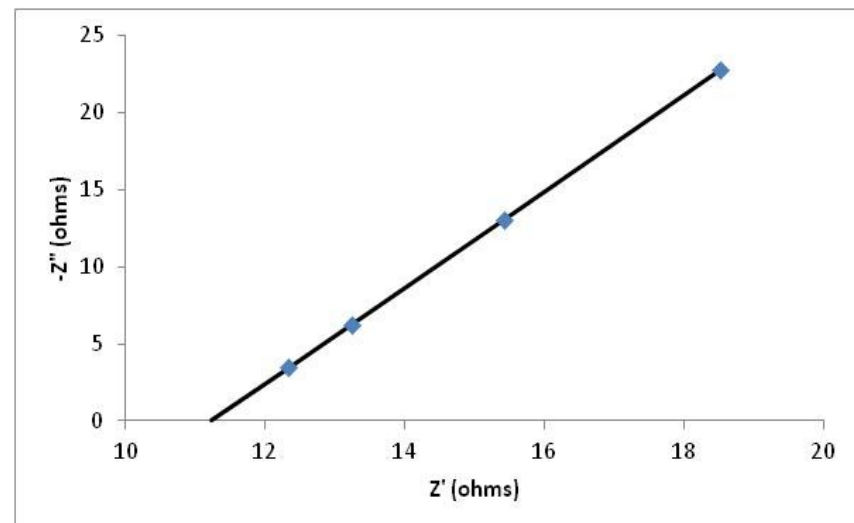

Figure 2.3: A plot of EIS data for a Pt/Roughened YSZ/Pt symmetric cell at $700^{\circ} \mathrm{C}$. The series resistance obtained by the high frequency intercept is 11.2 Ohms.

By repeating the $\mathrm{CV}$ and EIS measurements in a range of temperatures, the activation energy for the oxygen reduction reaction of the cathode and the activation energy for the conductivity across the cell can be found by the Arrhenius plots. The slope of the Arrhenius plot can be multiplied by the gas constant $\left(8.314 \mathrm{JK}^{-1} \mathrm{~mol}^{-1}\right)$ and divided by Faraday's constant $\left(96485 \mathrm{Cmol}^{-1}\right)$ to achieve the activation energy in electron volts $(\mathrm{eV})$. Figures 2.4 and 2.5 show an example of the Arrhenius plots for a Pt/roughened YSZ symmetrical cell characterized at $700{ }^{\circ} \mathrm{C}, 750{ }^{\circ} \mathrm{C}, 800{ }^{\circ} \mathrm{C}$ and $850{ }^{\circ} \mathrm{C}$.

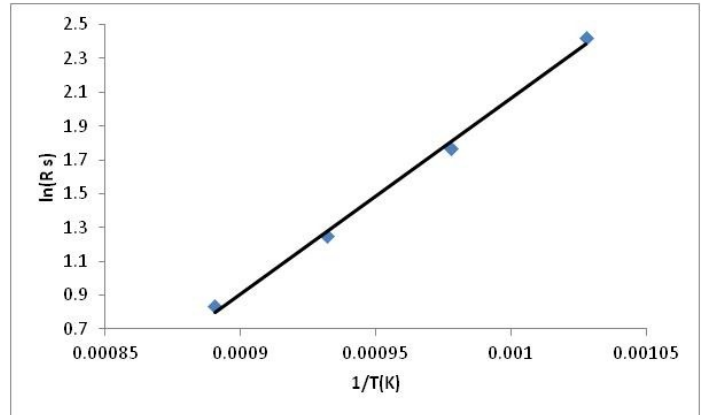

Figure 2.4: Arrhenius plot for the series resistance $\left(R_{s}\right)$ and the deduced activation energy for the oxide ion conductivity across the cell. Slope $=$ 11565+/- 453, Intercept $=-9.5+/-0.4$, $\mathrm{R}^{2}=0.997, \mathrm{E}_{\mathrm{a}}=1.00+/-0.04 \mathrm{eV}$.

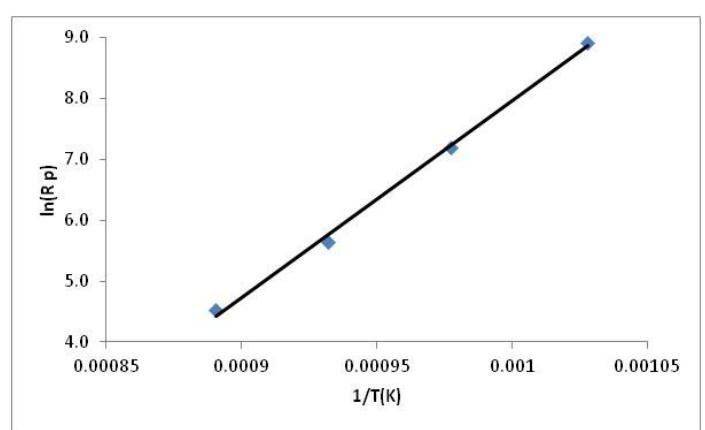

Figure 2.5: Arrhenius plot for the polarization resistance $\left(R_{p}\right)$ and the deduced activation energy for the oxygen reduction reaction at the cathode. Slope $=32300+/-1173$, Intercept $=-24+/-1, \mathrm{R}^{2}=0.997, \mathrm{E}_{\mathrm{a}}=$ $2.8+/-0.1 \mathrm{eV}$. 


\subsection{Platinum (Pt)}

\subsubsection{Introduction}

Platinum is a pure electronic conductor [1] and the oxygen reduction on $\mathrm{Pt}$ is a reaction that has been well studied over a long time [3]. Also, because of its stability at temperatures up to $1000{ }^{\circ} \mathrm{C}$, Pt mesh is a commonly used current collector in SOFCs [4].

\subsubsection{Sample Preparation}

Different symmetrical cells (5) listed below were prepared using pure Pt paste (SPI$\mathrm{CHEM})$ on bare/roughened/ $\mathrm{Bi}_{2} \mathrm{O}_{3}$-modified YSZ electrolytes, $\mathrm{Pt}$ and $\mathrm{YSZ}$ mixture $(0.4 \mathrm{~g}$ Pt paste with 0.1 g YSZ powder (Fuel Cell Materials YSZ8-TC)) on bare YSZ electrolyte and $\mathrm{Pt}$ paste and $\mathrm{Bi}_{2} \mathrm{O}_{3}$ powder mixture (1:1 by weight) on bare YSZ electrolytes.

i. Pt/bare YSZ: Pt electrodes were painted on bare YSZ electrolyte surface and sintered at $1100{ }^{0} \mathrm{C}$ or $850{ }^{\circ} \mathrm{C}$.

ii. Pt/roughened YSZ: The YSZ electrolyte surface was modified by screen-printing a thin, additional YSZ layer followed by sintering at $1300{ }^{\circ} \mathrm{C}$ (in order to enhance the adhesion of the Pt layer). Then, Pt electrodes were painted on roughened YSZ surface and sintered at $900{ }^{\circ} \mathrm{C}$.

iii. Pt - YSZ/YSZ: Pt paint and YSZ powder was mixed together to form a paste which was painted on bare YSZ and sintered at $1100{ }^{\circ} \mathrm{C}$.

iv. $\mathrm{Pt} / \mathrm{Bi}_{2} \mathrm{O}_{3}-\mathrm{YSZ}$ : Pt electrodes were painted on $\mathrm{Bi}_{2} \mathrm{O}_{3}$-deposited YSZ substrates and sintered at $1100{ }^{\circ} \mathrm{C}$ or $850{ }^{\circ} \mathrm{C}$.

v. $\quad \mathrm{Pt}-\mathrm{Bi}_{2} \mathrm{O}_{3} / Y S Z$ : Pt paint and $\mathrm{Bi}_{2} \mathrm{O}_{3}$ powder was mixed together to form a paste which was painted on bare YSZ and sintered at $850{ }^{\circ} \mathrm{C}$.

\subsubsection{Electrochemical Characterization}

These symmetrical cells were electrochemically characterized by $\mathrm{CV}$ and EIS at $850{ }^{0} \mathrm{C}$,

$800{ }^{\circ} \mathrm{C}, 750{ }^{\circ} \mathrm{C}$ and $700{ }^{\circ} \mathrm{C}$ using $\mathrm{Au}$ wires and Au paste. Some cells were aged at $700{ }^{0} \mathrm{C}$ for a certain time period and the electrochemical characterization was repeated at the above mentioned temperatures. 


\subsubsection{Results and Discussion}

Note: When the same cell was re-characterized/aged, it is shown with a prime ('). Calculated activation energies and only the resistances measured at $800{ }^{\circ} \mathrm{C}$ are presented in tables so that the resistances at the other temperatures can be calculated.

Table 2.1: Series resistances, polarization resistances and activation energies for Pt containing cells.

\begin{tabular}{|c|c|c|c|c|c|}
\hline Sample & Description & $\begin{array}{c}\mathbf{R}_{\mathrm{s}} \\
\left(\mathrm{Ohmcm}^{2}\right) \\
\text { at } 800^{\circ} \mathrm{C}\end{array}$ & $\begin{array}{l}E_{a}(e V) \\
\text { for } R_{s}\end{array}$ & $\begin{array}{c}\mathbf{R}_{\mathrm{p}} \\
\left(\mathrm{Ohmcm}^{2}\right) \\
\text { at } 800^{0} \mathrm{C}\end{array}$ & $\begin{array}{l}E_{a}(e V) \\
\text { for } R_{p}\end{array}$ \\
\hline i (a) & $\mathrm{Pt} /$ bare YSZ sintered at $1100{ }^{\circ} \mathrm{C}$ & 1.21 & $\begin{array}{c}0.6 \\
(+/-0.0)\end{array}$ & 18.27 & $\begin{array}{c}2.6 \\
(+/-0.1) \\
(+0)\end{array}$ \\
\hline $\mathrm{i}(\mathrm{a})^{\prime}$ & $\begin{array}{l}\mathrm{Pt} / \text { bare YSZ sintered at } 1100{ }^{0} \mathrm{C} \\
(\sim 48 \mathrm{hrs} \text { aged }) / \mathrm{Au} \text { current collector }\end{array}$ & 1.22 & $\begin{array}{c}0.6 \\
(+/-0.0)\end{array}$ & 255.5 & $\begin{array}{c}1.9 \\
(+/-0.1)\end{array}$ \\
\hline i (b) & Pt/bare YSZ (sintered at $850{ }^{\circ} \mathrm{C}$ ) & 1.03 & $\begin{array}{c}1.0 \\
(+/-0.0)\end{array}$ & 2.41 & $\begin{array}{c}2.3 \\
(+/ 0.2)\end{array}$ \\
\hline ii (a) & $\mathrm{Pt} /$ roughened YSZ, sintered at $900^{\circ} \mathrm{C}$ & 1.06 & $\begin{array}{c}1.1 \\
(+/-0.0)\end{array}$ & 19.9 & $\begin{array}{c}2.3 \\
(+/ 0.1)\end{array}$ \\
\hline ii (b) & Pt/roughened YSZ, sintered at $900{ }^{\circ} \mathrm{C}$ & 0.74 & $\begin{array}{c}1.0 \\
(+/-0.1)\end{array}$ & 9.4 & $\begin{array}{c}1.9 \\
(+/-0.1)\end{array}$ \\
\hline ii (c) & $\mathrm{Pt} /$ roughened YSZ, sintered at $900{ }^{\circ} \mathrm{C}$ & 1.12 & $\begin{array}{c}1.0 \\
(+/-0.0)\end{array}$ & 45.7 & $\begin{array}{c}2.8 \\
(+/-0.1)\end{array}$ \\
\hline ii (c)' & $\begin{array}{l}\text { Pt/roughened YSZ, sintered at } 900{ }^{\circ} \mathrm{C} \\
(\sim 96 \mathrm{hrs} \text { aged })\end{array}$ & 1.00 & $\begin{array}{c}0.6 \\
(+/-0.1)\end{array}$ & 20.09 & $\begin{array}{c}2.5 \\
(+/-0.0)\end{array}$ \\
\hline iii & $\begin{array}{l}\text { Pt-YSZ/YSZ, sintered at } \\
{ }^{0} \mathrm{C} / \mathrm{Au} \text { current collector }\end{array}$ & 1.79 & $\begin{array}{c}0.7 \\
(+/-0.0)\end{array}$ & 3.97 & $\begin{array}{c}1.3 \\
(+/ 0.0)\end{array}$ \\
\hline iv (a) & $\begin{array}{l}\mathrm{Pt} / \mathrm{Bi}_{2} \mathrm{O}_{3}-\mathrm{YSZ}, \mathrm{Bi}\left(\mathrm{NO}_{3}\right)_{3} \text { sintered at } \\
850^{\circ} \mathrm{C} \text {, Pt sintered at } 850^{\circ} \mathrm{C}\end{array}$ & 0.71 & $\begin{array}{c}0.8 \\
(+/-0.0)\end{array}$ & 0.41 & $\begin{array}{c}2.1 \\
(+/-0.1)\end{array}$ \\
\hline iv (b) & $\begin{array}{l}\mathrm{Pt} / \mathrm{Bi}_{2} \mathrm{O}_{3}-\mathrm{YSZ}, \mathrm{Bi}\left(\mathrm{NO}_{3}\right)_{3} \text { sintered at } \\
850^{\circ} \mathrm{C} \text {, Pt sintered at } 850^{\circ} \mathrm{C}\end{array}$ & 0.91 & $\begin{array}{c}1.03 \\
(+/ 0.0)\end{array}$ & 1.31 & $\begin{array}{c}2.9 \\
(+/-0.1)\end{array}$ \\
\hline $\operatorname{iv}(\mathrm{c})$ & $\begin{array}{l}\mathrm{Pt} / \mathrm{Bi}_{2} \mathrm{O}_{3}-\mathrm{YSZ}, \mathrm{Bi}\left(\mathrm{NO}_{3}\right)_{3} \text { sintered at } \\
8500^{\circ} \mathrm{C} \text {, Pt sintered at } 1100{ }^{\circ} \mathrm{C}\end{array}$ & 0.98 & $\begin{array}{c}0.98 \\
(+/ 0.0)\end{array}$ & 4.93 & $\begin{array}{c}2.3 \\
(+/-0.2)\end{array}$ \\
\hline v (a) & $\mathrm{Pt}-\mathrm{Bi}_{2} \mathrm{O}_{3} / \mathrm{YSZ}$, sintered at $850{ }^{\circ} \mathrm{C}$ & 1.24 & $\begin{array}{c}1.2 \\
(+/-0.0)\end{array}$ & 1.13 & $\begin{array}{c}2.4 \\
(+/-0.1)\end{array}$ \\
\hline $\mathrm{v}(\mathrm{a})^{\prime}$ & $\begin{array}{l}\mathrm{Pt}-\mathrm{Bi}_{2} \mathrm{O}_{3} / \mathrm{YSZ}, \text { sintered at } \\
850{ }^{0} \mathrm{C} \text {, re-characterization of } \mathrm{v}(\mathrm{a})\end{array}$ & 0.88 & $\begin{array}{c}0.9 \\
(+/ 0.0)\end{array}$ & 0.81 & $\begin{array}{c}1.8 \\
(+/-0.2)\end{array}$ \\
\hline $\mathrm{v}(\mathrm{b})$ & $\mathrm{Pt}-\mathrm{Bi}_{2} \mathrm{O}_{3} / \mathrm{YSZ}$, sintered at $850{ }^{\circ} \mathrm{C}$ & 2.47 & $\begin{array}{c}1.0 \\
(+/ 0.0)\end{array}$ & 5.72 & $\begin{array}{c}2.3 \\
(+/-0.1)\end{array}$ \\
\hline $\mathrm{v}(\mathrm{b})^{\prime}$ & $\begin{array}{l}\mathrm{Pt}-\mathrm{Bi}_{2} \mathrm{O}_{3} / \mathrm{YSZ}, \text { sintered at } \\
850{ }^{\circ} \mathrm{C} \text {, re-characterization of } \mathrm{v}(\mathrm{b})\end{array}$ & 1.51 & $\begin{array}{c}0.9 \\
(+/ 0.0)\end{array}$ & 3.59 & $\begin{array}{c}2.2 \\
(+/-0.1)\end{array}$ \\
\hline
\end{tabular}

Table 2.1 present the series and polarization resistances measured at $800{ }^{\circ} \mathrm{C}$ and the corresponding activation energies for Pt containing cells. A summary of average series resistances and corresponding activation energies for Pt containing cells are presented in 
Table 2.2. When Student's t-test was used for statistical analysis [5], there was no statistically significant difference between the average $R_{s}$ values for samples (i) and (ii) which suggests that the adhesion of Pt to YSZ substrate was similar in both cases. Furthermore, since their average $\mathrm{R}_{\mathrm{s}}$ values are higher than expected $\left(>0.7 \mathrm{Ohmcm}^{2}\right.$ at 800 ${ }^{0} \mathrm{C}$ ), it can be concluded that the bare or roughened YSZ surfaces did not promote the adhesion of the Pt layer. There is a 95\% confident significant difference between the average $\mathrm{R}_{\mathrm{s}}$ values for samples (i) and (iv) due to $\mathrm{Bi}_{2} \mathrm{O}_{3}$. Sample (iv) yielded the most consistent $R_{\mathrm{s}}$ values and consequently appears to be the best method for obtaining a good bond between YSZ and Pt paint. There is no significant difference between the average activation energies $\left(E_{a}\right)$ for samples (i) and (ii) or (i) and (iv).

Barbucci et al. [6] reports the $\mathrm{R}_{\mathrm{s}}$ value at $900{ }^{\circ} \mathrm{C}$ for their Pt/YSZ system as $\sim 1.0 \mathrm{Ohmcm}^{2}$ which is slightly higher than our results. However, this is a property that depends on the thickness of the YSZ substrate and differs from one batch/manufacturer to another.

Table 2.2: Summary of average series resistances and activation energies for conductivity across the cell of Pt containing cells.

\begin{tabular}{|c|c|c|c|c|}
\hline Sample & $\begin{array}{c}\text { Average } \mathbf{R}_{\mathbf{s}} \text { at } \\
\mathbf{8 0 0}^{\mathbf{0}} \mathbf{C} \\
\left(\mathbf{O h m c m}^{\mathbf{2}}\right)\end{array}$ & $\begin{array}{c}\text { Standard } \\
\text { deviation }\end{array}$ & $\begin{array}{c}\text { Average } \mathbf{E}_{\mathbf{a}} \text { for } \\
\mathbf{R}_{\mathbf{s}} \mathbf{( e V )}\end{array}$ & $\begin{array}{c}\text { Standard } \\
\text { deviation }\end{array}$ \\
\hline (i) & 1.15 & $+/-0.1$ & 0.73 & $+/-0.2$ \\
\hline (ii) & 0.98 & $+/-0.2$ & 0.93 & $+/-0.2$ \\
\hline (iii) & 1.79 & - & 0.70 & $+/-0.0$ \\
\hline (iv) & 0.87 & $+/-0.1$ & 0.94 & $+/-0.1$ \\
\hline (v) & 1.53 & $+/-0.7$ & 1.01 & $+/-0.1$ \\
\hline
\end{tabular}

Badwal [7] has reported resistivity values ranging from $\sim 25-36 \mathrm{Ohmcm}$ for $8 \mathrm{YSZ}$ at 800 ${ }^{0} \mathrm{C}$, while the resistivity value calculated for our $8 \mathrm{YSZ}$ electrolytes is also $\sim 25 \mathrm{Ohmcm}$ at $800{ }^{0} \mathrm{C}$.

The polarization resistances of Pt electrodes drastically decreased when bismuth oxide was used as a sintering aid. However, sample iv(c) has a comparatively high $R_{p}$ value. Furthermore, it can be seen that the performance of Pt electrodes was comparatively 
enhanced when they were sintered at $850{ }^{\circ} \mathrm{C}$, compared to the electrodes sintered at 1100 ${ }^{0} \mathrm{C}$. Possibly high temperature sintering causes agglomeration of the Pt particles which would reduce the porosity and the oxygen availability for the oxygen reduction reaction which in turn results in higher $R_{p}$ values. Also, it is known that Pt tends to volatilize at higher temperatures and to be deposited at the cathode/electrolyte surface which decrease the cell performance [4]. Furthermore, when a gold current collector was used on Pt, the $\mathrm{R}_{\mathrm{p}}$ values increased drastically.

Barbucci et al. [6] performed a similar experiment with a 3-electrode system where the working electrodes (WE) was sintered at $1100{ }^{\circ} \mathrm{C}$ for 2 hours and then characterized at 900 ${ }^{0} \mathrm{C}$. They reported a $\mathrm{R}_{\mathrm{p}}$ value of $4.76 \mathrm{Ohmcm}^{2}$ for pure Pt WE and $1.5 \mathrm{Ohmcm}^{2}$ for a WE that consists of a mixture of Pt and YSZ. These results are comparable to some values that we have obtained for pure Pt (eg: samples (i)a, (ii)a and (ii)b) and also it was observed that the $R_{p}$ values decrease when a mixture of Pt and YSZ is used as the WE (sample iii). The lowest $\mathrm{R}_{\mathrm{p}}$ values were obtained when $\mathrm{Bi}_{2} \mathrm{O}_{3}$ was used in Pt electrodes. Verkerk et al. [8] have reported their results of a similar study where they characterized sputtered $\mathrm{Pt}$ electrodes on $\mathrm{YSZ}$ and $\mathrm{Bi}_{2} \mathrm{O}_{3}-\mathrm{Er}_{2} \mathrm{O}_{3}$. They observed that both the $\mathrm{R}_{\mathrm{s}}$ and $\mathrm{R}_{\mathrm{p}}$ values significantly decreased when Bi modified electrolytes were used. This is not surprising as $\mathrm{Bi}_{2} \mathrm{O}_{3}$ is a very good oxide ion conductor at high temperatures with a conductivity that is $\sim 2$ times higher than YSZ [2]. Due to high ionic conductivity of $\mathrm{Bi}_{2} \mathrm{O}_{3}$ and its ability to sinter Pt well onto the YSZ electrolyte, $\mathrm{R}_{\mathrm{s}}$ values become smaller (e.g., Sample iv (a)). Also, having $\mathrm{Pt}$ (pure electronic conductor) and $\mathrm{Bi}_{2} \mathrm{O}_{3}$ (oxide ion conductor) together with the gas phase increases the triple phase boundary (TPB) length; resulting in lower $R_{p}$ values (e.g., Sample iv (a)).

Vladikova et al.[9] have reported the activation energy for oxygen reduction reaction on $\mathrm{Pt} / \mathrm{YSZ}$ electrodes (for temperatures above $600{ }^{\circ} \mathrm{C}$ ) as $1.6 \mathrm{eV}$. However, the activation energy values that we have observed for the oxygen reduction reaction are relatively higher than this value. 


\subsubsection{Summary}

Pt electrodes delaminating from the YSZ electrolyte was the most significant issue while characterizing Pt containing symmetrical cells. Typical $\mathrm{R}_{\mathrm{s}}$ value for these YSZ electrolytes at $800{ }^{\circ} \mathrm{C}$ is $\sim 0.7 \mathrm{Ohmcm}^{2}$. However, according to Table 2.1 , only 2 cells (ii (b) and iv (a)) showed $\mathrm{R}_{\mathrm{S}}$ values in this range and one of them had $\mathrm{Bi}_{2} \mathrm{O}_{3}$ as a sintering aid. Some compositions (eg: iv (a)) exhibited both very low $R_{p}$ and $R_{s}$ values which suggest that these compositions would be good candidates as a SOFC cathode material.

\subsection{Gold (Au)}

\subsubsection{Introduction}

Gold $(\mathrm{Au})$ is known to be a better current collector than Pt due to its lower mobility and inertness [4]. However, it is reported to be a poor SOFC cathode due to its low catalytic activity for oxygen reduction [10], [11]. Similar to $\mathrm{Pt}$, the oxygen reduction reaction is limited to triple phase boundaries in Au cathodes [4], [12].

\subsubsection{Sample Preparation}

Different symmetrical cells (4) listed below were prepared using pure Au paste (Heraeus) on bare/roughened/ $\mathrm{Bi}_{2} \mathrm{O}_{3}$-modified YSZ electrolytes and $\mathrm{Au}$ paste and $\mathrm{Bi}_{2} \mathrm{O}_{3}$ powder mixture (1:1 by weight) on bare YSZ electrolytes.

i. Au/bare YSZ: Au electrodes were painted on bare YSZ electrolyte surface and sintered at $900{ }^{0} \mathrm{C}$ or $850{ }^{0} \mathrm{C}$.

ii. Au/roughened YSZ: YSZ electrolyte surface was modified by screen printing a thin, additional YSZ layer followed by sintering at $1300{ }^{\circ} \mathrm{C}$ (in order to enhance the adhesion of the (Au layer). Then, Au electrodes were painted on roughened YSZ surface and sintered at $900{ }^{\circ} \mathrm{C}$.

iii. $\mathrm{Au} / \mathrm{Bi}_{2} \mathrm{O}_{3}-\mathrm{YSZ}$ : $\mathrm{Au}$ electrodes were painted on $\mathrm{Bi}_{2} \mathrm{O}_{3}$ deposited YSZ substrates and sintered at $700{ }^{0} \mathrm{C}$ or $850{ }^{\circ} \mathrm{C}$.

iv. $\mathrm{Au}-\mathrm{Bi}_{2} \mathrm{O}_{3} / \mathrm{YSZ}$ : $\mathrm{Au}$ paint and $\mathrm{Bi}_{2} \mathrm{O}_{3}$ powder was mixed together to form a paste which was painted on bare YSZ and sintered at $850{ }^{\circ} \mathrm{C}$. 


\subsubsection{Electrochemical Characterization}

These symmetrical cells were electrochemically characterized by CV and EIS at $850{ }^{\circ} \mathrm{C}$, $800{ }^{\circ} \mathrm{C}, 750{ }^{\circ} \mathrm{C}$ and $700{ }^{\circ} \mathrm{C}$ using Au wires and Au paste.

\subsubsection{Results and Discussion}

Note: When the same cell was re-characterized/aged, it is shown with a (') or (") or ("), and further details are given in the table. Calculated activation energies and only the resistances measured at $800{ }^{\circ} \mathrm{C}$ are presented in tables so that the resistances at the other temperatures can be calculated.

Table 2.3: Series resistances, polarization resistances and activation energies of Au containing cells.

\begin{tabular}{|c|c|c|c|c|c|}
\hline Sample & Description & $\begin{array}{c}R_{\mathrm{s}} \\
\left(\mathrm{Ohmcm}^{2}\right) \\
\text { at } 800^{\circ} \mathrm{C} \\
\end{array}$ & $\begin{array}{l}E_{a}(e V) \\
\text { for } R_{s}\end{array}$ & $\begin{array}{c}R_{\mathrm{p}} \\
\left(\mathrm{Ohmcm}^{2}\right) \\
\text { at } 800^{\circ} \mathrm{C} \\
\end{array}$ & $\begin{array}{l}E_{a}(e V) \\
\text { for } R_{p}\end{array}$ \\
\hline i (a) & $\mathrm{Au} /$ bare $\mathrm{YSZ}$ sintered at $900{ }^{\circ} \mathrm{C}$ & 0.66 & $\begin{array}{c}0.8 \\
(+/-0.0)\end{array}$ & 414 & $\begin{array}{c}1.6 \\
(+/-0.1)\end{array}$ \\
\hline $\mathrm{i}(\mathrm{b})$ & $\mathrm{Au} /$ bare YSZ sintered at $850{ }^{\circ} \mathrm{C}$ & 0.72 & $\begin{array}{c}0.8 \\
(+/-0.1)\end{array}$ & 8.2 & $\begin{array}{c}1.3 \\
(+/-0.2)\end{array}$ \\
\hline ii (a) & $\begin{array}{l}\text { Au/roughened YSZ, sintered at } \\
900{ }^{\circ} \mathrm{C}\end{array}$ & 1.47 & $\begin{array}{c}1.0 \\
(+/-0.0)\end{array}$ & 519 & $\begin{array}{c}1.2 \\
(+/-0.1)\end{array}$ \\
\hline ii (b) & $\begin{array}{l}\text { Au/roughened YSZ, sintered at } \\
900{ }^{0} \mathrm{C}\end{array}$ & 4.22 & $\begin{array}{c}0.9 \\
(+/-0.1)\end{array}$ & 2203 & $\begin{array}{c}1.7 \\
(+/-0.0)\end{array}$ \\
\hline iii (a) & $\begin{array}{l}\mathrm{Au} / \mathrm{Bi}_{2} \mathrm{O}_{3}-\mathrm{YSZ}, \mathrm{Bi}\left(\mathrm{NO}_{3}\right)_{3} \\
\text { sintered at } 850{ }^{\circ} \mathrm{C} \text {, Au sintered at } \\
850{ }^{\circ} \mathrm{C}\end{array}$ & 0.62 & $\begin{array}{c}0.9 \\
(+/-0.0)\end{array}$ & 2.2 & $\begin{array}{c}1.7 \\
(+/-0.1)\end{array}$ \\
\hline iii (b) & $\begin{array}{l}\mathrm{Au} / \mathrm{Bi}_{2} \mathrm{O}_{3}-\mathrm{YSZ}, \mathrm{Bi}\left(\mathrm{NO}_{3}\right)_{3} \\
\text { sintered at } 850{ }^{\circ} \mathrm{C} \text {, Au sintered at } \\
850{ }^{\circ} \mathrm{C}\end{array}$ & 0.77 & $\begin{array}{c}0.8 \\
(+/-0.1)\end{array}$ & 3.6 & $\begin{array}{c}1.2 \\
(+/-0.0)\end{array}$ \\
\hline iii (c) & $\begin{array}{l}\mathrm{Au} / \mathrm{Bi}_{2} \mathrm{O}_{3}-\mathrm{YSZ}, \mathrm{Bi}\left(\mathrm{NO}_{3}\right)_{3} \text { and } \\
\mathrm{Au} \text { sintered at } 850^{\circ} \mathrm{C}\end{array}$ & 0.64 & $\begin{array}{c}0.9 \\
(+/-0.1)\end{array}$ & 5.5 & $\begin{array}{c}1.6 \\
(+/-0.1)\end{array}$ \\
\hline iii (d) & $\begin{array}{l}\mathrm{Au} / \mathrm{Bi}_{2} \mathrm{O}_{3}-\mathrm{YSZ}, \mathrm{Bi}\left(\mathrm{NO}_{3}\right)_{3} \text { and } \\
\mathrm{Au} \text { sintered at } 700{ }^{\circ} \mathrm{C}\end{array}$ & 1.14 & $\begin{array}{c}0.8 \\
(+/-0.0)\end{array}$ & 3.9 & $\begin{array}{c}1.3 \\
(+/-0.1)\end{array}$ \\
\hline iii (e) & $\begin{array}{l}\mathrm{Au} / \mathrm{Bi}_{2} \mathrm{O}_{3}-\mathrm{YSZ}, \mathrm{Bi}\left(\mathrm{NO}_{3}\right)_{3} \\
\text { sintered at } 1100{ }^{\circ} \mathrm{C}, \mathrm{Au} \text { sintered } \\
\text { at } 850{ }^{\circ} \mathrm{C}\end{array}$ & 1.02 & $\begin{array}{c}1.1 \\
(+/-0.0)\end{array}$ & 4.5 & $\begin{array}{c}1.8 \\
(+/-0.0)\end{array}$ \\
\hline iv & $\begin{array}{l}\mathrm{Au}-\mathrm{Bi}_{2} \mathrm{O}_{3} / \mathrm{YSZ} \text {, sintered at } \\
850^{\circ} \mathrm{C}\end{array}$ & 0.72 & $\begin{array}{c}0.8 \\
(+/-0.1)\end{array}$ & 0.46 & $\begin{array}{c}1.1 \\
(+/-0.0)\end{array}$ \\
\hline
\end{tabular}


Table 2.4: Summary of average series resistances and activation energies for conductivity across the cell of Au containing cells.

\begin{tabular}{|c|c|c|c|c|}
\hline Sample & $\begin{array}{c}\text { Average } \mathbf{R}_{\mathbf{s}} \text { at } \\
\mathbf{8 0 0}^{\mathbf{0}} \mathbf{C} \\
\left(\mathbf{O h m c m}^{\mathbf{2}}\right)\end{array}$ & $\begin{array}{c}\text { Standard } \\
\text { deviation }\end{array}$ & $\begin{array}{c}\text { Average } \mathbf{E}_{\mathbf{a}} \text { for } \\
\mathbf{R}_{\mathbf{s}}(\mathbf{e V})\end{array}$ & $\begin{array}{c}\text { Standard } \\
\text { deviation }\end{array}$ \\
\hline (i) & 0.7 & $+/-0.0$ & 0.8 & $+/-0.0$ \\
\hline (ii) & 2.9 & $+/-2.0$ & 1.0 & $+/-0.1$ \\
\hline (iii) & 0.9 & $+/-0.2$ & 0.9 & $+/-0.1$ \\
\hline (iv) & 0.7 & - & 0.8 & - \\
\hline
\end{tabular}

According to Tables 2.3 and 2.4, very high $R_{\mathrm{s}}$ values for sample (ii) suggest that Au was not completely sintered on roughened YSZ electrolytes. Similar to Pt, the lowest $R_{s}$ and $R_{p}$ values were observed when $\mathrm{Bi}_{2} \mathrm{O}_{3}$ was incorporated into $\mathrm{Au}$ electrodes. Samples (i) and (iv) show the typical series resistance for these YSZ electrolytes at $800{ }^{0} \mathrm{C}\left(\sim 0.7 \mathrm{Ohmcm}^{2}\right)$, which confirms that there was no electrode delamination while the electrochemical characterization was carried out. Furthermore, Vladikova et al. [9] have reported the activation energy for oxygen reduction reaction on $\mathrm{Au} / \mathrm{YSZ}$ (for temperatures below 450 ${ }^{0} \mathrm{C}$ ) as $1.0 \mathrm{eV}$. Since our measurements were carried out in $700{ }^{0} \mathrm{C}-850{ }^{0} \mathrm{C}$ temperature range, it limits the direct comparison of activation energy values.

\subsubsection{Summary}

As same as with Pt, delamination of Au electrodes from the YSZ electrolytes was the major obstacle. However, when $\mathrm{Bi}_{2} \mathrm{O}_{3}$ was used as a sintering aid, low $\mathrm{R}_{\mathrm{s}}$ values were achieved (most of the time), which suggests good adhesion. Also, very low $R_{p}$ and $R_{s}$ values for sample (iv) suggest that a mixture of $\mathrm{Au}$ and $\mathrm{Bi}_{2} \mathrm{O}_{3}$ sintered on $\mathrm{YSZ}$ is a good candidate for SOFC cathodes.

\subsection{Silver (Ag)}

\subsubsection{Introduction}

There are contradictory ideas on the current collection ability of Silver (Ag). Some state that it is a poor current collector due to its high volatility at high temperatures which makes it less inert [4]. However, some people show that lowest resistances were always achieved 
when Ag current collectors were used [11]. Also, Ag is reported to be a good catalyst for oxygen reduction reaction which makes it a suitable candidate for SOFC cathodes [11].

\subsubsection{Sample Preparation}

Different symmetrical cells (3) listed below were prepared using pure Ag paste (Fuel Cell Materials) on bare/ $\mathrm{Bi}_{2} \mathrm{O}_{3}$-modified $\mathrm{YSZ}$ electrolytes.

i. $\quad \mathrm{Ag}($ thin)/bare YSZ: A thin layer of Ag paste was painted on bare YSZ electrolyte surface and sintered at $700{ }^{0} \mathrm{C}$ or $800{ }^{\circ} \mathrm{C}$.

ii. $\quad \operatorname{Ag}(1$ tape thick)/bare YSZ: A thick layer of Ag paste (thickness of the tape used to define the electrode area) was painted on bare YSZ electrolyte surface and sintered at $800{ }^{\circ} \mathrm{C}$.

iii. $\mathrm{Ag} / \mathrm{Bi}_{2} \mathrm{O}_{3}-\mathrm{YSZ}$ : Ag electrodes were painted on $\mathrm{Bi}_{2} \mathrm{O}_{3}$ deposited YSZ substrates and sintered at $800{ }^{\circ} \mathrm{C}$.

\subsubsection{Electrochemical Characterization}

These symmetrical cells were electrochemically characterized by $\mathrm{CV}$ and EIS at $800{ }^{0} \mathrm{C}$, $750{ }^{\circ} \mathrm{C}$ and $700{ }^{\circ} \mathrm{C}$ using $\mathrm{Ag}$ wires and $\mathrm{Ag}$ paste. Some cells were aged at $700{ }^{\circ} \mathrm{C}$ for a certain time period and the electrochemical characterization was repeated at the above mentioned temperatures.

\subsubsection{Results and Discussion}

Note: When the same cell was re-characterized/aged, it is shown with a (') or (") or (" "), and further details are given in the table. Calculated activation energies and only the resistances measured at $800{ }^{0} \mathrm{C}$ are presented in tables so that the resistances at the other temperatures can be calculated.

Unlike Au and Pt containing cells, Ag containing cells showed low series and polarization resistances that were reproducible (Table 2.5). Compared to $\mathrm{Au}$ and $\mathrm{Pt}, \mathrm{Ag}$ was well sintered on bare YSZ electrolytes as confirmed by the $\mathrm{R}_{\mathrm{s}}$ values which are around $0.7-0.8$ $\mathrm{Ohmcm}^{2}$ (Table 2.6). 
When thick Ag electrodes were compared with thin Ag electrodes, both showed the same $R_{s}$ values but different activation energies for conductivity across the cell. Also, the $R_{p}$ values increased when thicker Ag electrodes were used. This may occur due to limited oxygen transport to the $\mathrm{Ag} / \mathrm{YSZ}$ interface in thicker silver layers, which results in increased polarization and total resistances.

Table 2.5: Series resistances, polarization resistances and activation energies of Ag containing cells.

\begin{tabular}{|c|c|c|c|c|c|}
\hline Sample & Description & $\begin{array}{c}R_{\mathrm{s}} \\
\left(\mathrm{Ohmcm}^{2}\right) \\
\text { at } 800^{0} \mathrm{C} \\
\end{array}$ & $\begin{array}{l}E_{a}(e V) \\
\text { for } R_{s}\end{array}$ & $\begin{array}{c}\mathrm{R}_{\mathrm{p}} \\
\left(\mathrm{Ohmcm}^{2}\right) \\
\text { at } 800^{0} \mathrm{C} \\
\end{array}$ & $\begin{array}{l}E_{a}(e V) \\
\text { for } R_{p}\end{array}$ \\
\hline i (a) & $\begin{array}{l}\text { Ag (thin)/bare YSZ sintered at } \\
700{ }^{\circ} \mathrm{C}\end{array}$ & 1.08 & $\begin{array}{c}1.1 \\
(+/-0.0)\end{array}$ & 0.38 & $\begin{array}{c}1.3 \\
(+/-0.2)\end{array}$ \\
\hline $\mathrm{i}(\mathrm{b})$ & $\begin{array}{l}\text { Ag (thin)/bare YSZ sintered at } \\
800{ }^{\circ} \mathrm{C}\end{array}$ & 0.72 & $\begin{array}{c}0.9 \\
(+/-0.0)\end{array}$ & 0.75 & $\begin{array}{c}1.0 \\
(+/-0.0) \\
\end{array}$ \\
\hline $\mathrm{i}(\mathrm{c})$ & $\begin{array}{l}\mathrm{Ag}(\text { thin) } / \text { bare YSZ sintered at } \\
800{ }^{\circ} \mathrm{C}\end{array}$ & 0.65 & $\begin{array}{c}0.9 \\
(+/-0.0) \\
\end{array}$ & 0.64 & $\begin{array}{c}1.0 \\
(+/-0.0) \\
\end{array}$ \\
\hline $\mathrm{i}(\mathrm{c})^{\prime}$ & $\begin{array}{l}\mathrm{Ag}(\text { thin) } / \text { bare YSZ sintered at } \\
800{ }^{\circ} \mathrm{C} \text {, aged } \sim 24 \mathrm{hrs}\end{array}$ & 0.68 & $\begin{array}{c}0.9 \\
(+/-0.0)\end{array}$ & 0.7 & $\begin{array}{c}1.0 \\
(+/-0.0)\end{array}$ \\
\hline ii (a) & $\begin{array}{l}\mathrm{Ag}(1 \text { tape thick }) / \text { bare } \mathrm{YSZ} \\
\text { sintered at } 800^{\circ} \mathrm{C} \text {, heating }\end{array}$ & 0.75 & $\begin{array}{c}0.7 \\
(+/-0.0) \\
\end{array}$ & 4.45 & $\begin{array}{c}1.0 \\
(+/-0.0) \\
\end{array}$ \\
\hline ii (a)' & $\begin{array}{l}\mathrm{Ag}(1 \text { tape thick }) / \text { bare YSZ } \\
\text { sintered at } 800^{\circ} \mathrm{C} \text {, cooling }\end{array}$ & 0.76 & $\begin{array}{c}0.7 \\
(+/-0.0) \\
\end{array}$ & 4.59 & $\begin{array}{c}1.1 \\
(+/-0.1) \\
\end{array}$ \\
\hline ii (a)"' & $\begin{array}{l}\text { Ag (1 tape thick)/bare YSZ } \\
\text { sintered at } 800{ }^{0} \mathrm{C} \text {, aged } \sim 48 \\
\text { hrs, heating }\end{array}$ & 0.75 & $\begin{array}{c}0.7 \\
(+/-0.0)\end{array}$ & 4.40 & $\begin{array}{c}1.0 \\
(+/-0.1)\end{array}$ \\
\hline ii (a)", & $\begin{array}{l}\mathrm{Ag}(1 \text { tape thick)/bare YSZ } \\
\text { sintered at } 800{ }^{0} \mathrm{C} \text {, aged } \sim 48 \\
\text { hrs, cooling }\end{array}$ & 0.75 & $\begin{array}{c}0.7 \\
(+/-0.0)\end{array}$ & 4.52 & $\begin{array}{c}1.1 \\
(+/-0.1)\end{array}$ \\
\hline ii (b) & $\begin{array}{l}\text { Ag (1 tape thick)/bare YSZ } \\
\text { sintered at } 800{ }^{\circ} \mathrm{C} \text {, heating }\end{array}$ & 0.77 & $\begin{array}{c}0.7 \\
(+/-0.0) \\
\end{array}$ & 3.97 & $\begin{array}{c}0.9 \\
(+/-0.1) \\
\end{array}$ \\
\hline ii (b)' & $\begin{array}{l}\mathrm{Ag}(1 \text { tape thick }) / \text { bare YSZ } \\
\text { sintered at } 800^{\circ} \mathrm{C} \text {, cooling }\end{array}$ & 0.78 & $\begin{array}{c}0.7 \\
(+/-0.0) \\
\end{array}$ & 4.01 & $\begin{array}{c}1.2 \\
(+/-0.1) \\
\end{array}$ \\
\hline ii (c) & $\begin{array}{l}\text { Ag (1 tape thick)/bare YSZ } \\
\text { sintered at } 800^{\circ} \mathrm{C} \text {, heating }\end{array}$ & 0.77 & $\begin{array}{c}0.7 \\
(+/-0.0)\end{array}$ & 3.44 & $\begin{array}{c}1.0 \\
(+/-0.1) \\
\end{array}$ \\
\hline ii (c)' & $\begin{array}{l}\mathrm{Ag}(1 \text { tape thick }) / \text { bare YSZ } \\
\text { sintered at } 800{ }^{\circ} \mathrm{C} \text {, cooling }\end{array}$ & 0.77 & $\begin{array}{c}0.7 \\
(+/-0.0) \\
\end{array}$ & 3.54 & $\begin{array}{c}1.2 \\
(+/-0.1) \\
\end{array}$ \\
\hline iii & $\begin{array}{l}\mathrm{Ag} / \mathrm{Bi}_{2} \mathrm{O}_{3}-\mathrm{YSZ}, \mathrm{Bi}\left(\mathrm{NO}_{3}\right)_{3} \\
\text { sintered at } 850{ }^{\circ} \mathrm{C}, \mathrm{Ag} \text { sintered } \\
\text { at } 800{ }^{\circ} \mathrm{C}\end{array}$ & 0.88 & $\begin{array}{c}1.1 \\
(+/-0.0)\end{array}$ & 0.77 & $\begin{array}{c}1.2 \\
(+/-0.0)\end{array}$ \\
\hline
\end{tabular}


Table 2.6: Summary of average series resistances and activation energies for conductivity across the cell of Ag containing cells.

\begin{tabular}{|c|c|c|c|c|}
\hline Sample & $\begin{array}{c}\text { Average } \mathbf{R}_{\mathbf{s}} \text { at } \\
\mathbf{8 0 0} \mathbf{~}^{\mathbf{C}} \\
\left(\mathbf{O h m c m}^{\mathbf{2}}\right)\end{array}$ & $\begin{array}{c}\text { Standard } \\
\text { deviation }\end{array}$ & $\begin{array}{c}\text { Average } \mathbf{E}_{\mathbf{a}} \text { for } \\
\mathbf{R}_{\mathbf{s}} \mathbf{( e V )}\end{array}$ & $\begin{array}{c}\text { Standard } \\
\text { deviation }\end{array}$ \\
\hline (i) & 0.8 & $+/-0.2$ & 0.9 & $+/-0.1$ \\
\hline (ii) & 0.8 & $+/-0.0$ & 0.7 & $+/-0.0$ \\
\hline (iii) & 0.9 & - & 1.1 & $+/-0.0$ \\
\hline
\end{tabular}

Due to high oxygen solubility in silver [1], it acts as a better SOFC cathode compared to Pt and $\mathrm{Au}$ which show very low oxygen solubility. Sarikaya et al. [1] have reported 1.85 $\mathrm{Ohmcm}^{2}$ as the $\mathrm{R}_{\mathrm{p}}$ value at $800{ }^{0} \mathrm{C}$ for their $\mathrm{Ag} / \mathrm{YSZ}$ symmetric cells. However we have observed very low $R_{p}$ values $\left(\sim 0.7 \mathrm{Ohmcm}^{2}\right)$ for thin $\mathrm{Ag}$ electrodes and much higher $\mathrm{R}_{\mathrm{p}}$ values $\left(\sim 4.0 \mathrm{Ohmcm}^{2}\right)$ for thick $\mathrm{Ag}$ electrodes, at $800{ }^{\circ} \mathrm{C}$.

Similar to the $\mathrm{Pt}$ and $\mathrm{Au}$ systems, very low $\mathrm{R}_{\mathrm{s}}$ and $\mathrm{R}_{\mathrm{p}}$ values were obtained when $\mathrm{Ag}$ electrodes were painted on $\mathrm{Bi}_{2} \mathrm{O}_{3}$ modified $\mathrm{YSZ}$, which is attributed to the high ionic conductivity of $\mathrm{Bi}_{2} \mathrm{O}_{3}$ and its ability to act as a sintering aid.

Short term aging study of Ag/YSZ symmetric cells (Samples 1(d), ii(c) and ii(d)) show that Ag electrodes did not significantly deteriorate with time when aged at $700{ }^{0} \mathrm{C}$. However, when operated at $800{ }^{0} \mathrm{C}$ for a long time, Ag particles tend to agglomerate and sinter together which reduces its porosity, resulting in deterioration of its collection properties [1] and its ability to act as a cathode in SOFCs.

\subsubsection{Summary}

$\mathrm{Ag}$ showed good adhesion to YSZ electrolytes even in the absence of a sintering aid. Therefore, we have decided to continue using Ag paste as one of the current collectors in our future studies. Also, Ag current collectors were extensively studied using the Solartron system and the results will be discussed in Chapter 04 . 


\subsection{Lanthanum Strontium Manganite (LSM)}

\subsubsection{Introduction}

Lanthanum Strontium Manganite (LSM) is the most investigated, widely used cathode material in high temperature SOFCs [13]. Also, LSM is used as a current collector in SOFC cathodes [14]. We have characterized only one LSM/YSZ symmetric cell using the PAR system as a preliminary study.

\subsubsection{Sample Preparation}

Commercial LSM powder (( $\left.\left.\mathrm{La}_{0.8} \mathrm{Sr}_{0.2}\right) \mathrm{MnO}_{3-\delta}\right)$ bought from Fuel Cell Materials was mixed with $\alpha$ - terpineol (2:1 by weight) to make a thick LSM paste which was painted on both sides of a YSZ electrolyte and sintered at $1200^{\circ} \mathrm{C}$.

\subsubsection{Electrochemical Characterization}

This LSM/YSZ symmetrical cell was electrochemically characterized by CV and EIS at

$800{ }^{\circ} \mathrm{C}, 750{ }^{\circ} \mathrm{C}$ and $700{ }^{\circ} \mathrm{C}$ using Ag wires. No metal current collectors were used and a small amount of Ag paste was used to attach the Ag wires on to the LSM electrode. Then, this cell was aged for $\sim 24$ hours at $700{ }^{0} \mathrm{C}$ and the electrochemical characterization was repeated at the above mentioned temperatures.

\subsubsection{Results and Discussion}

Note: When the same cell was re-characterized/aged, it is shown with a (") or (") or (")"), and further details are given in the table. Calculated activation energies and only the resistances measured at $800{ }^{0} \mathrm{C}$ are presented in tables so that the resistances at the other temperatures can be calculated.

Only one LSM/YSZ symmetric cell was characterized using PAR system (Table 2.7). $\mathrm{R}_{\mathrm{s}}$ $\sim 0.8 \mathrm{Ohmcm}^{2}$ suggests that the LSM electrodes were properly sintered on YSZ electrolyte. Also, $\mathrm{R}_{\mathrm{p}}$ drastically increased when the cell was aged at $700{ }^{0} \mathrm{C}$ for $\sim 24 \mathrm{hrs}$. 
Table 2.7: Series resistances, polarization resistances and activation energies of LSM/YSZ symmetric cells.

\begin{tabular}{|c|c|c|c|c|c|}
\hline Sample & Description & $\begin{array}{c}\mathrm{R}_{\mathrm{s}} \\
\left(\mathrm{Ohmcm}^{2}\right) \\
\text { at } 800^{0} \mathrm{C} \\
\end{array}$ & $\begin{array}{c}E_{a}(e V) \\
\text { for } R_{s}\end{array}$ & $\begin{array}{c}\mathbf{R}_{\mathrm{p}} \\
\left(\mathrm{Ohmcm}^{2}\right) \\
\text { at } 800^{\circ} \mathrm{C} \\
\end{array}$ & $\begin{array}{c}E_{a}(e V) \\
\text { for } R_{p}\end{array}$ \\
\hline i (a) & $\begin{array}{l}\mathrm{LSM} / \mathrm{YSZ} \text { sintered at } \\
1200^{\circ} \mathrm{C} \text {, heating }\end{array}$ & 0.8 & $\begin{array}{c}0.6 \\
(+/-0.0) \\
\end{array}$ & 10.1 & $\begin{array}{c}0.7 \\
(+/-0.0) \\
\end{array}$ \\
\hline i (a)' & $\begin{array}{l}\mathrm{LSM} / \mathrm{YSZ} \text { sintered at } \\
1200^{\circ} \mathrm{C} \text {, cooling }\end{array}$ & 0.8 & $\begin{array}{c}0.7 \\
(+/-0.1) \\
\end{array}$ & 10.4 & $\begin{array}{c}1.1 \\
(+/-0.1)\end{array}$ \\
\hline i (a)", & $\begin{array}{l}\text { LSM/ YSZ sintered at } \\
1200{ }^{0} \mathrm{C}, \text { aged } \sim 24 \mathrm{hrs}, \\
\text { heating }\end{array}$ & 0.8 & $\begin{array}{c}0.7 \\
(+/-0.0)\end{array}$ & 23.9 & $\begin{array}{c}1.0 \\
(+/-0.0)\end{array}$ \\
\hline
\end{tabular}

We have extensively studied LSM/YSZ symmetrical cells using the Solartron system and the results of those studies will be discussed in detail in Chapter 04.

\subsubsection{Summary}

The symmetrical cell (LSM/YSZ) that was characterized using the PAR system looked promising since it showed good adhesion and low $R_{s}$ values. However, its major disadvantage is the requirement of a high sintering temperature compared to the metal current collectors. LSM was further studied as a current collector using the Solartron system.

\subsection{Conclusion}

$\mathrm{Pt}, \mathrm{Au}, \mathrm{Ag}$ and LSM are already in use as current collectors for SOFCs. The purpose of this study was to choose the most suitable current collector for the electrochemical characterization of our symmetrical cells. Since it was difficult to overcome the delamination of Pt and Au electrodes from YSZ; we have decided to continue using Ag and LSM as the current collectors for YSZ based electrodes since they exhibit good adhesion properties and reproducible performance. Detailed analysis of LSM and Ag current collectors (using the Solartron system) will be presented in Chapter 03 and Chapter 04. Adding an oxide ion conductor (eg: $\mathrm{Bi}_{2} \mathrm{O}_{3}, \mathrm{YSZ}$ ) to a noble metal that is a pure electronic conductor (eg: $\mathrm{Pt}, \mathrm{Au}$ ) lowered the $\mathrm{R}_{\mathrm{p}}$ and $\mathrm{R}_{\mathrm{s}}$ values of the cathodes in some cases. 
However, most of them did not show good adhesion to the YSZ electrolyte which can be further proven by high $R_{s}$ values. 


\section{Section II}

\section{YSZ nanofiber cathodes (PAR system)}

\subsection{Introduction}

As discussed in Chapter 1, performance of SOFC highly depends on its cathode. Optimizing the microstructure to increase the porosity and to extend the Triple Phase Boundary (TPB) length [15] or the surface area is one approach to reduce the polarization losses at the cathode.

Oxygen reduction in a porous SOFC cathode is known to be a surface reaction. Therefore, it is important to have increased gas/solid interfacial area. 1-D nanofibers have high surface/volume ratio which increases the number of active reaction sites and the catalytic activity [3], [16]. Also, having a continuous charge transfer pathway within the microstructure increases the charge mobility and decreases the overpotential [16] ("overpotential is the additional potential beyond the thermodynamic requirement) that is needed to drive a reaction at a certain rate" [17]). Furthermore, the nanofiber cathode structure is more porous than the conventional powder cathode (Figure 2.6) which facilitates the gas transport through the cathode.
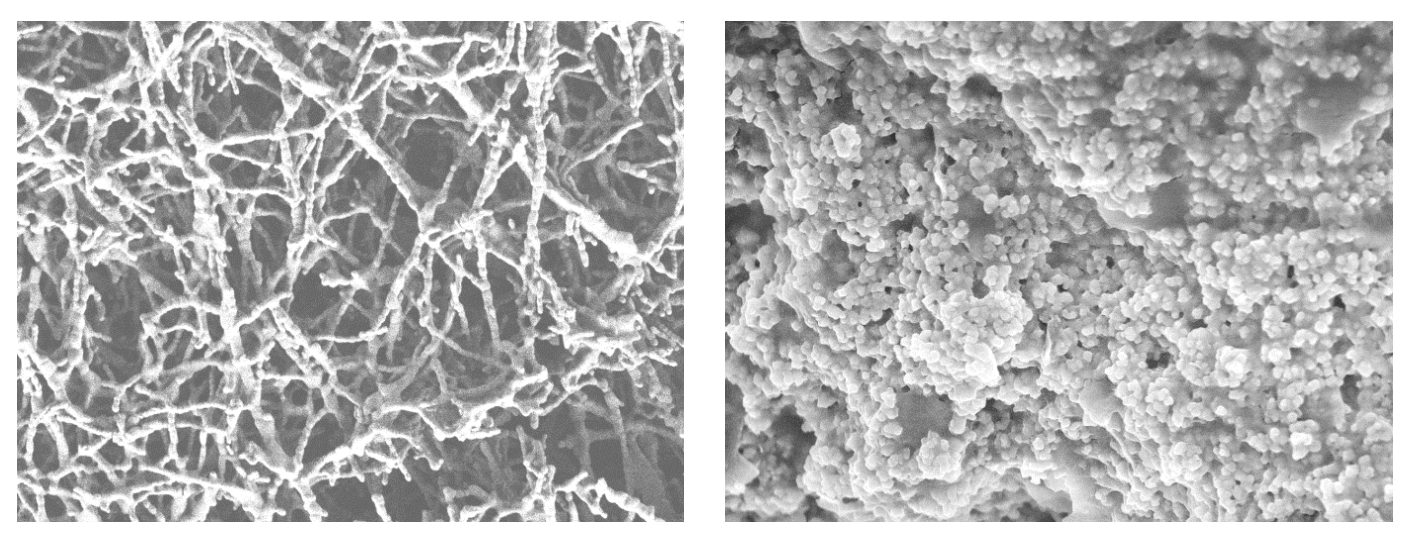

Figure 2.6: SEM images of a (a) YSZ nanofiber cathode sintered at $1300{ }^{\circ} \mathrm{C}(3000 \mathrm{X})$ and (b) YSZ powder cathode sintered at $1500{ }^{\circ} \mathrm{C}(5000 \mathrm{X})$ on YSZ electrolyte. 
As we have discussed before, a higher density of TPBs increases the SOFC cathode performance. The conventional method of achieving this is mixing ionic conductor (YSZ) and electronic conductor (LSM) powders together and sintering at a higher temperature to create a composite cathode. The major difficulty is finding an optimum sintering temperature for both powders while avoiding degradation reactions. However, the infiltration technique appears to produce SOFC cathodes that have better performance while avoiding the issue of an optimum sintering temperature for two materials. In this technique, the porous cathode backbone (YSZ) is sintered at a higher temperature to ensure proper connectivity between the electrolyte and the cathode. Then, the porous scaffold is infiltrated with a solution to form the second phase (LSM) and sintered at a relatively low temperature. This approach minimizes unfavorable side reactions between the two phases and also delaminating issues due to mismatch of Thermal Expansion Coefficients (TECs) [18].

In this study, we will compare the preliminary results of the performance of non-infiltrated YSZ cathodes with the infiltrated YSZ cathodes and also the difference between powderbased and nanofiber-based YSZ cathodes. Infiltration methods used and the results obtained using the Solartron system will be discussed in detail in Chapter 03.

\subsection{Experimental}

We received YSZ nanofiber samples from Dr. Nick Wu and Dr. Mingjia Zhi (Department of Mechanical and Aerospace Engineering, WVU). They have used the "electrospinning" technique to synthesize YSZ nanofibers [19].

Electrospinning technique is less expensive and simpler than the template-derived method. As shown in Figure 2.7, an electrospinning apparatus usually consists of a high voltage supply, a syringe with a metallic needle and a ground collector. In a typical spinning process, the syringe is filled with the viscous precursors and a high voltage is applied between the needle and the ground collector. At a critical voltage, the repulsion between the charged polymer molecules of the precursor solution overcomes the surface tension and the liquid droplet at the needle tip stretches as a liquid jet towards the low potential [20]. When it reaches the ground collector, the liquid jet dries into solid 
nanofibers [16]. Subsequent firing converts the dried blend of polymer and metal salts to the desired oxide material without loss of the nanofiber morphology (Figure 2.8).

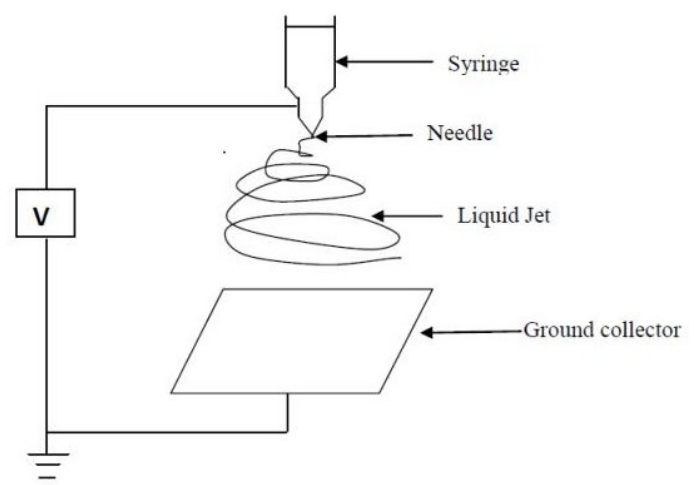

Figure 2.7: The Electrospinning apparatus.

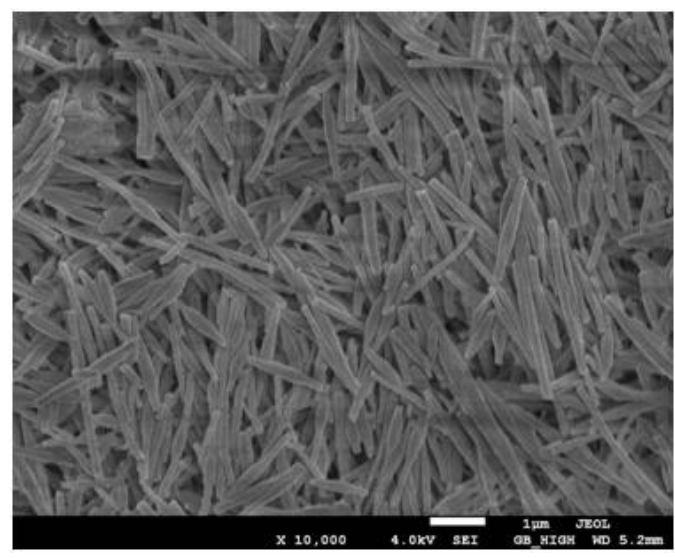

Figure 2.8: YSZ nanofibers sintered at $400{ }^{\circ} \mathrm{C}$ on an $\mathrm{YSZ}$ electrolyte.

Our goal was to create a porous YSZ nanofiber cathode that sinters well to the YSZ electrolyte, while retaining the structure of the nanofibers. However, delamination of nanofibers from the YSZ electrolyte was observed after sintering at lower temperatures. In order to overcome delamination, we tried using roughened YSZ surfaces (by HF etching) and also a well known sintering aid $\mathrm{Bi}_{2} \mathrm{O}_{3}$. Using $\mathrm{Bi}_{2} \mathrm{O}_{3}$ to sinter $\mathrm{YSZ}$ at lower temperatures has been extensively studied and it is reported that the sintered YSZ has a dense structure with smaller grains when $\mathrm{Bi}_{2} \mathrm{O}_{3}$ is present [21]. Furthermore, a study was carried out to find the suitable sintering temperature for YSZ nanofibers. 


\subsubsection{Sintering Study}

YSZ nanofibers were mixed with $\alpha$-terpineol (1:10 by weight YSZ nanofiber : $\alpha$-terpineol) to make a paste which was painted on YSZ electrolyte substrates. Then, these samples were sintered at $850{ }^{\circ} \mathrm{C}, 1100{ }^{0} \mathrm{C}, 1150{ }^{\circ} \mathrm{C}, 1200{ }^{\circ} \mathrm{C}, 1250{ }^{\circ} \mathrm{C}, 1300{ }^{\circ} \mathrm{C}, 1350{ }^{\circ} \mathrm{C}, 1400{ }^{0} \mathrm{C}$ and $1450{ }^{\circ} \mathrm{C}$ for 1 hour. Then, they were observed under a Scanning Electron Microscope (SEM) to study the porous YSZ structure (Figure 2.9).

\subsubsection{Electrochemical Characterization}

Different symmetrical cells and half cells were prepared using YSZ nanofiber paste (1:10 by weight YSZ nanofiber : $\alpha$-terpineol) and/or YSZ powder paste (1:1:2 by weight YSZ powder: graphite powder : $\alpha$-terpineol) on bare/roughened/ $\mathrm{Bi}_{2} \mathrm{O}_{3}$-modified YSZ electrolytes. A double sided tape was used to define the area and the thickness of the electrode before sintering. Sometimes, two tapes were used on top of each other in order to prepare thicker electrodes. After drying the electrode at $\sim 150{ }^{\circ} \mathrm{C}$, the tapes were carefully removed before the cells were sintered at higher temperatures. $\mathrm{Pt}, \mathrm{Au}$ or $\mathrm{Ag}$ current collectors were used and the cells were electrochemically characterized by CV and EIS at $800{ }^{\circ} \mathrm{C}, 750{ }^{\circ} \mathrm{C}$ and $700{ }^{\circ} \mathrm{C}$ (while heating from $700{ }^{\circ} \mathrm{C}$ to $800{ }^{\circ} \mathrm{C}$ and/or cooling from 800 ${ }^{0} \mathrm{C}$ to $700{ }^{\circ} \mathrm{C}$ ) using $\mathrm{Au}$ or $\mathrm{Ag}$ wires. Some cells were aged at $700{ }^{0} \mathrm{C}$ for a certain time period and the electrochemical characterization was repeated at the above mentioned temperatures. A set of initial measurements were made on LSM infiltrated YSZ scaffolds as well. However, since this work was continued using the Solartron system, the results of infiltrated cathodes will be discussed in detail in Chapter 3.

\subsection{Results and Discussion}

\subsubsection{Sintering Study}

The "sintering study" (Figure 2.9) showed that at temperatures lower than $1300{ }^{\circ} \mathrm{C}$, YSZ nanofibers did not sinter well. At temperatures above $1350{ }^{\circ} \mathrm{C}$, the nanofiber structures were melted. However at $1300{ }^{\circ} \mathrm{C}$ and $1350{ }^{\circ} \mathrm{C}$, nanofibers sintered well while retaining their structure. 

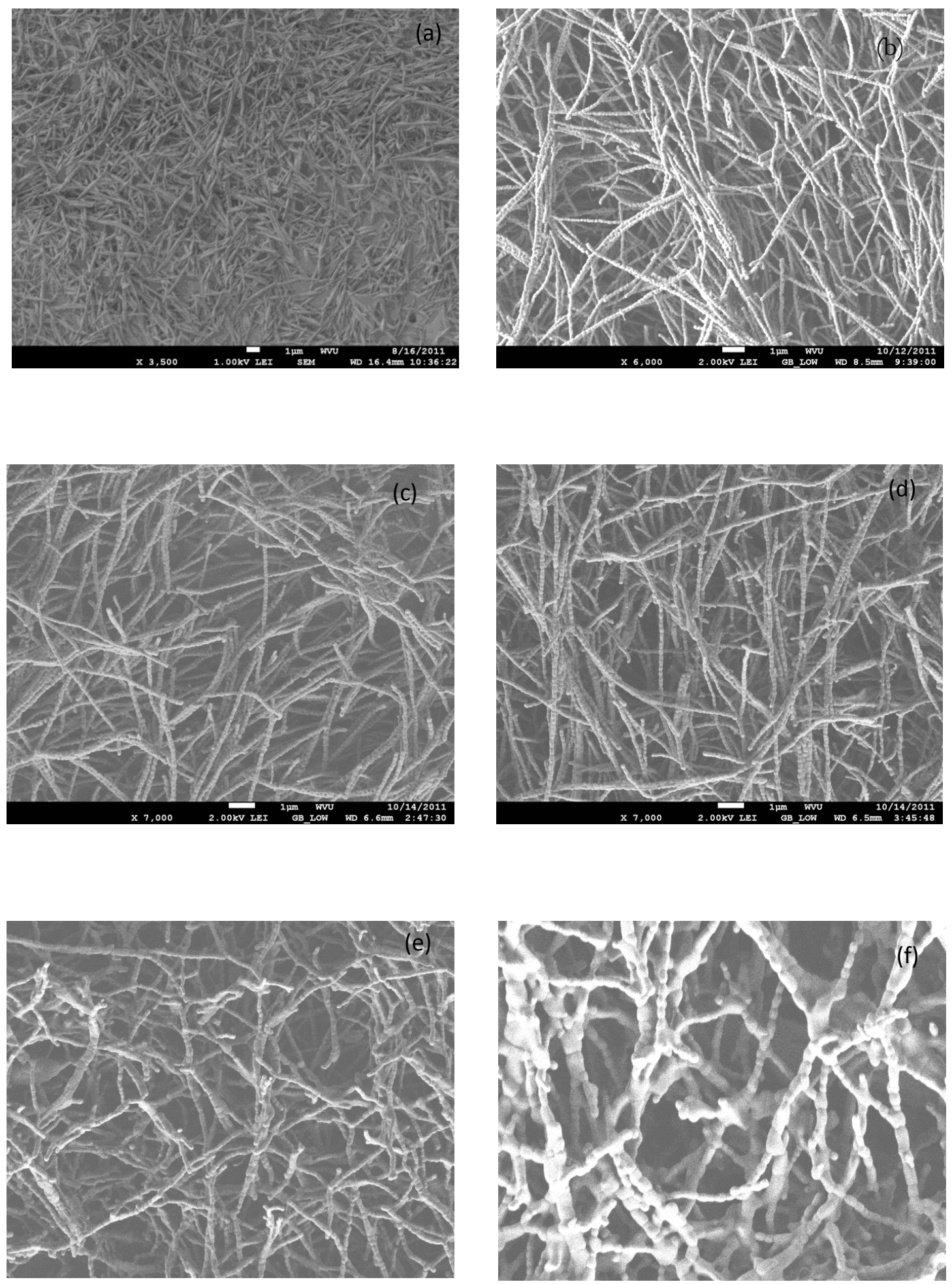

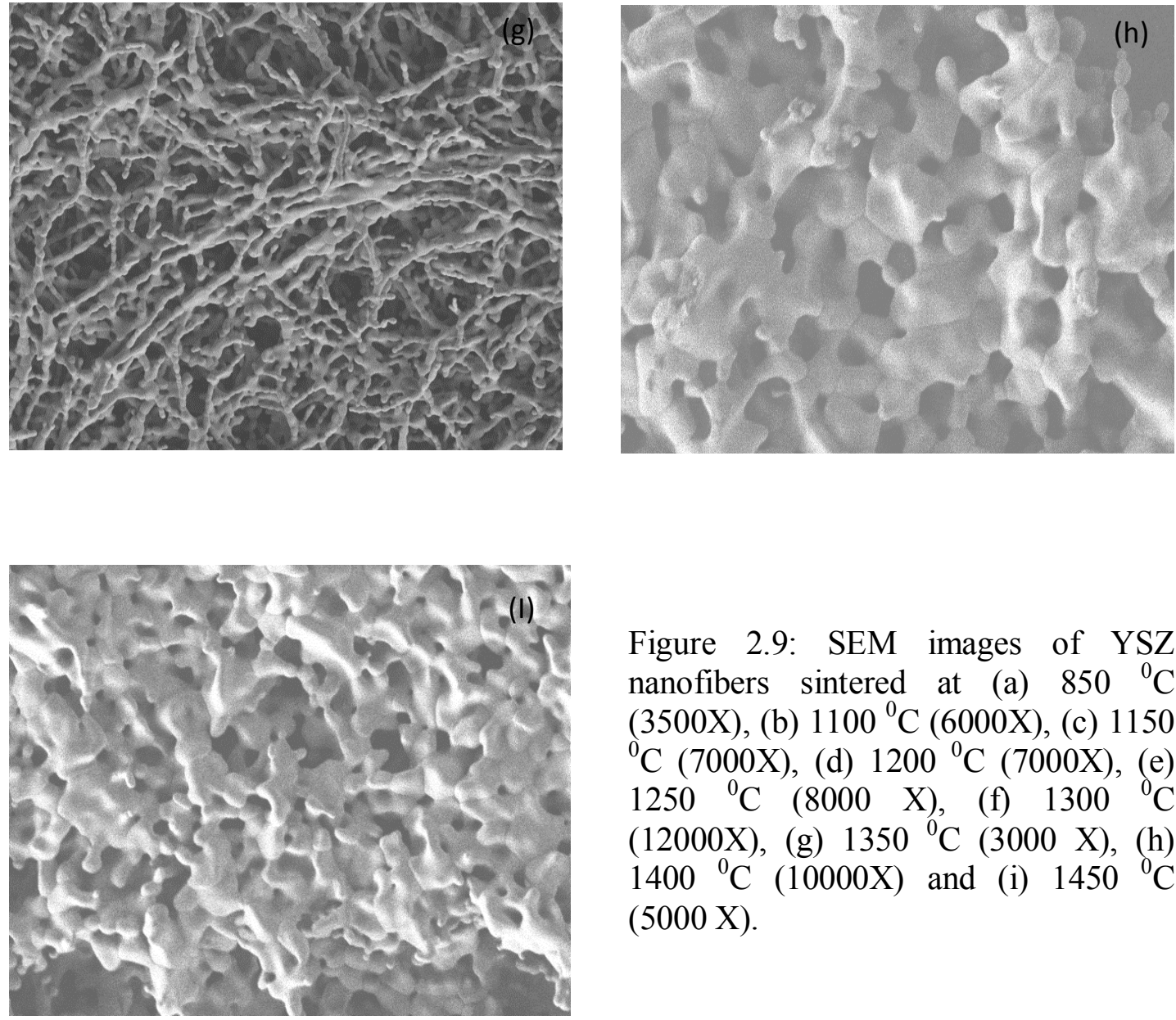

Figure 2.9: SEM images of YSZ nanofibers sintered at (a) $850{ }^{0} \mathrm{C}$ (3500X), (b) $1100{ }^{\circ} \mathrm{C}(6000 \mathrm{X}),(\mathrm{c}) 1150$ ${ }^{0} \mathrm{C}(7000 \mathrm{X}),(\mathrm{d}) 1200{ }^{0} \mathrm{C}(7000 \mathrm{X}),(\mathrm{e})$ $1250{ }^{0} \mathrm{C} \quad(8000 \quad \mathrm{X}), \quad(\mathrm{f}) \quad 1300{ }^{0} \mathrm{C}$ $(12000 \mathrm{X}),(\mathrm{g}) 1350{ }^{0} \mathrm{C}(3000 \mathrm{X}),(\mathrm{h})$ $1400{ }^{0} \mathrm{C}(10000 \mathrm{X})$ and (i) $1450{ }^{\circ} \mathrm{C}$ $(5000 \mathrm{X})$.

\subsubsection{Pt current collectors on YSZ nanofiber cathodes}

Cells characterized:

i. Pt/YSZ nanofiber/YSZ: YSZ nanofiber electrodes were painted on bare YSZ electrolyte surface and sintered at $1100{ }^{0} \mathrm{C}$. Then, Pt paint was applied on top of the YSZ nanofiber electrodes and sintered again at $1100{ }^{\circ} \mathrm{C}$.

ii. $\mathrm{Pt} / \mathrm{YSZ}$ nanofiber/ $\mathrm{Bi}_{2} \mathrm{O}_{3}-\mathrm{YSZ}$ : YSZ nanofiber electrodes were painted on $\mathrm{Bi}_{2} \mathrm{O}_{3}$ deposited YSZ substrates and sintered at $1100{ }^{0} \mathrm{C}$ or $850{ }^{\circ} \mathrm{C}$. Then, Pt paint was applied on top of the YSZ nanofiber electrodes and sintered again at $1100{ }^{\circ} \mathrm{C}$ or $850{ }^{0} \mathrm{C}$. 
Note: When the same cell was re-characterized/aged, it is shown with a (') and further details are given in the table. Calculated activation energies and only the resistances measured at $800{ }^{0} \mathrm{C}$ are presented in tables so that the resistances at the other temperatures can be calculated.

Table 2.8: Series resistances, polarization resistances and activation energies of YSZ nanofiber cathodes with Pt current collectors.

\begin{tabular}{|c|c|c|c|c|c|}
\hline Sample & Description & $\begin{array}{c}\mathbf{R}_{\mathrm{s}} \\
\left(\mathrm{Ohmcm}^{2}\right) \\
\text { at } 800^{0} \mathrm{C}\end{array}$ & $\begin{array}{c}E_{a}(e V) \\
\text { for } R_{s}\end{array}$ & $\begin{array}{c}\mathbf{R}_{\mathrm{p}} \\
\left(\mathrm{Ohmcm}^{2}\right) \\
\text { at } 800^{0} \mathrm{C}\end{array}$ & $\begin{array}{c}E_{a}(e V) \\
\text { for } R_{p}\end{array}$ \\
\hline i (a) & $\begin{array}{l}\text { Pt/YSZ nanofiber/YSZ, nanofiber } \\
\text { sintered at } 1100{ }^{0} \mathrm{C}, \mathrm{Pt} \text { sintered at } \\
1100{ }^{0} \mathrm{C}\end{array}$ & 5.67 & $\begin{array}{c}1.5 \\
(+/-0.1)\end{array}$ & 22.42 & $\begin{array}{c}2.0 \\
(+/-0.1)\end{array}$ \\
\hline i (a)' & $\begin{array}{l}\mathrm{Pt} / \mathrm{YSZ} \text { nanofiber/YSZ, nanofiber } \\
\text { sintered at } 1100{ }^{0} \mathrm{C}, \mathrm{Pt} \text { sintered at } \\
1100{ }^{0} \mathrm{C}(\sim 48 \mathrm{hrs} \text { aged })\end{array}$ & 4.07 & $\begin{array}{c}1.6(+/- \\
0.1)\end{array}$ & 17.67 & $\begin{array}{c}1.5 \\
(+/-0.1)\end{array}$ \\
\hline ii (a) & $\begin{array}{l}\mathrm{Pt} / \mathrm{YSZ} \text { nanofiber/ } \mathrm{Bi}_{2} \mathrm{O}_{3}-\mathrm{YSZ}, \\
\mathrm{Bi}\left(\mathrm{NO}_{3}\right)_{3} \text { sintered at } 850{ }^{0} \mathrm{C} \text {, } \\
\text { nanofiber sintered at } 850{ }^{0} \mathrm{C}, \mathrm{Pt} \\
\text { sintered at } 850{ }^{0} \mathrm{C}\end{array}$ & 1.15 & $\begin{array}{c}1.1 \\
(+/ 0.0)\end{array}$ & 0.51 & $\begin{array}{c}2.7 \\
(+/-0.2)\end{array}$ \\
\hline ii (b) & $\begin{array}{l}\mathrm{Pt} / \mathrm{YSZ} \text { nanofiber } / \mathrm{Bi}_{2} \mathrm{O}_{3}-\mathrm{YSZ}, \\
\mathrm{Bi}\left(\mathrm{NO}_{3}\right)_{3} \text { sintered at } 850{ }^{0} \mathrm{C} \text {, } \\
\text { nanofiber sintered at } 850{ }^{0} \mathrm{C}, \mathrm{Pt} \\
\text { sintered at } 850{ }^{0} \mathrm{C}\end{array}$ & 0.80 & $\begin{array}{c}0.9 \\
(+/ 0.0)\end{array}$ & 0.32 & $\begin{array}{c}2.4 \\
(+/-0.2)\end{array}$ \\
\hline ii(c) & $\begin{array}{l}\mathrm{Pt} / \mathrm{YSZ} \text { nanofiber/ } \mathrm{Bi}_{2} \mathrm{O}_{3}-\mathrm{YSZ}, \\
\mathrm{Bi}\left(\mathrm{NO}_{3}\right)_{3} \text { sintered at } 850{ }^{0} \mathrm{C} \text {, } \\
\text { nanofiber sintered at } 1100{ }^{0} \mathrm{C}, \mathrm{Pt} \\
\text { sintered at } 1100{ }^{0} \mathrm{C}\end{array}$ & 0.87 & $\begin{array}{c}1.0 \\
(+/ 0.0)\end{array}$ & 6.21 & $\begin{array}{c}2.8 \\
(+/-0.1)\end{array}$ \\
\hline
\end{tabular}

When Student's t-test was used for statistical analysis [5], there is a significant difference in average $R_{s}$ and $E_{a}$ values of samples (i) and (ii). However, the comparison of sample (ii) and sample (iv) of Section $2.3\left(\mathrm{Pt} / \mathrm{Bi}_{2} \mathrm{O}_{3}-\mathrm{YSZ}\right)$ shows that there is no significant difference between their average $R_{s}$ or $E_{a}$ values. The significant difference between samples (i) and (ii), and the similarity between samples (ii) and (iv) of Section 2.3 can be attributed to the following observations. The only difference between samples (i) and (ii) was that the YSZ substrate of sample (ii) was modified with $\mathrm{Bi}_{2} \mathrm{O}_{3}$. The SEM images (Figure 2.10) of this sample showed that $\mathrm{Bi}_{2} \mathrm{O}_{3}$ caused the YSZ nanofibers to "melt down" which resulted in a " $\mathrm{Bi}_{2} \mathrm{O}_{3}$ modified roughened YSZ surface". Therefore, this sample (ii) behaved more similar to sample (iv) of Section 2.3, than sample (i). According to Keizr et al. [22], $\mathrm{Bi}_{2} \mathrm{O}_{3}$ promotes low temperature sintering of YSZ by reacting with the fluorite 
phase of $\mathrm{ZrO}_{2}$. This reaction yields a reactive (which might be a liquid) medium that aid the sintering reaction. This might be the reason for our observation of "melted" YSZ nanofibers in the presence of $\mathrm{Bi}_{2} \mathrm{O}_{3}$.

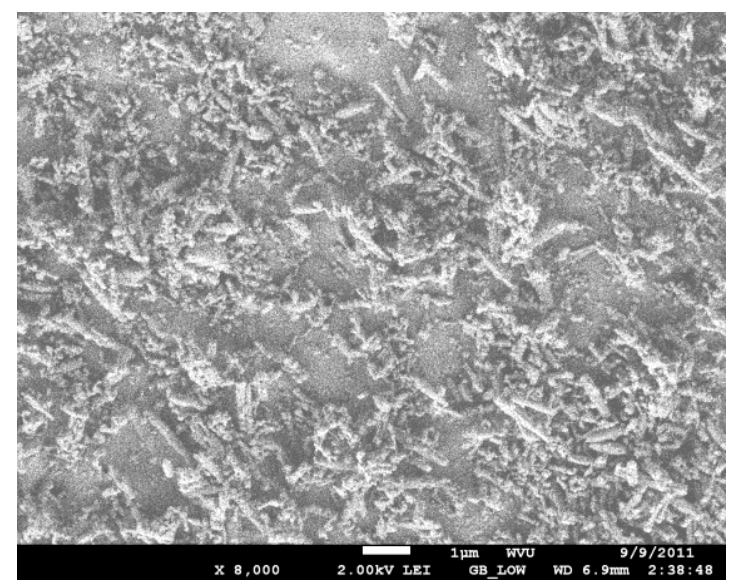

Figure 2.10: YSZ nanofibers sintered with Bi $\left(\mathrm{NO}_{3}\right)_{3}$ at $850{ }^{0} \mathrm{C}$, nanofibers are melted.

$\mathrm{R}_{\mathrm{p}}$ values drastically decreased when $\mathrm{Bi}_{2} \mathrm{O}_{3}$ was incorporated in to symmetric cells. However, sample ii (c) showed a comparatively high $R_{p}$ value may be because Pt was sintered at a higher temperature $\left(1100{ }^{0} \mathrm{C}\right)$.

Furthermore, SEM images of sample (i) clearly showed poor sintering of YSZ nanofibers at $1100{ }^{0} \mathrm{C}$ (Figure 2.9 (b)). This results in a poorly defined pathway for oxide ion conduction from the electrolyte to current collector which results in comparatively higher $\mathrm{R}_{\mathrm{p}}, \mathrm{R}_{\mathrm{s}}$ and $\mathrm{E}_{\mathrm{a}}$ values.

\subsubsection{Au current collectors on YSZ nanofiber cathodes}

Cells characterized:

i. $\mathrm{Au} / \mathrm{Bi}_{2} \mathrm{O}_{3}-\mathrm{YSZ}$ nanofiber/YSZ: YSZ nanofiber and $\mathrm{Bi}_{2} \mathrm{O}_{3}$ powder was mixed together to form a paste which was painted on bare YSZ and sintered at $850{ }^{0} \mathrm{C}$. Then, Au paste was applied on top of those electrodes and sintered at $850{ }^{\circ} \mathrm{C}$.

ii. $\mathrm{Au} / \mathrm{YSZ}$ nanofiber/ $\mathrm{Bi}_{2} \mathrm{O}_{3}$-YSZ: YSZ nanofiber electrodes were painted on $\mathrm{Bi}_{2} \mathrm{O}_{3}$ deposited YSZ substrates and sintered at $850{ }^{\circ} \mathrm{C}$ or $1100{ }^{\circ} \mathrm{C}$. Then, Au paint was applied on top of the YSZ nanofiber electrodes and sintered again at $700{ }^{0} \mathrm{C}$ or $850{ }^{0} \mathrm{C}$. 
Table 2.9: Series resistances, polarization resistances and activation energies of YSZ nanofiber cathodes with Au current collectors.

\begin{tabular}{|c|c|c|c|c|c|}
\hline Sample & Description & $\begin{array}{r}\mathbf{R}_{\mathrm{s}} \\
(\mathrm{Ohmcm} 2) \\
\text { at } 800^{\circ} \mathrm{C}\end{array}$ & $\begin{array}{c}E_{a}(e V) \\
\text { for } R_{s}\end{array}$ & $\begin{array}{c}R_{p} \\
(\mathrm{Ohmcm2}) \\
\text { at } 800^{0} \mathrm{C}\end{array}$ & $\begin{array}{l}E_{a}(e V) \\
\text { for } R_{p}\end{array}$ \\
\hline iii & $\begin{array}{l}\mathrm{Au} / \quad \mathrm{Bi}_{2} \mathrm{O}_{3}-\mathrm{YSZ} \text { nanofiber/YSZ, } \\
\text { mixture sintered at } 850{ }^{0} \mathrm{C}, \quad \mathrm{Au} \\
\text { sintered at } 8500^{\circ} \mathrm{C}\end{array}$ & 0.85 & $\begin{array}{c}0.9 \\
(+/-0.0)\end{array}$ & 1.0 & $\begin{array}{c}1.6 \\
(+/-0.1)\end{array}$ \\
\hline iv (a) & $\begin{array}{l}\mathrm{Au} / \mathrm{YSZ} \text { nanofiber/ } \mathrm{Bi}_{2} \mathrm{O}_{3}-\mathrm{YSZ}, \mathrm{Bi} \\
\left(\mathrm{NO}_{3}\right)_{3} \text { sintered at } 850{ }^{0} \mathrm{C} \text {, YSZ } \\
\text { nanofibers sintered at } 850{ }^{\circ} \mathrm{C}, \mathrm{Au} \\
\text { sintered at } 700{ }^{\circ} \mathrm{C}\end{array}$ & 2.81 & $\begin{array}{c}0.7 \\
(+/-0.1)\end{array}$ & 3.4 & $\begin{array}{c}1.8 \\
(+/-0.0)\end{array}$ \\
\hline iv (b) & $\begin{array}{l}\mathrm{Au} / \mathrm{YSZ} \text { nanofiber/ } \mathrm{Bi}_{2} \mathrm{O}_{3}-\mathrm{YSZ}, \mathrm{Bi} \\
\left(\mathrm{NO}_{3}\right)_{3}, \mathrm{YSZ} \text { nanofibers, Au sintered } \\
\text { at } 850{ }^{\circ} \mathrm{C}\end{array}$ & 1.03 & $\begin{array}{c}0.7 \\
(+/-0.0)\end{array}$ & 1.3 & $\begin{array}{c}1.4 \\
(+/-0.2)\end{array}$ \\
\hline $\operatorname{iv}(c)$ & $\begin{array}{l}\mathrm{Au} / \mathrm{YSZ} \text { nanofiber/ } \mathrm{Bi}_{2} \mathrm{O}_{3}-\mathrm{YSZ}, \mathrm{Bi} \\
\left(\mathrm{NO}_{3}\right)_{3} \text { and } \mathrm{YSZ} \text { nanofibers sintered } \\
\text { at } 1100{ }^{\circ} \mathrm{C} \text {, Au sintered at } 850{ }^{0} \mathrm{C}\end{array}$ & 1.97 & $\begin{array}{c}0.9 \\
(+/-0.1)\end{array}$ & 18.2 & $\begin{array}{c}1.7 \\
(+/-0.1)\end{array}$ \\
\hline
\end{tabular}

Sample (iii) which has a mixture of $\mathrm{Bi}_{2} \mathrm{O}_{3}$ and $\mathrm{YSZ}$ nanofibers shows the lowest $\mathrm{R}_{\mathrm{s}}$ value for these samples (Table 2.9). As discussed above, melting of YSZ nanofibers in the presence of $\mathrm{Bi}_{2} \mathrm{O}_{3}$ which results in a "roughened YSZ surface" might be the reason for this relatively low $R_{s}$ value. $R_{s}$ value for sample iv (a) is higher than for samples iv (b) and iv(c). Possibly, the Au current collector did not sinter well onto the YSZ nanofiber cathode at $700{ }^{\circ} \mathrm{C}$.As same as for the series resistance, sample (iii) shows the lowest $R_{p}$ value at 800 ${ }^{0}$ C. Sample iv (c) shows an unusually high $R_{p}$ value compared to samples iv (a) and iv (b).

\subsubsection{Ag current collectors on YSZ nanofiber cathodes}

Cells characterized:

v. $\mathrm{Ag} / \mathrm{YSZ}$ nanofiber/ $\mathrm{Bi}_{2} \mathrm{O}_{3}$-YSZ: YSZ nanofiber electrodes were painted on $\mathrm{Bi}_{2} \mathrm{O}_{3}$ deposited YSZ substrates and sintered at $850{ }^{\circ} \mathrm{C}$. Then, Ag paint was applied on top of the YSZ nanofiber electrodes and sintered again at $800{ }^{0} \mathrm{C}$.

vi. Ag/YSZ nanofiber (thin)/ HF etched YSZ: A YSZ pellet was etched with Hydrofluoric acid to roughen the surface and thin YSZ nanofiber electrodes were 
painted on this etched region and sintered at $800{ }^{\circ} \mathrm{C}$. Then, $\mathrm{Ag}$ paint was applied on top of the YSZ nanofiber electrodes and sintered again at $700{ }^{\circ} \mathrm{C}$.

vii. $\quad \mathrm{Ag} / \mathrm{YSZ}$ nanofiber (thin) /YSZ: Thin YSZ nanofiber electrodes were painted on bare YSZ electrolyte surfaces and sintered at $1300{ }^{\circ} \mathrm{C}$. Then, Ag paint was applied on top of the YSZ nanofiber electrodes and sintered again at $700{ }^{\circ} \mathrm{C}$.

viii. $\mathrm{Ag} / \mathrm{YSZ}$ nanofiber (1 tape thick) /YSZ: YSZ nanofiber electrodes (thickness of the tape which was used to define the electrode area) were painted on bare YSZ electrolyte surfaces and sintered at $1300{ }^{\circ} \mathrm{C}$. Then, Ag paint was applied on top of the YSZ nanofiber electrodes and sintered again at $800{ }^{\circ} \mathrm{C}$.

ix. $\quad \mathrm{Ag} / \mathrm{YSZ}$ nanofiber (1 tape thick) /YSZ-half cell: YSZ nanofiber electrodes (thickness of the tape used to define the electrode area) were painted on one side of bare YSZ electrolyte surfaces and sintered at $1300{ }^{\circ} \mathrm{C}$. Then, Ag paint was applied on top of the YSZ nanofiber electrode and on the opposite side of the electrode and sintered again at $800{ }^{\circ} \mathrm{C}$.

x. Ag/ YSZ nanofiber (2 tapes thick) /YSZ-half cell: Thick YSZ nanofiber electrodes (thickness of 2 tapes used to define the electrode area) were painted on one side of bare YSZ electrolyte surfaces and sintered at $1300{ }^{\circ} \mathrm{C}$. Then, Ag paint was applied on top of the YSZ nanofiber electrode and on the opposite side of the electrode and sintered again at $800{ }^{\circ} \mathrm{C}$.

Note: When the same cell was re-characterized/aged, it is shown with a (") or (") or (")") or ('") and further details are given in the table. Calculated activation energies and only the resistances measured at $800{ }^{\circ} \mathrm{C}$ are presented in tables so that the resistances at the other temperatures can be calculated. Also, it should be noted that the $R_{p}$ values presented for half cells consist of the polarization resistances for both YSZ powder electrode and Ag (counter) electrode.

As we have discussed before, "Sample v" which has $\mathrm{Bi}\left(\mathrm{NO}_{3}\right)_{3}$ in it shows a comparatively low $R_{s}$ value (Table 2.10). However, "Sample vii" which has a thin layer of YSZ nanofibers sintered at $1300{ }^{\circ} \mathrm{C}$ shows the lowest $\mathrm{R}_{\mathrm{s}}$ value. According to the sintering study, YSZ nanofibers sinter well at this temperature without melting down. However, since we 
used a thin nanofiber layer, maybe the Ag current collector was directly in contact with the electrolyte at some places which resulted in a relatively low series resistance.

Table 2.10: Series resistances, polarization resistances and activation energies of YSZ nanofiber cathodes with Ag current collectors.

\begin{tabular}{|c|c|c|c|c|c|}
\hline Sample & Description & $\begin{array}{c}\mathbf{R}_{\mathrm{s}} \\
\left(\mathrm{Ohmcm}^{2}\right) \\
\text { at } 800^{\circ} \mathrm{C}\end{array}$ & $\begin{array}{c}E_{a}(e V) \\
\text { for } R_{s}\end{array}$ & $\begin{array}{c}\mathbf{R}_{\mathrm{p}} \\
\left(\mathrm{Ohmcm}^{2}\right) \\
\text { at } 800^{0} \mathrm{C}\end{array}$ & $\begin{array}{l}E_{a}(e V) \\
\text { for } R_{p}\end{array}$ \\
\hline $\mathrm{v}$ & $\begin{array}{l}\mathrm{Ag} / \mathrm{YSZ} \text { nanofiber/ } \mathrm{Bi}_{2} \mathrm{O}_{3}-\mathrm{YSZ}, \mathrm{Bi} \\
\left(\mathrm{NO}_{3}\right)_{3} \text { sintered at } 850{ }^{0} \mathrm{C}, \mathrm{YSZ} \\
\text { nanofibers sintered at } 850{ }^{\circ} \mathrm{C}, \mathrm{Ag} \\
\text { sintered at } 800{ }^{\circ} \mathrm{C}\end{array}$ & 1.82 & $\begin{array}{c}1.3 \\
(+/-0.1)\end{array}$ & 0.22 & $\begin{array}{c}1.9 \\
(+/-0.1)\end{array}$ \\
\hline vi & $\begin{array}{l}\mathrm{Ag} / \mathrm{YSZ} \text { nanofiber (thin)/ } \mathrm{HF} \text { etched } \\
\mathrm{YSZ} \text {, YSZ nanofibers sintered at } \\
800{ }^{\circ} \mathrm{C} \text {, Ag sintered at } 700{ }^{\circ} \mathrm{C}\end{array}$ & 3.17 & $\begin{array}{c}0.9 \\
(+/-0.1)\end{array}$ & 3.19 & $\begin{array}{c}1.1 \\
(+/-0.1)\end{array}$ \\
\hline vii & $\begin{array}{l}\mathrm{Ag} / \text { thin YSZ nanofiber/YSZ, YSZ } \\
\text { nanofibers sintered at } 1300{ }^{\circ} \mathrm{C}, \mathrm{Ag} \\
\text { sintered at } 700{ }^{\circ} \mathrm{C}\end{array}$ & 0.61 & $\begin{array}{c}1.0 \\
(+/-0.0)\end{array}$ & 0.34 & $\begin{array}{c}1.2 \\
(+/-0.0)\end{array}$ \\
\hline viii(a) & $\begin{array}{l}\mathrm{Ag} / \mathrm{YSZ} \text { nanofiber (1 tape thick) } \\
\text { /YSZ, YSZ nanofibers sintered at } \\
1300{ }^{0} \mathrm{C}, \mathrm{Ag} \text { sintered at } 800{ }^{0} \mathrm{C} \text {, } \\
\text { heating }\end{array}$ & 2.61 & $\begin{array}{c}1.0 \\
(+/-0.0)\end{array}$ & 6.56 & $\begin{array}{c}0.7 \\
(+/-0.1)\end{array}$ \\
\hline viii(a)' & $\begin{array}{l}\mathrm{Ag} / \mathrm{YSZ} \text { nanofiber }(1 \text { tape thick }) \\
/ \mathrm{YSZ}, \mathrm{YSZ} \text { nanofibers sintered at } \\
1300{ }^{0} \mathrm{C}, \mathrm{Ag} \text { sintered at } 800{ }^{0} \mathrm{C}, \\
\text { cooling }\end{array}$ & 2.6 & $\begin{array}{c}1.0 \\
(+/-0.0)\end{array}$ & 6.88 & $\begin{array}{c}0.9 \\
(+/-0.0)\end{array}$ \\
\hline viii(a)" & $\begin{array}{l}\mathrm{Ag} / \mathrm{YSZ} \text { nanofiber (1 tape thick) } \\
/ \mathrm{YSZ} \text {, YSZ nanofibers sintered at } \\
1300{ }^{\circ} \mathrm{C} \text {, Ag sintered at } 800{ }^{\circ} \mathrm{C} \text {, aged } \\
\sim 24 \mathrm{hrs} \text {, heating }\end{array}$ & 2.62 & $\begin{array}{c}1.0 \\
(+/-0.0)\end{array}$ & 6.91 & $\begin{array}{c}0.6 \\
(+/-0.1)\end{array}$ \\
\hline viii(a)", & $\begin{array}{l}\mathrm{Ag} / \mathrm{YSZ} \text { nanofiber (1 tape thick) } \\
/ \mathrm{YSZ} \text {, YSZ nanofibers sintered at } \\
1300{ }^{\circ} \mathrm{C} \text {, Ag sintered at } 800{ }^{\circ} \mathrm{C} \text {, aged } \\
\sim 24 \mathrm{hrs} \text {, cooling }\end{array}$ & 2.64 & $\begin{array}{c}1.0 \\
(+/-0.1)\end{array}$ & 7.18 & $\begin{array}{c}0.8 \\
(+/-0.0)\end{array}$ \\
\hline viii(a),",' & $\begin{array}{l}\mathrm{Ag} / \mathrm{YSZ} \text { nanofiber (1 tape thick) } \\
/ \mathrm{YSZ} \text {, YSZ nanofibers sintered at } \\
1300{ }^{\circ} \mathrm{C} \text {, Ag sintered at } 800{ }^{\circ} \mathrm{C} \text {, aged } \\
\text { another } \sim 24 \mathrm{hrs} \text {, heating }\end{array}$ & 2.76 & $\begin{array}{c}0.9 \\
(+/-0.0)\end{array}$ & 7.15 & $\begin{array}{c}0.6 \\
(+/-0.1)\end{array}$ \\
\hline ix(a) & $\begin{array}{l}\mathrm{Ag} / \mathrm{YSZ} \text { nanofiber (1 tape thick) } \\
\text { /YSZ-half cell, YSZ nanofibers } \\
\text { sintered at } 1300{ }^{\circ} \mathrm{C}, \mathrm{Ag} \text { sintered at } \\
800{ }^{\circ} \mathrm{C} \text {, heating }\end{array}$ & 1.28 & $\begin{array}{c}0.8 \\
(+/-0.0)\end{array}$ & 6.86 & - \\
\hline ix(a)' & $\begin{array}{l}\mathrm{Ag} / \mathrm{YSZ} \text { nanofiber (1 tape thick) } \\
\text { /YSZ-half cell, YSZ nanofibers } \\
\text { sintered at } 1300{ }^{0} \mathrm{C}, \mathrm{Ag} \text { sintered at } \\
800{ }^{0} \mathrm{C} \text {, cooling }\end{array}$ & 1.29 & $\begin{array}{c}0.8 \\
(+/-0.0)\end{array}$ & 7.24 & - \\
\hline
\end{tabular}




\begin{tabular}{|c|c|c|c|c|c|}
\hline ix(a)" & $\begin{array}{l}\mathrm{Ag} / \mathrm{YSZ} \text { nanofiber (1 tape thick) } \\
/ \text { YSZ-half cell, YSZ nanofibers } \\
\text { sintered at } 1300{ }^{\circ} \mathrm{C} \text {, Ag sintered at } \\
800{ }^{\circ} \mathrm{C} \text {, aged } \sim 24 \mathrm{hrs} \text {, heating }\end{array}$ & 1.31 & $\begin{array}{c}0.8 \\
(+/-0.0)\end{array}$ & 6.53 & - \\
\hline ix(a)", & $\begin{array}{l}\mathrm{Ag} / \mathrm{YSZ} \text { nanofiber (1 tape thick) } \\
/ \text { YSZ-half cell, YSZ nanofibers } \\
\text { sintered at } 1300{ }^{\circ} \mathrm{C} \text {, Ag sintered at } \\
800{ }^{\circ} \mathrm{C} \text {, aged } \sim 24 \mathrm{hrs} \text {, cooling }\end{array}$ & 1.31 & $\begin{array}{c}0.9 \\
(+/-0.0)\end{array}$ & 6.8 & - \\
\hline$x(a)$ & $\begin{array}{l}\mathrm{Ag} / \mathrm{YSZ} \text { nanofiber (2 tapes thick) } \\
\text { /YSZ-half cell, YSZ nanofibers } \\
\text { sintered at } 1300{ }^{\circ} \mathrm{C}, \mathrm{Ag} \text { sintered at } \\
800{ }^{\circ} \mathrm{C} \text {, heating }\end{array}$ & 2.57 & $\begin{array}{c}0.8 \\
(+/-0.0)\end{array}$ & 15.49 & - \\
\hline$x(a)^{\prime}$ & $\begin{array}{l}\mathrm{Ag} / \text { YSZ nanofiber ( } 2 \text { tapes thick) } \\
\text { /YSZ-half cell, YSZ nanofibers } \\
\text { sintered at } 1300{ }^{0} \mathrm{C}, \mathrm{Ag} \text { sintered at } \\
800{ }^{\circ} \mathrm{C} \text {, cooling }\end{array}$ & 2.57 & $\begin{array}{c}0.8 \\
(+/-0.0)\end{array}$ & 13.92 & - \\
\hline$x(a)^{\prime \prime}$ & $\begin{array}{l}\mathrm{Ag} / \mathrm{YSZ} \text { nanofiber ( } 2 \text { tapes thick) } \\
/ \text { YSZ-half cell, YSZ nanofibers } \\
\text { sintered at } 1300{ }^{\circ} \mathrm{C} \text {, Ag sintered at } \\
800{ }^{\circ} \mathrm{C} \text {, aged } \sim 24 \mathrm{hrs} \text {, heating }\end{array}$ & 2.57 & $\begin{array}{c}0.8 \\
(+/-0.0)\end{array}$ & 10.59 & - \\
\hline$x(a), "$, & $\begin{array}{l}\mathrm{Ag} / \mathrm{YSZ} \text { nanofiber ( } 2 \text { tapes thick) } \\
/ \mathrm{YSZ} \text {-half cell, YSZ nanofibers } \\
\text { sintered at } 1300{ }^{0} \mathrm{C} \text {, Ag sintered at } \\
800{ }^{\circ} \mathrm{C} \text {, aged } \sim 24 \mathrm{hrs} \text {, cooling }\end{array}$ & 2.57 & $\begin{array}{c}0.8 \\
(+/-0.1)\end{array}$ & 10.67 & - \\
\hline
\end{tabular}

In "Sample vi", we tried to sinter the YSZ nanofibers at a lower temperature $\left(800{ }^{\circ} \mathrm{C}\right)$ by creating a roughened YSZ electrolyte surface by HF etching. However, the high $\mathrm{R}_{\mathrm{s}}$ value at $800{ }^{0} \mathrm{C}$ suggests that the nanofibers did not sinter well. Sample viii (YSZ nanofiber symmetrical cell) was characterized after aging it at $700{ }^{0} \mathrm{C}$. Since the $\mathrm{R}_{\mathrm{s}}$ values did not drastically change with aging, the electrodes and the current collectors show good adhesion.

In "Samples ix and x", YSZ nanofiber half cells were used instead of symmetrical cells. It should be noted that the $R_{p}$ values presented for half cells consist of the polarization resistances for both YSZ nanofiber electrode and Ag (counter) electrode. Since we were not able to record impedance spectra using PAR system, we did not have any means of separating the resistances for the nanofiber cathode and the Ag cathode. "Sample x" had a YSZ nanofiber layer which is as twice as thick as the nanofiber layer in "Sample ix". Therefore, the $\mathrm{R}_{\mathrm{s}}$ value (at $800{ }^{0} \mathrm{C}$ ) for "Sample $\mathrm{x}$ " is $\sim 2$ times higher than the value for "Sample ix". Aging study of these samples also shows that the cathodes were very stable over the tested time period. 
As we have observed before, "Sample v" which has $\mathrm{Bi}\left(\mathrm{NO}_{3}\right)_{3}$ in it shows the lowest $\mathrm{R}_{\mathrm{p}}$ value. "Sample vii" also shows a very low $R_{p}$ value and a comparatively high activation energy which might be a result of the reasons discussed before for $\mathrm{R}_{\mathrm{s}}$ values. Aging study of "Samples viii, ix and x" shows the cathodes were very stable over time. Also, when "Samples ix and x" are compared, it can be seen that as same as $R_{s}$ values, $R_{p}$ values also increase with the thickness of the cathode.

\subsubsection{Ag current collectors on YSZ powder cathodes}

\section{Cells characterized:}

xi. $\quad \mathrm{Ag} / \mathrm{YSZ}$ powder (1 tape thick) /YSZ: YSZ powder (paste of YSZ powder and graphite) electrodes (thickness of a tape used to define the electrode area) were painted on bare YSZ electrolyte surfaces and sintered at $1300{ }^{0} \mathrm{C}$. Then, Ag paint was applied on top of the YSZ powder electrodes and sintered again at $800{ }^{\circ} \mathrm{C}$.

xii. $\quad$ Ag/ YSZ powder (1 tape thick) /YSZ-half cell: YSZ powder (paste of YSZ powder and graphite) electrodes (thickness of a tape used to define the electrode area) were painted on one side of bare YSZ electrolyte surfaces and sintered at $1300{ }^{0} \mathrm{C}$. Then, Ag paint was applied on top of the YSZ powder electrode and on the opposite side of the electrode and sintered again at $800{ }^{0} \mathrm{C}$.

Note: When the same cell was re-characterized/aged, it is shown with a (') or (') or (")') and further details are given in the table. Calculated activation energies and only the resistances measured at $800{ }^{\circ} \mathrm{C}$ are presented in tables so that the resistances at the other temperatures can be calculated. Also, it should be noted that the $R_{p}$ values presented for half cells consist of the polarization resistances for both YSZ powder electrode and Ag (counter) electrode.

When "Samples ix, x (Table 2.10), xi and xii (Table 2.11)" are compared, it can be seen that the activation energies for conductivity across the cell $(0.7-0.9 \mathrm{eV})$ are in the same range for both the YSZ powder cathode and the YSZ nanofiber cathode. Aging study shows that the YSZ powder cathodes also are stable over time. 
When the $\mathrm{R}_{\mathrm{s}}$ values of "Samples viii and xi" are compared, it can be seen that "Sample xi" has a higher $\mathrm{R}_{\mathrm{s}}$ value than the "Sample viii", even though both of them had "1 tape thick" YSZ powder and nanofibers respectively. However, the SEM images of the cross sections of these cells showed that the YSZ nanofibers form a comparatively thin electrode $(\sim 30$ um) than the YSZ powder electrode $(\sim 60 \mathrm{um})$, after sintering at $1300{ }^{0} \mathrm{C}$. In both structures, it is clear that the porous YSZ structure exhibits a substantial Ohmic resistance in the absence of a percolating electrode network inside the porous structure.

Table 2.11: Series and Polarization resistances of YSZ powder cathodes with Ag current collectors.

\begin{tabular}{|c|c|c|c|c|c|}
\hline Sample & Description & $\begin{array}{c}\mathbf{R}_{\mathrm{s}} \\
(\mathrm{Ohmcm} 2) \\
\text { at } 800^{\circ} \mathrm{C} \\
\end{array}$ & $\begin{array}{c}E_{a}(e V) \\
\text { for } R_{s}\end{array}$ & $\begin{array}{c}R_{p} \\
(O h m c m 2) \\
\text { at } 800^{\circ} \mathrm{C}\end{array}$ & $\begin{array}{c}E_{a}(e V) \\
\text { for } R_{p}\end{array}$ \\
\hline xi(a) & $\begin{array}{l}\mathrm{Ag} / \mathrm{YSZ} \text { powder }(1 \text { tape thick }) \\
/ \mathrm{YSZ}, \mathrm{YSZ} \text { powder sintered at } \\
1300{ }^{\circ} \mathrm{C}, \mathrm{Ag} \text { sintered at } 800{ }^{\circ} \mathrm{C} \text {, } \\
\text { heating }\end{array}$ & 5.94 & $\begin{array}{c}0.7 \\
(+/-0.1)\end{array}$ & 6.25 & $\begin{array}{c}0.9 \\
(+/-0.0)\end{array}$ \\
\hline xi(a)' & $\begin{array}{l}\mathrm{Ag} / \text { YSZ powder (1 tape thick) } \\
/ \mathrm{YSZ}, \mathrm{YSZ} \text { powder sintered at } \\
1300{ }^{\circ} \mathrm{C}, \mathrm{Ag} \text { sintered at } 800{ }^{\circ} \mathrm{C} \text {, } \\
\text { cooling }\end{array}$ & 6.09 & $\begin{array}{c}0.7 \\
(+/-0.1)\end{array}$ & 6.32 & $\begin{array}{c}1.1 \\
(+/-0.0)\end{array}$ \\
\hline xi(a)" & $\begin{array}{l}\mathrm{Ag} / \text { YSZ powder }(1 \text { tape thick }) \\
/ \mathrm{YSZ}, \mathrm{YSZ} \text { powder sintered at } \\
1300{ }^{\circ} \mathrm{C}, \mathrm{Ag} \text { sintered at } 800{ }^{\circ} \mathrm{C} \text {, } \\
\text { aged } \sim 72 \mathrm{hrs} \text {, heating }\end{array}$ & 6.35 & $\begin{array}{c}0.9 \\
(+/-0.0)\end{array}$ & 5.72 & $\begin{array}{c}1.0 \\
(+/-0.0)\end{array}$ \\
\hline xi(a)",' & $\begin{array}{l}\mathrm{Ag} / \mathrm{YSZ} \text { powder }(1 \text { tape thick }) \\
/ \mathrm{YSZ}, \mathrm{YSZ} \text { powder sintered at } \\
1300{ }^{\circ} \mathrm{C}, \mathrm{Ag} \text { sintered at } 800{ }^{\circ} \mathrm{C} \text {, } \\
\text { aged } \sim 72 \mathrm{hrs} \text {, cooling }\end{array}$ & 7.29 & $\begin{array}{c}0.9 \\
(+/-0.0)\end{array}$ & 5.31 & $\begin{array}{c}1.1 \\
(+/-0.0)\end{array}$ \\
\hline xii(a) & $\begin{array}{l}\mathrm{Ag} / \text { YSZ powder (1 tape thick) } \\
\text { /YSZ-half-cell, YSZ powder } \\
\text { sintered at } 1300{ }^{\circ} \mathrm{C}, \mathrm{Ag} \text { sintered } \\
\text { at } 800{ }^{\circ} \mathrm{C} \text {, heating }\end{array}$ & 2.03 & $\begin{array}{c}0.8 \\
(+/-0.0)\end{array}$ & 8.43 & - \\
\hline xii(a)' & $\begin{array}{l}\mathrm{Ag} / \text { YSZ powder (1 tape thick) } \\
\text { /YSZ-half-cell, YSZ powder } \\
\text { sintered at } 1300{ }^{\circ} \mathrm{C}, \mathrm{Ag} \text { sintered } \\
\text { at } 800{ }^{\circ} \mathrm{C} \text {, cooling }\end{array}$ & 2.03 & $\begin{array}{c}0.9 \\
(+/-0.0)\end{array}$ & 8.51 & - \\
\hline xii(a)", & $\begin{array}{l}\mathrm{Ag} / \text { YSZ powder (1 tape thick) } \\
\text { /YSZ-half-cell, YSZ powder } \\
\text { sintered at } 1300{ }^{0} \mathrm{C}, \mathrm{Ag} \text { sintered } \\
\text { at } 800{ }^{\circ} \mathrm{C} \text {, aged } \sim 24 \mathrm{hrs} \text {, heating }\end{array}$ & 2.11 & $\begin{array}{c}0.8 \\
(+/-0.0)\end{array}$ & 8.24 & - \\
\hline xii(a)"', & $\begin{array}{l}\mathrm{Ag} / \text { YSZ powder (1 tape thick) } \\
\text { /YSZ-half-cell, YSZ powder } \\
\text { sintered at } 1300{ }^{\circ} \mathrm{C}, \mathrm{Ag} \text { sintered } \\
\text { at } 800{ }^{\circ} \mathrm{C} \text {, aged } \sim 24 \mathrm{hrs} \text {, cooling }\end{array}$ & 2.11 & $\begin{array}{c}0.8 \\
(+/-0.0)\end{array}$ & 8.28 & - \\
\hline
\end{tabular}




\subsubsection{Ag current collectors on LSM infiltrated YSZ cathodes}

Here we have tested only 2 half cells using the PAR system as a preliminary study. Note that the $R_{p}$ values presented for these half cells consist of the polarization resistances for both LSM infiltrated YSZ electrode and Ag (counter) electrode. The infiltration work will be continued using the Solartron system and symmetrical cells which will be discussed in greater detail in Chapter 03.

Cells characterized:

xiii. $\quad \mathrm{Ag} / \mathrm{LSM}$ infiltrated YSZ nanofiber (2 tapes thick) /YSZ-half cell: YSZ nanofiber electrodes (thickness of 2 tapes used to define the electrode area) were painted on one side of bare YSZ electrolyte surfaces and sintered at $1300{ }^{\circ} \mathrm{C}$. Then, organic LSM (30\%) was infiltrated through the porous YSZ electrode and sintered at 900 ${ }^{0} \mathrm{C}$. Finally, Ag paint was applied on top of the YSZ nanofiber electrode and on the opposite side of the electrode and sintered again at $800{ }^{\circ} \mathrm{C}$.

xiv. Ag/LSM infiltrated YSZ powder (1 tape thick)/YSZ-half cell: YSZ powder electrodes (thickness of a tape used to define the electrode area) were painted on one side of bare YSZ electrolyte surfaces and sintered at $1300{ }^{\circ} \mathrm{C}$. Then, organic LSM (30\%) was infiltrated through the porous YSZ electrode and sintered at 900 ${ }^{0} \mathrm{C}$. Finally, Ag paint was applied on top of the YSZ powder electrode and on the opposite side of the electrode and sintered again at $800{ }^{\circ} \mathrm{C}$.

Note: When the same cell was re-characterized/aged, it is shown with a (") or (") or (")) and further details are given in the table. Calculated activation energies and only the resistances measured at $800{ }^{\circ} \mathrm{C}$ are presented in tables so that the resistances at the other temperatures can be calculated.

In this section we have compared an LSM infiltrated YSZ nanofiber cathode with an LSM infiltrated YSZ cathode. Since the SEM images showed that the sintered YSZ nanofiber cathodes have a lesser thickness $(\sim 30 \mu \mathrm{m})$ than the sintered powder cathodes $(\sim 60 \mu \mathrm{m})$, we used a "2 tapes thick" YSZ nanofiber layer so that we can directly compare the performances of the 2 cells. 
Table 2.12: Series resistances, polarization resistances and activation energies of LSM infiltrated YSZ cathodes with Ag current collectors.

\begin{tabular}{|c|c|c|c|c|}
\hline Sample & Description & $\begin{array}{c}\mathbf{R}_{\mathrm{s}} \\
\left(\mathrm{Ohmcm}^{2}\right) \\
\text { at } 800^{\circ} \mathrm{C}\end{array}$ & $\begin{array}{c}E_{a}(e V) \\
\text { for } R_{s}\end{array}$ & $\begin{array}{c}\mathbf{R}_{\mathrm{p}} \\
\left(\mathrm{Ohmcm}^{2}\right) \\
\text { at } 800^{0} \mathrm{C}\end{array}$ \\
\hline xiii(a) & $\begin{array}{l}\mathrm{Ag} / \mathrm{LSM} \text { infiltrated YSZ nanofiber } \\
(2 \text { tapes thick) /YSZ-half cell, YSZ } \\
\text { nanofibers sintered at } 1300{ }^{\circ} \mathrm{C} \text {, } \\
\text { LSM sintered at } 900{ }^{\circ} \mathrm{C}, \mathrm{Ag} \text { sintered } \\
\text { at } 800{ }^{\circ} \mathrm{C} \text {, heating }\end{array}$ & 0.64 & $\begin{array}{c}0.5 \\
(+/-0.0)\end{array}$ & 1.3 \\
\hline xiii(a)' & $\begin{array}{l}\mathrm{Ag} / \mathrm{LSM} \text { infiltrated YSZ nanofiber } \\
(2 \text { tapes thick) /YSZ-half cell, YSZ } \\
\text { nanofibers sintered at } 1300{ }^{0} \mathrm{C} \text {, } \\
\text { LSM sintered at } 900{ }^{\circ} \mathrm{C}, \mathrm{Ag} \text { sintered } \\
\text { at } 800^{\circ} \mathrm{C} \text {, cooling }\end{array}$ & 0.63 & $\begin{array}{c}0.6 \\
(+/-0.0)\end{array}$ & 1.3 \\
\hline xiii(a)" & $\begin{array}{l}\mathrm{Ag} / \mathrm{LSM} \text { infiltrated YSZ nanofiber } \\
(2 \text { tapes thick) } / \mathrm{YSZ} \text {-half cell, YSZ } \\
\text { nanofibers sintered at } 1300{ }^{0} \mathrm{C} \text {, } \\
\mathrm{LSM} \text { sintered at } 900{ }^{\circ} \mathrm{C} \text {, Ag sintered } \\
\text { at } 800^{\circ} \mathrm{C} \text {, aged } \sim 24 \mathrm{hrs} \text {, heating }\end{array}$ & 0.64 & $\begin{array}{c}0.6 \\
(+/-0.0)\end{array}$ & 1.35 \\
\hline xiii(a)"," & $\begin{array}{l}\mathrm{Ag} / \mathrm{LSM} \text { infiltrated YSZ nanofiber } \\
(2 \text { tapes thick) /YSZ-half cell, YSZ } \\
\text { nanofibers sintered at } 1300{ }^{0} \mathrm{C} \text {, } \\
\text { LSM sintered at } 900{ }^{\circ} \mathrm{C} \text {, Ag sintered } \\
\text { at } 800^{\circ} \mathrm{C} \text {, aged } \sim 24 \mathrm{hrs} \text {, cooling }\end{array}$ & 0.64 & $\begin{array}{c}0.6 \\
(+/-0.0)\end{array}$ & 1.35 \\
\hline xiv(a) & $\begin{array}{l}\mathrm{Ag} / \mathrm{LSM} \text { infiltrated YSZ powder }(1 \\
\text { tape thick)/YSZ-half cell, YSZ } \\
\text { powder sintered at } 1300{ }^{\circ} \mathrm{C} \text {, LSM } \\
\text { sintered at } 900{ }^{0} \mathrm{C}, \mathrm{Ag} \text { sintered at } \\
800{ }^{\circ} \mathrm{C} \text {, heating }\end{array}$ & 0.8 & $\begin{array}{c}0.7 \\
(+/-0.1)\end{array}$ & 1.78 \\
\hline xiv(a)' & $\begin{array}{l}\text { Ag/LSM infiltrated YSZ powder }(1 \\
\text { tape thick)/YSZ-half cell, YSZ } \\
\text { powder sintered at } 1300{ }^{\circ} \mathrm{C} \text {, LSM } \\
\text { sintered at } 900{ }^{0} \mathrm{C}, \mathrm{Ag} \text { sintered at } \\
800{ }^{\circ} \mathrm{C} \text {, cooling }\end{array}$ & 0.8 & $\begin{array}{c}0.6 \\
(+/-0.0)\end{array}$ & 1.8 \\
\hline $\operatorname{xiv}(a) "$ & $\begin{array}{l}\text { Ag/LSM infiltrated YSZ powder (1 } \\
\text { tape thick)/YSZ-half cell, YSZ } \\
\text { powder sintered at } 1300{ }^{\circ} \mathrm{C} \text {, LSM } \\
\text { sintered at } 900{ }^{0} \mathrm{C} \text {, Ag sintered at } \\
800{ }^{\circ} \mathrm{C} \text {, aged } \sim 72 \mathrm{hrs} \text {, heating }\end{array}$ & 0.8 & $\begin{array}{c}0.6 \\
(+/-0.0)\end{array}$ & 1.49 \\
\hline $\operatorname{xiv}(a) "$, & $\begin{array}{l}\text { Ag/LSM infiltrated YSZ powder (1 } \\
\text { tape thick)/YSZ-half cell, YSZ } \\
\text { powder sintered at } 1300{ }^{\circ} \mathrm{C} \text {, LSM } \\
\text { sintered at } 900{ }^{0} \mathrm{C} \text {, Ag sintered at } \\
800{ }^{\circ} \mathrm{C} \text {, aged } \sim 72 \mathrm{hrs} \text {, cooling }\end{array}$ & 0.8 & $\begin{array}{c}0.6 \\
(+/-0.0)\end{array}$ & 1.48 \\
\hline
\end{tabular}

When the porous YSZ nanofiber or YSZ powder scaffold was infiltrated with LSM, $R_{s}$ and $R_{p}$ values drastically decreased as expected (Table 2.12). When YSZ ionic conductor and LSM electronic conductor together are in contact with air (inside the porous cathode), the number of triple phase boundaries increase resulting in lower $\mathrm{R}_{\mathrm{p}}$ values. $\mathrm{R}_{\mathrm{s}}$ values $\sim 0.7$ 
$\mathrm{Ohmcm}^{2}$ suggest that there is good connectivity from the YSZ electrolyte through the LSM infiltrated YSZ electrode to the current collecting Ag layer. For both cells, activation energies for conductivity across the cell $(0.5-0.7 \mathrm{eV})$ are in the same range. However, both $R_{s}$ and $R_{p}$ values measured at $800{ }^{\circ} \mathrm{C}$ are slightly lower for LSM infiltrated nanofiber cathodes. Also, the short aging study shows that these cells performed stably over time.

\subsection{Summary}

The sintering study showed how the YSZ nanofiber morphology changes with the sintering temperature. Sintering starts at $1300{ }^{\circ} \mathrm{C}$ and melting of the nanoparticles occurs at higher temperatures. Compared to $\mathrm{Pt}$ and $\mathrm{Au}, \mathrm{Ag}$ acted as a better current collector for porous YSZ cathodes. As expected, infiltrating the YSZ cathodes with LSM improved their performance.

\subsection{Conclusion}

Based on the SEM images of the "sintering study", we can conclude that $\mathrm{Bi}_{2} \mathrm{O}_{3}$ is not a suitable sintering aid for YSZ nanofibers since this composition destroys the YSZ nanofibers and results in a dense YSZ scaffold. Therefore, we chose $1300{ }^{\circ} \mathrm{C}$ as the sintering temperature for YSZ nanofibers without any sintering aid. Since the preliminary results achieved for these LSM infiltrated YSZ cathodes look promising, continuation of this work on the symmetrical LSM infiltrated YSZ scaffolds will be presented and discussed in detail in Chapter 03. 


\subsection{References}

1. Sarikaya A., Petrovsky V., Dogan F., Journal of Materials Research, 2012, 27 (15), 2024-2029

2. Badwal S., Solid State Ionics, 1992, 52, 23-32

3. $\quad$ Adler S., Chemical Reviews, 2004, 104 (10), 4791-4843

4. Introduction to Solid Oxide Fuel Cell Button Cell Testing, http://w.fchea.org/core/import/PDFs/Technical\%20Resources/SOFCFGButtonCellTesting-07-015.pdf (10/21/2014)

5. Harris D., Quantitative Chemical Analysis, $6^{\text {th }}$ edition, W.H. Freeman and company, 2003, ISBN 0-7167-4464-3, 69-71

6. Barbucci A., Bozzo R., Cerisola G., Costamagna P., Electrochimica Acta, 2002, 47, 2183-2188

7. Badwal S., Journal of Materials Science, 1984, 19, 1767-1776

8. Verkerk M., Burggraaf A., Journal of Electrochemical Society, 1983, 130(1), 78-84

9. Vladikova D., Stoynov Z., Barbucci A., Viviani M., Carpanese P., Kilner J., Skinner S., Rudkin R., Electrochimica Acta, 2008, 53, 7491-7499

10. Nielsen J., Jacobsen T., Solid State Ionics, 2008, 178, 1769-1776

11. Guo Y., Liu Y., Cai R., Chen D., Ran R., Shao Z., International Journal of Hydrogen Energy, 2012, 37 (19), 14492-14500

12. Horita T., Yamaji K., Sakai N., Xiong Y., Kato T., Yokokawa H., Kawada T., Journal of Power Sources, 2002, 106, 224-230

13. Jiang S., Journal of Materials Science, 2008, 43 (21), 6799-6833

14. Lai T., Barnett S., Journal of Power Sources, 2007, 164 (2), 742-745

15. Wachsman E.D., Armstrong E.N., Electrochemical Society Transactions, 2011, $35,1955-1963$

16. Zhi M., Electrochemical and Microstructural Analysis of SOFC electrodes, Dissertation, West Virginia University, 2010

17. Bard A.J., Faulkner L.R., Electrochemical methods-Fundamentals and applications., $2^{\text {nd }}$ Edition, John Wiley and Sons inc., 2000, 7

18. Jiang S., International Journal of Hydrogen Energy, 2012, 37, 449-470 
19. Zhi M., Mariani N., Gemmen R., Gerdes K.,Wu N., Energy \& Environmental Science, 2011, 4, 417-420

20. Dong Z., Kennedy S., Wu Y., Journal of Power Sources, 2011, 196, 4886-4904

21. Kim H., Low Temperature Sintering of Nanosized Ceramic Powder: YSZ-Bismuth Oxide System, Dissertation, Ohio State University, 2004

22. Keizr K., Burggraaf A.J., Journal of Materials Science, 1982, 17, 1095-1102 


\section{Chapter 03}

\section{LSM current collectors and LSM infiltrated YSZ scaffolds}

\subsection{Introduction}

The objective of this project is to create a high performing cathode based on a porous YSZ scaffold on a YSZ electrolyte infiltrated with LSM nanoparticles and with a current collector based on larger LSM particles. The polarization resistances and series resistances extracted using impedance data are presented in this chapter. Deconvolution analysis of the impedance spectra for these LSM infiltrated YSZ scaffolds and equivalent circuit fitting is discussed in Chapter 04 - Section 4.4.

As we have discussed before, the electrocatalytic activity of the cathode plays a major role in the overall performance of the SOFC. "Infiltration/impregnation" is a widely investigated technique used for the surface modification of SOFC cathodes [1], [2]. Infiltration technique requires two different sintering steps. First, the porous cathode backbone is sintered at a higher temperature to ensure structural stability and good connectivity between the cathode and the electrolyte, which facilitates the ionic and electronic conductivity [1]. Then, the infiltration solution containing nanoparticles or stoichiometric amounts of metal salt precursors is infiltrated through the cathode backbone and sintered at a much lower temperature. As a result of this lower sintering temperature, nano sized catalyst particles (which results in high active surface area) can be formed inside the porous cathode. Furthermore, the low temperature sintering minimizes unfavorable reactions which lead to undesirable secondary phases and also eliminates delaminating issues due to TEC (thermal expansion coefficient) mismatch [1], [2]. Infiltration is also a cost effective technique since it utilizes a limited amount of the catalyst as opposed to conventional composite cathodes [2].

In order to coat the cathode backbone with sufficient infiltrated material, a multiple number of infiltration steps have to be repeated as shown in Figure 3.1. After the final sintering step, the infiltrated material can either form a continuous thin film or discrete particles on the cathode backbone (Figure 3.2). 


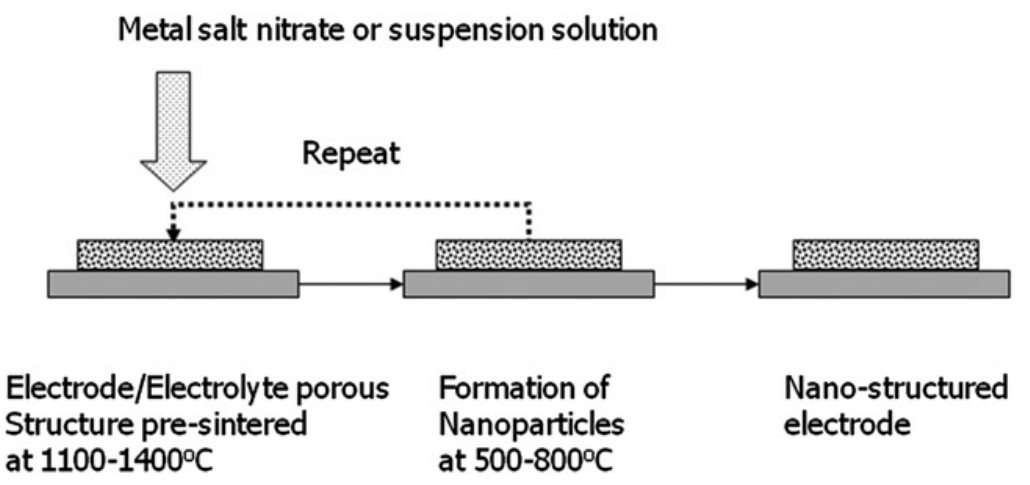

Figure 3.1: Multi step infiltration process [2].
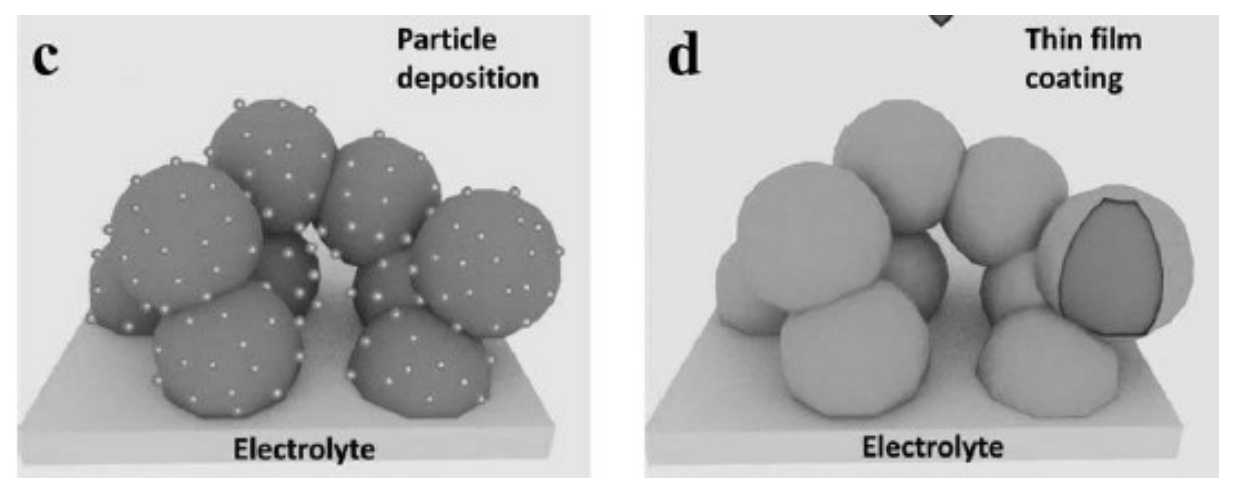

Figure 3.2: Discrete particles (c) or continuous thin film (d) on the cathode backbone [1].

Properties of both the cathode backbone and the infiltration solution are important for a better performing infiltrated cathode. Less viscous infiltration solutions with surfactants/complexing agents have been reported to result in uniform catalyst layers. Porosity, morphology, dimensions and the wetting properties of the cathode backbone also affects the infiltration process and the properties of the resulting SOFC [1], [2].

The small particles generated by the infiltration method present a challenge for current collection. In many SOFC cathodes, larger LSM particles are used to create an effective current collector for the active part of the cathode [3]. Since infiltration was performed with the LSM current collector layer in place, experiments with LSM-graphite powder mixtures were included with the goal of increasing the porosity of the LSM layer. Since long term stability is one of the requirements of practical SOFCs, aging studies were performed on some of the fabricated cells. 


\subsection{Experimental}

This study was carried out in 3 steps. Step 1 was performed to observe the cathode and current collection properties of pure LSM and "mixtures of LSM and graphite". These control experiments provided a baseline of ohmic and polarization resistances for the porous scaffold systems. We used a thin layer of Ag paste on top of the LSM current collector to reduce further the ohmic resistance and to ensure complete current collection using a silver wire contact. In Step 2, we compared the performance of Ag/LSM/YSZ scaffold/YSZ symmetric cells where the YSZ scaffold is based on either YSZ nanofibers or YSZ powder. From these measurements, the ohmic ionic resistance of the scaffold is obtained. In Step 3, we infiltrated the YSZ scaffolds with an organic LSM solution prepared using a method published by Choi et al. [4] and studied the electrochemical performance of $\mathrm{Ag} / \mathrm{LSM} / \mathrm{LSM}$ infiltrated YSZ/YSZ symmetric cells. The organic LSM $(0.1 \mathrm{M})$ solution was prepared by dissolving proper amounts of $\mathrm{La}\left(\mathrm{NO}_{3}\right)_{3} \cdot 6 \mathrm{H}_{2} \mathrm{O}(0.82 \mathrm{~g})$, $\operatorname{Sr}\left(\mathrm{NO}_{3}\right)_{2}(0.10 \mathrm{~g})$ and $\mathrm{Mn}\left(\mathrm{NO}_{3}\right)_{2}(412 \mu \mathrm{L})$ in a mixture of glacial acetic acid $(8.3 \mathrm{~mL})$ and 2-methoxy ethanol (16.7 mL) (1:2) [4].

Commercial LSM powder $\left(\left(\mathrm{La}_{0.8} \mathrm{Sr}_{0.2}\right)_{0.95} \mathrm{MnO}_{3-\delta}\right)$ and $\mathrm{YSZ}$ powder (YSZ8-TC, surface area: $7.4 \mathrm{~m}^{2} / \mathrm{g}$, and YSZ8-N, surface area: $144 \mathrm{~m}^{2} / \mathrm{g}$ )) were obtained from Fuel Cell Materials. Graphite powder ( $\sim 325 \mathrm{mesh})$ was purchased from Alfa Aesar.

A Solartron SI 1287 electrochemical interface and 1252A frequency response analyzer were used to perform the electrochemical characterization at $800{ }^{\circ} \mathrm{C}, 750{ }^{\circ} \mathrm{C}$ and $700{ }^{0} \mathrm{C}$. Some cells were aged at $700{ }^{\circ} \mathrm{C}$ for a certain time period and re-characterized. Impedances were measured using $10 \log$ linear frequencies per decade, starting at $100 \mathrm{kHz}$ and ending at $0.1 \mathrm{~Hz}$ or $0.02 \mathrm{~Hz}$, using a $10 \mathrm{mV} \mathrm{AC}$ amplitude.

\section{Step 1:}

The LSM pastes used for current collectors were prepared as follows.

a) Commercial LSM powder (2 g) was mixed with $\alpha$ - terpineol (1 g) (2:1 by weight) to make the pure LSM paste. 
b) Commercial LSM powder $(0.5 \mathrm{~g})$ was mixed with graphite powder $(0.05 \mathrm{~g})$ (Alfa Aesar, 325 mesh) (10:1 by weight) and $\alpha$-terpineol $(1 \mathrm{~g})$ to make the $10 \% \mathrm{C}$ LSM paste.

c) Commercial LSM powder $(0.3 \mathrm{~g})$ was mixed with graphite powder $(0.3 \mathrm{~g})$ (Alfa Aesar, $325 \mathrm{mesh}$ ) (1:1 by weight) and $\alpha$-terpineol $(1 \mathrm{~g})$ to make the $50 \% \mathrm{C}$-LSM paste.

All these pastes were "ball-milled" using a WIG-L-BUG (borrowed from Dr. Alan Stolzenberg's laboratory). Then, they were painted on YSZ (tape was used to define the thickness of the electrode) electrolytes and sintered at $1200{ }^{0} \mathrm{C}$ for 1 hour to create LSM/YSZ symmetric cells which were electrochemically characterized.

\section{Step 2:}

A YSZ nanofiber paste was prepared by mixing the nanofibers $(0.4 \mathrm{~g})$ (received from Dr.Nick Wu's group) with $\alpha$-terpineol (4 g) (1:10 by weight). A YSZ powder paste was prepared by ball-milling (using WIG-L-BUG) YSZ powder ( $1 \mathrm{~g}$ ) (YSZ8-TC) with graphite powder ( $1 \mathrm{~g})$ and $\alpha$-terpineol ( $2 \mathrm{~g})$ (1:1:2 by weight). Then, these YSZ pastes were painted on YSZ electrolytes and sintered at $1300{ }^{0} \mathrm{C}$ or $1400{ }^{\circ} \mathrm{C}$ for 2 hours. A double sided tape was used to define the area of the electrodes. Therefore, the thickness of the tape $(\sim 100$ $\mu \mathrm{m})$ defined the thickness of the electrode before sintering. After the cells cool down, pure LSM or "LSM- graphite mixture" current collectors were painted on YSZ electrodes and sintered again at $1200{ }^{0} \mathrm{C}$ for 1 hour. Then, these cells were characterized using Ag paste current collectors and Ag wires.

\section{Step 3:}

In addition to the YSZ pastes mentioned in Step 2, the following YSZ pastes were prepared.

a) A different YSZ powder paste was prepared by ball-milling (using WIG-L-BUG) YSZ powder (0.7 g) (YSZ8-N) with graphite powder (0.7 g) (Alfa Aesar, 325 mesh) and $\alpha$-terpineol (1.4 g) (1:1:2 by weight) 
b) A ball-milled YSZ nanofiber paste was prepared by using the WIG-L-BUG to grind the nanofiber paste prepared in Step 2.

Then, as mentioned in Step 2, these YSZ pastes were painted on both sides of YSZ electrolytes (a double sided tape was used to define the area and the thickness of the electrodes before sintering) and sintered at $1300{ }^{0} \mathrm{C}, 1400{ }^{0} \mathrm{C}$ or $1500{ }^{0} \mathrm{C}$. After cooling, pure LSM or "LSM-graphite mixture" current collectors were painted on YSZ electrodes and sintered again at $1200{ }^{0} \mathrm{C}$ for 1 hour. Then, these YSZ scaffolds were infiltrated (through the LSM current collector) with the organic LSM solution [4]. Multiple infiltrations had to be carried out in order to achieve $30 \%$ by weight LSM in each YSZ electrode. In the example shown below, $20 \mu \mathrm{L}$ was infiltrated in 10 infiltration steps $(2 * 1$ $\mu \mathrm{L}$ infiltrated at each step). After each infiltration, the cell was dried at $\sim 150{ }^{0} \mathrm{C}$ to evaporate the solvents. After $\sim 3$ infiltration steps, the cell was heated at $\sim 450{ }^{0} \mathrm{C}$ to decompose the nitrates [5], [6]. Finally, the cell was sintered at $800{ }^{0} \mathrm{C}$ and characterized using Ag paste and Ag wires as contact to the LSM paste layer.

Shown below is an example which shows the weights measured for a $\sim 45 \%$ LSM infiltrated YSZ scaffold.

Weight of the YSZ electrolyte $\quad=466.6 \mathrm{mg}$

Weight of the YSZ electrolyte and YSZ scaffolds on $=468.4 \mathrm{mg}$ both sides

Approximate weight of one YSZ scaffold $=(468.4 \mathrm{mg}-466.6 \mathrm{mg}) / 2$ $=0.9 \mathrm{mg}$

Weight of the cell after infiltrating one YSZ scaffold $=468.8 \mathrm{mg}$ with $20 \mu \mathrm{L}$ of LSM solution followed by sintering at $800{ }^{0} \mathrm{C}$ for 1 hour Approximate weight of infiltrated LSM on one YSZ $=(468.8 \mathrm{mg}-468.4 \mathrm{mg})$ scaffold 


\subsection{Results and Discussion}

Note: When the same cell has been characterized after aging at $700{ }^{0} \mathrm{C}$, it is shown as ('), (") or ("'). Calculated activation energies and only the resistances measured at $800{ }^{\circ} \mathrm{C}$ are presented in tables so that the resistances at the other temperatures can be calculated.

\section{Step 1:}

Following are the samples prepared using the LSM pastes. In all these cells, pure LSM or $10 \% \mathrm{C}$-LSM or $50 \% \mathrm{C}$-LSM mixtures were painted on both sides of the bare YSZ electrolyte surface and sintered at $1200{ }^{\circ} \mathrm{C}$.

\section{i. $\mathrm{LSM} / \mathrm{YSZ}$}

ii. $\quad 10 \% \mathrm{C}-\mathrm{LSM} / \mathrm{YSZ}$

iii. $\quad 50 \% \mathrm{C}$-LSM/YSZ

When the series resistances $\left(\mathrm{R}_{\mathrm{s}}\right)$ measured at $800{ }^{0} \mathrm{C}$ are considered (Table 3.1), it can be seen that the Samples $\mathrm{i}$ and ii have the typical series resistance of $\sim 0.7 \mathrm{Ohm} \mathrm{cm}^{2}$ which is assigned to the solid YSZ electrolyte. However, Sample iii shows a higher series resistance which suggests that the LSM was not sintered well to the YSZ electrolyte when 50\% graphite powder was used. This result also supports our observation of LSM electrode delamination in Sample iii.

Polarization resistances $\left(\mathrm{R}_{\mathrm{p}}\right)$ of Samples $\mathrm{i}$ and iii are in the same range $\left(\sim 10 \mathrm{Ohmcm}{ }^{2}\right)$. However, $R_{p}$ values for Sample ii are much lower than for the other samples. When the electrode with LSM/graphite paste sinters at a high temperature, graphite particles burn off and leave pores inside the LSM cathode. These pores facilitate gas transfer inside the LSM cathode and may increase the number of TPBs, which reduces the polarization resistances. 
This might be the reason for lower $R_{p}$ values measured in Sample ii. However, this cannot be observed in sample iii since the electrode did not make a good connection with the electrolyte due to poor sintering.

Table 3.1: Series resistances, polarization resistances and activation energies for LSM/YSZ symmetrical cells.

\begin{tabular}{|c|c|c|c|c|c|}
\hline Sample & Description & $\begin{array}{c}R_{\mathrm{s}} \\
\left(\mathrm{Ohmcm}^{2}\right) \\
\text { at } 800^{0} \mathrm{C}\end{array}$ & $\begin{array}{l}E_{a}(e V) \\
\text { for } R_{s}\end{array}$ & $\begin{array}{c}\mathbf{R}_{\mathrm{p}} \\
\left(\mathrm{Ohmcm}^{2}\right) \\
\text { at } 800^{\circ} \mathrm{C}\end{array}$ & $\begin{array}{l}E_{a}(e V) \\
\text { for } R_{p}\end{array}$ \\
\hline i (a) & $\mathrm{LSM} / \mathrm{YSZ}$ sintered at $1200{ }^{\circ} \mathrm{C}$ & 0.71 & $\begin{array}{c}0.7 \\
(+/-0.0)\end{array}$ & 8.90 & $\begin{array}{c}1.3 \\
(+/-0.1)\end{array}$ \\
\hline i (a)' & $\begin{array}{l}\text { LSM/ YSZ sintered at } 1200{ }^{\circ} \mathrm{C} \text {, } \\
\text { aged } \sim 24 \mathrm{hrs}\end{array}$ & 0.71 & $\begin{array}{c}0.7 \\
(+/-0.0)\end{array}$ & 10.71 & $\begin{array}{c}1.3 \\
(+/-0.1) \\
\end{array}$ \\
\hline ii (a) & $\begin{array}{l}10 \% \mathrm{C}-\mathrm{LSM} / \mathrm{YSZ} \text { sintered at } \\
1200^{\circ} \mathrm{C}\end{array}$ & 0.67 & $\begin{array}{c}0.7 \\
(+/-0.0) \\
\end{array}$ & 5.42 & $\begin{array}{c}1.4 \\
(+/-0.1) \\
\end{array}$ \\
\hline ii (a)' & $\begin{array}{l}10 \% \mathrm{C}-\mathrm{LSM} / \mathrm{YSZ} \text { sintered at } \\
1200^{\circ} \mathrm{C} \text {, aged } \sim 24 \mathrm{hrs}\end{array}$ & 0.67 & $\begin{array}{c}0.7 \\
(+/-0.0) \\
\end{array}$ & 4.11 & $\begin{array}{c}1.5 \\
(+/-0.1) \\
\end{array}$ \\
\hline iii (a) & $\begin{array}{l}50 \% \mathrm{C}-\mathrm{LSM} / \mathrm{YSZ} \text { sintered at } \\
1200{ }^{\circ} \mathrm{C}\end{array}$ & 1.51 & $\begin{array}{c}0.7 \\
(+/-0.0)\end{array}$ & 14.01 & $\begin{array}{c}1.4 \\
(+/-0.1)\end{array}$ \\
\hline iii(a)' & $\begin{array}{l}50 \% \mathrm{C} \text {-LSM / YSZ sintered at } \\
1200{ }^{\circ} \mathrm{C} \text {, aged } \sim 24 \mathrm{hrs}\end{array}$ & 1.52 & $\begin{array}{c}0.7 \\
(+/-0.0)\end{array}$ & 10.01 & $\begin{array}{c}1.7 \\
(+/-0.2)\end{array}$ \\
\hline
\end{tabular}

Jogensen and Mogensen [7] have reported a $\mathrm{R}_{\mathrm{p}}$ value of $\sim 1.6 \mathrm{Ohmcm}^{2}$ (at $1000{ }^{\circ} \mathrm{C}$ ) for an LSM $\left(\left(\mathrm{La}_{0.85} \mathrm{Sr}_{0.15}\right)_{0.9} \mathrm{MnO}_{3 \pm \delta}\right)$ pointed electrode in contact with YSZ (contact area between the LSM electrode and YSZ electrolyte $\sim 10^{-5} \mathrm{~cm}^{2}$ ). Also, Murray and Barnett [8] have reported a $\mathrm{R}_{\mathrm{p}}$ value of $3.5 \mathrm{Ohmcm}^{2}$ at $750{ }^{\circ} \mathrm{C}$ and an activation energy of $1.6 \mathrm{eV}$ for the $\operatorname{LSM}\left(\mathrm{La}_{0.8} \mathrm{Sr}_{0.2} \mathrm{MnO}_{3}\right.$ ) electrode (corresponding to $1.5 \mathrm{Ohmcm}^{2}$ at $800{ }^{\circ} \mathrm{C}$ ) in an $\mathrm{LSM} / \mathrm{YSZ}$ symmetrical cell. Furthermore, Jiang's [2] review paper reports that $\mathrm{R}_{\mathrm{p}}$ values for LSM electrodes at $700{ }^{0} \mathrm{C}$ range from $9-54 \mathrm{Ohmcm}^{2}$. The $\mathrm{R}_{\mathrm{p}}$ values we observed for LSM electrodes in this study are somewhat higher and the activation energies are somewhat lower than these values reported in literature. However, the composition of the LSM paste, the sintering temperature and the A-site deficiency of LSM plays a major role in reducing the polarization resistance of LSM cathodes. 


\section{Step 2:}

Below are the YSZ nanofiber and powder scaffold samples with different LSM current collectors. In all these cells, a thick layer of YSZ nanofiber mixture (thickness of the tape which was used to define the electrode area) was painted on both sides of the YSZ electrolyte and sintered at $1300{ }^{\circ} \mathrm{C}$ or $1400{ }^{\circ} \mathrm{C}$. Then, pure LSM or $10 \% \mathrm{C}$-LSM or $50 \% \mathrm{C}$ LSM mixtures were painted on these YSZ electrodes and sintered at $1200{ }^{\circ} \mathrm{C}$.

iv. LSM/YSZ nanofiber ( 1 tape thick)/YSZ

v. $10 \% \mathrm{C}-\mathrm{LSM} / \mathrm{YSZ}$ nanofiber ( 1 tape thick)/YSZ

vi. $\quad 10 \% \mathrm{C}-\mathrm{LSM} / \mathrm{YSZ}$ nanofiber1400 (1 tape thick)/YSZ

vii. $\quad 50 \% \mathrm{C}$-LSM/YSZ nanofiber (1 tape thick)/YSZ

viii. $\quad 10 \% \mathrm{C}$-LSM/YSZ powder ( 1 tape thick)/YSZ

ix. $\quad 10 \% \mathrm{C}$-LSM/YSZ powder1400 (1 tape thick)/YSZ

Note: LSM/YSZ powder/YSZ and 50\% C-LSM/YSZ powder/YSZ symmetrical cells were prepared but the results are not presented since they had delamination issues.

The series resistances with the YSZ scaffolds are greater than in the absence of the scaffolds (Table 3.2), as expected. When the series resistances of YSZ scaffolds are compared, it can be seen that both the YSZ nanofiber and powder scaffolds which were sintered at $1400{ }^{\circ} \mathrm{C}$ showed lower resistances. Higher sintering temperature assures good connectivity between the porous YSZ scaffold and the YSZ electrolyte, which lowers the resistances. Also, these YSZ scaffolds sintered at $1400{ }^{\circ} \mathrm{C}$ showed better stability with aging. The SEM images (section 2.10.1) show that at $1400{ }^{0} \mathrm{C}$, YSZ nanofibers melt to form a less porous, dense structure. This thinner YSZ structure accounts for the lower series resistance of the YSZ nanofibers fired at the higher temperature. Activation energies of the series resistances are slightly larger than for the solid YSZ electrolyte.

Polarization resistances for these structures are significantly smaller than for LSM paste structures in direct contact with the solid YSZ electrolyte. The rougher YSZ scaffold probably provides more TPB contact length per unit area, thus lowering the polarization resistance. Activation energies are consistent with the values for the LSM/YSZ electrodes 
Pure LSM and 10\% C-LSM were chosen to use as the current collectors for Step 3 since they are more mechanically stable than the 50\% C-LSM current collector.

Table 3.2: Series resistances, polarization resistances and activation energies for LSM/YSZ scaffold/YSZ symmetrical cells.

\begin{tabular}{|c|c|c|c|c|c|}
\hline Sample & Description & $\begin{array}{c}\mathbf{R}_{\mathrm{s}} \\
\left(\mathrm{Ohmcm}^{2}\right) \\
\text { at } 800{ }^{0} \mathrm{C}\end{array}$ & $\begin{array}{l}E_{a}(e V) \\
\text { for } R_{s}\end{array}$ & $\begin{array}{c}\mathrm{R}_{\mathrm{p}} \\
\left(\mathrm{Ohmcm}^{2}\right) \\
\text { at } 800^{0} \mathrm{C}\end{array}$ & $\begin{array}{l}E_{a}(e V) \\
\text { for } R_{p}\end{array}$ \\
\hline i (a) & $\begin{array}{l}\text { LSM/YSZ nanofiber (1 tape thick) } \\
\text { /YSZ }\end{array}$ & 2.53 & $\begin{array}{c}1.0 \\
(+/-0.0)\end{array}$ & 1.95 & $\begin{array}{c}1.3 \\
(+/-0.0)\end{array}$ \\
\hline i (a)' & $\begin{array}{l}\text { LSM/YSZ nanofiber (1 tape thick) } \\
\text { /YSZ, aged } \sim 24 \mathrm{hrs}\end{array}$ & 2.92 & $\begin{array}{c}1.0 \\
(+/-0.0)\end{array}$ & 3.23 & $\begin{array}{c}1.3 \\
(+/-0.0) \\
\end{array}$ \\
\hline ii (a) & $\begin{array}{l}10 \% \mathrm{C}-\mathrm{LSM} / \mathrm{YSZ} \text { nanofiber } \\
(1 \text { tape thick }) / \mathrm{YSZ}\end{array}$ & 3.04 & $\begin{array}{c}0.9 \\
(+/-0.0)\end{array}$ & 2.68 & $\begin{array}{c}1.4 \\
(+/-0.0)\end{array}$ \\
\hline ii (a)' & $\begin{array}{l}10 \% \mathrm{C}-\mathrm{LSM} / \mathrm{YSZ} \text { nanofiber (1 tape } \\
\text { thick)/YSZ, aged } \sim 24 \mathrm{hrs}\end{array}$ & 3.05 & $\begin{array}{c}0.9 \\
(+/-0.0)\end{array}$ & 3.00 & $\begin{array}{c}1.3 \\
(+/-0.0)\end{array}$ \\
\hline iii (a) & $\begin{array}{l}10 \% \mathrm{C}-\mathrm{LSM} / \mathrm{YSZ} \text { nanofiber1400 (1 } \\
\text { tape thick)/YSZ }\end{array}$ & 1.17 & $\begin{array}{c}0.7 \\
(+/-0.0) \\
\end{array}$ & 1.97 & $\begin{array}{c}1.5 \\
(+/-0.0) \\
\end{array}$ \\
\hline iii(a)' & $\begin{array}{l}10 \% \mathrm{C}-\mathrm{LSM} / \mathrm{YSZ} \text { nanofiber1400 (1 } \\
\text { tape thick)/YSZ, aged } \sim 24 \mathrm{hrs}\end{array}$ & 1.18 & $\begin{array}{c}0.7 \\
(+/-0.0) \\
\end{array}$ & 1.76 & $\begin{array}{c}1.2 \\
(+/-0.0) \\
\end{array}$ \\
\hline iv (a) & $\begin{array}{l}50 \% \mathrm{C}-\mathrm{LSM} / \mathrm{YSZ} \text { nanofiber (1 tape } \\
\text { thick)/YSZ }\end{array}$ & 2.05 & $\begin{array}{c}1.0 \\
(+/-0.0) \\
\end{array}$ & 2.06 & $\begin{array}{c}1.4 \\
(+/-0.0) \\
\end{array}$ \\
\hline iv (a)' & $\begin{array}{l}50 \% \mathrm{C}-\mathrm{LSM} / \mathrm{YSZ} \text { nanofiber (1 tape } \\
\text { thick)/YSZ, aged } \sim 24 \mathrm{hrs}\end{array}$ & 2.06 & $\begin{array}{c}1.0 \\
(+/-0.0)\end{array}$ & 2.56 & $\begin{array}{c}1.5 \\
(+/-0.1)\end{array}$ \\
\hline $\mathrm{v}(\mathrm{a})$ & $\begin{array}{l}10 \% \mathrm{C}-\mathrm{LSM} / \mathrm{YSZ} \text { powder (1 tape } \\
\text { thick)/YSZ }\end{array}$ & 4.28 & $\begin{array}{c}0.8 \\
(+/-0.0) \\
\end{array}$ & 4.00 & $\begin{array}{c}1.3 \\
(+/-0.1) \\
\end{array}$ \\
\hline $\mathrm{v}(\mathrm{a})^{\prime}$ & $\begin{array}{l}10 \% \text { C-LSM/YSZ powder (1 tape } \\
\text { thick)/YSZ, aged } \sim 24 \mathrm{hrs}\end{array}$ & 4.08 & $\begin{array}{c}0.8 \\
(+/-0.0) \\
\end{array}$ & 4.50 & $\begin{array}{c}1.2 \\
(+/-0.0) \\
\end{array}$ \\
\hline vi (a) & $\begin{array}{l}10 \% \mathrm{C}-\mathrm{LSM} / \mathrm{YSZ} \text { powder } 1400(1 \\
\text { tape thick)/YSZ }\end{array}$ & 1.61 & $\begin{array}{c}0.8 \\
(+/-0.0) \\
\end{array}$ & 3.07 & $\begin{array}{c}1.4 \\
(+/-0.0) \\
\end{array}$ \\
\hline vi (a)' & $\begin{array}{l}10 \% \text { C-LSM/YSZ powder1400 } \\
\text { tape thick)/YSZ, aged } \sim 24 \mathrm{hrs}\end{array}$ & 1.68 & $\begin{array}{c}0.7 \\
(+/-0.0)\end{array}$ & 3.11 & $\begin{array}{c}1.2 \\
(+/-0.0)\end{array}$ \\
\hline
\end{tabular}

\section{Step 3:}

Below are the LSM infiltrated YSZ nanofiber samples with 10\% C-LSM current collectors. A thick layer of ball milled/ not ball milled YSZ nanofiber mixture (thickness of the tape which was used to define the electrode area) was painted on both sides of the YSZ electrolyte and sintered at $1300{ }^{0} \mathrm{C}$ or $1400{ }^{\circ} \mathrm{C}$. Then, $10 \% \mathrm{C}$-LSM paste was painted on these YSZ electrodes and sintered at $1200{ }^{\circ} \mathrm{C}$. Then, the YSZ scaffolds were infiltrated (through the LSM current collector) with the organic LSM solution (multiple infiltration steps were carried out to achieve $30 \%$ by weight LSM) and sintered at $800{ }^{\circ} \mathrm{C}$ for 1 hour. 
i. $\quad 10 \% \mathrm{C}-\mathrm{LSM} / 30 \% \mathrm{LSM}$ infiltrated YSZ nanofiber/YSZ

ii. $\quad 10 \% \mathrm{C}-\mathrm{LSM} / 30 \% \mathrm{LSM}$ infiltrated YSZ nanofiber1400/YSZ

iii. $\quad 10 \%$ C-LSM/30\% LSM infiltrated ball-milled YSZ nanofiber/YSZ

Table 3.3: Series resistances, polarization resistances and activation energies for LSM infiltrated YSZ nanofiber symmetrical cells with 10\% C-LSM current collector.

\begin{tabular}{|c|c|c|c|c|c|}
\hline Sample & Description & $\begin{array}{c}\mathbf{R}_{\mathrm{s}} \\
\left(\mathrm{Ohmcm}^{2}\right) \\
\text { at } 800^{0} \mathrm{C}\end{array}$ & $\begin{array}{l}E_{a}(e V) \\
\text { for } R_{s}\end{array}$ & $\begin{array}{c}\mathbf{R}_{\mathrm{p}} \\
\left(\mathrm{Ohmcm}^{2}\right) \\
\text { at } 800^{\circ} \mathrm{C}\end{array}$ & $\begin{array}{l}E_{a}(e V) \\
\text { for } R_{p}\end{array}$ \\
\hline i (a) & $\begin{array}{l}10 \% \text { C-LSM } / 30 \% \text { LSM infiltrated } \\
\text { YSZ nanofiber/YSZ }\end{array}$ & 0.72 & $\begin{array}{c}0.6 \\
(+/-0.0)\end{array}$ & 0.21 & $\begin{array}{c}1.5 \\
(+/-0.0)\end{array}$ \\
\hline i (a)' & $\begin{array}{l}10 \% \text { C-LSM } / 30 \% \text { LSM infiltrated } \\
\text { YSZ nanofiber /YSZ, aged } \sim 24 \\
\text { hrs }\end{array}$ & 0.73 & $\begin{array}{c}0.6 \\
(+/-0.0)\end{array}$ & 0.23 & $\begin{array}{c}1.5 \\
(+/-0.1)\end{array}$ \\
\hline i (b) & $\begin{array}{l}10 \% \text { C-LSM } / 30 \% \text { LSM infiltrated } \\
\text { YSZ nanofiber /YSZ }\end{array}$ & 0.78 & $\begin{array}{c}0.7 \\
(+/-0.0)\end{array}$ & 0.20 & $\begin{array}{c}1.5 \\
(+/-0.0)\end{array}$ \\
\hline i (b)' & $\begin{array}{l}10 \% \text { C-LSM } / 30 \% \text { LSM infiltrated } \\
\text { YSZ nanofiber/YSZ, aged } \sim 24 \\
\text { hrs }\end{array}$ & 0.84 & $\begin{array}{c}0.7 \\
(+/-0.0)\end{array}$ & 0.21 & $\begin{array}{c}1.5 \\
(+/-0.1)\end{array}$ \\
\hline i (c) & $\begin{array}{l}10 \% \text { C-LSM } / 30 \% \text { LSM infiltrated } \\
\text { YSZ nanofiber/YSZ }\end{array}$ & 0.92 & $\begin{array}{c}0.7 \\
(+/-0.0)\end{array}$ & 0.29 & $\begin{array}{c}1.6 \\
(+/-0.1)\end{array}$ \\
\hline i (c)' & $\begin{array}{l}10 \% \text { C-LSM } / 30 \% \text { LSM infiltrated } \\
\text { YSZ nanofiber/YSZ, aged } \sim 24 \\
\text { hrs }\end{array}$ & 0.97 & $\begin{array}{c}0.7 \\
(+/-0.0)\end{array}$ & 0.35 & $\begin{array}{c}1.5 \\
(+/-0.0)\end{array}$ \\
\hline ii (a) & $\begin{array}{l}10 \% \text { C-LSM/30\% LSM infiltrated } \\
\text { YSZ nanofiber } 1400 / Y S Z\end{array}$ & 0.82 & $\begin{array}{c}0.7 \\
(+/-0.0)\end{array}$ & 0.15 & $\begin{array}{c}1.3 \\
(+/-0.0)\end{array}$ \\
\hline ii (a)' & $\begin{array}{l}10 \% \text { C-LSM } / 30 \% \text { LSM infiltrated } \\
\text { YSZ nanofiber1400/YSZ, aged } \\
\sim 24 \mathrm{hrs}\end{array}$ & 0.84 & $\begin{array}{c}0.6 \\
(+/-0.1)\end{array}$ & 0.19 & $\begin{array}{c}1.3 \\
(+/-0.0)\end{array}$ \\
\hline ii (a)" & $\begin{array}{l}10 \% \text { C-LSM } / 30 \% \text { LSM infiltrated } \\
\text { YSZ nanofiber1400/YSZ, aged } \\
\text { for another } 3 \text { days }\end{array}$ & 0.84 & $\begin{array}{c}0.7 \\
(+/-0.1)\end{array}$ & 0.22 & $\begin{array}{c}1.4 \\
(+/-0.0)\end{array}$ \\
\hline iii (a) & $\begin{array}{l}10 \% \text { C-LSM } / 30 \% \text { LSM infiltrated } \\
\text { ball-milled YSZ nanofiber/YSZ }\end{array}$ & 1.25 & $\begin{array}{c}0.7 \\
(+/-0.0)\end{array}$ & 0.23 & $\begin{array}{c}1.5 \\
(+/-0.1)\end{array}$ \\
\hline iii (a)' & $\begin{array}{l}10 \% \text { C-LSM } / 30 \% \text { LSM infiltrated } \\
\text { ball-milled YSZ nanofiber/YSZ, } \\
\text { aged } \sim 24 \mathrm{hrs}\end{array}$ & 1.29 & $\begin{array}{c}0.6 \\
(+/-0.0)\end{array}$ & 0.28 & $\begin{array}{c}1.5 \\
(+/-0.1)\end{array}$ \\
\hline \multicolumn{2}{|c|}{ Average values and standard deviations } & $\begin{array}{c}0.91 \\
(+/-0.19)\end{array}$ & $\begin{array}{c}0.7 \\
(+/-0.0)\end{array}$ & $\begin{array}{c}0.23 \\
(+/-0.05)\end{array}$ & $\begin{array}{c}1.5 \\
(+/-0.1)\end{array}$ \\
\hline
\end{tabular}

In Table 3.3, most of the cells show the typical $\mathrm{R}_{\mathrm{s}}$ value for $\mathrm{YSZ}$ at $800{ }^{\circ} \mathrm{C}$, which is $\sim 0.7$ $0.8 \mathrm{Ohmcm}^{2}$ with some exceptions (Sample i(c) and Sample iii). Consequently, the infiltrated LSM must be contacting the solid YSZ electrolyte over the area of the scaffold and must exhibit a low resistance current path through the YSZ scaffold. 
YSZ nanofibers which were sintered at $1400{ }^{\circ} \mathrm{C}$ show the best performance compared to other compositions with lower $R_{p}$ values and lower activation energy for the oxygen reduction reaction. Also, most of the cells did not show a drastic increase in $R_{p}$ values with aging.

When the symmetrical cells were prepared with the YSZ nanofiber paste that was not ballmilled, wide gaps were seen in the cross section SEM images of the electrode (Figure 3.3). Since we wanted to investigate how this affects the cell performance, the paste was ball milled to prepare an electrode with no gaps (Figure 3.4). The $R_{p}$ values are the same for both cell compositions. However, $\mathrm{R}_{\mathrm{s}}$ values are slightly higher for the ball milled YSZ nanofiber electrode, suggesting that the true active area was smaller than the geometric area.

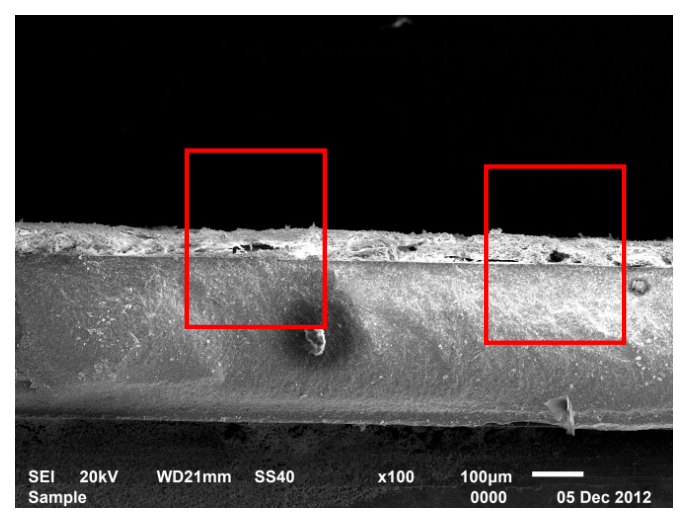

Figure 3.3: Cross section SEM image of YSZ nanofiber electrode prepared using the paste that was not ball-milled. Red squares highlight the gaps.

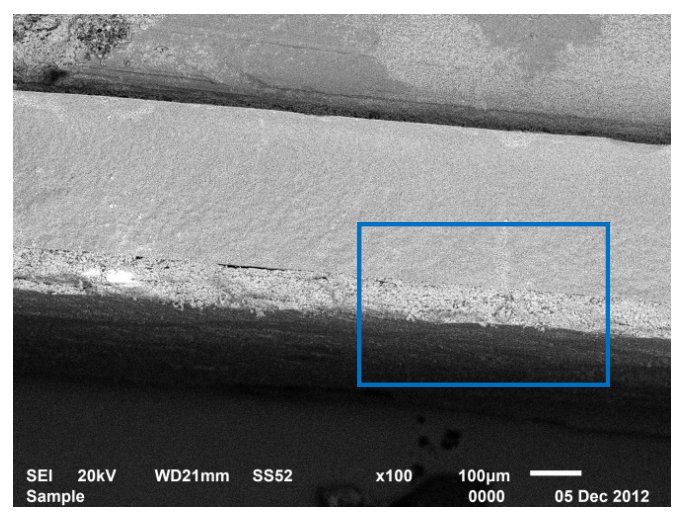

Figure 3.4: Cross section SEM image of YSZ nanofiber electrode prepared using the ball milled paste. Blue square shows the uniform electrode and the electrolyte.

Below are the LSM infiltrated YSZ powder samples with 10\% C-LSM current collectors. A thick layer of YSZ powder paste (thickness of the tape which was used to define the electrode area) was painted on both sides of the YSZ electrolyte and sintered at $1300{ }^{\circ} \mathrm{C}$ or $1500{ }^{\circ} \mathrm{C}$. Then, $10 \%$ C-LSM paste was painted on these YSZ electrodes and sintered at $1200{ }^{\circ} \mathrm{C}$. Then, the YSZ scaffolds were infiltrated (through the LSM current collector) with 
the organic LSM solution (multiple infiltration steps were carried out to achieve $30 \%$ by weight LSM) and the structure sintered at $800{ }^{\circ} \mathrm{C}$ for 1 hour.

$\begin{array}{ll}\text { i. } & 10 \% \mathrm{C}-\mathrm{LSM} / 30 \% \mathrm{LSM} \text { infiltrated YSZ powder/YSZ } \\ \text { ii. } & 10 \% \mathrm{C} \text {-LSM/30\% LSM infiltrated YSZ powder } 1500 / \mathrm{YSZ}\end{array}$

Table 3.4: Series resistances, polarization resistances and activation energies for LSM infiltrated YSZ powder symmetrical cells with 10\% C-LSM current collector.

\begin{tabular}{|c|c|c|c|c|c|}
\hline Sample & Description & $\begin{array}{c}\mathbf{R}_{\mathrm{s}} \\
\left(\mathrm{Ohmcm}^{2}\right) \\
\text { at } \mathbf{8 0 0}^{0} \mathrm{C}\end{array}$ & $\begin{array}{l}E_{a}(e V) \\
\text { for } R_{s}\end{array}$ & $\begin{array}{c}\mathbf{R}_{\mathrm{p}} \\
(\mathrm{Ohmcm}) \\
\text { at } 800^{0} \mathrm{C}\end{array}$ & $\begin{array}{l}E_{a}(e V) \\
\text { for } R_{p}\end{array}$ \\
\hline $\mathrm{i}(\mathrm{a})$ & $\begin{array}{l}10 \% \mathrm{C}-\mathrm{LSM} / 30 \% \mathrm{LSM} \text { infiltrated } \\
\text { YSZ powder/YSZ }\end{array}$ & 0.81 & $\begin{array}{c}0.6 \\
(+/-0.1) \\
\end{array}$ & 0.13 & $\begin{array}{c}1.8 \\
(+/-0.2) \\
\end{array}$ \\
\hline i (a)' & $\begin{array}{l}10 \% \mathrm{C}-\mathrm{LSM} / 30 \% \mathrm{LSM} \text { infiltrated } \\
\text { YSZ powder/YSZ, aged } \sim 24 \mathrm{hrs}\end{array}$ & 0.76 & $\begin{array}{c}0.7 \\
(+/-0.0)\end{array}$ & 0.45 & $\begin{array}{c}1.9 \\
(+/-0.0)\end{array}$ \\
\hline $\mathrm{i}(\mathrm{b})$ & $\begin{array}{l}10 \% \text { C-LSM } / 30 \% \text { LSM infiltrated } \\
\text { YSZ powder/YSZ }\end{array}$ & 0.98 & $\begin{array}{c}0.6 \\
(+/-0.0)\end{array}$ & 0.29 & $\begin{array}{c}1.5 \\
(+/-0.0)\end{array}$ \\
\hline i (b)' & $\begin{array}{l}10 \% \mathrm{C}-\mathrm{LSM} / 30 \% \text { LSM infiltrated } \\
\text { YSZ powder/YSZ, aged } \sim 24 \mathrm{hrs}\end{array}$ & 0.99 & $\begin{array}{c}0.6 \\
(+/-0.0)\end{array}$ & 0.26 & $\begin{array}{c}1.6 \\
(+/-0.1)\end{array}$ \\
\hline i (b)" & $\begin{array}{l}10 \% \text { C-LSM } / 30 \% \text { LSM infiltrated } \\
\text { YSZ powder/YSZ, aged for } \\
\text { another } 3 \text { days }\end{array}$ & 0.99 & $\begin{array}{c}0.7 \\
(+/-0.0)\end{array}$ & 0.29 & $\begin{array}{c}1.5 \\
(+/-0.1)\end{array}$ \\
\hline ii (a) & $\begin{array}{l}10 \% \text { C-LSM } / 30 \% \text { LSM infiltrated } \\
\text { YSZ powder } 1500 / Y S Z\end{array}$ & 1.29 & $\begin{array}{c}0.6 \\
(+/-0.0) \\
\end{array}$ & 0.27 & $\begin{array}{c}1.5 \\
(+/-0.0) \\
\end{array}$ \\
\hline ii (a)' & $\begin{array}{l}10 \% \mathrm{C}-\mathrm{LSM} / 30 \% \mathrm{LSM} \text { infiltrated } \\
\text { YSZ powder } 1500 / \mathrm{YSZ} \text {, aged } \sim 24 \\
\mathrm{hrs}\end{array}$ & 1.21 & $\begin{array}{c}0.6 \\
(+/-0.0)\end{array}$ & 0.34 & $\begin{array}{c}1.5 \\
(+/-0.1)\end{array}$ \\
\hline ii (a)', & $\begin{array}{l}10 \% \text { C-LSM } / 30 \% \text { LSM infiltrated } \\
\text { YSZ powder } 1500 / Y S Z \text {, aged for } \\
\text { another } 3 \text { days }\end{array}$ & 1.18 & $\begin{array}{c}0.7 \\
(+/-0.0)\end{array}$ & 0.35 & $\begin{array}{c}1.5 \\
(+/-0.0)\end{array}$ \\
\hline Aver & ye values and standard deviations & $\begin{array}{c}1.03 \\
(+/-0.19) \\
\end{array}$ & $\begin{array}{c}0.6 \\
(+/-0.0)\end{array}$ & $\begin{array}{c}0.30 \\
(+/-0.09) \\
\end{array}$ & $\begin{array}{c}1.6 \\
(+/-0.2) \\
\end{array}$ \\
\hline
\end{tabular}

All the cells in Table 3.4 (except for Sample i) show higher $\mathrm{R}_{\mathrm{S}}$ values at $800{ }^{0} \mathrm{C}$. The YSZ scaffolds which were sintered at a higher temperature $\left(1500{ }^{0} \mathrm{C}\right)$ show high $\mathrm{R}_{\mathrm{s}}$ values. Possibly the high sintering temperature created a dense non-porous YSZ layer, resulting in a longer ionically conducting path through the cell. The average $R_{p}$ values measured at 800 ${ }^{0} \mathrm{C}\left(0.3 \mathrm{Ohmcm}^{2}\right)$ and the average activation energy $(1.6 \mathrm{eV})$ for the oxygen reduction reaction on these YSZ powder electrodes are slightly higher than the values for YSZ 
nanofiber electrodes $\left(0.23 \mathrm{Ohmcm}^{2}, 1.5 \mathrm{eV}\right.$ respectively) with 10\% C-LSM current collectors. Also, except for Sample i, the cells did not show drastic aging effects.

Below are the LSM infiltrated YSZ nanofiber samples with pure LSM current collectors. A thick layer of (ball milled/ not ball milled) YSZ nanofiber mixture (thickness of the tape which was used to define the electrode area) was painted on both sides of the YSZ electrolyte and sintered at $1300^{\circ} \mathrm{C}$ or $1400^{\circ} \mathrm{C}$. Then, pure LSM paste was painted on these YSZ electrodes and sintered at $1200^{\circ} \mathrm{C}$. Then, the YSZ scaffolds were infiltrated (through the LSM current collector) with the organic LSM solution (multiple infiltration steps were carried out to achieve $30 \%$ by weight LSM) and sintered at $800^{\circ} \mathrm{C}$ for 1 hour.

i. $\quad$ LSM $/ 30 \%$ LSM infiltrated YSZ nanofiber/YSZ

ii. LSM/30\% LSM infiltrated YSZ nanofiber1400/YSZ

iii. $\quad$ LSM/30\% LSM infiltrated ball-milled YSZ nanofiber/YSZ

Table 3.5: Series resistances, polarization resistances and activation energies for LSM infiltrated YSZ nanofiber symmetrical cells with pure LSM current collector.

\begin{tabular}{|c|c|c|c|c|c|}
\hline Sample & Description & $\begin{array}{c}\mathbf{R}_{\mathrm{s}} \\
\left(\mathrm{Ohmcm}^{2}\right) \\
\text { at } 800^{0} \mathrm{C}\end{array}$ & $\begin{array}{l}E_{a}(e V) \\
\text { for } R_{s}\end{array}$ & $\begin{array}{c}\mathbf{R}_{\mathrm{p}} \\
\left(\mathrm{Ohmcm}^{2}\right) \\
\text { at } 800^{0} \mathrm{C}\end{array}$ & $\begin{array}{l}E_{a}(e V) \\
\text { for } R_{p}\end{array}$ \\
\hline i (a) & $\begin{array}{l}\mathrm{LSM} / 30 \% \quad \mathrm{LSM} \text { infiltrated } \mathrm{YSZ} \\
\text { nanofiber/YSZ }\end{array}$ & 1.01 & $\begin{array}{c}0.7 \\
(+/-0.0)\end{array}$ & 0.32 & $\begin{array}{c}1.4 \\
(+/-0.0)\end{array}$ \\
\hline i (a)' & $\begin{array}{l}\mathrm{LSM} / 30 \% \quad \mathrm{LSM} \text { infiltrated } \mathrm{YSZ} \\
\text { nanofiber } / \mathrm{YSZ} \text {, aged } \sim 24 \mathrm{hrs}\end{array}$ & 1.01 & $\begin{array}{c}0.7 \\
(+/-0.0)\end{array}$ & 0.32 & $\begin{array}{c}1.4 \\
(+/-0.0)\end{array}$ \\
\hline i (a)", & $\begin{array}{l}\mathrm{LSM} / 30 \% \text { LSM infiltrated YSZ } \\
\text { nanofiber } / \mathrm{YSZ} \text {, aged for another } 3 \\
\text { days }\end{array}$ & 1.01 & $\begin{array}{c}0.7 \\
(+/-0.0)\end{array}$ & 0.32 & $\begin{array}{c}1.5 \\
(+/-0.0)\end{array}$ \\
\hline $\mathrm{i}(\mathrm{b})$ & $\begin{array}{l}\mathrm{LSM} / 30 \% \quad \mathrm{LSM} \text { infiltrated } \mathrm{YSZ} \\
\text { nanofiber/YSZ }\end{array}$ & 1.22 & $\begin{array}{c}0.6 \\
(+/-0.0) \\
\end{array}$ & 0.36 & $\begin{array}{c}1.4 \\
(+/-0.0) \\
\end{array}$ \\
\hline i (b)' & $\begin{array}{l}\mathrm{LSM} / 30 \% \text { LSM infiltrated YSZ } \\
\text { nanofiber /YSZ, aged for } 3 \text { days }\end{array}$ & 1.18 & $\begin{array}{c}0.7 \\
(+/-0.0)\end{array}$ & 0.39 & $\begin{array}{c}1.5 \\
(+/-0.0)\end{array}$ \\
\hline ii (a) & $\begin{array}{l}\mathrm{LSM} / 30 \% \quad \mathrm{LSM} \text { infiltrated } \mathrm{YSZ} \\
\text { nanofiber1400/YSZ }\end{array}$ & 0.87 & $\begin{array}{c}0.7 \\
(+/-0.0)\end{array}$ & 0.21 & $\begin{array}{c}1.4 \\
(+/-0.0)\end{array}$ \\
\hline ii (a)' & $\begin{array}{l}\mathrm{LSM} / 30 \% \quad \mathrm{LSM} \text { infiltrated YSZ } \\
\text { nanofiber } 1400 / \mathrm{YSZ} \text {, aged } \sim 24 \mathrm{hrs}\end{array}$ & 0.89 & $\begin{array}{c}0.7 \\
(+/-0.0)\end{array}$ & 0.25 & $\begin{array}{c}1.4 \\
(+/-0.0)\end{array}$ \\
\hline ii (a)", & $\begin{array}{l}\text { LSM/30\% LSM infiltrated YSZ } \\
\text { nanofiber 1400/YSZ, aged for } \\
\text { another } \sim 24 \mathrm{hrs}\end{array}$ & 0.90 & $\begin{array}{c}0.7 \\
(+/-0.0)\end{array}$ & 0.25 & $\begin{array}{c}1.5 \\
(+/-0.0)\end{array}$ \\
\hline iii (a) & $\begin{array}{l}\mathrm{LSM} / 30 \% \text { LSM infiltrated ball- } \\
\text { milled YSZ nanofiber/YSZ }\end{array}$ & 1.17 & $\begin{array}{c}0.6 \\
(+/-0.0)\end{array}$ & 0.18 & $\begin{array}{c}1.4 \\
(+/-0.0)\end{array}$ \\
\hline
\end{tabular}




\begin{tabular}{|l|l|c|c|c|c|}
\hline iii (a), & $\begin{array}{l}\text { LSM/30\% LSM infiltrated ball- } \\
\text { milled YSZ nanofiber/YSZ, aged } \\
\sim 24 \mathrm{hr}\end{array}$ & 1.08 & $\begin{array}{c}0.7 \\
(+/-0.0)\end{array}$ & 0.19 & $\begin{array}{c}1.6 \\
(+/-0.0)\end{array}$ \\
\hline iii (a)", & $\begin{array}{l}\text { LSM/30\% LSM infiltrated ball- } \\
\text { milled YSZ nanofiber/YSZ, aged } \\
\text { for another 24 hrs }\end{array}$ & 1.12 & $\begin{array}{c}0.6 \\
(+/-0.0)\end{array}$ & 0.21 & $\begin{array}{c}1.5 \\
(+/-0.0)\end{array}$ \\
\hline iv (a) & $\begin{array}{l}\text { LSM/30\% LSM infiltrated ball- } \\
\text { milled YSZ nanofiber/YSZ }\end{array}$ & 0.95 & $\begin{array}{c}0.7 \\
(+/-0.0)\end{array}$ & 0.18 & $\begin{array}{c}1.7 \\
(+/-0.2)\end{array}$ \\
\hline iv (a)' & $\begin{array}{l}\text { LSM/30\% LSM infiltrated ball- } \\
\text { milled YSZ nanofiber/YSZ, aged } \\
\sim 24 \mathrm{hrs}\end{array}$ & 1.01 & $\begin{array}{c}0.6 \\
(+/-0.1)\end{array}$ & 0.23 & $\begin{array}{c}1.5 \\
(+/-0.0)\end{array}$ \\
\hline iv (a)", & $\begin{array}{l}\text { LSM/30\% LSM infiltrated ball- } \\
\text { milled YSZ nanofiber/YSZ, aged } \\
\text { for another 24 hrs }\end{array}$ & 0.95 & $\begin{array}{c}0.7 \\
(+/-0.1)\end{array}$ & 0.23 & $\begin{array}{c}1.5 \\
(+/-0.1)\end{array}$ \\
\hline Average values and standard deviations & $\begin{array}{c}1.03 \\
(+/-0.11)\end{array}$ & $\begin{array}{c}0.7 \\
(+/-0.0)\end{array}$ & $\begin{array}{c}0.26 \\
(+/-0.07)\end{array}$ & $\begin{array}{c}1.5 \\
(+/-0.1)\end{array}$ \\
\hline
\end{tabular}

In Table 3.5, the series resistances are slightly higher than before, suggesting some discrepancy between the true active area and the electrode geometric area. As we have seen before, YSZ nanofiber electrodes sintered at $1400{ }^{0} \mathrm{C}$ showed the lowest $\mathrm{R}_{\mathrm{s}}$ values at $800{ }^{0} \mathrm{C}$. LSM infiltrated ball-milled YSZ nanofiber electrodes show the lowest $\mathrm{R}_{\mathrm{p}}$ values. Aging studies show that these infiltrated cells are very stable over time. There are no significant differences in polarization resistances with respect to the cell structures with graphite/LSM current collectors.

Below are the LSM infiltrated YSZ powder samples with pure LSM current collectors. A thick layer of YSZ powder (large particles/small particle) paste (thickness of the tape which was used to define the electrode area) was painted on both sides of the YSZ electrolyte and sintered at $1300{ }^{0} \mathrm{C}$ or $1500{ }^{\circ} \mathrm{C}$. Then, LSM paste was painted on these YSZ electrodes and sintered at $1200{ }^{0} \mathrm{C}$. Then, the YSZ scaffolds were infiltrated (through the LSM current collector) with the organic LSM solution (multiple infiltration steps were carried out to achieve $30 \%$ by weight LSM) and sintered at $800{ }^{\circ} \mathrm{C}$ for 1 hour.

i. $\quad \mathrm{LSM} / 30 \% \mathrm{LSM}$ infiltrated YSZ powder/YSZ

ii. LSM/30\% LSM infiltrated YSZ powder1500/YSZ

iii. $\quad \mathrm{LSM} / 30 \% \mathrm{LSM}$ infiltrated $\mathrm{YSZ}$ powder $(\mathrm{SP}) / \mathrm{YSZ}$

The $\mathrm{R}_{\mathrm{s}}$ values for LSM infiltrated YSZ powder electrodes (prepared using smaller particles) are lower than for the other YSZ powder electrodes (Table 3.6). However, the $R_{p}$ 
values are comparatively high for these electrodes. Possibly, these smaller YSZ particles sinter together to form a less porous YSZ scaffold with lower number of TPBs, hence a higher polarization resistance. Also, the average $R_{p}$ value at $800^{0} \mathrm{C}\left(0.45 \mathrm{Ohm} \mathrm{cm}^{2}\right)$ for LSM infiltrated YSZ powder electrodes with LSM current collectors, is as twice as higher than the average $R_{p}$ value for LSM infiltrated YSZ nanofiber electrodes with LSM current collectors $\left(0.26 \mathrm{Ohm} \mathrm{cm}^{2}\right)$. However, the average $\mathrm{R}_{\mathrm{s}}$ values and the activation energies for conductivity across the cell and the oxygen reduction reaction are similar for both LSM infiltrated YSZ scaffolds with LSM current collectors.

Table 3.6: Series resistances, polarization resistances and activation energies for LSM infiltrated YSZ powder symmetrical cells with pure LSM current collector.

\begin{tabular}{|c|c|c|c|c|c|}
\hline Sample & Description & $\begin{array}{c}\mathbf{R}_{\mathrm{s}} \\
\left(\mathrm{Ohmcm}^{2}\right) \\
\text { at } 800^{0} \mathrm{C}\end{array}$ & $\begin{array}{l}E_{a}(e V) \\
\text { for } R_{s}\end{array}$ & $\begin{array}{c}\mathrm{R}_{\mathrm{p}} \\
\left(\mathrm{Ohmcm}^{2}\right) \\
\text { at } \mathrm{800}^{0} \mathrm{C}\end{array}$ & $\begin{array}{l}E_{a}(e V) \\
\text { for } R_{p}\end{array}$ \\
\hline i (a) & $\begin{array}{l}\text { LSM } / 30 \% \text { LSM infiltrated YSZ } \\
\text { powder/YSZ }\end{array}$ & 1.10 & $\begin{array}{c}0.6 \\
(+/-0.0)\end{array}$ & 0.35 & $\begin{array}{c}1.5 \\
(+/-0.1)\end{array}$ \\
\hline i (a)' & $\begin{array}{l}\mathrm{LSM} / 30 \% \text { LSM infiltrated YSZ } \\
\text { powder/YSZ, aged } \sim 24 \mathrm{hrs}\end{array}$ & 1.07 & $\begin{array}{c}0.6 \\
(+/-0.0) \\
\end{array}$ & 0.34 & $\begin{array}{c}1.5 \\
(+/-0.1) \\
\end{array}$ \\
\hline ii (a) & $\begin{array}{l}\text { LSM } / 30 \% \text { LSM infiltrated YSZ } \\
\text { powder } 1500 / Y S Z\end{array}$ & 1.16 & $\begin{array}{c}0.7 \\
(+/-0.0)\end{array}$ & 0.40 & $\begin{array}{c}1.3 \\
(+/-0.1)\end{array}$ \\
\hline ii (a)' & $\begin{array}{l}\text { LSM/30\% LSM infiltrated YSZ } \\
\text { powder } 1500 / Y S Z \text {, aged for } \sim 24 \mathrm{hrs}\end{array}$ & 1.13 & $\begin{array}{c}0.7 \\
(+/-0.0) \\
\end{array}$ & 0.39 & $\begin{array}{c}1.4 \\
(+/-0.1) \\
\end{array}$ \\
\hline ii (a)"' & $\begin{array}{l}\text { LSM } / 30 \% \text { LSM infiltrated YSZ } \\
\text { powder } 1500 / \text { YSZ } \\
\text { another } \sim 24 \mathrm{hrs}\end{array}$ & 1.11 & $\begin{array}{c}0.7 \\
(+/-0.0)\end{array}$ & 0.40 & $\begin{array}{c}1.3 \\
(+/-0.1)\end{array}$ \\
\hline iii (a) & $\begin{array}{l}\text { LSM } / 30 \% \text { LSM infiltrated YSZ } \\
\text { powder }(\mathrm{SP}) / \mathrm{YSZ}\end{array}$ & 0.82 & $\begin{array}{c}0.7 \\
(+/-0.0)\end{array}$ & 0.49 & $\begin{array}{c}1.5 \\
(+/-0.0)\end{array}$ \\
\hline iii (a)' & $\begin{array}{l}\text { LSM } / 30 \% \text { LSM infiltrated YSZ } \\
\text { powder }(\mathrm{SP}) / \mathrm{YSZ}, \text { aged } \sim 24 \mathrm{hrs}\end{array}$ & 0.83 & $\begin{array}{c}0.7 \\
(+/-0.0)\end{array}$ & 0.58 & $\begin{array}{c}1.5 \\
(+/-0.0)\end{array}$ \\
\hline iii (a)" & $\begin{array}{l}\text { LSM } / 30 \% \text { LSM infiltrated YSZ } \\
\text { powder }(\mathrm{SP}) / \mathrm{YSZ} \text {, aged for another } \\
\sim 24 \mathrm{hrs}\end{array}$ & 0.83 & $\begin{array}{c}0.7 \\
(+/-0.0)\end{array}$ & 0.64 & $\begin{array}{c}1.4 \\
(+/-0.0)\end{array}$ \\
\hline \multicolumn{2}{|c|}{ Average values and standard deviations } & $\begin{array}{c}1.01 \\
(+/-0.15)\end{array}$ & $\begin{array}{c}0.7 \\
(+/-0.0)\end{array}$ & $\begin{array}{c}0.45 \\
(+/-0.11)\end{array}$ & $\begin{array}{c}1.4 \\
(+/-0.1)\end{array}$ \\
\hline
\end{tabular}

The best performances (lowest $R_{s}$ and $R_{p}$ values) were obtained using nanofiber YSZ electrodes. However, the $\mathrm{R}_{\mathrm{p}}$ values are not significantly better than the literature values obtained using YSZ powders (see below for discussion). The high cost of YSZ nanofibers 
would prohibit their use in commercial SOFCs. Activation energies are quite consistent, $0.7 \mathrm{eV}$ for YSZ conductivity and $1.4 \mathrm{eV}$ for LSM polarization resistance. In some instances, stable polarization resistances were obtained over short (days) aging periods.

Nevertheless, there are a number of recent reports on ceramic nanofiber cathodes that have shown improved performance. Chang et al. [9] have prepared $\mathrm{Sm}_{0.5} \mathrm{Sr}_{0.5} \mathrm{CoO}_{3-\delta}$ (SSC)/ CGO $\left(\mathrm{Ce}_{0.9} \mathrm{Gd}_{0.1} \mathrm{O}_{1.95}\right)$ symmetrical cells using SSC nanofibers and reports a polarization resistance of $0.01 \mathrm{Ohmcm}^{2}$ at $700{ }^{\circ} \mathrm{C}$, which is lower than the resistance for the powder based SSC/CGO symmetrical cells $\left(0.08 \mathrm{Ohmcm}^{2}\right.$ at $\left.700{ }^{\circ} \mathrm{C}\right)$. Also, Qiang et al. [10] have prepared $\mathrm{La}_{1.6} \mathrm{Sr}_{0.4} \mathrm{NiO}_{4}$ (LSN)/ $\mathrm{CGO}\left(\mathrm{Ce}_{0.9} \mathrm{Gd}_{0.1} \mathrm{O}_{1.95}\right)$ symmetrical cells using LSN nanofibers and have reported a polarization resistance of $0.40 \mathrm{Ohmcm}^{2}$ at $700{ }^{\circ} \mathrm{C}$. Liquan et al. [11] have prepared a $\operatorname{Sr}_{0.7} \mathrm{Y}_{0.3} \mathrm{CoO}_{2.65-\delta}$ (SYCO) nanofiber scaffold which has been infiltrated with $\mathrm{Gd}_{0.2} \mathrm{Ce}_{0.8} \mathrm{O}_{1.9}$ (GDC). They reports a $0.01 \mathrm{Ohmcm}^{2}$ polarization resistance at $750{ }^{\circ} \mathrm{C}$. They have also tested the stability of these SYCO-GDC composite cathodes by a 108 hour constant current test. Furthermore, Liquan et al. [12] have developed a $\mathrm{Sm}_{0.5} \mathrm{Sr}_{0.5} \mathrm{CoO}_{3-\delta^{-}}-\mathrm{Gd}_{0.2} \mathrm{Ce}_{0.8} \mathrm{O}_{1.9}$ (SSC-GDC) composite cathode by infiltrating GDC into a SSC nanofiber cathode. They have reported a $0.038 \mathrm{Ohmcm}^{2}$ polarization resistance at 650 ${ }^{0} \mathrm{C}$ and states that this value is 2.6 times smaller than the polarization resistance of a GDC infiltrated SSC scaffold prepared using nanoparticles. Erqing et al. [13] have prepared $\mathrm{La}_{0.8} \mathrm{Sr}_{0.2} \mathrm{Co}_{0.2} \mathrm{Fe}_{0.8} \mathrm{O}_{3-\delta}$ (LSCF) scaffolds which were infiltrated with $\mathrm{Ce}_{0.8} \mathrm{Gd}_{0.2} \mathrm{O}_{1.9}$ (GDC) and have reported a $0.07 \mathrm{Ohmcm}^{2}$ polarization resistance at $650{ }^{\circ} \mathrm{C}$. Xuening et al. [14] have carried out a comparison study on nanofiber based $\mathrm{GdBaCo}_{2} \mathrm{O}_{5+\delta}$ (GBCO)/ $\mathrm{Ce}_{0.9} \mathrm{Gd}_{0.1} \mathrm{O}_{1.95}$ (GDC) symmetrical cells and powder based GBCO/GDC symmetrical cells. At $750{ }^{\circ} \mathrm{C}$, they have measured a $0.04 \mathrm{Ohmcm}^{2}$ polarization resistance for the nanofiber based cathode and a $0.08 \mathrm{Ohmcm}^{2}$ polarization resistance for the powder based cathode. Also, Li-Ping et al. [15] have prepared $\mathrm{Nd}_{1.93} \mathrm{Sr}_{0.07} \mathrm{CuO}_{4} / \mathrm{CGO}$ symmetrical cells and reports a polarization resistance of $0.26 \mathrm{Ohmcm}^{2}$ at $700{ }^{\circ} \mathrm{C}$. They also state that this value is two times smaller than the resistance obtained for a powder cathode with the same composition.

As we have discussed before, the infiltrated materials can either form discrete particles or a continuous thin film on a cathode backbone. According to Jiang [2], an "ionic conducting" scaffold (eg: YSZ) requires a continuous network of infiltrated particles for good electron 
conduction. The SEM images (Figure 3.5) show the LSM distribution in our YSZ nanofiber and YSZ powder cathodes. The distribution appears to be a continuous network of LSM nanoparticles. Also, Figure 3.6 is the EDS spectrum for the LSM infiltrated YSZ nanofiber cathode which shows the signals for each element present.
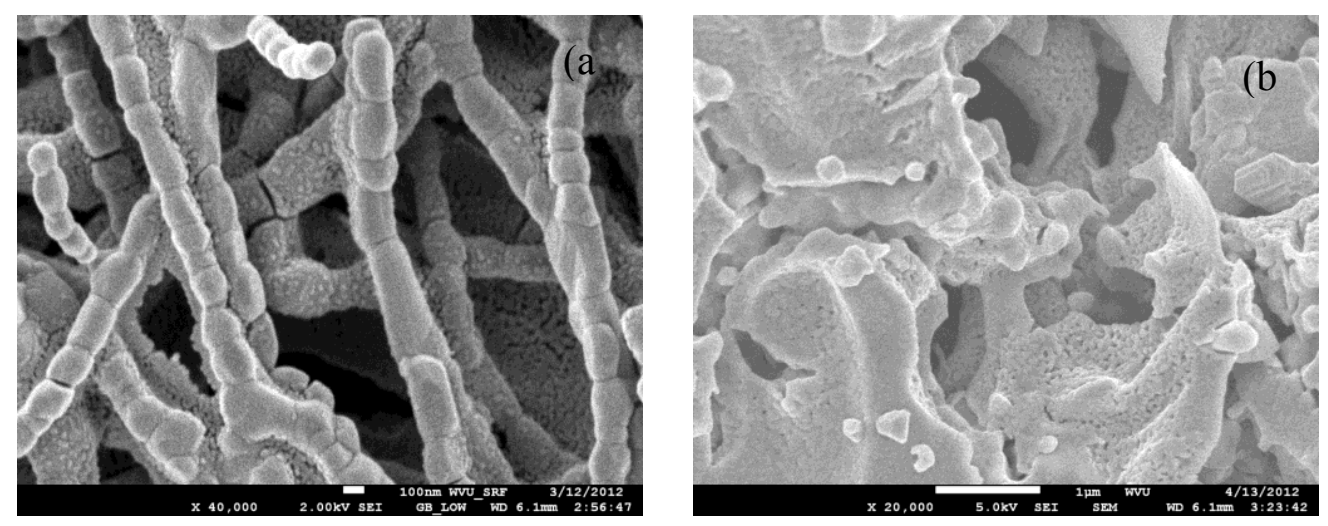

Figure 3.5: SEM images of 30\% LSM infiltrated (a) YSZ nanofiber cathode (b) YSZ powder cathode.

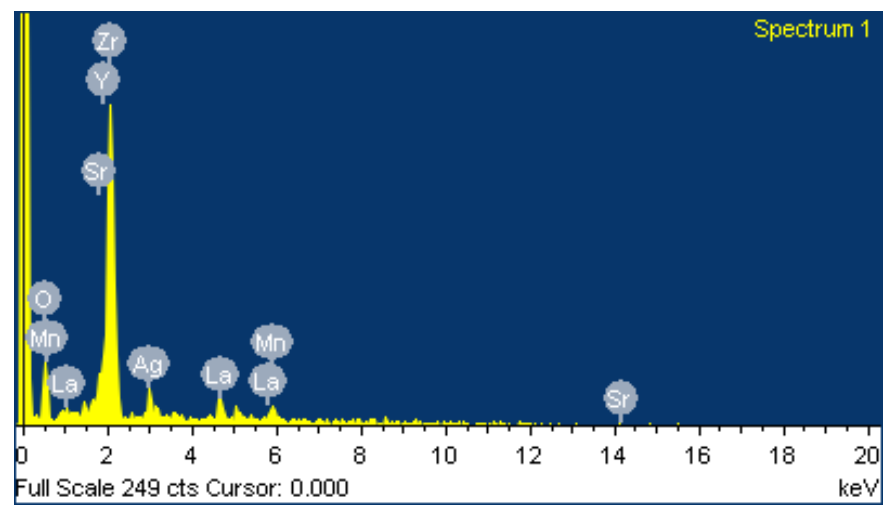

Figure 3.6: EDS spectrum for the LSM infiltrated YSZ nanofiber cathode.

In Chapter 02 - Section II, we have reported the results of a preliminary study on LSM infiltrated YSZ scaffolds, where we used a PAR system to do the electrochemical measurements. However, using proper infiltration techniques and the Solartron system for characterization, we were able to achieve better results for infiltrated YSZ electrodes. Zhi et al.[16] have reported a $\mathrm{R}_{\mathrm{p}}$ value of $0.27 \mathrm{Ohmcm}^{2}$ (at $800{ }^{\circ} \mathrm{C}$ ) for their $50 \% \mathrm{LSM}$ infiltrated 
YSZ nanofiber cathode. We were able to achieve average $R_{p}$ values of $0.23-0.27 \mathrm{Ohmcm}^{2}$ at $800{ }^{\circ} \mathrm{C}$, for $30 \% \mathrm{LSM}$ infiltrated YSZ nanofiber cathodes.

Shah et al. [17] have carried out a similar experiment using symmetrical cells. They sintered YSZ powder scaffolds at $1400{ }^{0} \mathrm{C}$, and again sintered them at $1125{ }^{\circ} \mathrm{C}$ after applying an LSM current collector. Then, these scaffolds were infiltrated with an LSM nitrate solution and sintered at $800{ }^{\circ} \mathrm{C}$. Then, they have recorded EIS data while aging at $800{ }^{\circ} \mathrm{C}$. They report that the $\mathrm{R}_{\mathrm{p}}$ value increased from $0.2 \mathrm{Ohmcm}^{2}$ to $0.5 \mathrm{Ohmcm}^{2}$ after 300 hours. With the LSM infiltrated YSZ nanofibers, we were able to achieve $R_{p}$ values in this range. However, most of the $R_{p}$ values we observed for LSM infiltrated YSZ powder electrodes are higher than this reported value.

Buyukaksoy et al.[6] have characterized LSM infiltrated YSZ powder symmetrical cells using Pt current collectors and they reported an amazing $\mathrm{R}_{\mathrm{p}}$ value of $0.022 \mathrm{Ohmcm}^{2}$ (at 800 ${ }^{0} \mathrm{C}$ ) for their cells and an activation energy of $1.35 \mathrm{eV}$ for the oxygen reduction reaction.

Chen et al. [18] have carried out an experiment to study the effect of sintering temperature on $40 \%$ LSM infiltrated YSZ cathodes. Pt current collectors have been used and they sintered the infiltrated cathodes at $900{ }^{\circ} \mathrm{C}$ and $1100{ }^{\circ} \mathrm{C}$. The symmetrical cell sintered at $900{ }^{0} \mathrm{C}$ exhibited a $R_{p}$ value of $0.21 \mathrm{Ohmcm}^{2}$ at $800{ }^{\circ} \mathrm{C}$ while the other cell showed a $R_{p}$ value of $0.74 \mathrm{Ohmcm}^{2}$. Also, the activation energies for the oxygen reduction reaction on the cells sintered at $900{ }^{\circ} \mathrm{C}$ and $1000{ }^{\circ} \mathrm{C}$ are $1.39 \mathrm{eV}$ and $1.40 \mathrm{eV}$ respectively. The average activation values that we observed for the oxygen reduction reaction ranges from $1.42 \mathrm{eV}$ $1.60 \mathrm{eV}$.

In a study performed by Huang et al.[5], the optimum temperature for sintering an LSM infiltrated YSZ scaffold is reported as $1050{ }^{\circ} \mathrm{C}$. Furthermore, they state that sintering temperatures lower than $1050{ }^{\circ} \mathrm{C}$ form porous LSM while the temperatures higher than $1050{ }^{\circ} \mathrm{C}$ results in dense LSM layers. For a $40 \%$ LSM infiltrated YSZ symmetrical cell sintered at $850{ }^{\circ} \mathrm{C}$, they have achieved a $\mathrm{R}_{\mathrm{p}}$ value of $0.5 \mathrm{Ohmcm}^{2}$ at $700{ }^{\circ} \mathrm{C}$. 


\subsection{Summary}

Even though the porosity is imperative for a better performing cathode current collector, adding $50 \%$ or more graphite to the LSM paste results in delamination. Therefore, pure LSM or LSM with 10\% graphite was used as a current collector. Also, for all the cells that were characterized, a thin Ag paste was applied on top of the LSM to ensure good current collection.

LSM infiltrated YSZ nanofiber scaffolds yielded slightly lower $R_{p}$ values compared to the LSM infiltrated YSZ powder cathodes. However, the decrease in polarization resistance was not dramatic, suggesting that the high surface area of the nanofibers did not result in a large increase in TPB length in the cathode. The high cost of producing YSZ nanofibers would consequently prohibit their use in commercial SOFCs. Both types of cathodes showed similar $E_{a}$ values for oxygen reduction reaction which suggests that the oxygen reduction reaction mechanism on both cathodes is the same.

LSM infiltrated cathodes prepared using YSZ nanofibers sintered at $1400{ }^{\circ} \mathrm{C}$ showed relatively lower $\mathrm{R}_{\mathrm{p}}$ values at $800{ }^{\circ} \mathrm{C}$. The high temperature sintering is known to melt the nanofibers, creating a highly roughened surface structure. Ball-milling the YSZ nanofibers resulted in better electrodes with less gaps but it did not significantly affect the performance of the electrode.

Also, the LSM infiltrated YSZ powder cathodes prepared using smaller particles results in slightly higher $\mathrm{R}_{\mathrm{p}}$ values at $800{ }^{\circ} \mathrm{C}$.

\subsection{Conclusion}

The conventional method to prepare composite cathodes is via mixing ionic conductor and electronic conductor powders together followed by high temperature sintering. Infiltration is a modern technique where the powder based ionic conductor is sintered at a higher temperature to make the scaffold and then it is infiltrated (multiple times) with a precursor solution of electronic conductor before sintering at a lower temperature. For the first time, Zhi et al [9] have prepared a YSZ scaffold using YSZ nanofibers and compared the 
performance of the LSM infiltrated YSZ nanofiber cathode with a composite cathode prepared using LSM and YSZ powders. In this study, we have compared the performance of LSM infiltrated YSZ nanofiber cathodes with LSM infiltrated YSZ powder cathodes. Furthermore, we have carried out the deconvolution analysis on the impedance data collected for these cells and the results are presented in chapter 04 .

Based on our results, both pure LSM and 10\% C-LSM current collectors resulted in similar cell performance which suggests that either current collector can be used without any significant effects. The $\mathrm{R}_{\mathrm{p}}$ values we obtained at $800{ }^{\circ} \mathrm{C}$ are comparable to most of the reported values in literature. However the $\mathrm{E}_{\mathrm{a}}$ value we obtained for the oxygen reduction reaction is slightly higher than the reported values. Also, according to our results, YSZ cathodes prepared using a powder with larger particles results in better performing electrodes. It would be worthwhile to modify the YSZ scaffold in order to achieve a better performing cathode, which will be discussed in Chapter 04 . 


\subsection{References}

1. Ding D., Li X., Lai S.Y., Gerdes K., Liu M., Energy and Environmental Science, 2014, 7, 552-575

2. Jiang S.P., International Journal of Hydrogen Energy, 2012, 37, 449-470.

3. Barthel K., Rambert S., $3^{\text {rd }}$ European Solid Oxide Fuel Cell Forum, 1998, 2, 11-18, ISBN/ISSN: 3-905593-00-2

4. Choi J., Qin W., Liu M., Liu M., Journal of American Ceramic Society, 2011, 94, $3340-3345$

5. Huang Y., Vohs J.M., Gorte R.J., Journal of the Electrochemical Society, 2005, 152, A1347-A1353

6. Buyukaksoy A., Petrovsky V., Dogan F., Journal of the Electrochemical Society, 2012, 159, B68-B72

7. Jorgensen J., Mogensen M., Journal of The Electrochemical Society, 2001, 148, A433-A442

8. Murray E. P., Barnett S.A., Solid State Ionics, 2001, 143, 265-273

9. Chang C-L., Hsu C-S., Huang Jin-Bang., Hsu Pin-Hao., Hwang B-H., Journal of Alloys and Compounds, 2015, 620, 233-239

10. Li Q., Sun L., Zhao Hui., Wang H., Huo L., Rougier A., Fourcade S., Grenier J-C., Journal of Power Sources, 2014, 263, 125-129

11. Fan L., Liu L., Wang Y., Huo H.,Xiong Y., International Journal of Hydrogen Energy, 2014, 39(26), 14428-14433

12. Fan L., Xiong Y., Liu L., Wang Y., Brito M., International Journal of Electrochemical Science, 2013, 8(6), 8603-8613

13. Zhao E., Ma C., Yang W., Xiong Y., Li J., Sun C., International Journal of Hydrogen Energy, 2013, 38 (16), 6821-6829

14. Jiang X., Xu H., Wang Q., Jiang L., Li X., Xu Q., Shi Y., Zhang Q., Journal of Alloys and Compounds, 2013, 557, 184-189

15. Sun L-P., Li Q., Zhao H., Hao J-H., Huo L-H., Pang G., Shi Z., Feng S., International Journal of Hydrogen Energy, 2012, 37(16), 11955-11962 
16. Zhi, M., Mariani,N., Gemmen, R., Gerdes, K.,Wu, N., Energy \& Environmental Science, 2011, 4, 417-420

17. Shah M., Hughes G.A., Voorhees P.W., Barnett S.A., ECS Transactions, 2011, 35, 2045-2053

18. Chen K., Ai N., Jiang S.P, Electrochemistry Communications, 2012, 19, 119-122 


\section{Chapter 04}

\section{Solid Oxide Fuel Cell Cathodes and Deconvolution Studies}

\subsection{Introduction}

The cathode provides the reaction sites for the oxygen reduction reaction (ORR) in a solid oxide fuel cell. Therefore, a cathode must be stable in an oxidizing environment, compatible with other cell components, possess sufficient electronic conductivity and porosity and also needs to have good catalytic activity for oxygen reduction reaction. Lanthanum Strontium Manganite (LSM) is the most widely used SOFC cathode material due to its high electronic conductivity and the compatibility with other cell components including the YSZ electrolyte [1]. LSM by itself can be used as a SOFC cathode while LSM-YSZ composite cathodes prepared by mixing powders or infiltration results in better cell performance.

While operating solid oxide fuel cells at high temperatures, cell performance decreases over time due to degradation of the cell components. Cathode degradation takes place mainly due to changes in the microstructure (e.g., coarsening), cation migration resulting in a poor cathode material, insulating secondary phase formation (e.g., Lanthanum and Strontium Zirconates) and delamination [2], [3]. Therefore, it is important to carry out aging studies in order to investigate the stability of SOFCs over time.

Impedance spectroscopy is a very powerful tool to study SOFCs. Analyzing impedance data is very useful to gain the knowledge needed to design improved microstructures and materials for SOFC cathodes. However, the impedance data collected for SOFCs are very complex since there are overlapping impedance related cell processes taking place. "Deconvolution" (distribution of relaxation times) is a method developed by Ivers-Tiffee [4] in order to identify relaxation times that are relevant to cell processes, using the impedance data. In simple terms, when the impedance data are subjected to deconvolution, the resulting graph shows peaks with different frequencies for different cell processes. This information is very important for proposing a suitable equivalent circuit model, which in turn helps to calculate the polarization resistances at each electrode [3],[4]. A well detailed 
discussion on the deconvolution method is presented in Xiaoke Chen's [3] Ph.D. dissertation. Chapter 1 - Section 1.7 of this dissertation discusses impedance elements and their interpretation in terms of processes.

In this chapter, the experiments carried out with conventional LSM powder cathodes will be discussed in detail first. SOFC researchers around the world have studied composite LSM-YSZ cathodes prepared by infiltrating a pre-sintered porous YSZ backbone with an LSM solution. However, according to our knowledge, no one has studied the catalytic activity of the infiltrating LSM solution alone on the YSZ electrolyte. Therefore, we prepared LSM/YSZ symmetrical cells simply by evaporating the LSM solution on YSZ electrolyte followed by sintering; in order to study the LSM solution-based cathodes using impedance spectroscopy. Finally, the deconvolution studies of impedance data collected for LSM infiltrated YSZ cathodes (described in Chapter 03) and the data for LSM infiltrated YSZ cathodes with improved microstructures will be presented.

\subsection{Powder based LSM cathodes}

Commercial LSM (( $\left.\left.\mathrm{La}_{0.8} \mathrm{Sr}_{0.2}\right)_{0.95} \mathrm{MnO}_{3-\delta}\right)$ powder $(2.4 \mathrm{~g})$ (LSM 20-P, $\mathrm{d}_{50} \sim 1 \mu \mathrm{m}$, Fuel Cell Materials) and the ink vehicle (0.8 g) (3:1 by weight) received from Dr. Edward Sabolsky's (MAE - WVU) laboratory (which contains $\alpha$-terpineol and other additives) were "ballmilled" using a WIG-L-BUG, to produce the paste. The paste was painted on YSZ electrolytes (the thickness was defined by tape) and sintered at a higher temperature to produce LSM powder/YSZ symmetrical cells. The thickness of the LSM electrode after sintering at $1200{ }^{0} \mathrm{C}$ for 1 hour is $\sim 10 \mu \mathrm{m}$.

Initially, a sintering study was carried out to find the optimum sintering temperature for LSM cathodes. Then, the aging studies were carried out on LSM powder/YSZ symmetrical cells.

A Solartron SI 1287 electrochemical interface and 1252A frequency response analyzer were used to perform the electrochemical characterization using Ag current collectors and Ag wires. For comparison, two LSM powder/YSZ symmetrical cells were characterized using $\mathrm{Au}$ and Pt current collectors as well. Impedances were measured using 10 log linear 
frequencies per decade, starting at $100 \mathrm{kHz}$ and ending at $0.1 \mathrm{~Hz}$ or $0.02 \mathrm{~Hz}$. Typically, impedances were collected at $800{ }^{\circ} \mathrm{C}, 750{ }^{\circ} \mathrm{C}$ and $700{ }^{\circ} \mathrm{C}$ to obtain the activation energies of processes.

\subsubsection{Sintering Study of LSM powder cathodes}

\section{Experimental:}

The LSM powder/YSZ symmetrical cells were prepared as mentioned above and sintered at $1050{ }^{0} \mathrm{C}, 1100{ }^{0} \mathrm{C}, 1150{ }^{\circ} \mathrm{C}$ or $1200{ }^{\circ} \mathrm{C}$ for 1 hour. Then, these cells were characterized by impedance spectroscopy.

Table 4.1: Summary of results for the sintering study of LSM powder/YSZ symmetrical cells.

\begin{tabular}{|c|c|c|c|c|}
\hline $\begin{array}{c}\text { Sintering } \\
\text { Temperature } \\
\left.{ }^{0} \mathrm{C}\right)\end{array}$ & $\begin{array}{c}\text { Average } \\
\text { normalized } R_{s} \\
\left(O \mathrm{Omcm}^{2}\right) \text { at } \\
800^{0} \mathrm{C} \\
\end{array}$ & $\begin{array}{c}\text { Average } \\
\text { normalized } R_{p} \\
\left(\mathrm{Ohmcm}^{2}\right) \text { at } \\
800^{0} \mathrm{C} \\
\end{array}$ & $\begin{array}{c}\text { Peak frequency } \\
\text { range }(\mathrm{Hz}) \text { at } \\
800^{\circ} \mathrm{C}\end{array}$ & $E_{a}(e V)$ for $R_{p}$ \\
\hline 1200 & $0.77(+/-0.01)$ & $6.37(+/-0.19)$ & 1 & $1.4(+/-0.1)$ \\
\hline 1150 & $0.78(+/-0.01)$ & $9.65(+/-0.54)$ & $1-4$ & $1.4(+/-0.2)$ \\
\hline 1100 & 0.81 & 14.88 & 6 & 1.4 \\
\hline 1050 & $0.79(+/-0.04)$ & $11.21(+/-2.88)$ & $4-10$ & $1.5(+/-0.0)$ \\
\hline
\end{tabular}

\section{$\underline{\text { Results and Discussion: }}$}

The average series resistances at $800{ }^{0} \mathrm{C}$ range from 0.77 to $0.81 \mathrm{Ohmcm}^{2}$ while the lowest resistance is obtained for the cell sintered at $1200{ }^{0} \mathrm{C}$. This series resistance range is consistent with previous measured series resistances on the commercial YSZ plates. The lowest polarization resistance was also obtained for the cell sintered at $1200{ }^{0} \mathrm{C}$. The activation energy values obtained for the oxygen reduction reaction are in the same range for these LSM cathodes sintered at different temperatures, except for the cells sintered at $1050{ }^{\circ} \mathrm{C}$. Furthermore, these activation energy values are in the same range $(1.5-1.7 \mathrm{eV})$ as reported in literature [3].

As Cronin et al. [5] have reported for LSM-YSZ composite cathodes, the peak frequency of the impedance spectra of these LSM cathodes show a decreasing trend with the increasing sintering temperature. Since the LSM powder/YSZ symmetrical cell sintered 
at $1200{ }^{\circ} \mathrm{C}$ showed the lowest and reproducible resistances which are comparable to previously reported values [3], [6], $1200{ }^{\circ} \mathrm{C}$ was chosen as the sintering temperature for our LSM powder cathodes. The SEM image of the top surface of an LSM powder cathode sintered at $1200{ }^{\circ} \mathrm{C}$ for 1 hour (Figure 4.1) shows a well-connected network of LSM particles with dimensions on the order of 1 micron and also sufficient porosity.

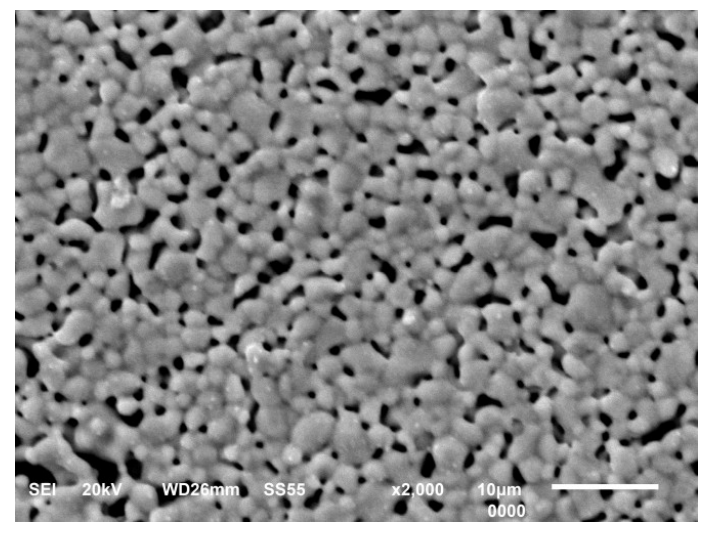

Figure 4.1: SEM image of an LSM cathode sintered at $1200{ }^{\circ} \mathrm{C}$ for 1 hour.

\subsubsection{Aging Study of LSM powder/YSZ symmetrical cells}

\section{Experimental:}

As mentioned in Section 4.2.1, a LSM powder/YSZ symmetrical cell was prepared and characterized as follows:

Day 1: Electrochemical characterization at $800{ }^{\circ} \mathrm{C}, 750{ }^{\circ} \mathrm{C}, 700{ }^{\circ} \mathrm{C}$ and aging overnight at $800{ }^{\circ} \mathrm{C}$

Days $2 \& 4$ : Record an initial reading at $800{ }^{\circ} \mathrm{C}$; change the temperature to $700{ }^{\circ} \mathrm{C}$ and after 1 hour, record readings at each hour and age overnight at $700{ }^{\circ} \mathrm{C}$.

Days 3 \& 5: Record an initial reading at $700{ }^{\circ} \mathrm{C}$; change the temperature to $800{ }^{\circ} \mathrm{C}$ and after 1 hour, record readings at each hour and age overnight at $800{ }^{\circ} \mathrm{C}$. 
Results and Discussion:
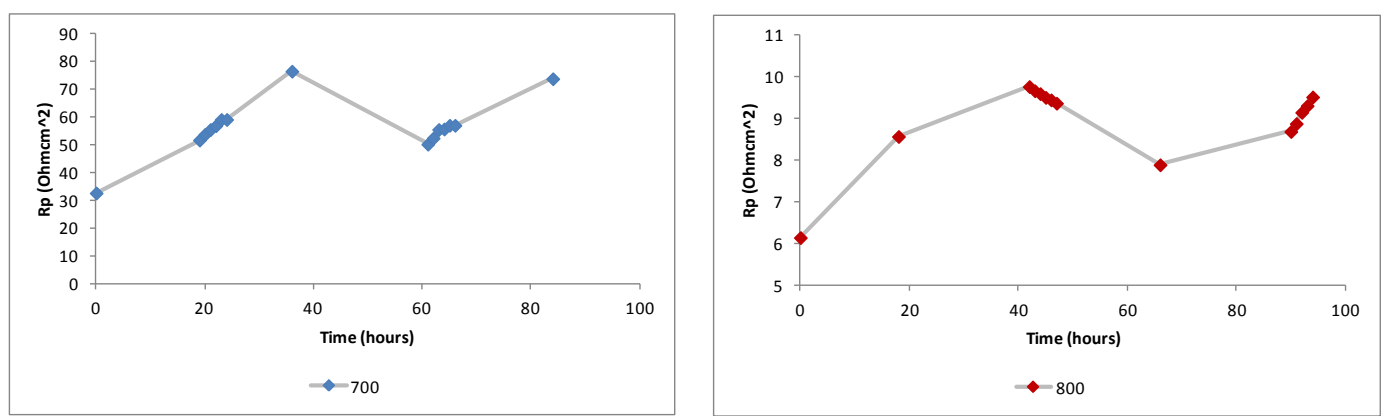

Figure 4.2: Polarization resistances recorded over time during the aging experiment for LSM powder cathode sintered at $1200{ }^{0} \mathrm{C}$ on YSZ. This figure shows the cathode behavior vs. time over the entire experiment.
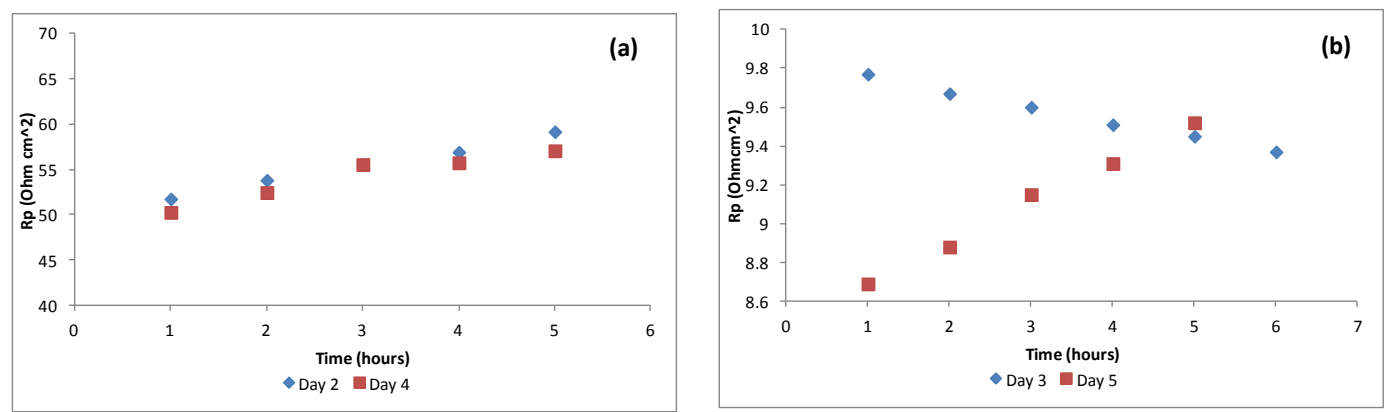

Figure 4.3: Polarization resistances recorded at (a) $700{ }^{\circ} \mathrm{C}$ and (b) $800{ }^{\circ} \mathrm{C}$ for aging of LSM powder cathode sintered at $1200{ }^{0} \mathrm{C}$ on YSZ. This figure shows the cathode behavior vs. time from the temperature change. At the beginning of Day 2 and Day 4, the cell temperature was dropped from $800{ }^{\circ} \mathrm{C}$ to $700{ }^{\circ} \mathrm{C}$. At the beginning of Day 3 and Day 5, the cell temperature was raised from $700{ }^{\circ} \mathrm{C}$ to $800{ }^{\circ} \mathrm{C}$.

When the cell aging over the course of time of complete experiment (Figure 4.2) is considered, polarization resistances and series resistances generally showed an increasing trend at both temperatures. However, after aging at Day 3 cell polarization decreased considerably and increased again at Day 5.

When the polarization resistances were recorded at each hour (Figure 4.3), the resistances at $700{ }^{\circ} \mathrm{C}$ showed a reproducible increasing trend (on both Day 2 and Day 4) while one set of resistances at $800{ }^{\circ} \mathrm{C}$ showed a decreasing trend (Day 3) and the resistances recorded in Day 5 showed an increasing trend. The pattern observed for polarization resistances at 700 
${ }^{0} \mathrm{C}$ is similar to the reversible cathode aging trend reported by Abernathy et al. [6] for LSM/YSZ symmetrical cells when the temperature was cycled between $700{ }^{\circ} \mathrm{C}$ and $800{ }^{\circ} \mathrm{C}$. Unlike our data, they have observed the reproducible decreasing pattern for polarization resistances recorded at $800{ }^{\circ} \mathrm{C}$ as well. However, their experimental approach is different since their symmetrical cells were initially aged at $800{ }^{\circ} \mathrm{C}$ for 500 hours in order to remove the effects of irreversible cell aging, before the cell was thermally cycled [6]. Therefore, the reason for not observing the reversible pattern (at $800{ }^{\circ} \mathrm{C}$ ) in our data may be because our cell was still undergoing the irreversible thermal aging which results in increased polarization resistances.

Abernathy et al. [6] propose the "cation segregation" as a possible cause for the reversible aging behavior they observed at $700{ }^{\circ} \mathrm{C}$ and $800{ }^{\circ} \mathrm{C}$. Cation migration can take place due to the changes in cathode microstructure, redistribution of cations throughout the lattice or secondary phase formation [6]. Jiang and Love [7] have reported that LSM cathodes tend to form passive surface layers such as $\mathrm{SrO}$ and $\mathrm{MnO}_{\mathrm{x}}$ which results in lower cell performance. Also, there are several studies [8], [9] showing that the degree of Sr enrichment (passive $\mathrm{SrO}$ formation) on LSM increase with decreasing temperature, which might be the reason for increasing $\mathrm{R}_{\mathrm{p}}$ values observed at $700{ }^{\circ} \mathrm{C}$. However, Caillol et al. [10] have reported contradictory results where they observed Sr segregation on LSM surface at $1200{ }^{\circ} \mathrm{C}$ and desegregation at $800{ }^{\circ} \mathrm{C}$, which means the cation segregation increase with increasing temperature. The cause of the slow reversible aging remains uncertain.

\subsubsection{Deconvolution studies of LSM powder/YSZ symmetrical cells}

Deconvolution of the impedance data obtained for LSM powder cathodes resulted in a complex spectrum with several overlapping peaks indicating multiple processes. Figure 4.3 (d) shows a negative out of phase impedance vs log frequency plot with individual RQ elements for impedance data of LSM/YSZ symmetrical cell with Au current collectors at $800{ }^{\circ} \mathrm{C}$. Therefore, an equivalent circuit of LR(RQ)3 and the Zview ${ }^{\circledR}$ software were used to fit the impedance data and obtain the polarization resistances (Table 4.2). Notice that the peak frequencies lie around $1.5-5 \mathrm{~Hz}$ for these LSM powder cathodes. 
Figure 4.4 shows the deconvoluted data (blue) and the simulation result obtained using the equivalent circuit fitting (red) for LSM powder/YSZ symmetrical cells with different current collectors. These deconvoluted and simulated spectra show a reasonable agreement except for the discrepancies at lower frequencies especially with the Ag current collector.
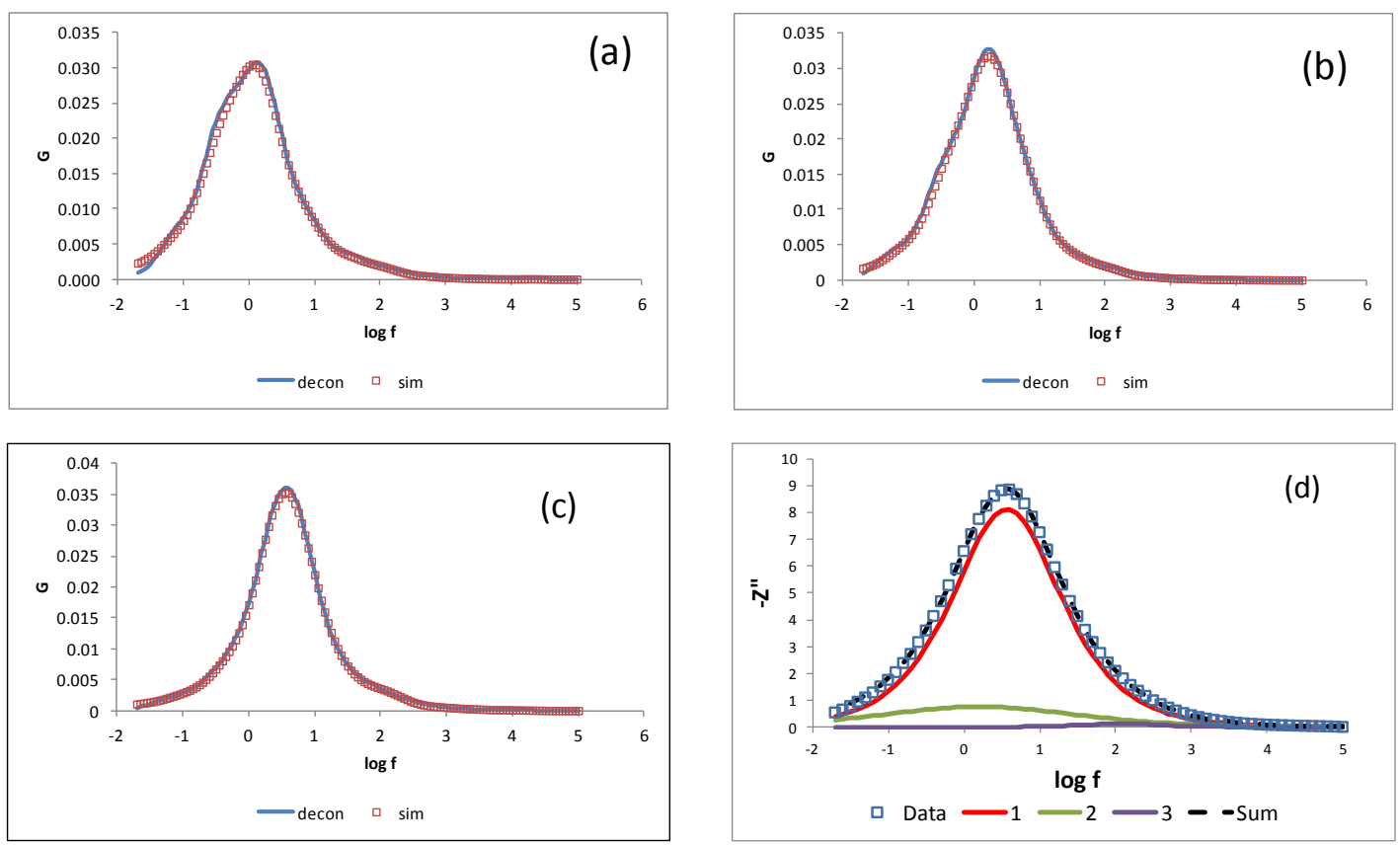

Figure 4.4: Deconvoluted and simulated data for LSM powder/YSZ symmetrical cells at $800{ }^{0} \mathrm{C}$ with (a) Ag (b) Pt and (c) Au current collectors; (d) negative out of phase impedance vs log frequency plot with equivalent circuit fitting (3 RQ elements) of impedance data collected for (c).

Xiaoke Chen [3] has also performed a deconvolution analysis on commercial LSM powder/YSZ symmetrical cells (sintered at $1200{ }^{\circ} \mathrm{C}$ for 4 hours and characterized using $\mathrm{Au}$ current collectors) and used an equivalent circuit consist of 5RQ elements in order to fit the impedance data. The peak frequency of her reported data lies around $63 \mathrm{~Hz}$.

Polarization resistances and the activation energies for the oxygen reduction reaction (presented in Table 4.2), of these LSM powder/YSZ symmetrical cells are comparable to the typical values of LSM powder cathodes that have been reported previously [3]. For silver and platinum current collectors, one RQ element dominates the impedance. As will be shown in chapter 5, typical equivalent circuit values for the LSM paste electrodes are around $\mathrm{R}=10 \mathrm{Ohmcm}^{2}, \mathrm{Q}=0.01, \mathrm{n}=0.7$, and the peak frequency is near $1 \mathrm{~Hz}$. 
Table 4.2: Normalized fitting parameters for at $800{ }^{\circ} \mathrm{C}$ with (a) $\mathrm{Ag}$ (b) $\mathrm{Pt}$ and (c) $\mathrm{Au}$ current collectors for LSM powder/YSZ symmetrical cells.

\begin{tabular}{|c|c|c|c|c|c|}
\hline & & $\begin{array}{c}\text { Ag Current } \\
\text { Collector }\end{array}$ & $\begin{array}{c}\text { Pt Current } \\
\text { Collector }\end{array}$ & $\begin{array}{c}\text { Au Current } \\
\text { Collector }\end{array}$ & \\
\hline Element & Parameter & Value & Value & Value & Units \\
\hline Series R & R1 & 0.61 & 0.86 & 0.86 & Ohmcm $^{2}$ \\
\hline Inductance & L & $2.74 \mathrm{E}-07$ & $2.86 \mathrm{E}-07$ & $3.14 \mathrm{E}-07$ & $\mathrm{Hcm}^{2}$ \\
\hline RQ1 & R2 & $8.9 \mathrm{E}-03$ & 0.08 & 0.09 & Ohmcm $^{2}$ \\
\hline RQ2 & R3 & 0.14 & 0.81 & 7.17 & Ohmcm $^{2}$ \\
\hline RQ3 & R4 & 12.13 & 14.62 & 1.18 & Ohmcm \\
\hline RQ1 & $\mathrm{n} 1$ & 1 & 1 & 1 & \\
\hline RQ2 & $\mathrm{n} 2$ & 0.879 & 0.921 & 0.765 & \\
\hline RQ3 & $\mathrm{n} 3$ & 0.692 & 0.698 & 0.479 & \\
\hline RQ1 & $\mathrm{f} 1$ & 39000 & 92 & 123 & $\mathrm{~Hz}$ \\
\hline RQ2 & $\mathrm{f} 2$ & 79 & 4 & 4 & $\mathrm{~Hz}$ \\
\hline RQ3 & $\mathrm{f} 3$ & 1 & 1 & 2 & $\mathrm{~Hz}$ \\
\hline RQ1 & $\mathrm{Q} 1$ & $4.57 \mathrm{E}-04$ & $2.29 \mathrm{E}-02$ & $1.46 \mathrm{E}-02$ & \\
\hline RQ2 & $\mathrm{Q} 2$ & $3.03 \mathrm{E}-02$ & $6.53 \mathrm{E}-02$ & $8.51 \mathrm{E}-02$ & \\
\hline RQ3 & $\mathrm{Q} 3$ & $2.36 \mathrm{E}-02$ & $1.52 \mathrm{E}-02$ & $3.83 \mathrm{E}-03$ & \\
\hline $\begin{array}{c}\text { Polarization } \\
\text { R }\end{array}$ & $\mathrm{R}$ & 6.14 & 7.75 & 4.22 & $\mathrm{Ohmcm}{ }^{2}$ \\
\hline $\begin{array}{c}\text { Activation } \\
\text { Energy for } \\
\text { ORR }\end{array}$ & $\mathrm{E}$ & $1.5(+/-0.0)$ & $1.7(+/-0.0)$ & $1.7(+/-0.0)$ & $\mathrm{eV}$ \\
\hline
\end{tabular}

\subsection{Solution based LSM cathodes}

The conventional LSM cathodes are prepared using powders that are pre-sintered to higher temperatures during processing steps. According to Sasaki et al [11], processing parameters including calcination temperature, characteristics including particle size of the LSM powder and the cathode sintering temperature greatly influence the cathode microstructure and hence the cathode performance. Therefore, we have tried to prepare and characterize LSM solution based cathodes that were not pre-sintered at very high temperatures.

An organic LSM precursor solution (0.1 M) was prepared as mentioned in Section 3.2 [12]. An aqueous LSM precursor solution $(0.03 \mathrm{M})$ was prepared following the procedure 
published by Zhu et al. [13]. In order to prepare the aqueous LSM solution, proper amounts of $\mathrm{La}\left(\mathrm{NO}_{3}\right)_{3} \cdot 6 \mathrm{H}_{2} \mathrm{O}(0.3 \mathrm{~g}), \operatorname{Sr}\left(\mathrm{NO}_{3}\right)_{2}(31.7 \mathrm{mg})$ and $\mathrm{Mn}\left(\mathrm{NO}_{3}\right)_{2}(120 \mu \mathrm{L})$ were dissolved in a mixture of water $(12.5 \mathrm{~mL})$ and ethanol $(12.5 \mathrm{~mL})(1: 1)$ with glycine $(142$ $\mathrm{mg}$ ) (molar ratio LSM : Glycine: $=1: 2.53)$ and polyvinyl pyrrolidone powder $(12.5 \mathrm{mg})$ ( 0.05 weight $\%$ of LSM solution). Concentrated nitric acid was added to adjust the $\mathrm{pH}$ of the solution to $\sim 3$. The wetting properties of these solutions were characterized using contact angle goniometry. Furthermore, the resulting powders were characterized by X-ray diffractometry (XRD) and Thermogravimetric Analysis (TGA).

Then, LSM solution/YSZ symmetrical cells were prepared by evaporating LSM precursor solutions on YSZ and firing at $800{ }^{\circ} \mathrm{C}, 900{ }^{\circ} \mathrm{C}, 1000{ }^{\circ} \mathrm{C}$ or $1200{ }^{\circ} \mathrm{C}$ for 1 hour. Initially, $\mathrm{Ag}$ current collectors were used for electrochemical characterization. However, $\mathrm{Pt}$ and $\mathrm{Au}$ current collectors were also used later for comparison. Aging studies of these cathodes were carried out as well. Furthermore, a symmetrical cell based on LSM solution electrodes was prepared on HIOINIC® electrolyte as well in order to study the effect of the electrolyte. Finally, how the organic solution based LSM cathode (with Ag current collector) behaves with different oxygen partial pressures was studied.

\subsubsection{Contact Angle Measurements}

A telescope goniometer (Dr. Peter Gannett's laboratory, Health Sciences Campus, WVU) (Figure 4.5) was used to measure the contact angle between the LSM solution droplet and the YSZ surface. A contact angle smaller than $90^{\circ}$ means the solution tends to wet the surface well while a contact angle larger than $90^{\circ}$ means the solution has a less tendency to spread over the surface (Figure 4.6) [13].

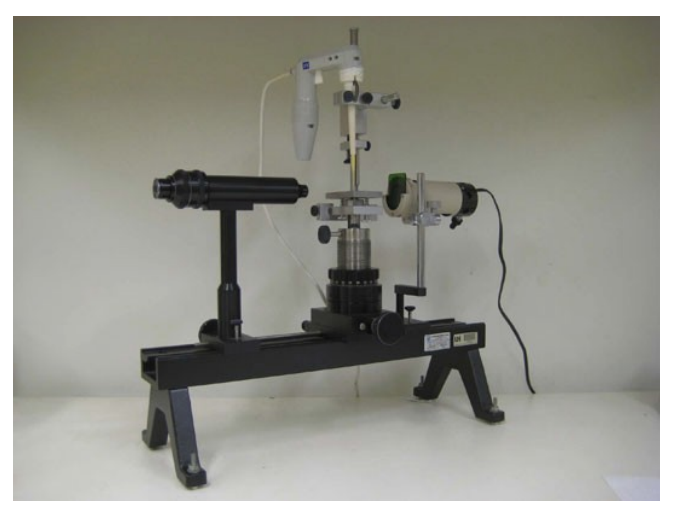

Figure 4.5: A telescope goniometer [14]. 


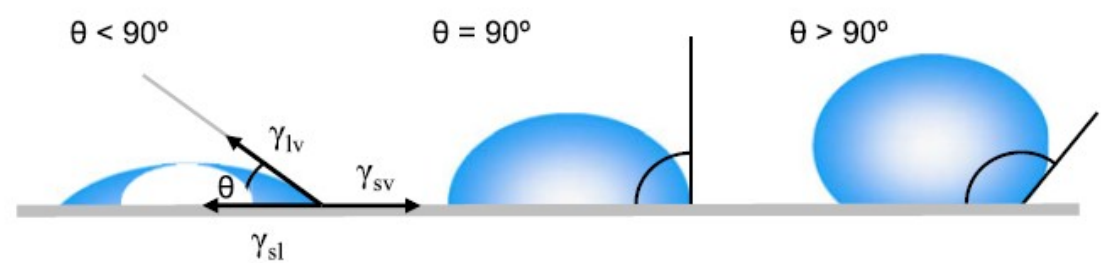

Figure 4.6: Different contact angle measurements [14].

\section{Experimental:}

As received YSZ electrolytes and YSZ electrolytes pre-heated at $500{ }^{\circ} \mathrm{C}$ for $\sim 30$ minutes and cooled to room temperature (to make the surfaces hydrophilic) were used as substrates in order to investigate the wetting properties of organic and aqueous LSM solutions using a telescope goniometer.

\section{Results and Discussion}
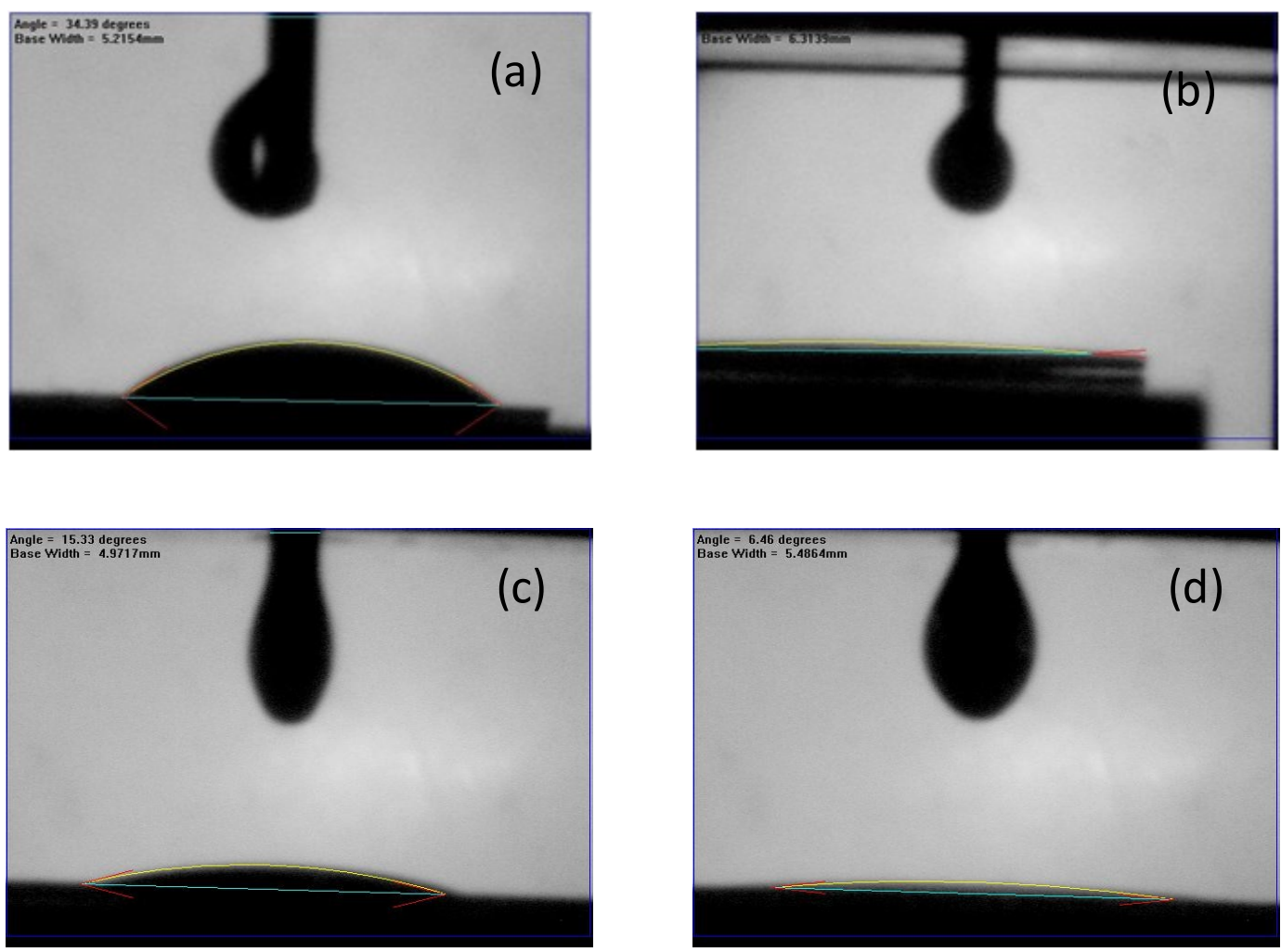

Figure 4.7: Contact angle measurements for aqueous LSM solution on as received YSZ (a) and hydrophilic YSZ (b) and organic LSM solution on as received YSZ (c) and hydrophilic YSZ (d). 
The average contact angle measurement for aqueous LSM solution on as received YSZ is $35.2^{0}$ while it is $4.3^{0}$ on hydrophilic YSZ. Also, the average contact angle measurement for organic LSM solution on as received YSZ is $15.9^{\circ}$ and $6.7^{0}$ on hydrophilic YSZ. This shows that both aqueous and organic LSM solutions readily spread on the hydrophilic YSZ surfaces (Figure 4.7).

\subsubsection{XRD analysis}

In order to ensure that our precursor solutions result in crystalline LSM upon sintering, XRD analysis of the powders were carried out at the NETL-Morgantown site.

\section{Experimental:}

Aqueous and organic LSM precursor solutions were placed in two different crucibles and sintered at $800^{\circ} \mathrm{C}$ for 1 hour. Then, the resulting powders were characterized by XRD.

\section{$\underline{\text { Results and Discussion: }}$}

XRD data shown in figure 4.8 show that LSM phase is formed since the characteristic peaks for LSM in an XRD spectrum can be seen at $2 \theta \sim=23,33,42,47,53,59$ and $69^{\circ}$ [12].
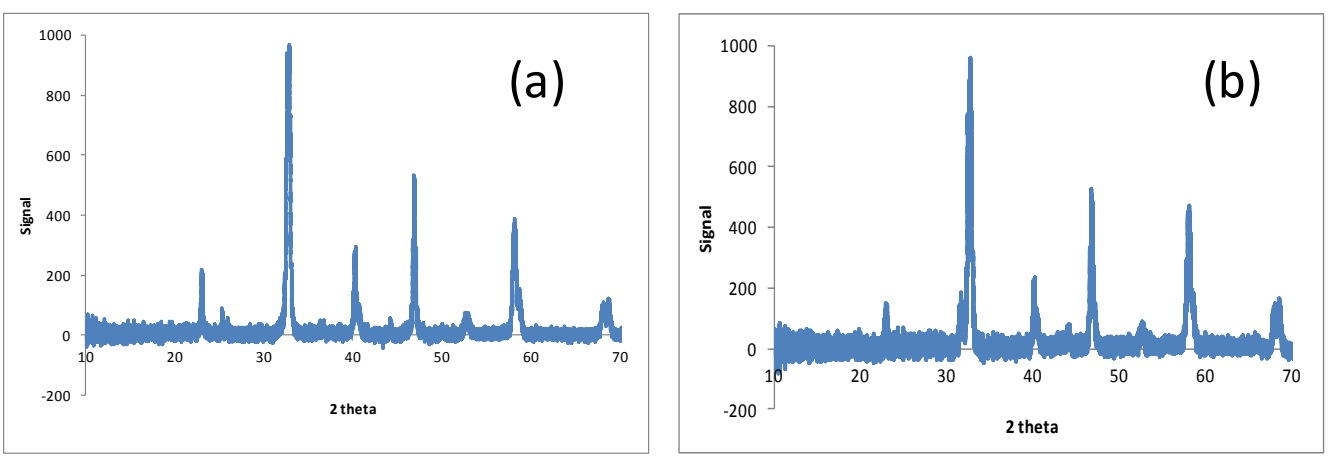

Figure 4.8: XRD data for aqueous LSM (a) and organic LSM (b). 


\subsubsection{Thermogravimetric Analysis}

In thermogravimetric analysis (Dr. Jingxing Wang's laboratory, Division of Forestry and Natural Resources, WVU), the mass of a sample (which is in a controlled atmosphere) is continuously recorded (as a function of time) while the temperature of the sample is linearly increased. TGA can provide information about decomposition reactions, oxidation reactions, vaporization, sublimation and desorption processes of the sample [15].

\section{Experimental:}

Both organic and aqueous LSM precursor solutions were evaporated on YSZ electrolyte pieces while heating to a temperature $\sim 80{ }^{0} \mathrm{C}$ in order to obtain dry samples. Since these samples were highly hygroscopic, they were stored in a desiccator until the analysis was done. TGA of the samples were carried out (in atmospheric conditions without any gas purging) while heating the sample to $900{ }^{0} \mathrm{C}$ using a $20{ }^{0} \mathrm{C} / \mathrm{min}$ ramp rate and held at 900 ${ }^{0} \mathrm{C}$ for another 30 minutes.

\section{$\underline{\text { Results and Discussion: }}$}

Thermograms recorded during the TGA experiment are shown in Figure 4.9. According to previously published data [16]-[18], the initial weight loss from the start to around $150{ }^{0} \mathrm{C}$ $200{ }^{0} \mathrm{C}$ is due to evaporation of water and loss of surface adsorbed gas molecules. The weight change around $200{ }^{0} \mathrm{C}-\sim 400{ }^{0} \mathrm{C}$ is assigned to decomposition of nitrates and organic matter. The final weight changes occur with the oxide formation which results in the LSM phase. No weight change was observed when the TGA was continued for 30 minutes at $900{ }^{0} \mathrm{C}$ which ensures the complete LSM formation had already taken place. Also, there is no significant weight change between $800{ }^{\circ} \mathrm{C}$ and $900{ }^{\circ} \mathrm{C}$ which means the LSM phase is already formed at $800{ }^{\circ} \mathrm{C}$. 


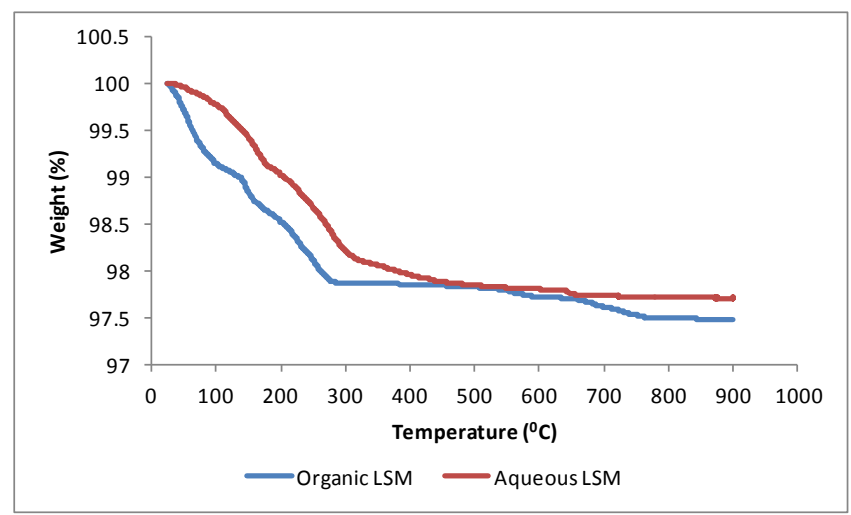

Figure 4.9: Thermograms for organic (blue) and aqueous (red) LSM precursor

\subsubsection{Sintering study of LSM solution based cathodes}

\section{Experimental:}

Organic and aqueous LSM solutions were deposited on both sides of YSZ electrolytes ( $10-20 \mathrm{uL}$ total volume in multiple depositions of $\sim 5 \mathrm{uL}$ aliquots) and dried at $\sim 100{ }^{0} \mathrm{C}$. A dried layer of varnish was used to define the area of the electrodes. Then these LSM solution/YSZ symmetrical cells were sintered at $800{ }^{0} \mathrm{C}, 900{ }^{0} \mathrm{C}, 1000{ }^{0} \mathrm{C}$ or $1200{ }^{0} \mathrm{C}$ for 1 hour. Electrochemical characterizations of the cells were done using $\mathrm{Ag}$ wires and $\mathrm{Ag}$ current collectors.

\section{$\underline{\text { Results and Discussion: }}$}

Note that in samples shown in tables 4.3 and 4.4, only the solution based LSM cathodes were sintered at different temperatures $\left(800{ }^{0} \mathrm{C}, 900{ }^{0} \mathrm{C}, 1000{ }^{0} \mathrm{C}\right.$ or $\left.1200{ }^{\circ} \mathrm{C}\right)$. After that, all the cathodes were characterized in the same way after applying Ag paste as the current collector followed by heating to $800{ }^{0} \mathrm{C}$. Therefore, it would be assumed that the differences in the cathode performance are due to the different sintering temperatures of the LSM phase. 
Table 4.3: Summary of results for the sintering study of organic LSM solution/YSZ symmetrical cells.

\begin{tabular}{|c|c|c|c|c|}
\hline $\begin{array}{c}\text { Sintering } \\
\text { Temperature } \\
\left({ }^{\mathbf{}} \mathbf{C}\right)\end{array}$ & $\begin{array}{c}\text { Average normalized } \\
\mathbf{R}_{\mathbf{s}}\left(\mathbf{O h m} \mathbf{~ c m}^{\mathbf{2}}\right) \text { at } \\
\mathbf{8 0 0} \mathbf{~}^{\mathbf{C}}\end{array}$ & $\begin{array}{c}\text { Average normalized } \\
\mathbf{R}_{\mathbf{p}}\left(\mathbf{O h m} \mathbf{~ c m}^{2}\right) \text { at } \\
\mathbf{8 0 0}^{\mathbf{0}} \mathbf{C}\end{array}$ & $\begin{array}{c}\text { Peak frequency } \\
\text { range }(\mathbf{H z}) \text { at } \\
\mathbf{8 0 0}{ }^{\mathbf{0}} \mathbf{C}\end{array}$ & $\begin{array}{c}\mathbf{E}_{\mathbf{a}}(\mathbf{e V}) \text { for } \\
\mathbf{R}_{\mathbf{p}}\end{array}$ \\
\hline 800 & $0.97(+/-0.08)$ & $0.73(+/-0.20)$ & $710-1780$ & $1.5(+/-0.1)$ \\
\hline 900 & $0.64(+/-0.04)$ & $0.50(+/-0.25)$ & $630-2820$ & $1.3(+/-0.1)$ \\
\hline 1200 & 0.86 & 1.03 & 100 & 1.0 \\
\hline
\end{tabular}

Table 4.4: Summary of results for the sintering study of aqueous LSM solution/YSZ symmetrical cells.

\begin{tabular}{|c|c|c|c|c|}
\hline $\begin{array}{c}\text { Sintering } \\
\text { Temperature } \\
\left({ }^{\mathbf{0}} \mathbf{C}\right)\end{array}$ & $\begin{array}{c}\text { Average normalized } \\
\mathbf{R}_{\mathbf{s}}\left(\mathbf{O h m} \mathbf{~ c m}^{2}\right) \text { at } \mathbf{8 0 0} \\
{ }^{\mathbf{0}} \mathbf{C}\end{array}$ & $\begin{array}{c}\text { Average normalized } \\
\mathbf{R}_{\mathbf{p}}\left(\mathbf{O h m} \mathbf{~ c m}^{2}\right) \text { at } \mathbf{8 0 0} \\
\mathbf{}^{\mathbf{0}} \mathbf{C}\end{array}$ & $\begin{array}{c}\text { Peak frequency } \\
\text { range (Hz) at } \\
\mathbf{8 0 0}{ }^{\mathbf{0}} \mathbf{C}\end{array}$ & $\begin{array}{c}\mathbf{E}_{\mathbf{a}}(\mathbf{e V}) \text { for } \\
\mathbf{R}_{\mathbf{p}}\end{array}$ \\
\hline 800 & $0.96(+/-0.06)$ & $0.44(+/-0.01)$ & $4000-10000$ & $1.1(+/-0.1)$ \\
\hline 900 & $0.78(+/-0.13)$ & $0.27(+/-0.14)$ & $3550-10000$ & $1.1(+/-0.1)$ \\
\hline 1000 & 0.82 & 0.66 & 890 & 0.9 \\
\hline
\end{tabular}

For both aqueous and organic solution based LSM cathodes sintered at $800{ }^{0} \mathrm{C}$, the $\mathrm{R}_{\mathrm{S}}$ values obtained at $800{ }^{0} \mathrm{C}$ were relatively high compared to the other sintering temperatures. This may be because $800{ }^{0} \mathrm{C}$ is not enough to well sinter the LSM on to YSZ electrolytes. Also, the $\mathrm{R}_{\mathrm{p}}$ values obtained for cathodes sintered at $800{ }^{0} \mathrm{C}$ are noticeably higher than the values obtained for cathodes sintered at $900{ }^{0} \mathrm{C}$. This again might be due to poor sintering of LSM particles at $800{ }^{\circ} \mathrm{C}$ which results in a comparatively poor cathode. For both LSM solutions, the cells sintered at $900{ }^{0} \mathrm{C}$ resulted in lower $\mathrm{R}_{\mathrm{p}}$ values compared to other sintering temperatures. However, when the solution based cathodes were sintered at a higher temperature $\left(1000{ }^{0} \mathrm{C}\right.$ or $\left.1200{ }^{0} \mathrm{C}\right)$, the $\mathrm{R}_{\mathrm{p}}$ values increased and the peak frequencies decreased noticeably as reported by Cronin et al. [5]. In their study, Cronin et al. [5] used 3D-FIB SEM tomography to study the cathode structures obtained after different sintering temperatures. Their LSM-YSZ composite powder cathodes sintered between $1075{ }^{0} \mathrm{C}-1175{ }^{0} \mathrm{C}$ showed the lowest $\mathrm{R}_{\mathrm{p}}$ values $\left(0.35-1.0 \mathrm{Ohmcm}^{2}\right)$ and highest impedance peak frequencies $(1000-100 \mathrm{~Hz})$ at $800{ }^{0} \mathrm{C}$. Their tomography images show a 
well sintered percolated network of LSM particles at the optimum firing temperatures $\left(1075{ }^{\circ} \mathrm{C}-1175{ }^{\circ} \mathrm{C}\right)$. Furthermore, values calculated from the 3D reconstructed electrodes show that the active TPB density was at a maximum $\left(\sim 8 \mu \mathrm{m}^{-2}\right)$ when the sintering temperatures were between $1075{ }^{\circ} \mathrm{C}-1175{ }^{\circ} \mathrm{C}$. Cathodes sintered at higher temperatures showed higher $R_{p}$ values and lower peak frequencies. 3D tomography image of the cathode sintered at $1325{ }^{\circ} \mathrm{C}$ shows particle coarsening and densification which reduces the calculated active TPB to $\sim 3 \mu \mathrm{m}^{-2}$ [5]. This study clearly shows that the higher sintering temperature results in particles coarsening which leads to reduced TPB density, increased $\mathrm{R}_{\mathrm{p}}$ values and low impedance peak frequencies. In other words, particle size is a very important contributor to the cathode performance. Sarikaya et al. [19] have studied how the microstructural evolution affects the SOFC performance using LSM paste/YSZ symmetrical cells. When they tested two LSM cathodes prepared using powders with different particle sizes $\left(d_{50}=1 \mu \mathrm{m}\right.$ and $\left.d_{50}=0.3 \mu \mathrm{m}\right)$, the latter cathode showed better performance with lower $R_{p}$ values; which further proves that small particles result in better performing cathode material.

Organic LSM solution based cathode sintered at $1200{ }^{\circ} \mathrm{C}$ and all the cathodes prepared using the aqueous LSM solution exhibited activation energy values $\sim 1 \mathrm{eV}$ for the oxygen reduction reaction, which is different to the activation energy values associated with LSM $(1.5 \mathrm{eV}-1.7 \mathrm{eV}$ or $1.3 \mathrm{eV})$ [3]. However, the activation energy values obtained for organic LSM solution based cathodes sintered at $800{ }^{\circ} \mathrm{C}$ and $900{ }^{\circ} \mathrm{C}$ are comparable to the reported activation energy values for LSM. The possible reasons for these observations will be discussed in Section 4.3 .8 of this chapter.

$R_{p}$ values obtained for all these solution based cathodes are around an order of magnitude lower compared to the powder based LSM cathodes. Also, the peak frequencies obtained for these cathodes are 2 to 3 orders magnitude higher than the peak frequencies obtained for LSM powder cathodes. As reported by Cronin et al. [5] and Sarikaya et al. [19], these observations might be related to particle size differences between the powder based and solution based LSM cathodes. 
SEM image of the LSM powder cathode sintered at $1200{ }^{\circ} \mathrm{C}$ (Figure 4.1) show a crystalline phase with grains in the $\mu \mathrm{m}$ range. However, the microstructure of the LSM solution cathode (Figure 4.10) is completely different from the structure of the LSM powder cathode (Figure 4.1). Instead of a crystalline phase, it shows an "amorphous sponge-like" structure at $5000 \mathrm{X}$ magnification. Also, there appear to be pores which might be continuous from the air/LSM interface to the YSZ electrolyte since these cathodes are extremely thin. We were not able to image these cathodes at higher magnifications due to instrumental limitations. However, Shiwoo Lee [20] at NETL-Morgantown have done a similar study where he deposited a solution of La-Sr-Co nitrates on different substrates followed by sintering at $\sim 900{ }^{\circ} \mathrm{C}$ and carried out SEM imaging. He observed similar amorphous structures on his material at low magnification SEM images. However, very high magnification (30000 X-100000 X) SEM images showed well defined grains in nm range. Therefore, we can assume that our solution based cathodes also consist of LSM particles that are in the $\mathrm{nm}$ range and hence results in lower $\mathrm{R}_{\mathrm{p}}$ values and higher impedance peak frequencies compared to the LSM powder cathodes with particles in $\mu \mathrm{m}$ range. A cathode with smaller LSM particles have comparatively high TPB area and hence a higher number of active sites for oxygen reduction reaction to occur, which results in a cathode with high performance.

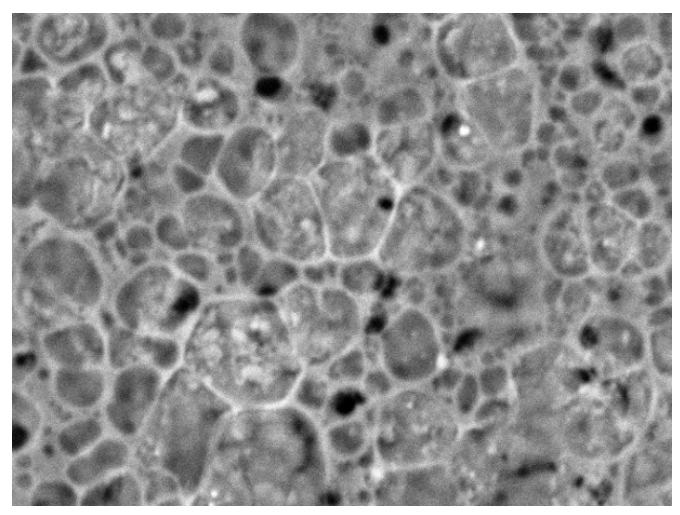

Figure 4.10: ESEM image of an organic LSM cathode sintered at 800 ${ }^{0} \mathrm{C}$ for 1 hour, $5000 \mathrm{X}$ magnification, $900{ }^{\circ} \mathrm{C}$ imaging temperature.

\section{Summary:}

Note that this summary is for solution based LSM cathodes with Ag current collectors.

- Lowest $\mathrm{R}_{\mathrm{p}}$ values were obtained for both solution based LSM cathodes sintered at $900{ }^{0} \mathrm{C}$. 
- Solution based cathodes sintered at higher temperatures $\left(1000{ }^{0} \mathrm{C}\right.$ or $\left.1200{ }^{0} \mathrm{C}\right)$ resulted in relatively high $\mathrm{R}_{\mathrm{p}}$ values and low peak frequencies.

- Organic solution based LSM cathodes sintered at $800{ }^{\circ} \mathrm{C}$ and $900{ }^{0} \mathrm{C}$ yielded activation energies around $1.5(+/-0.1) \mathrm{eV}$ and $1.3(+/-0.1) \mathrm{eV}$ respectively.

- Organic solution based LSM cathodes sintered at $1200{ }^{\circ} \mathrm{C}$ yielded activation energies around $1.0 \mathrm{eV}$.

- Aqueous solution based LSM cathodes sintered at both $800{ }^{\circ} \mathrm{C}$ and $900{ }^{\circ} \mathrm{C}$ yielded activation energies around $1.1(+/-0.1) \mathrm{eV}$.

- Aqueous solution based LSM cathodes sintered at $1000{ }^{\circ} \mathrm{C}$ yielded activation energies around $0.9 \mathrm{eV}$.

- Microstructure of powder based LSM cathode shows a crystalline phase with grains in the $\mu \mathrm{m}$ range while the solution based LSM cathodes show an amorphous like phase (with nm range grains hypothesized).

\subsubsection{Aging Study of LSM solution/YSZ symmetrical cells with Ag current collectors \\ Experimental:}

As mentioned in Section 4.3.4, LSM solution/YSZ symmetrical cells were prepared and characterized using the aging protocol mentioned in section 4.2.2.

\section{Results and Discussion:}

The aging studies of all the aqueous and organic LSM solution cathodes (with Ag current collectors) sintered at $800{ }^{\circ} \mathrm{C}$ and $900{ }^{\circ} \mathrm{C}$ showed similar aging patterns. Therefore, only the data obtained for organic LSM solution sintered at $900{ }^{\circ} \mathrm{C}$ cathode is shown in Figures 4.11 and 4.12. The data obtained for the other cells are presented in the Appendix A. 

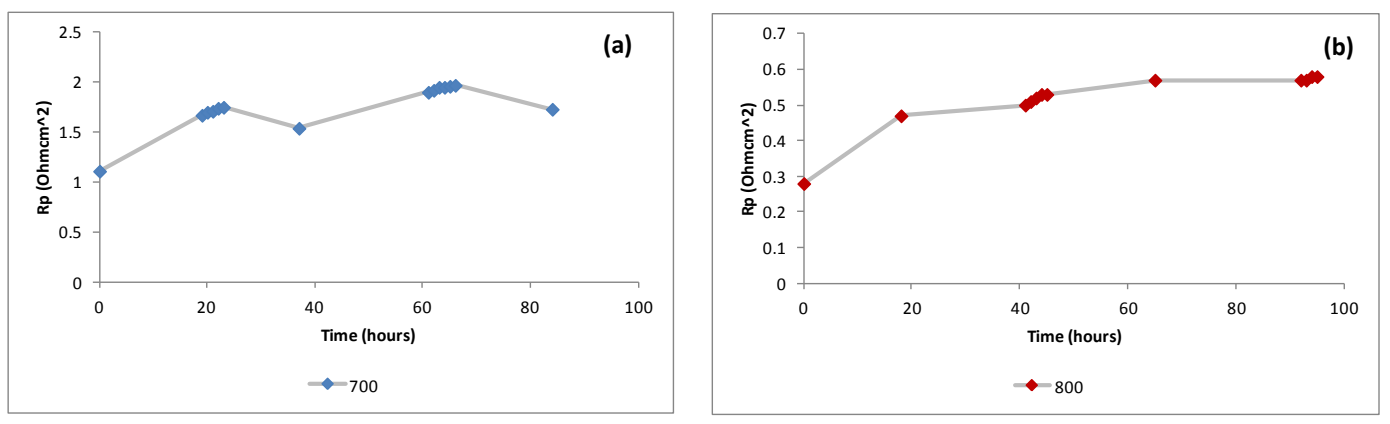

Figure 4.11: Polarization resistances recorded over time during the aging experiment for organic LSM solution cathode (with Ag current collector) sintered at $900{ }^{\circ} \mathrm{C}$ on YSZ at (a) $700{ }^{\circ} \mathrm{C}$ and (b) $800{ }^{\circ} \mathrm{C}$. This figure shows the cathode behavior vs. time over the entire experiment.
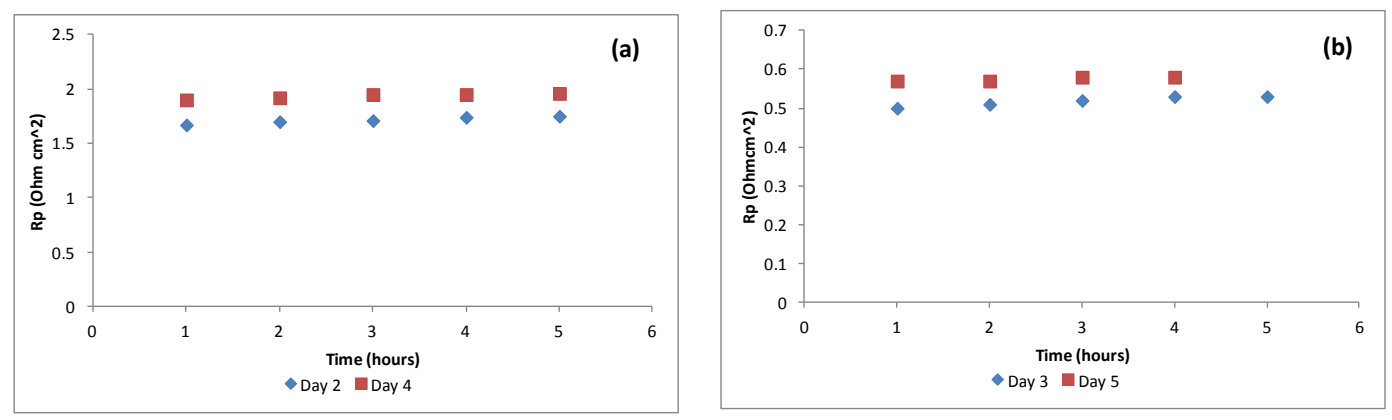

Figure 4.12: Polarization resistances recorded at (a) $700{ }^{0} \mathrm{C}$ and (b) $800{ }^{\circ} \mathrm{C}$ for aging of organic LSM solution cathode (with Ag current collector) sintered at $900{ }^{\circ} \mathrm{C}$ on YSZ. This figure shows the cathode behavior vs. time from the temperature change. At the beginning of Day 2 and Day 4, the cell temperature was dropped from $800{ }^{\circ} \mathrm{C}$ to $700{ }^{0} \mathrm{C}$. At the beginning of Day 3 and Day 5, the cell temperature was raised from $700{ }^{0} \mathrm{C}$ to 800 ${ }^{0} \mathrm{C}$.

With aging, the $\mathrm{R}_{\mathrm{p}}$ values recorded both at $700{ }^{\circ} \mathrm{C}$ and $800{ }^{\circ} \mathrm{C}$ increased slightly (or stayed constant). We did not observe reproducible $R_{p}$ values or reversible thermal aging patterns as reported for $\mathrm{LSM}$ powder cathodes [6]. The $\mathrm{R}_{\mathrm{p}}$ values measured at $800{ }^{0} \mathrm{C}$ on Day 5 eventually reached a constant value which might be because the cell has stopped undergoing the initial irreversible thermal aging. An interesting feature observed in all these data is the following. After aging the cell overnight at $700{ }^{0} \mathrm{C}$ (at the end of Day 2 and Day 4), the next $R_{p}$ value measured was smaller than the preceding $R_{p}$ value. However, when the cell was aged overnight at $800{ }^{0} \mathrm{C}$, the measured $\mathrm{R}_{\mathrm{p}}$ values increased. Assuming that LSM is the active cathode material, this might occur if the cation desegregation is 
favored at the lower temperature $\left(700{ }^{\circ} \mathrm{C}\right)$ which results in an active cathode surface and hence lower polarization resistance as Caillol et al. [10] have reported.
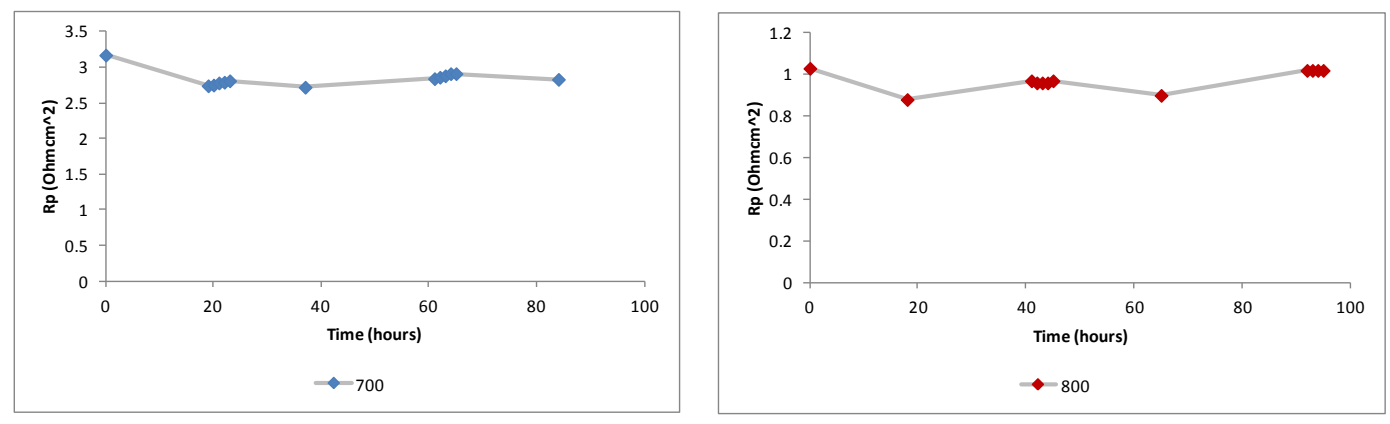

Figure 4.13: Polarization resistances recorded over time during the aging experiment for organic LSM solution cathode (with Ag current collector) sintered at $1200{ }^{\circ} \mathrm{C}$ on YSZ. This figure shows the cathode behavior vs. time over the entire experiment.
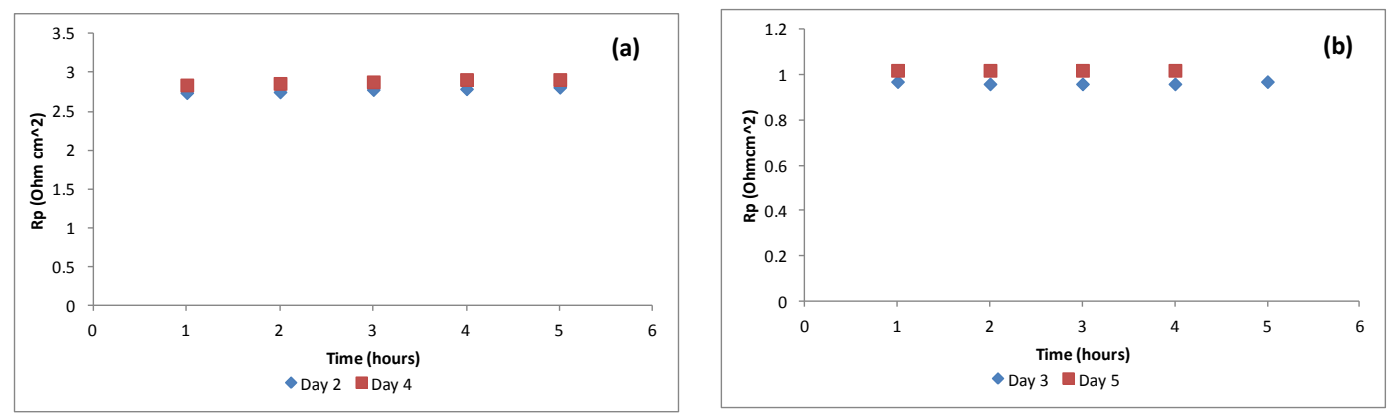

Figure 4.14: Polarization resistances recorded at (a) $700{ }^{\circ} \mathrm{C}$ and (b) $800{ }^{\circ} \mathrm{C}$ for aging of organic LSM solution cathode (with Ag current collector) sintered at $1200{ }^{\circ} \mathrm{C}$ on YSZ. This figure shows the cathode behavior vs. time from the temperature change. At the beginning of Day 2 and Day 4, the cell temperature was dropped from $800{ }^{\circ} \mathrm{C}$ to 700 ${ }^{0} \mathrm{C}$. At the beginning of Day 3 and Day 5, the cell temperature was raised from $700{ }^{0} \mathrm{C}$ to $800{ }^{\circ} \mathrm{C}$.

The aging patterns observed for organic LSM solution cathode (with Ag current collector) sintered at $1200{ }^{\circ} \mathrm{C}$ (Figures 4.13 and 4.14) are completely different from the aging patterns observed for other solution based cathodes. The $\mathrm{R}_{\mathrm{p}}$ values measured at both temperatures were approximately reproducible and constant. However, we did not observe the decreasing trend of $\mathrm{R}_{\mathrm{p}}$ values at $800{ }^{\circ} \mathrm{C}$, as reported by Abernathy et al.[6]. Since this cathode was sintered at a higher temperature $\left(1200{ }^{\circ} \mathrm{C}\right)$, it must have already undergone irreversible aging, which results in constant $\mathrm{R}_{\mathrm{p}}$ values during the aging study. 


\subsubsection{Deconvolution studies of LSM solution/YSZ symmetrical cells with Ag current collectors}

Deconvolution of impedance data collected for all solution based LSM cathodes with Ag current collectors resulted in a well-defined sharp peak at higher frequencies ( $\mathrm{kHz}$ range) which could be well fitted with a LR(RQ) circuit which has one or two elements. Figure 4.15 shows the deconvoluted data and the simulated data fit for an organic LSM solution based cathode sintered on YSZ at $900{ }^{\circ} \mathrm{C}$ for 1 hour. The cell was characterized using $\mathrm{Ag}$ current collectors and Ag wires. Deconvoluted data (blue) and the simulation result obtained using the equivalent circuit (red) fitting show a very good agreement and the fitting parameters are shown in table 4.5.

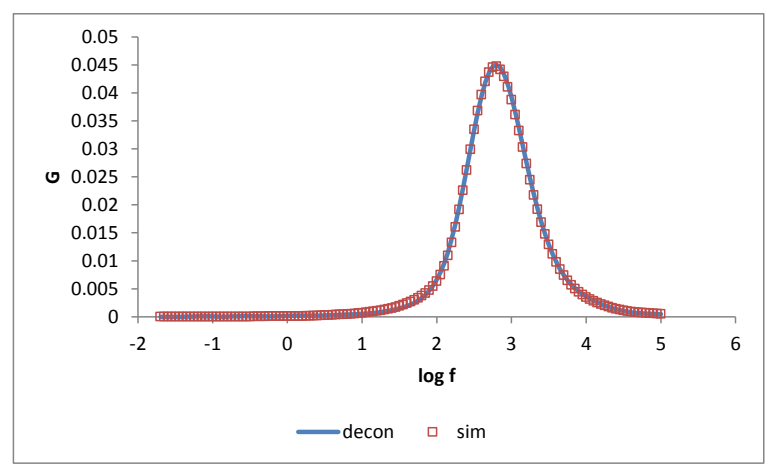

Figure 4.15: Deconvoluted (blue) and simulated (red) data at $800{ }^{0} \mathrm{C}$ for $\mathrm{Ag} /$ organic LSM/YSZ symmetrical cell sintered at $900{ }^{\circ} \mathrm{C}$.

A typical LSM powder cathode yields impedance data that has to be fitted using multiple equivalent circuit elements and also yields peak frequencies around 1-10 $\mathrm{Hz}$ range. However, the LSM solution based cathodes not only resulted in high peak frequencies but also less complex deconvoluted spectra that can be fitted using one/two equivalent circuit elements.

These solution based electrodes that are in contact with YSZ electrolyte are very thin $(\sim 2$ D) structures. Therefore, there might be a possibility for the metal current collector to penetrate the LSM layer and come into direct contact with the electrolyte and behave as a cathode. Due to this reason, it was decided to further investigate these solution based LSM cathodes with different current collectors and to study the effect of current collector on their performance. 
Table 4.5: Normalized fitting parameters at $800{ }^{\circ} \mathrm{C}$ for Ag/organic LSM/YSZ symmetrical cell sintered at $900{ }^{\circ} \mathrm{C}$.

\begin{tabular}{|c|c|c|c|}
\hline Element & Parameter & Value & Units \\
\hline Series R & $\mathrm{R} 1$ & 0.64 & $\mathrm{Ohmcm}^{2}$ \\
\hline Inductance & $\mathrm{L}$ & $3.14 \mathrm{E}-07$ & $\mathrm{Hcm}^{2}$ \\
\hline RQ1 & $\mathrm{R} 2$ & 1.22 & $\mathrm{Ohmc}^{2}$ \\
\hline RQ2 & $\mathrm{R} 3$ & 0.24 & $\mathrm{Ohmcm} 2$ \\
\hline RQ1 & $\mathrm{n} 1$ & 0.793 & \\
\hline RQ2 & $\mathrm{n} 2$ & 0.966 & \\
\hline RQ1 & $\mathrm{f} 1$ & 779 & $\mathrm{~Hz}$ \\
\hline RQ2 & $\mathrm{f} 2$ & 423 & $\mathrm{~Hz}$ \\
\hline RQ1 & $\mathrm{Q} 1$ & $9.72 \mathrm{E}-04$ & \\
\hline RQ2 & $\mathrm{Q} 2$ & $2.05 \mathrm{E}-03$ & \\
\hline Polarization R & $\mathrm{R}_{\mathrm{p}}$ & 0.73 & $\mathrm{Ohmcm}^{2}$ \\
\hline Activation Energy for ORR & $\mathrm{E}_{\mathrm{a}}$ & $\begin{array}{c}1.3 \\
(+/-0.1)\end{array}$ & $\mathrm{eV}$ \\
\hline
\end{tabular}

\subsubsection{LSM solution/YSZ symmetrical cells with different metal current collectors}

An ideal current collector should not take part in the reactions taking place at the SOFC electrodes [21]. However, the current collection method and the material used as the current collector have a significant impact on the cell performance [22].

First, we prepared and characterized $\mathrm{Ag} / \mathrm{YSZ}$ and $\mathrm{Pt} / \mathrm{YSZ}$ symmetrical cells in order to study their impedance behavior. We attempted to prepare Au/YSZ symmetrical cells as well; however, Au showed very poor adhesion to the YSZ substrate during sintering. After that, we studied the impedance behavior of LSM solution electrodes with Pt and Au current collectors. The results in Chapter 02 - Sections $2.3(\mathrm{Pt} / \mathrm{YSZ}$ cells) and $2.5(\mathrm{Ag} / \mathrm{YSZ})$ cells are limited to just Rs and Rp values. This study includes the full impedance spectra for these metal/YSZ symmetrical cells.

\section{Experimental:}

The symmetrical cells that were electrochemically characterized at $800{ }^{\circ} \mathrm{C}, 750{ }^{\circ} \mathrm{C}$ and 700 ${ }^{0} \mathrm{C}$ using impedance spectroscopy were prepared as follows. After soaking the cell at 800 ${ }^{0} \mathrm{C}$ for $\sim 1$ hour, measurements were taken at each temperature. 
(i) $\mathrm{Ag}$ (thick)/YSZ symmetrical cell: As received Ag paste (Fuel Cell Materials) was used to paint thin Ag electrodes on YSZ electrolytes and dried at $450{ }^{0} \mathrm{C}$. Then, Ag wires were attached and the cell was heated to $800{ }^{\circ} \mathrm{C}$ to start collecting data at each temperature.

(ii) $\mathrm{Ag}$ (thin)/YSZ symmetrical cell: The commercial Ag paste $(\sim 0.1 \mathrm{~mL})$ was diluted with a thinner $(\sim 0.2 \mathrm{~mL})$ (SPI Pt paint thinner - butyl acetate) to make a less viscous diluted Ag paste which was used to paint very thin Ag electrodes on YSZ electrolytes and dried at $450{ }^{\circ} \mathrm{C}$. Then, $\mathrm{Ag}$ wires were attached and the cell was heated to $800{ }^{0} \mathrm{C}$ to start collecting data at each temperature.

(iii) $\mathrm{Ag}$ (powder)/YSZ symmetrical cell: A Ag paste was prepared by mixing a $\mathrm{Ag}$ powder ( 1 g) (Alfa Aesar, 0.7-1.3 micron) and the ink vehicle ( $\sim 1 \mathrm{~g})$ (from Dr. Sabolsky's laboratory) in order to obtain a Ag paste which was used to paint very thin Ag electrodes on YSZ electrolytes and sintered at $800{ }^{\circ} \mathrm{C}$ for 1 hour. Then, $\mathrm{Ag}$ wires were attached and the cell was heated to $800{ }^{\circ} \mathrm{C}$ to start collecting data at each temperature.

(iv) Pt/YSZ symmetrical cell: As received Pt paste (SPI-CHEM) was used to paint thin Pt electrodes on YSZ electrolytes and sintered at $900{ }^{0} \mathrm{C}$ for 1 hour. Then, $\mathrm{Au}$ wires were attached and the cell was heated to $800{ }^{0} \mathrm{C}$ to start collecting data at each temperature.

\section{$\underline{\text { Results and Discussion: }}$}
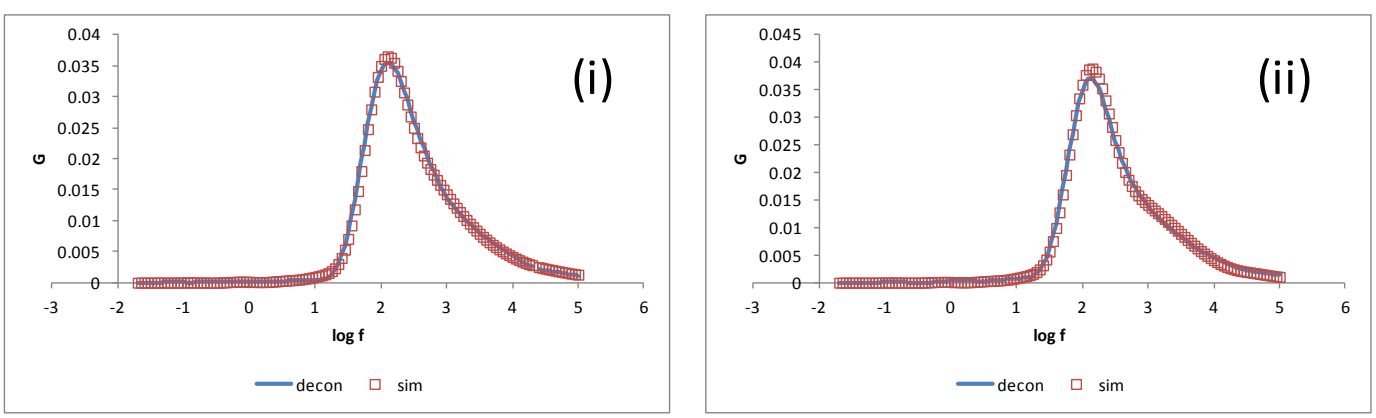

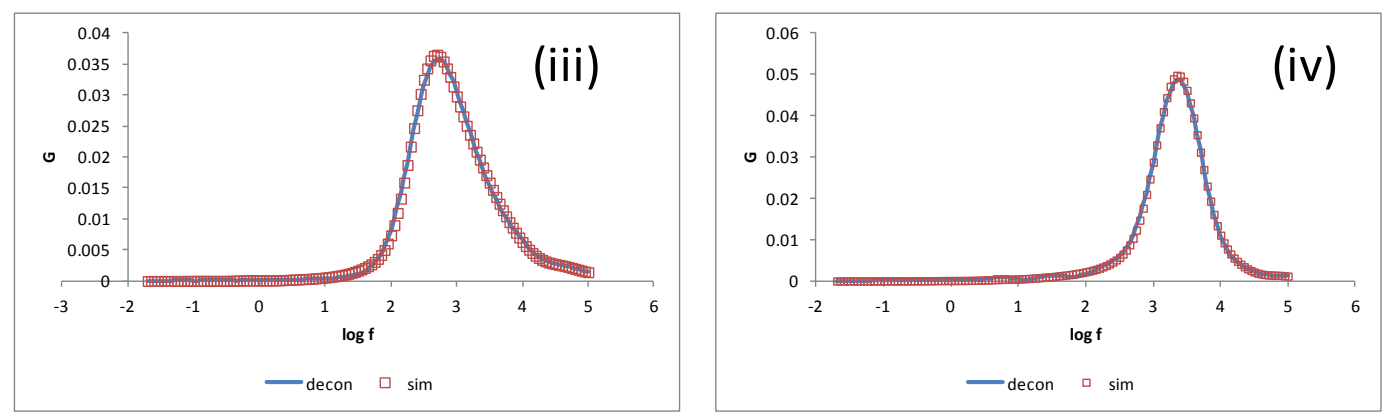

Figure 4.16: Deconvoluted (blue) and simulated (red) data at $800^{\circ} \mathrm{C}$ for (i) $\mathrm{Ag}$ (thick)/YSZ (ii) Ag (thin)/YSZ (iii) Ag powder/YSZ and (iv) Pt/YSZ symmetrical cells.

Based on the deconvolution spectra in Figure 4.16, an equivalent circuit which consists of a double fractal Gerischer element paired with an RQ element (parameters shown in Table 4.6) had to be used in order to fit the deconvoluted impedance data obtained for all three $\mathrm{Ag} / \mathrm{YSZ}$ symmetrical cells. Gerischer impedance arises when a chemical reaction is coupled with a diffusion step [23]. According to Boukamp and Bouwmeester [23], a slow dissociative adsorption step or a distributed charge transfer step coupled with surface diffusion would result in Gerischer impedance [23].

The peak frequencies for these spectra lie between $125-500 \mathrm{~Hz}$, values which are noticeably lower than the $\mathrm{kHz}$ peak frequencies observed for solution-deposited LSM with silver paste current collectors.

Sarikaya et al. [24] characterized a Ag/YSZ symmetrical cell prepared using a Ag paste (by mixing $\mathrm{Ag}$ powder with alpha-terpineol) and they reported $1.85 \mathrm{Ohmcm}^{2}$ as the measured $\mathrm{R}_{\mathrm{p}}$ value at $800{ }^{\circ} \mathrm{C}$. Furthermore, they have used an equivalent circuit consist of a resistor and a finite length Warburg element to fit their data.

The impedance data obtained for the Pt/YSZ symmetrical cell was very different from the $\mathrm{Ag} / \mathrm{YSZ}$ cells since the data fitting was achieved using a LR (RQ)2 equivalent circuit and the peak frequency lies around $3 \mathrm{kHz}$. 
Table 4.6: Normalized fitting parameters for $\mathrm{Ag} / \mathrm{YSZ}$ and $\mathrm{Pt} / \mathrm{YSZ}$ symmetrical cells at $800{ }^{0} \mathrm{C}$.

\begin{tabular}{|c|c|c|c|c|c|c|}
\hline \multicolumn{2}{|l|}{ Symmetrical Cells } & \multirow{2}{*}{$\begin{array}{l}\begin{array}{l}\text { Ag (thick) } \\
\text { /YSZ }\end{array} \\
\text { Value }\end{array}$} & \multirow{2}{*}{$\begin{array}{l}\begin{array}{l}\text { Ag(thin) } \\
\text { /YSZ }\end{array} \\
\text { Value }\end{array}$} & \multirow{2}{*}{$\begin{array}{l}\text { Ag(powder) } \\
\text { /YSZ } \\
\text { Value }\end{array}$} & \multirow{2}{*}{$\begin{array}{l}\text { Pt/YSZ } \\
\text { Value }\end{array}$} & \multirow[b]{2}{*}{ Units } \\
\hline Element & Parameter & & & & & \\
\hline Series R & $\mathrm{R} 1$ & 0.72 & 0.83 & 0.90 & 1.17 & $\mathrm{Ohmcm}^{2}$ \\
\hline Inductance & $\mathrm{L}$ & $3.26 \mathrm{E}-07$ & $4.18 \mathrm{E}-07$ & $4.20 \mathrm{E}-07$ & $4.32 \mathrm{E}-07$ & $\mathrm{Hcm}^{2}$ \\
\hline Ge & $\mathrm{R}$ & 0.84 & 0.50 & 1.43 & - & $\mathrm{Ohmcm}^{2}$ \\
\hline RQ1 & $\mathrm{R} 2$ & 0.11 & 0.08 & 0.73 & 14.23 & $\mathrm{Ohmcm}^{2}$ \\
\hline RQ2 & R3 & - & - & - & 0.61 & $\mathrm{Ohmcm}^{2}$ \\
\hline$\overline{R Q 1}$ & $\mathrm{n} 1$ & - & - & - & 0.854 & \\
\hline RQ2 & $\mathrm{n} 2$ & 0.684 & 0.727 & 0.730 & 0.569 & \\
\hline RQ1 & f1 & - & - & - & 2325 & $\mathrm{~Hz}$ \\
\hline RQ2 & $\mathrm{f} 2$ & 764 & 1666 & 1532 & 156 & $\mathrm{~Hz}$ \\
\hline$\overline{G e}$ & $\mathrm{f}$ & 150 & 155 & 471 & - & $\mathrm{Hz}$ \\
\hline Ge & $\mathrm{T}$ & $5.72 \mathrm{E}-04$ & $7.15 \mathrm{E}-04$ & $1.77 \mathrm{E}-04$ & - & $\mathrm{Ohmcm}^{2}$ \\
\hline Ge & $\mathrm{U}$ & 0.934 & 0.931 & 0.890 & - & \\
\hline Ge & $P$ & 0.514 & 0.595 & 0.717 & - & \\
\hline RQ1 & Q1 & - & - & - & $1.95 \mathrm{E}-05$ & \\
\hline RQ2 & Q2 & $2.73 \mathrm{E}-02$ & $1.47 \mathrm{E}-02$ & $1.69 \mathrm{E}-03$ & $3.23 \mathrm{E}-02$ & \\
\hline Total Polarization $\mathbf{R}$ & $\mathrm{R}_{\mathrm{p}}$ & 0.48 & 0.29 & 1.08 & 7.43 & $\mathrm{Ohmcm}^{2}$ \\
\hline $\begin{array}{ll}\text { Activation } & \text { Energy } \\
\text { for ORR } & \end{array}$ & $\mathrm{E}_{\mathrm{a}}$ & $\begin{array}{c}0.9 \\
(+/-0.0)\end{array}$ & $\begin{array}{c}0.9 \\
(+/-0.0)\end{array}$ & $\begin{array}{c}1.0 \\
(+/-0.0)\end{array}$ & $\begin{array}{c}1.9 \\
(+/-0.1)\end{array}$ & $\mathrm{eV}$ \\
\hline
\end{tabular}

The higher $\mathrm{R}_{\mathrm{s}}$ value obtained for Pt/YSZ symmetrical cell suggests that the Pt did not sinter well onto the YSZ substrate (as we have reported before in Chapter 02). Also, Pt cathode shows a higher $R_{p}$ value as well as a higher $E_{a}$ value for oxygen reduction reaction. The lowest $R_{p}$ value was obtained for the thin Ag cathode prepared using the diluted Ag paste and all the $\mathrm{Ag}$ cathodes resulted in an activation energy $\sim 0.9-1.0 \mathrm{eV}$ for the oxygen reduction reaction. However, Vladikova et al. [25] have reported the activation energy for the oxygen reduction reaction above $450{ }^{\circ} \mathrm{C}$ as $1.4 \mathrm{eV}$ for $\mathrm{Ag}$ cathodes. 


\section{Experimental:}

In order to further investigate this phenomenon, the following cells were prepared and characterized using impedance spectroscopy.

(v) Pt/organic LSM/YSZ symmetrical cell: Organic LSM solution was deposited on both sides of the YSZ electrolyte ( 10-20 uL total volume in multiple depositions of $\sim 5 \mathrm{uL}$ aliquots) and dried at $\sim 100{ }^{0} \mathrm{C}$, followed by sintering at $900{ }^{0} \mathrm{C}$ for 1 hour. Then, Pt paste (NETL) was painted on the LSM solution electrodes and sintered at $900{ }^{0} \mathrm{C}$ for 1 hour. The cell was characterized using Au wires connected to the Pt paste.

(vi) $\mathrm{Au} /$ organic LSM/YSZ symmetrical cell: Organic LSM solution was deposited on both sides of the YSZ electrolyte ( 10-20 uL total volume in multiple depositions of $\sim 5 \mathrm{uL}$ aliquots) and dried at $\sim 100{ }^{0} \mathrm{C}$, followed by sintering at $900{ }^{0} \mathrm{C}$ for 1 hour. Then, Au paste (Heraeus) was painted on the LSM solution electrodes and sintered at $800{ }^{0} \mathrm{C}$ for 1 hour. The cell was characterized using Au wires connected to the Pt paste.

Results and Discussion:
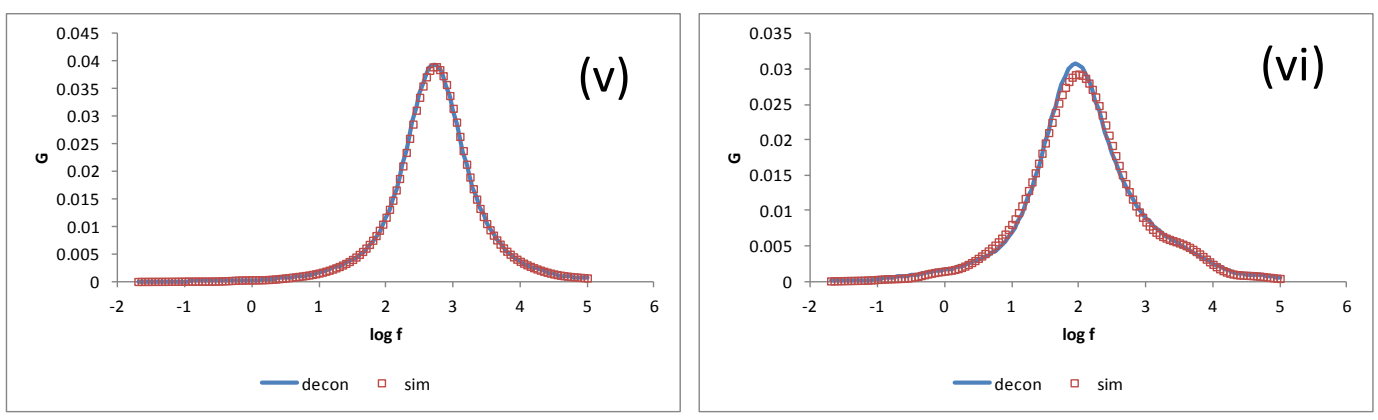

Figure 4.17: Deconvoluted (blue) and simulated (red) data at $800{ }^{\circ} \mathrm{C}$ for (v) $\mathrm{Pt} /$ organic LSM/YSZ (vi) Au/organic LSM/YSZ symmetrical cells. 
Table 4.7: Normalized fitting parameters for Pt/organic LSM/YSZ and Au/organic $\mathrm{LSM} / \mathrm{YSZ}$ symmetrical cells at $800{ }^{0} \mathrm{C}$.

\begin{tabular}{|l|l|l|l|l|}
\hline \multicolumn{2}{|l|}{ Symmetrical Cells } & $\begin{array}{l}\text { Pt/organic } \\
\text { LSM/YSZ }\end{array}$ & $\begin{array}{l}\text { Au/organic } \\
\text { LSM/YSZ }\end{array}$ & \\
\hline Element & Parameter & Value & Value & Units \\
\hline Series R & $\mathrm{R} 1$ & 0.99 & 0.82 & $\mathrm{Ohmcm}^{2}$ \\
\hline Inductance & $\mathrm{L}$ & $4.40 \mathrm{E}-07$ & $4.13 \mathrm{E}-07$ & $\mathrm{Hcm}^{2}$ \\
\hline RQ1 & $\mathrm{R} 2$ & 5.17 & 0.06 & $\mathrm{Ohmcm}^{2}$ \\
\hline RQ2 & $\mathrm{R} 3$ & - & 1.38 & $\mathrm{Ohmcm}^{2}$ \\
\hline RQ1 & $\mathrm{n} 1$ & 0.757 & 0.866 & \\
\hline RQ2 & $\mathrm{n} 2$ & - & 0.687 & \\
\hline RQ1 & $\mathrm{f} 1$ & 532 & 3912 & $\mathrm{~Hz}$ \\
\hline RQ2 & $\mathrm{f} 2$ & - & 98 & $\mathrm{~Hz}$ \\
\hline RQ1 & $\mathrm{Q} 1$ & $4.16 \mathrm{E}-04$ & $2.47 \mathrm{E}-03$ & \\
\hline RQ2 & $\mathrm{Q} 2$ & - & $8.80 \mathrm{E}-03$ & \\
\hline Total Polarization R & $\mathrm{R}_{\mathrm{p}}$ & 2.59 & 0.72 & $\mathrm{Ohmcm}$ \\
\hline $\begin{array}{l}\text { Activation Energy for } \\
\text { ORR }\end{array}$ & $\mathrm{E}_{\mathrm{a}}$ & $\begin{array}{l}1.7 \\
(+/-0.0)\end{array}$ & $\begin{array}{l}(1.1 \\
(+/-0.0)\end{array}$ & $\mathrm{eV}$ \\
\hline
\end{tabular}

The deconvolution spectra and fitting parameters used for Pt/organic LSM/YSZ and $\mathrm{Au} /$ organic LSM/YSZ symmetrical cells are presented in Figure 4.17 and Table 4.7. For both cells, an LR (RQ)2 equivalent circuit has to be used to obtain a reasonable fit to the data. The average activation energy for the oxygen reduction reaction on organic LSM cathode (sintered at $900{ }^{0} \mathrm{C}$ ) with Ag current collector was $1.3(+/-0.1) \mathrm{eV}$. However, it was $1.1 \mathrm{eV}$ with $\mathrm{Au}$ current collector and $1.7 \mathrm{eV}$ with Pt current collector while latter being more consistent with the reported values [3] for ORR on LSM. The peak frequencies for Pt/organic LSM/YSZ and Au/organic LSM/YSZ cells lie in the ranges of $500 \mathrm{~Hz}$ and 100 $\mathrm{Hz}$ respectively while it was in the $\mathrm{kHz}$ range for most $\mathrm{Ag}$ /organic LSM/YSZ symmetrical cells. However, the deconvolution spectrum of the Au/organic LSM/YSZ cell clearly shows that there is a small peak at around $\sim 3 \mathrm{kHz}$ which corresponds to a very small resistance. Furthermore, the Pt/organic LSM/YSZ symmetrical cell showed a significantly higher $\mathrm{R}_{\mathrm{p}}$ value compared to the other solution based LSM cathodes with Ag or Au current collectors. 
This study clearly shows that the performance of the LSM solution based cathodes vary with different current collectors. Therefore, the superior performance of the LSM solution based cathodes cannot be exclusively due to LSM but maybe due to a mixed performance between the LSM and the metal current collectors.

\subsection{8 "Mixed" Performance of solution based LSM cathodes with Ag current collectors}

For all the Ag cathodes prepared using different methods, we achieved activation energy $\sim 1$ $\mathrm{eV}$ for the oxygen reduction reaction (Table 4.6). In Section 4.3.4, table 4.4 reports $\sim 1 \mathrm{eV}$ activation energy for the oxygen reduction reaction on all the aqueous LSM solution based cathodes. We have stated that this value does not agree with typical LSM cathodes. The concentration of the aqueous LSM solution is $\sim 0.03 \mathrm{M}$ (compared to $0.1 \mathrm{M}$ of organic LSM solution) and only $\sim 15-20 \mathrm{uL}$ of the LSM solution is used to prepare the cathode, which means the amount of LSM on these (aqueous solution based) cathodes are significantly low. Then, a Ag paste layer is applied as the current collector on top of these pre-sintered LSM cathodes. According to these observed activation energies, there is a possibility that the Ag was acting as the cathode material while LSM must have assisted its performance as another catalyst as well as an aid to resist the agglomeration and retain the porosity of the cathode.

The organic LSM solution based cathode sintered at $1200{ }^{\circ} \mathrm{C}$ with Ag current collector also showed activation energy $\sim 1 \mathrm{eV}$ for the oxygen reduction reaction. Unlike the other solution based LSM/YSZ symmetrical cells, the impedance deconvolution spectrum for this cell showed two well defined peaks that are well apart, suggesting that there can be two different processes governing the oxygen reduction reaction (Figure 4.18). 


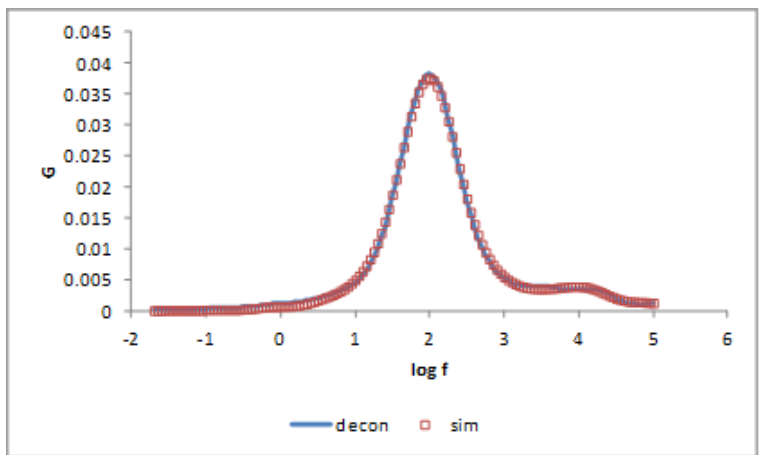

Figure 4.18: Deconvoluted (blue) and simulated (red) data at $800{ }^{\circ} \mathrm{C}$ for Ag/organic $\mathrm{LSM} / \mathrm{YSZ}$ symmetrical cell sintered at $1200{ }^{\circ} \mathrm{C}$.

Table 4.8: Normalized fitting parameters at $800{ }^{0} \mathrm{C}$ for Ag/organic $\mathrm{LSM} / \mathrm{YSZ}$ symmetrical cell sintered at $1200{ }^{\circ} \mathrm{C}$.

\begin{tabular}{|l|l|l|l|}
\hline \multicolumn{2}{|l|}{ Symmetrical Cell } & $\begin{array}{l}\text { Ag/Organic } \\
\text { LSM 1200/YSZ }\end{array}$ & \\
\hline Element & Parameter & Value & Units \\
\hline Series R & $\mathrm{R} 1$ & 0.86 & $\mathrm{Ohmcm}^{2}$ \\
\hline Inductance & $\mathrm{L}$ & $5.68 \mathrm{E}-07$ & $\mathrm{Hcm}^{2}$ \\
\hline RQ1 & $\mathrm{R} 2$ & 0.20 & $\mathrm{Ohmcm}^{2}$ \\
\hline RQ2 & $\mathrm{R} 3$ & 1.87 & $\mathrm{Ohmcm}^{2}$ \\
\hline RQ1 & $\mathrm{n} 1$ & 0.715 & \\
\hline RQ2 & $\mathrm{n} 2$ & 0.790 & \\
\hline RQ1 & $\mathrm{f} 1$ & 10495 & $\mathrm{~Hz}$ \\
\hline RQ2 & $\mathrm{f} 2$ & 98 & $\mathrm{~Hz}$ \\
\hline RQ1 & $\mathrm{Q} 1$ & $1.76 \mathrm{E}-03$ & \\
\hline RQ2 & $\mathrm{Q} 2$ & $3.36 \mathrm{E}-03$ & \\
\hline Total Polarization R & $\mathrm{R}_{\mathrm{p}}$ & 1.03 & $\mathrm{Ohmcm}$ \\
\hline $\begin{array}{l}\text { Activation Energy for } \\
\text { R2 }\end{array}$ & $\mathrm{E}_{\mathrm{a}, \mathrm{R} 2}$ & $\begin{array}{l}1.2 \\
(+/-0.0)\end{array}$ & $\mathrm{eV}$ \\
\hline $\begin{array}{l}\text { Activation Energy for } \\
\text { R3 }\end{array}$ & $\mathrm{E}_{\mathrm{a}, \mathrm{R} 3}$ & $\begin{array}{l}1.0 \\
(+/-0.0)\end{array}$ & $\mathrm{eV}$ \\
\hline $\begin{array}{l}\text { Activation Energy for } \\
\text { ORR }\end{array}$ & $\mathrm{E}_{\mathrm{a}}$ & $\begin{array}{l}1.0 \\
(+/-0.0)\end{array}$ & $\mathrm{eV}$ \\
\hline
\end{tabular}


The fitting parameters (listed in Table 4.8) can be used to calculate the activation energies associated with different processes as $1.0 \mathrm{eV}$ for the main process (which defines the total activation energy for the ORR as $\sim 1.0 \mathrm{eV}$ ) and $1.2 \mathrm{eV}$ for the process which shows a lower contribution to the overall cathode reaction. We can suggest that the RQ1 element with the $1.2 \mathrm{eV}$ activation energy is associated with the LSM particles. The $1200{ }^{0} \mathrm{C}$ sintering temperature must have resulted in very active particles of a crystalline LSM phase (evident by high peak frequency). However, when the Ag current collector is applied, a large number of Ag particles would be directly in contact with YSZ and may take part in the cathodic reaction as the main contributor (RQ2) while LSM particles also participate in the reaction. At the same time, LSM particles would inhibit the Ag agglomeration and maintain a continuous distribution of $\mathrm{Ag}$ particle network to assure better cathode performance over time, as observed by the aging study (Figure 4.12).

Sholklapper et al. [26] have carried out a research to study the Ag and Ag-LSM infiltrated Scandia Stabilized Zirconia (SSZ) cathodes. They observed that the Ag-LSM infiltrated cathode performed better than the Ag infiltrated cathode. Also, their SEM images clearly showed how the nano scale LSM particles were separating the nanoscale Ag particles. Furthermore, they have identified the length of the oxygen diffusion path (in a thick $\mathrm{Ag}$ layer) as the limiting factor for ORR. Therefore, they infiltrated a $\mathrm{nm}$ thick $\mathrm{Ag}$ layer in order to have short oxygen diffusion paths and hence higher cathode activity.

Sarikaya et al. [24] have reported a study where they mixed Ag and LSM powders to prepare a better performing current collector. Their purpose of mixing LSM with Ag was to prevent the densification of Ag layer and to maintain sufficient porosity over time. We have reproduced their experiment in order to investigate how this Ag-LSM mixture would behave as a cathode.

\section{Experimental:}

LSM powder (LSM 20-P, $\mathrm{d}_{50} \sim 1 \mu \mathrm{m}$, Fuel Cell Materials) $(0.25 \mathrm{~mL})$, Ag powder (0.7-1.3 micron, Alfa Aesar) (1 mL) and ink vehicle ( $1 \mathrm{~g})$ [24] (from Dr. Sabolsky's laboratory) were "ball milled" together using the WIG-L-BUG. Then, the resulting paste was used to paint very thin electrodes on both sides of an YSZ electrolyte which was sintered at $800{ }^{\circ} \mathrm{C}$ 
for $1 \mathrm{hr}$. Then, this symmetrical cell was characterized by impedance spectroscopy (at 800 ${ }^{0} \mathrm{C}, 750{ }^{\circ} \mathrm{C}$ and $\left.700{ }^{\circ} \mathrm{C}\right)$ using $\mathrm{Ag}$ wires.

Results and Discussion:

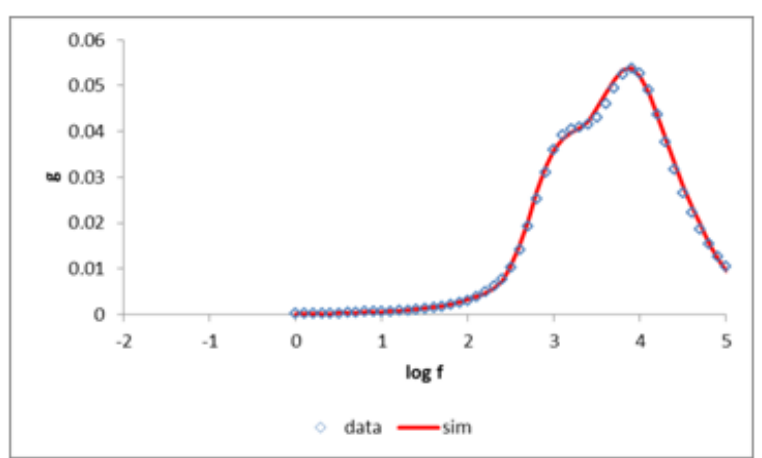

Figure 4.19: Deconvoluted and simulated data for Ag-LSM/YSZ symmetrical cells at $800{ }^{\circ} \mathrm{C}$.

Table 4.9: Normalized fitting parameters for Ag-LSM/YSZ symmetrical cell at $800{ }^{\circ} \mathrm{C}$.

\begin{tabular}{|l|l|l|l|}
\hline \multicolumn{2}{|l|}{ Symmetrical Cells } & Ag-LSM/YSZ & \\
\hline Element & Parameter & Value & Units \\
\hline Series R & $\mathrm{R} 1$ & 0.75 & $\mathrm{Ohmcm}^{2}$ \\
\hline Inductance & $\mathrm{L}$ & $3.21 \mathrm{E}-07$ & $\mathrm{Hcm}^{2}$ \\
\hline RQ1 & $\mathrm{R} 2$ & 1.31 & $\mathrm{Ohmcm}^{2}$ \\
\hline RQ2 & $\mathrm{R} 3$ & 0.19 & $\mathrm{Ohmcm}^{2}$ \\
\hline RQ1 & $\mathrm{n} 1$ & 0.693 & \\
\hline RQ2 & $\mathrm{n} 2$ & 0.954 & \\
\hline RQ1 & $\mathrm{f} 1$ & 7289 & $\mathrm{~Hz}$ \\
\hline RQ2 & $\mathrm{f} 2$ & 969 & $\mathrm{~Hz}$ \\
\hline RQ1 & $\mathrm{Q} 1$ & $4.50 \mathrm{E}-04$ & \\
\hline RQ2 & $\mathrm{Q} 2$ & $1.30 \mathrm{E}-03$ & \\
\hline Total Polarization R & $\mathrm{R}_{\mathrm{p}}$ & 0.75 & $\mathrm{Ohmcm}$ \\
\hline $\begin{array}{l}\text { Activation Energy for } \\
\text { ORR }\end{array}$ & $\mathrm{E}_{\mathrm{a}}$ & $\begin{array}{l}1.0 \\
(+/-0.0)\end{array}$ & $\mathrm{eV}$ \\
\hline
\end{tabular}


Deconvoluted data and simulated data fit (Figure 4.19) for the impedance of Ag-LSM cathode was achieved using a LR(RQ)2 equivalent circuit. The peak frequency for this data lies in the $\mathrm{kHz}$ region as well. The activation energy value (Table 4.9) for the oxygen reduction reaction is $1.0 \mathrm{eV}$, which is as same as the activation energy for oxygen reduction reaction on pure $\mathrm{Ag}$ cathode prepared using $\mathrm{Ag}$ powder and some of the solution based LSM cathodes with Ag current collectors.

Guo et al. [22] have conducted a very interesting study where they investigated the "electrochemical contribution of Ag current collector to the oxygen reduction reaction of BSCF". They report in their literature survey that the lowest $\mathrm{R}_{\mathrm{p}}$ values have always been achieved when Ag current collectors were used. Also, they report that the Ag alone did not perform well as a cathode in comparison to $\mathrm{Ba}_{0.5} \mathrm{Sr}_{0.5} \mathrm{Co}_{0.8} \mathrm{Fe}_{0.2} \mathrm{O}_{3-\delta}$ (BSCF). However the BSCF cathode with Ag current collectors performed significantly better than the cathode with the Au current collectors. Therefore, they suspected that Ag particles migrate into the BSCF cathode structure and enhance its performance. However, their detailed characterization using EDX did not show any signs of such migrations.

\subsubsection{LSM solution/HIONIC® symmetrical cells}

To study whether the electrolyte has an effect on the performance of LSM solution cathodes, an experiment was carried out using a HIONIC electrolyte (Fuel Cell Materials). This is a patent pending electrolyte that is a mixture of Scandium oxide and Zirconium oxide. The vendor claims that this electrolyte has higher conductivity and strength than YSZ [27], [28].

\section{Experimental:}

Ag/organic LSM/HIONIC symmetrical cell: Organic LSM solution was deposited on both sides of the HIONIC electrolyte ( 10-20 uL total volume in multiple depositions of $\sim 5 \mathrm{uL}$ aliquots) and dried at $\sim 100{ }^{\circ} \mathrm{C}$, followed by sintering at $900{ }^{\circ} \mathrm{C}$ for 1 hour. Then, the cell was characterized using Ag paste current collectors and Ag wires. 
Results and Discussion:

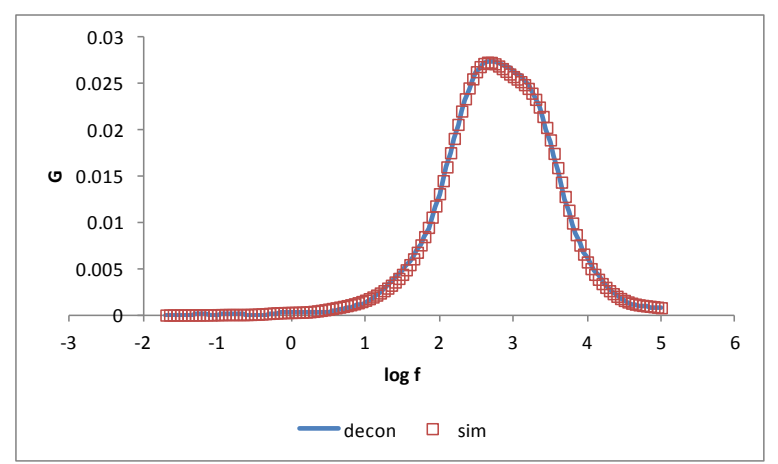

Figure 4.20: Deconvoluted and simulated data for Ag/ organic LSM/HIONIC symmetrical cells at $800{ }^{\circ} \mathrm{C}$.

Table 4.10: Normalized fitting parameters for Ag/ organic LSM/HIONIC symmetrical cell at $800{ }^{0} \mathrm{C}$.

\begin{tabular}{|l|l|l|l|}
\hline \multicolumn{2}{|l|}{ Symmetrical Cells } & $\begin{array}{l}\text { Ag/organic } \\
\text { LSM/HIONIC }\end{array}$ & \\
\hline Element & Parameter & Value & Units \\
\hline Series R & $\mathrm{R} 1$ & 0.43 & $\mathrm{Ohmcm}^{2}$ \\
\hline Inductance & $\mathrm{L}$ & $4.29 \mathrm{E}-07$ & $\mathrm{Hcm}^{2}$ \\
\hline RQ1 & $\mathrm{R} 2$ & 1.02 & $\mathrm{Ohmcm}^{2}$ \\
\hline RQ2 & $\mathrm{R} 3$ & 0.49 & $\mathrm{Ohmcm}^{2}$ \\
\hline RQ1 & $\mathrm{n} 1$ & 0.738 & \\
\hline RQ2 & $\mathrm{n} 2$ & 0.821 & \\
\hline RQ1 & $\mathrm{f} 1$ & 362 & $\mathrm{~Hz}$ \\
\hline RQ2 & $\mathrm{f} 2$ & 2154 & $\mathrm{~Hz}$ \\
\hline RQ1 & Q1 & $3.28 \mathrm{E}-03$ & \\
\hline RQ2 & Q2 & $8.36 \mathrm{E}-04$ & \\
\hline Total Polarization R & $\mathrm{R}_{\mathrm{p}}$ & 0.75 & $\mathrm{Ohmcm}$ \\
\hline $\begin{array}{l}\text { Activation Energy for } \\
\text { ORR }\end{array}$ & $\mathrm{E}_{\mathrm{a}}$ & $\begin{array}{l}1.3 \\
(+/-0.0)\end{array}$ & $\mathrm{eV}$ \\
\hline
\end{tabular}

As shown in Figure 4.20 and Table 4.10, impedance data obtained for the Ag/ organic LSM/HIONIC symmetrical cell was fitted using a LR(RQ)2 equivalent circuit. As claimed by the manufacturer, this electrolyte is more conductive than the YSZ electrolyte since it produced a $\mathrm{R}_{\mathrm{S}}$ value of $0.43 \mathrm{Ohmcm}^{2}$ at $800{ }^{\circ} \mathrm{C}$, compared to $\sim 0.7-0.8 \mathrm{Ohm} \mathrm{cm}^{2}$ for YSZ. 
Other than that, the $\mathrm{R}_{\mathrm{p}}$ values, peak frequencies and activation energy value for the oxygen reduction reaction are comparable to the other $\mathrm{Ag}$ / organic LSM/YSZ symmetrical cells sintered at $900^{\circ} \mathrm{C}$, which means that the performance of the solution based LSM cathodes are independent of the electrolyte.

\subsubsection{Ag/organic LSM/YSZ symmetrical cells with different oxygen partial pressures}

The original objective of this study was to investigate the performance of solution based LSM cathodes in different oxygen partial pressures in order to propose an oxygen reduction mechanism on solution based LSM cathodes. However, since it is apparent that the Ag current collector participates in the oxygen reduction reaction of the LSM solution cathode, these results are presented as a preliminary study of Ag-LSM "composite" cathodes that needs to be investigated further.

\section{Experimental:}

Organic LSM solution was deposited on both sides of the YSZ electrolyte ( $\sim 10-20 \mathrm{uL}$ total volume in multiple depositions of $\sim 5 \mathrm{uL}$ aliquots) and dried at $\sim 100{ }^{0} \mathrm{C}$, followed by sintering at $900{ }^{0} \mathrm{C}$ for 1 hour. Then, $\mathrm{Ag}$ paste was painted on the LSM solution electrodes and sintered at $800{ }^{0} \mathrm{C}$ for 1 hour. The cell was mounted using $\mathrm{Au}$ wires in the Electrochemical Conductivity Relaxation (ECR) apparatus at NETL and the impedance data were collected as a function of oxygen partial pressures $\left(\mathrm{pO}_{2}\right)$ (from 0.2 atm to 0.002 atm (down) and from 0.002 atm to $0.2 \mathrm{~atm}$ (up)) at both $750{ }^{\circ} \mathrm{C}$ and $800{ }^{0} \mathrm{C} . \mathrm{N}_{2}$ was used to control the required oxygen partial pressures.

\section{Results and Discussion:}

An equivalent circuit consists of two RQ elements were needed to fit the impedance data. The polarization resistances increased with the decreasing $\mathrm{pO}_{2}$ levels (Figure 4.21). This trend is consistent with pure LSM cathode studies in the literature [30] and the dependence of the polarization resistance on $\mathrm{pO}_{2}$ level is often used as a parameter in the discussion of oxygen reduction kinetics. Given a mechanism, one can derive the predicted exponent and the measured value allows elimination of possible mechanisms. 
The $\log \mathrm{Rp}$ vs $\log \mathrm{pO}_{2}$ plot (Figure 4.21) yielded an average slope $\sim-0.3$ to -0.4. Given the changes in slope in the plot for decreasing and increasing $\mathrm{pO}_{2}$, the average slope has a large uncertainty and it is difficult to compare this value to slopes predicted by mechanisms. The activation energy value calculated using resistance values measured at $800{ }^{\circ} \mathrm{C}$ and $750{ }^{\circ} \mathrm{C}$ (for 0.2 atm $\mathrm{pO}_{2}$ ) is $1.8 \mathrm{t}-0.3 \mathrm{eV}$. Siebert et al. [30] have reported a $1.8 \mathrm{eV}$ activation energy and a slope $\sim-0.5$ for their study on pin-shaped LSM cathodes with different oxygen partial pressures. Van Herle et al.'s [31] study on porous LSM cathodes report a slope of 0.53 and an activation energy of $2.11 \mathrm{eV}$ for a $\mathrm{pO}_{2}$ range of $10^{-4} \mathrm{~atm}-1 \mathrm{~atm}$ at $700{ }^{\circ} \mathrm{C}-$ $900{ }^{\circ} \mathrm{C}$. Also, Co and Birss [32] report a slope of -0.5 for porous LSM-YSZ cathodes $\left(\mathrm{pO}_{2}\right.$ $\left.=0.01-1 \mathrm{~atm}, \mathrm{~T}=600{ }^{\circ} \mathrm{C}\right)$ and a slope of $\sim 1$ for dense LSM cathodes $\left(\mathrm{pO}_{2}=0.03-1 \mathrm{~atm}\right.$, $\mathrm{T}=800{ }^{\circ} \mathrm{C}$ ). Murray et al. [33] reports a slope of -0.16 and an activation energy of $1.6 \mathrm{eV}$ $\left(\mathrm{pO}_{2}=10^{-3}-1 \mathrm{~atm}, \mathrm{~T}=550{ }^{\circ} \mathrm{C}-850{ }^{\circ} \mathrm{C}\right)$ for pure LSM cathodes, and a slope of -0.29 and an activation energy of $1.49 \mathrm{eV}$ for LSM-YSZ composite cathodes. Furthermore, they state that the high activation energy and weak $\mathrm{pO}_{2}$ dependence can be attributed to dissociative oxygen adsorption rate limiting steps [33]. Ostergard and Mogensen [34] also report a slope of $\sim-0.3$ for their $\mathrm{pO}_{2}$ studies of LSM and the value is attributed to disscociative adsorption of oxygen.

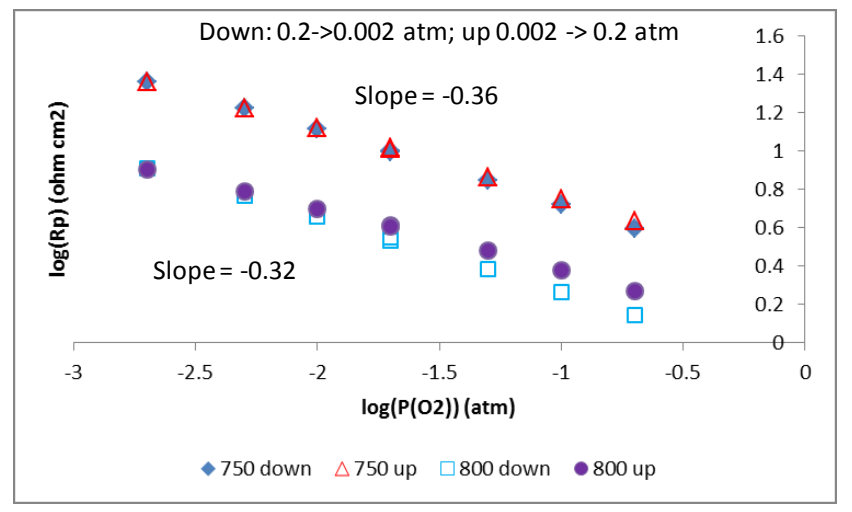

Figure 4.21: Relationship between the oxygen partial pressure and the polarization resistance of a $\mathrm{Ag}$ / organic LSM/YSZ symmetrical cell. Polarization resistances recorded from $0.2 \mathrm{~atm}$ to $0.002 \mathrm{~atm}$ (down) and from $0.002 \mathrm{~atm}$ to $0.2 \mathrm{~atm}$ (up) at $750{ }^{\circ} \mathrm{C}$ and 800 ${ }^{0} \mathrm{C}$ are shown.

The impedance spectra evolved from a symmetrical arc at high $\mathrm{pO}_{2}$ to a distinctly asymmetrical arc at low $\mathrm{pO}_{2}$. All impedance data were fitted using a 2RQ equivalent 
circuit. The changes in the resistances for the two RQ elements with respect to $\log \mathrm{pO}_{2}$ were not consistent. This result may have been caused by the difficulty in separating the two arcs consistently using the nonlinear regression fitting when they overlap extensively. Consequently, the two arcs cannot be assigned to two processes in each electrode or to different behavior of each of the two electrodes.

\subsection{Deconvolution study of LSM infiltrated YSZ cathodes}

The performance of LSM infiltrated YSZ cathodes (with LSM current collectors) are extensively discussed in Chapter 03 of this dissertation. In this section, the deconvolution analysis of impedance spectra for those cathodes (mentioned in Chapter 03) and the results obtained for LSM infiltrated "improved" YSZ cathodes will be studied in detail.

Kungas et al. [35] have stated that the structural modifications either in infiltrated nanoparticles or the scaffold can result in a better performing SOFC cathode. Since the essentially 2-D LSM solution based cathodes resulted in comparatively low polarization resistances, one approach was to use a conventional YSZ powder scaffold that is relatively thin. The other approach was to create a YSZ scaffold by Hydrofluoric acid etching (HF etching) [35] of the commercially bought YSZ electrolyte.

\section{Experimental:}

The two LSM infiltrated YSZ scaffolds were prepared as follows:

(i) Sample 1: YSZ powder (YSZ8-TC, surface area: $144 \mathrm{~m}^{2} / \mathrm{g}$ ), ink vehicle (from Dr. Sabolsky's group) and graphite powder ( $\sim 325$ mesh,Alfa Aesar) were mixed together (3:4:1 by weight) and "ball-milled" in a WIG-LBUG. Then, this paste was used to paint very thin YSZ scaffolds ( $\sim 10 \mu \mathrm{m}$ after sintering) on both sides of a YSZ electrolyte and sintered at $1550{ }^{\circ} \mathrm{C}$ for 2 hours. Then, the scaffolds were infiltrated with organic LSM solution ( $\sim 20 \mu \mathrm{L}, 10$ infiltration steps) (while firing at $450{ }^{\circ} \mathrm{C}$ after each infiltration of $2 \mu \mathrm{L}$ ), followed by final sintering at $800{ }^{\circ} \mathrm{C}$ for 1 hour. The cell was characterized using Ag wires and Ag current collectors. 
(ii) Sample 2: An area on the YSZ electrolyte (defined by varnish) was covered with concentrated $\mathrm{HF}$ acid and was etched at room temperature for $\sim 3$ hours. After washing, the HF etching was repeated on the other side. The surface was lightly brushed and sonicated in water to remove all the etched particles from the surface. The HF covered areas were visibly roughened and not shiny compared to the varnish covered area. Then, varnish was applied again on the YSZ electrolyte to define the HF etched area and organic LSM solution $(\sim 10 \mathrm{uL})$ was deposited on both sides and fired at $900{ }^{0} \mathrm{C}$ for 1 hour in order to prepare organic LSM/HF etched YSZ symmetrical cells. The cell was characterized using Ag wires and Ag current collectors.

\section{$\underline{\text { Results and Discussion: }}$}

The initiative to optimize these cathodes by improving the YSZ scaffold structure is a result of the deconvolution studies of the impedance data collected for LSM infiltrated YSZ scaffolds (with LSM current collectors) discussed in Chapter 03 (Figure 4.22).
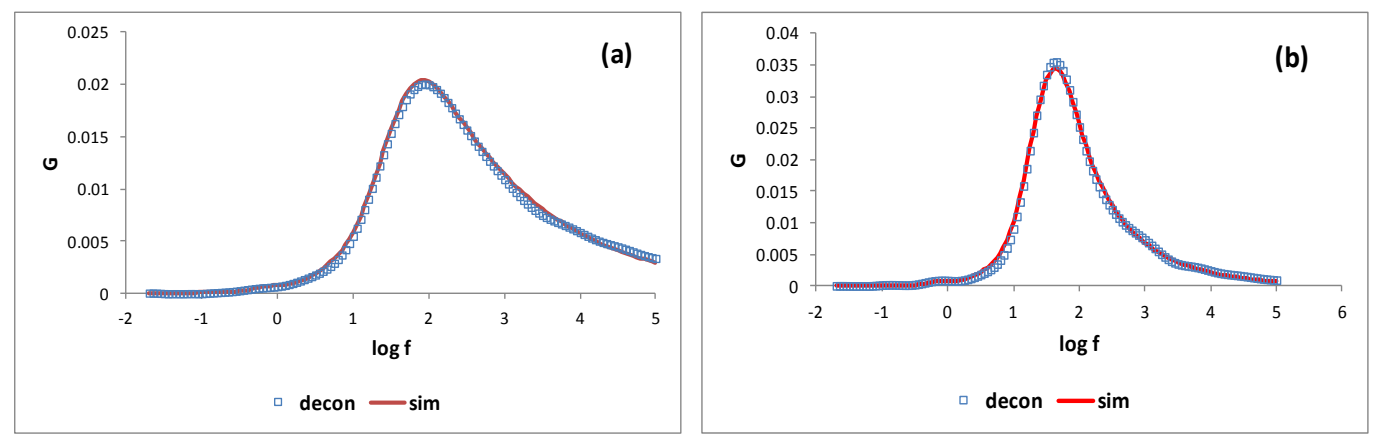

Figure 4.22: Deconvoluted and simulated data for LSM infiltrated YSZ nanofiber scaffold (a) and powder scaffold (b) with LSM current collectors at

Based on the deconvolution spectra shown in Figure 4.22, we used a double fractal Gerischer element in order to fit these data (parameters shown in Table 4.11). In general, Gerischer type impedance shapes tend to be present in relatively thick composite electrode structures. The cause for the Gerischer shape is believed to be the electrolyte resistance in the composite electrode structure [36]. The composite structure is analogous to that of a 
porous metal electrode in contact with a fluid electrolyte. The electrochemical reaction occurs along the walls of the pore. De Levie assumed that the pores were uniform cylinders and showed that the observed impedance was mathematically the same as a Gerischer impedance [37].

Table 4.11: Normalized fitting parameters for LSM infiltrated YSZ scaffolds with LSM current collectors at $800{ }^{\circ} \mathrm{C}$.

\begin{tabular}{|c|c|c|c|c|}
\hline \multicolumn{2}{|l|}{ Symmetrical Cells } & $\begin{array}{c}\text { LSM/LSM } \\
\text { infiltrated YSZ } \\
\text { nanofiber scaffold } \\
/ \text { YSZ }\end{array}$ & $\begin{array}{c}\text { LSM/LSM } \\
\text { infiltrated YSZ } \\
\text { powder scaffold } \\
/ \text { YSZ }\end{array}$ & \\
\hline Element & Parameter & Value & Value & Units \\
\hline Series R & $\mathrm{R} 1$ & 1.10 & 0.95 & $\mathrm{Ohm}^{2}$ \\
\hline Inductance & $\mathrm{L}$ & $4.20 \mathrm{E}-07$ & $4.91 \mathrm{E}-07$ & $\mathrm{Hcm}^{2}$ \\
\hline Ge & $\mathrm{R}$ & 0.21 & 0.30 & $\mathrm{Ohmcm}^{2}$ \\
\hline Ge & $\mathrm{f}$ & 113 & 51 & $\mathrm{~Hz}$ \\
\hline Ge & $\mathrm{T}$ & $1.54 \mathrm{E}-03$ & $2.23 \mathrm{E}-03$ & $\mathrm{Ohmcm}^{2}$ \\
\hline Ge & $\mathrm{U}$ & 0.760 & 0.848 & \\
\hline Ge & $\mathrm{P}$ & 0.384 & 0.584 & \\
\hline Total Polarization R & $\mathrm{R}_{\mathrm{p}}$ & 0.21 & 0.30 & $\mathrm{Ohmcm}$ \\
\hline $\begin{array}{c}\text { Activation Energy for } \\
\text { ORR }\end{array}$ & $\mathrm{E}_{\mathrm{a}}$ & $\begin{array}{c}1.3 \\
(+/-0.0)\end{array}$ & $\begin{array}{c}1.5 \\
(+/-0.1)\end{array}$ & $\mathrm{eV}$ \\
\hline
\end{tabular}

However, there are reports [38], [39] in which the authors demonstrated the use of a simple LR(RQ) equivalent circuit to fit the impedance data collected for LSM infiltrated YSZ cathodes.
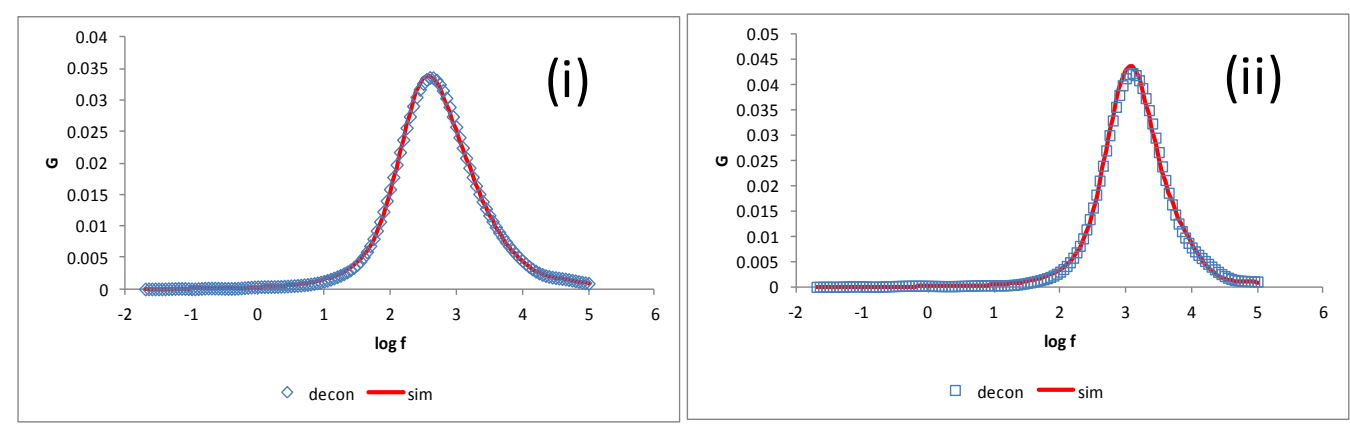

Figure 4.23: Deconvoluted and simulated data for LSM infiltrated improved YSZ scaffolds (types i and ii) with Ag current collectors at $800{ }^{\circ} \mathrm{C}$. 
The impedance data collected for both LSM infiltrated improved YSZ scaffolds (Figure 4.23 and Table 4.12) were fitted using a LR(RQ)2 equivalent circuit. As noted by Jensen et al. [36], thin composite electrodes do not exhibit marked Gerischer impedance. However, the thin YSZ scaffold yielded a slightly asymmetrical arc which could be fitted with a double fractal Gerischer impedance.

Table 4.12: Normalized fitting parameters for LSM infiltrated improved YSZ scaffolds with $\mathrm{Ag}$ current collectors at $800{ }^{\circ} \mathrm{C}$.

\begin{tabular}{|l|l|l|l|l|}
\hline \multicolumn{2}{|l|}{ Symmetrical Cells } & Sample (i) & Sample (ii) & \\
\hline Element & Parameter & Value & Value & Units \\
\hline Series R & $\mathrm{R} 1$ & 0.57 & 1.05 & $\mathrm{Ohmcm}^{2}$ \\
\hline Inductance & $\mathrm{L}$ & $2.73 \mathrm{E}-07$ & $1.03 \mathrm{E}-06$ & $\mathrm{Hcm}^{2}$ \\
\hline RQ1 & $\mathrm{R} 2$ & 0.50 & 1.26 & $\mathrm{Ohmcm}^{2}$ \\
\hline RQ2 & $\mathrm{R} 3$ & 1.93 & 0.12 & $\mathrm{Ohmcm}^{2}$ \\
\hline RQ1 & $\mathrm{n} 1$ & 0.812 & 0.827 & \\
\hline RQ2 & $\mathrm{n} 2$ & 0.702 & 0.910 & \\
\hline RQ1 & $\mathrm{f} 1$ & 298 & 1158 & $\mathrm{~Hz}$ \\
\hline RQ2 & $\mathrm{f} 2$ & 945 & 5688 & $\mathrm{~Hz}$ \\
\hline RQ1 & $\mathrm{Q} 1$ & $4.38 \mathrm{E}-03$ & $4.92 \mathrm{E}-04$ & \\
\hline RQ2 & $\mathrm{Q} 2$ & $4.64 \mathrm{E}-03$ & $5.87 \mathrm{E}-04$ & \\
\hline Total Polarization R & $\mathrm{R}_{\mathrm{p}}$ & 0.49 & 0.71 & $\mathrm{Ohmcm}$ \\
\hline $\begin{array}{l}\text { Activation Energy } \\
\text { for ORR }\end{array}$ & $\mathrm{E}_{\mathrm{a}}$ & $\begin{array}{l}1.3 \\
(+/-0.3)\end{array}$ & $\begin{array}{l}1.5 \\
(+/-0.1)\end{array}$ & $\mathrm{eV}$ \\
\hline & & & & \\
\hline
\end{tabular}

The activation energy values for oxygen reduction reaction and the $R_{p}$ values calculated for these cathodes are comparable to the values reported in Chapter 03 for the LSM infiltrated YSZ cathodes. However, the $\mathrm{R}_{\mathrm{s}}$ value reported for sample (ii) is higher than the typical $\mathrm{R}_{\mathrm{S}}$ value at $800{ }^{0} \mathrm{C}$ for $\mathrm{YSZ}\left(\sim 0.7 \mathrm{Ohmcm}^{2}\right)$ which may be due to poor sintering of the Ag current collector on HF etched YSZ surface. This result is surprising since the HF etching should have removed impurities likely to inhibit sintering. This attempt to recreate the infiltration methods reported in the literature [31] did not produce 
a cathode with markedly superior performance (smaller polarization resistance) than the 2-D cathodes formed from solution based LSM cathodes with silver current collector. Kungas et al. [35] have reported a $\mathrm{R}_{\mathrm{p}}$ value $\sim 0.5 \mathrm{Ohm} \mathrm{cm}^{2}$ at $700{ }^{0} \mathrm{C}$ for their LSM infiltrated HF etched YSZ scaffolds. Our HF etched YSZ surfaces showed a roughness to the naked eye. However, we were not able to get high quality SEM images of the HF etched surface (as Kungas et al. [35] have reported) to assure that the HF etching produced a well porous cathode, due to instrument limitations.

\subsection{Summary}

Results for the sintering study of LSM paste cathodes showed $1200{ }^{0} \mathrm{C}$ as the optimum sintering temperature. Deconvolution of impedance data collected for LSM paste cathodes needed several RQ elements to fit the data. The performances of the LSM paste cathodes were almost same with different current collectors.

Solution based LSM cathodes showed very different results compared to the LSM paste cathodes. They yielded very low $\mathrm{R}_{\mathrm{p}}$ values, higher peak frequencies and deconvolution spectra that can be fitted using one or two RQ elements. However, the performance of these solution based cathodes varies with different current collectors, which suggests that the current collector participates in the electrochemical reaction of solution based LSM cathodes. Using the activation energy as an indicator for the dominant electrode material, some of the cells appeared to be controlled by the metal and some by the LSM. In the former case, the impedance behavior of the metal electrode is synergistically improved by the presence of the LSM particles, possibly through inhibition of agglomeration of the metal particles. The solution based LSM cathodes with Ag current collectors (especially the solution based cathode sintered at $1200{ }^{\circ} \mathrm{C}$ ) exhibit less aging than LSM powder based cathodes over a five day experiment.

LSM infiltrated improved YSZ scaffolds with Ag current collectors yielded deconvolution spectra that did not show the presence of marked Gerischer impedance. However, the performance of these cathodes was not substantially superior to the results reported in Chapter 03. 


\subsection{Conclusion}

LSM cathodes are typically developed using pastes prepared from commercial LSM powders that have undergone high temperature sintering steps during the synthesis processes. However, there are no reported attempts to develop LSM cathodes by evaporating a LSM precursor solution on the electrolyte (YSZ) followed by firing at a much lower sintering temperature. In this study, we have prepared solution based LSM cathodes using two different LSM precursor solutions. However, the performance of the solution based LSM cathodes cannot be directly compared with the LSM paste cathodes since their performance is directly dependent on the current collector. At this stage, it is not possible to propose a mechanism for the oxygen reduction reaction on LSM solution based cathodes with Ag current collector since we cannot differentiate whether the LSM or Ag or both LSM and Ag perform as the cathode material. Nevertheless, it would be possible to further improve this Ag-LSM "composite" to be used as a cathode in intermediate temperature solid oxide fuel cells (IT-SOFCs) due to its low polarization and activation energy values, stability over time and the simple method of preparation. Most importantly, since the peak frequencies for impedance data of LSM solution based cathode and LSM paste cathode (with the Ag current collector) are around two orders of magnitude apart, this disparity in frequency provides an opportunity to study the behavior of each electrode separately, without overlapping impedance elements. However, if only the properties of solution based LSM cathodes are needed to be studied further, multiple deposition and sintering steps must be followed in order to develop a relatively thicker electrode which would eliminate the participation of the current collector in oxygen reduction reaction of the solution based LSM cathode.

For the first time, we have carried out deconvolution studies of the impedance data collected for LSM infiltrated YSZ nanofiber cathodes and have shown that in both LSM infiltrated YSZ scaffolds (nanofiber and powder) possibly the same oxygen reduction reaction mechanism takes place. 


\subsection{References}

1. Minh, N.Q., Takahashi T., Science and Technology of Ceramic Fuel Cells, Elsevier science B.V., ISBN 044489568X, 1995

2. Yokokawa H., Tu H., Iwanschitz B., Mai A., Journal of Power Sources, 2008, $182,400-412$

3. Chen X., Aging Effects of the Cathode and Determination of Single Electrode Performance in a Solid Oxide Fuel Cell, Dissertation, West Virginia University, 2013

4. Schichlein H., Muller A., Voigts M., Krugel A., Ivers-Tiffee E., Journal of Applied Electrochemistry, 2002, 32, 875-882

5. Cronin J., Muangnapoh K., Patterson Z., Yakal-Kremski K, Barnett S., Electrochemical Society Transactions, 2011, 35, 2369-2378

6. Abernathy H., Finklea H., Mebane D., Chen X., Gerdes K., Salazar-Villalpando M., Journal of Power Sources, 2012, 216, 11-14

7. Jiang S., Love J., Solid State Ionics, 2001, 138, 183-190

8. Fister T., Fong D., Eastman J., Baldo P., Highland M., Fuoss P., Balasubramaniam K., Meador J., Salvador P., Applied Physics Letters, 2008, 93, 151904-1 - 151904-3

9. Chang K., Ingram B., Balasubramaniam K.,Yildiz B., Hennessy D., Salvador P., Leyarovska N., You H., Materials Research Society Symposium Proceedings, 2009, 1126

10. Caillol N., Pijolat M., Siebert E., Applied Surface Science, 2007, 253, 4641-4648

11. Sasaki K., Wurth J., Gschwend R., Gödickemeier M., Gauckler L., Journal of Electrochemical Society, 1996, 143 (2), 530-543

12. Choi J., Qin W., Liu M, Liu M., Journal of American Ceramic Society, 2011, 94, 3340-3345

13. Zhu X., Ding S., Li Y., Lu Z., Su W., Zhen L., International Journal of Hydrogen Energy, 2013, 38, 5375-5382

14. Bracco G., Holst B., Chapter 1, Surface Science Techniques, Springer Series in Surface Sciences, Vol. 51, 2013, ISBN 978-3-642-34242-4 
15. Skoog D.A., Holler F,J., Crouch S.R., Instrumental Analysis, 2007, Cengage Learning India Private Limited, New Delhi, ISBN 978-81-315-0542-7, 976, 2007

16. Reddy Channu V., Holze R., Walker E., New Journal of Glass and Ceramics, 2013, 3 (1), 29-33

17. Ghosh A, Scripta Materialia, 2005, 52, 1305-1309

18. Cesário M., Macedo D., Oliveira R, Pimentel P., Moreira R., Melo D., Journal of Ceramic Processing Research, 2011, 12 (1), 102-105

19. Sarikaya A., Petrovsky V., Dogan F., ECS transactions., 2012, 45 (1), 25-32

20. Lee S., "SEM images of LSC particles on various substrates", Presentation, National Energy Technology Laboratory, Morgantown, West Virginia, 2014

21. Guillodo M., Vernoux P., Fouletier J., Solid State Ionics, 2000, 127, 99-107

22. Guo Y., Liu Y., Cai R., Chen D., Ran R., Shao Z., International Journal of Hydrogen Energy, 2012, 37(19), 14492-14500

23. Boukamp, B., Bouwmeester H., Solid State Ionics, 2003, 157, 29-33

24. Sarikaya A., Petrovsky V., Dogan F., Journal of Materials Research, 2012, 27 (15), 2024-2029

25. Vladikova D., Stoynov Z., Barbucci A., Viviani M., Carpanese P., Kilner J., Skinner S., Rudkin R., Electrochimica Acta, 2008, 53, 7491-7499

26. Sholklapper T., Radmilovic V., Jacobson C., Visco S., De Jonghe L., Journal of Power Sources, 2008, 175, 206-210

27. Hionic ${ }^{\mathrm{TM}}$ Support Buttons (HIONIC-): http://www.fuelcellmarkets.com/fuel_cell_materials_SOFC_Materials/products_an d_services/3,1,723,17,27892.html (09/05/2014)

28. Hionic Electrolyte Support, MSDS (online), NexTech Materials Ltd., September 10, 2007. http://www.fuelcellmarkets.com/content/images/articles/Hionic.pdf $(09 / 05 / 2014)$

29. Jiang S., Journal of Materials Science, 2008, 43, 6799-6833

30. Siebert E., Hammouche A., Kleitz M, Electrochimica Acta, 1995, 40, 1741-1753

31. Van Herle J., McEvoy A., Thampi K., Electrochimica Acta, 1996, 41(9), 1447-1454

32. Co A., Birss V., Journal of Physical Chemistry B., 2006, 110, 11299-11309

33. Murray E.P., Tsai T., Barnett S.A., Solid State Ionics, 1998, 110, 235-243 
34. Ostergard M., Mogensen M., Electrochimica Acta, 1993, 38(14), 2015-2020

35. Kungas R., Kim J., Vohs J., Gorte R., Journal of American Ceramic Society, 2011, 94, 2220-2224

36. Jensen S., Hauch A., Knibbe R., Jacobsen T., Mogensen M., Journal of the Electrochemical Society, 2013, 160(3), F244-F250

37. Orazem M., Tribollet B., Electrochemical Impedance Spectroscopy, The Electrochemical Society Series, John Wiley \& Sons, 2008 , pp. 252-255

38. Buyukaksoy A., Petrovsky V., Dogan F., Journal of the Electrochemical Society, 2012, 159, B68-B72

39. Chen K., Ai N., Jiang S.P, Electrochemistry Communications, 2012, 19, 119-122 


\section{Chapter 05}

\section{LSM/YSZ Hybrid Cells}

\subsection{Introduction}

One of the major limitations in SOFC characterization studies using impedance spectroscopy is the difficulty to separate processes related to anode and cathode due to their overlapping peak frequencies [1]. As we have discussed in Chapter 04, impedance spectra for powder based LSM cathodes result in peak frequencies in the 1-10 Hz range while the impedance spectra for solution based LSM cathodes (sintered at $800^{\circ} \mathrm{C}$ or $900^{\circ} \mathrm{C}$ ) with $\mathrm{Ag}$ current collectors result in peak frequencies about 2 to 3 orders of magnitudes higher. We took advantage of this property to prepare "LSM/YSZ hybrid cells" in order to isolate and study the powder based LSM cathode and the solution based LSM cathode separately with minimal effects from each other. Figure 5.1 shows an example of a Cole-Cole plot and a Z" (negative out of phase impedance) vs log frequency plot with equivalent circuit fitting (2 RQ elements) of impedance data collected for a LSM/YSZ hybrid cell at $800^{\circ} \mathrm{C}$.
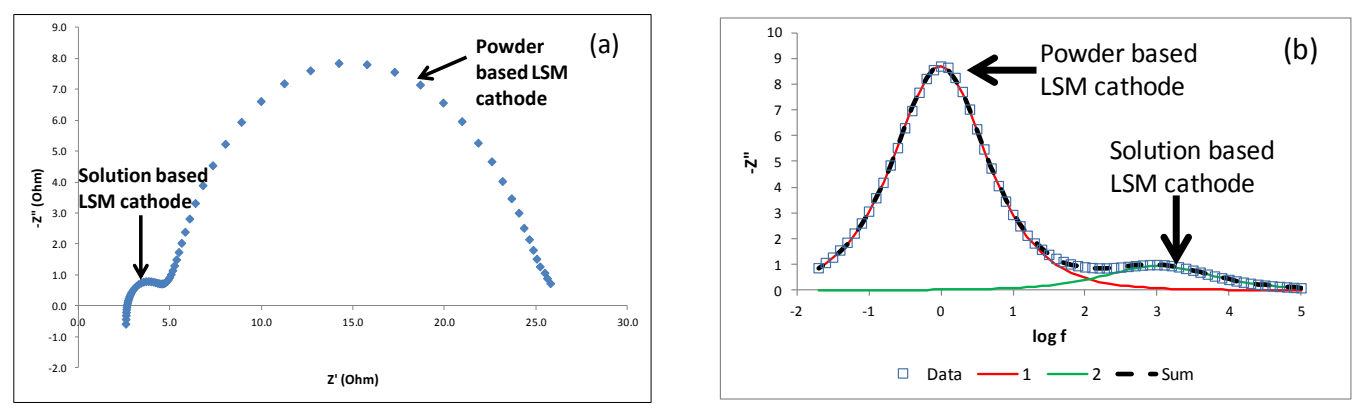

Figure 5.1: Cole-Cole plot (a) and Negative out of phase impedance vs log frequency plot with equivalent circuit fitting (b) for a LSM/YSZ hybrid cell with Ag current collectors at $800{ }^{\circ} \mathrm{C}$.

As discussed in detail in Chapter 04, it is known that the Ag current collector is involved in the oxygen reduction reaction of solution based LSM cathodes, which might result in a complex oxygen reduction reaction mechanism that cannot be explained at this stage. However, since the current collector did not show any effect on powder based LSM 
cathodes, this study would be more beneficial in terms of investigating the oxygen reduction process on a single LSM powder based cathode.

The oxygen reduction reaction mechanism on LSM/YSZ systems has been extensively studied using model cathodes. Since LSM is primarily an electron conductor, one can expect the surface path to be predominant for the oxygen reduction reaction. However, previous work have suggested that both the surface and bulk path simultaneously reduce oxygen on LSM cathodes. Depending on the cathode microstructure (thickness, area, porosity, particle size) and conditions applied $\left(\mathrm{pO}_{2}\right.$, temperature, polarization) either the surface path or the bulk path (Figure 5.2 [4]) would be predominant [2] - [5]. Since most of these studies have been carried out on dense LSM electrodes, the effects of gas diffusion on oxygen reduction mechanism of porous LSM cathodes are overlooked most of the time [4]. Most of the time, porous cathodes are not convenient for comparison studies due to the complexity of microstructure (variations in TPB length, pore size, particle size, surface area etc.) [6] which in turn might result in different rate determining steps. Nevertheless, previous work [6], [7] have reported that the porous LSM cathodes predominantly reduce oxygen via the surface path under cathodic polarization conditions. Siebert et al. [8] had shown that the surface oxygen reduction pathway is favored for LSM cathodes under low anodic or cathodic polarization conditions while Adler's review [3] mentions that the porous LSM cathodes reduce oxygen via the surface pathway near the open circuit voltage (OCV). Brichzin et al. [5] and Fleig et al.'s [9] studies on thin film dense LSM microelectrodes suggest that the bulk path is favored under cathodic polarization conditions while the surface path is favored under anodic polarization conditions for the oxygen reduction reaction due to the changes in oxide ion vacancies of LSM.

In the same way, various elementary steps have been proposed as the rate determining step(s) of the oxygen reduction reaction on LSM. Gas phase oxygen diffusion, surface diffusion of adsorbed oxygen and oxygen incorporation to YSZ at TPB are some of them [5]- [7], [9]. 


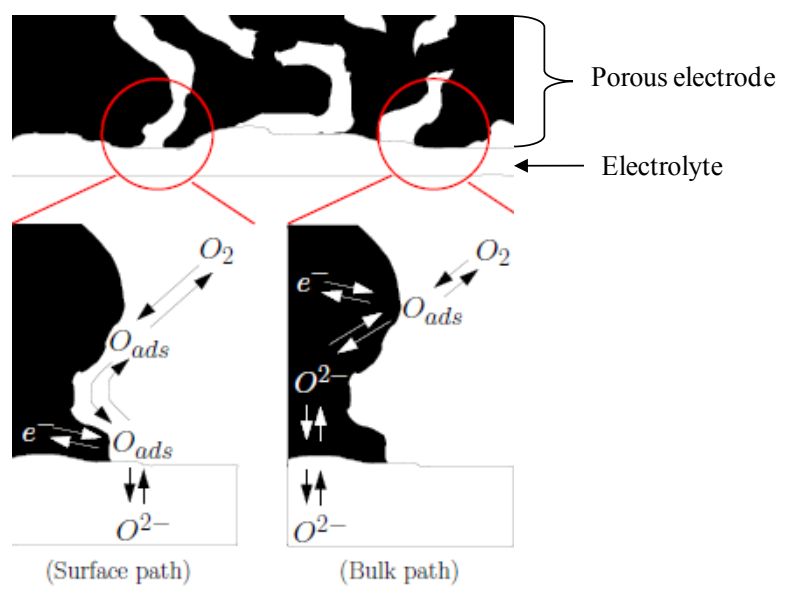

Figure 5.2: Surface and bulk paths for oxygen reduction reaction on a porous cathode [4].

\subsection{Experimental}

As mentioned in Section 4.2, a powder based LSM cathode was painted on one side of the YSZ electrolyte (tape was used to define the area and the thickness) and sintered at $1200{ }^{\circ} \mathrm{C}$ for 1 hour. On the other side of the electrolyte, a solution (organic) based LSM cathode was prepared (as mentioned in Section 4.3) and sintered at $900{ }^{\circ} \mathrm{C}$ for 1 hour to prepare the LSM/YSZ "hybrid" cell. Two different hybrid cells (cell A and cell B) were prepared using the same procedure. Then, these cells were electrochemically characterized using $\mathrm{Ag}$ current collectors and $\mathrm{Ag}$ wires. In order to increase the porosity of the $\mathrm{Ag}$ current collector, a very thin layer of the diluted commercial silver paste was used.

Both Cell A and Cell B were first characterized at $800{ }^{\circ} \mathrm{C}, 750{ }^{\circ} \mathrm{C}$ and $700{ }^{\circ} \mathrm{C}$ at the open circuit voltage (OCV) using impedance spectroscopy. Then, the cells were brought back to $800{ }^{\circ} \mathrm{C}$ and characterized at OCV. After that, Cell A was characterized under applied DC voltages and Cell B was characterized under applied DC currents. The LEVM/LEVMW program was used to fit the collected impedance data to equivalent circuits.

\subsubsection{Temperature Study}

\section{Experimental}

As mentioned above, LSM/YSZ hybrid cells were prepared and both Cells A and B were electrochemically characterized at $800{ }^{0} \mathrm{C}, 750{ }^{\circ} \mathrm{C}$ and $700{ }^{\circ} \mathrm{C}$ at the OCV. For the 
temperature study of both cells, impedance analysis was carried out by applying an AC voltage and recording the $\mathrm{AC}$ current. Then, the impedance data were fitted using a simple LR (RQ)(RQ) equivalent circuit.

\section{$\underline{\text { Results and Discussion }}$}

As shown in Figure 5.1, the RQ1 equivalent circuit element is assigned to the powder based LSM cathode and the RQ2 element is assigned to the solution based LSM cathode. As shown in Table 5.1, R2, Q1 and n1 are the parameters associated with the powder based LSM cathode while R3, Q2 and n2 are the parameters associated with the solution based LSM cathode. R1 is the series resistance of the cell.

Table 5.1: Summary of results obtained for the temperature study of LSM/YSZ hybrid cells.

\begin{tabular}{|c|c|c|c|c|c|c|c|c|}
\hline & $\begin{array}{l}\text { Temperature } \\
\left.\text { ( }{ }^{0} \mathrm{C}\right)\end{array}$ & $\begin{array}{c}\text { R1 } \\
\left(\text { Ohmcm }^{2}\right)\end{array}$ & $\begin{array}{c}\text { R2 } \\
\left(\mathrm{Ohmcm}^{2}\right)\end{array}$ & Q1 & n1 & $\begin{array}{c}\text { R3 } \\
\left(\mathrm{Ohmcm}^{2}\right)\end{array}$ & Q2 & $\mathrm{n} 2$ \\
\hline \multirow{4}{*}{$\stackrel{\Xi}{\bar{\theta}}$} & 800 & 0.73 & 5.95 & $\begin{array}{c}3.38 \mathrm{E} \\
-02\end{array}$ & 0.831 & 0.68 & $\begin{array}{l}2.29 \\
\text { E-03 }\end{array}$ & 0.726 \\
\hline & 750 & 1.05 & 13.00 & $\begin{array}{c}3.14 \mathrm{E} \\
-02\end{array}$ & 0.823 & 1.45 & $\begin{array}{l}1.43 \\
\text { E-03 }\end{array}$ & 0.751 \\
\hline & 700 & 1.62 & 26.96 & $\begin{array}{c}2.91 \mathrm{E} \\
-02\end{array}$ & 0.818 & 2.65 & $\begin{array}{l}1.03 \\
\text { E-03 }\end{array}$ & 0.762 \\
\hline & $\begin{array}{c}\text { Activation } \\
\text { Energy }(e V)\end{array}$ & $\begin{array}{c}0.7 \\
(+/-0.0) \\
\end{array}$ & $\begin{array}{c}1.4 \\
(+/-0.1) \\
\end{array}$ & & & $\begin{array}{c}1.2 \\
(+/-0.1)\end{array}$ & & \\
\hline \multirow{4}{*}{ 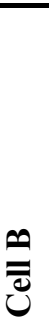 } & 800 & 0.69 & 6.39 & $\begin{array}{c}1.01 \mathrm{E} \\
-02\end{array}$ & 0.727 & 0.98 & $\begin{array}{l}5.94 \\
\text { E-04 }\end{array}$ & 0.826 \\
\hline & 750 & 0.91 & 15.90 & $\begin{array}{c}1.01 \mathrm{E} \\
-02\end{array}$ & 0.717 & 2.90 & $\begin{array}{l}6.20 \\
\text { E-04 }\end{array}$ & 0.792 \\
\hline & 700 & 1.35 & 37.63 & $\begin{array}{c}9.41 \mathrm{E} \\
-03\end{array}$ & 0.716 & 6.68 & $\begin{array}{l}5.77 \\
\text { E-04 }\end{array}$ & 0.774 \\
\hline & $\begin{array}{c}\text { Activation } \\
\text { Energy }(e V)\end{array}$ & $\begin{array}{c}0.6 \\
(+/-0.0)\end{array}$ & $\begin{array}{c}1.6 \\
(+/-0.1)\end{array}$ & & & $\begin{array}{c}1.7 \\
(+/-0.2)\end{array}$ & & \\
\hline
\end{tabular}

The activation energy values associated with $\mathrm{R} 2$ range from $1.4(+/-0.1)$ to $1.6(+/-0.1)$ for Cells $\mathrm{A}$ and $\mathrm{B}$, which agree with the activation energy for the oxygen reduction reaction on a typical LSM cathode [1]. As shown in Table 4.3, the organic solution based LSM cathode sintered at $900{ }^{0} \mathrm{C}$ usually shows activation energy around $1.30(+/-0.14)$ for the oxygen reduction reaction (Table 4.3), which agrees with Cell A's $E_{a}$ calculated for R3. But, for Cell $\mathrm{B}$ this value is relatively high. "Q" is the constant phase element (CPE) and " $\mathrm{n}$ " is the 
exponent associated with "Q". Capacitance (C) can be calculated using equation 5.1 [10] and it provides information about the degree of involvement of a material's surface, interfaces and bulk in the oxygen reduction reaction reaction [3]. According to the results shown in Table 5.1, both Q1 and n1 show a slight variation with the temperature.

$$
\mathrm{C}=\left(\mathrm{R}^{1-\mathrm{n}} \mathrm{Q}\right)^{1 / \mathrm{n}}
$$

\subsubsection{LSM/YSZ Hybrid Cell Characterization under Polarization}

\section{Experimental}

Following the temperature study (Section 5.2.1), one LSM/YSZ hybrid cell (Cell A) was characterized under applied DC voltages and the other LSM/YSZ hybrid cell (Cell B) was characterized under applied DC currents using the experimental protocol shown below in Table 5.2. Two impedance spectra were recorded one after the other at each condition to check the drifting of the data with time and for noise cancellation through data averaging. However, since noise did not significantly affect the collected data in this system, the second impedance spectrum collected at each condition was used for the analysis. The powder based LSM cathode was used as the working electrode. Collected data was fitted into a $\mathrm{LR}(\mathrm{RQ}) 2$ equivalent circuit using LEVM/LEVMW software and the resistances associated with each LSM cathode was calculated at each condition.

Table 5.2: Experimental protocol used for impedance analysis of LSM/YSZ hybrid cells under applied DC voltages (Cell A) and DC currents (Cell B).

\begin{tabular}{|c|c|c|}
\hline & Cell A & Cell B \\
\hline 1) & 800 deg EIS OCV2 & $800 \mathrm{deg}$ EIS OCV2 \\
\hline 2) & Potentiostatic $20 \mathrm{~min}, 0.01 \mathrm{~V}$ & Galvanostatic $5 \mathrm{~s}, 0.00 \mathrm{~mA}$ \\
\hline 3) & $800 \mathrm{deg}$ EIS $0.01 \mathrm{~V}$ & $800 \mathrm{deg}$ EIS $0.00 \mathrm{~mA}$ \\
\hline 4) & Potentiostatic $20 \mathrm{~min}, 0.02 \mathrm{~V}$ & Galvanostatic $15 \mathrm{~min}, 0.25 \mathrm{~mA}$ \\
\hline 5) & $800 \mathrm{deg}$ EIS $0.02 \mathrm{~V}$ & $800 \mathrm{deg}$ EIS $0.25 \mathrm{~mA}$ \\
\hline 6) & Potentiostatic $15 \mathrm{~min}, 0.03 \mathrm{~V}$ & Galvanostatic $15 \mathrm{~min}, 0.45 \mathrm{~mA}$ \\
\hline 7) & $800 \mathrm{deg}$ EIS $0.03 \mathrm{~V}$ & $800 \mathrm{deg}$ EIS $0.45 \mathrm{~mA}$ \\
\hline 8) & Potentiostatic $15 \mathrm{~min}, 0.04 \mathrm{~V}$ & Galvanostatic $15 \mathrm{~min}, 0.60 \mathrm{~mA}$ \\
\hline 9) & $800 \mathrm{deg}$ EIS $0.04 \mathrm{~V}$ & $800 \mathrm{deg}$ EIS $0.60 \mathrm{~mA}$ \\
\hline 10) & Potentiostatic $15 \mathrm{~min}, 0.05 \mathrm{~V}$ & Galvanostatic $15 \mathrm{~min}, 0.80 \mathrm{~mA}$ \\
\hline 11) & $800 \mathrm{deg}$ EIS $0.05 \mathrm{~V}$ & $800 \mathrm{deg}$ EIS $0.80 \mathrm{~mA}$ \\
\hline
\end{tabular}




\begin{tabular}{|c|c|c|}
\hline 12) & $800 \mathrm{deg}$ EIS OCV3 & 800 deg EIS OCV3 \\
\hline 13) & Potentiostatic $15 \mathrm{~min}, 0.06 \mathrm{~V}$ & Galvanostatic $15 \mathrm{~min}, 1.0 \mathrm{~mA}$ \\
\hline 14) & 800 deg EIS $0.06 \mathrm{~V}$ & $800 \mathrm{deg}$ EIS $1.0 \mathrm{~mA}$ \\
\hline 15) & Potentiostatic $15 \mathrm{~min}, 0.07 \mathrm{~V}$ & Galvanostatic $15 \mathrm{~min}, 1.2 \mathrm{~mA}$ \\
\hline 16) & $800 \mathrm{deg}$ EIS $0.07 \mathrm{~V}$ & $800 \mathrm{deg}$ EIS $1.2 \mathrm{~mA}$ \\
\hline 17) & 800 deg EIS OCV4 & Galvanostatic $15 \mathrm{~min}, 1.5 \mathrm{~mA}$ \\
\hline 18) & Potentiostatic $15 \mathrm{~min},-0.01 \mathrm{~V}$ & $800 \mathrm{deg}$ EIS $1.5 \mathrm{~mA}$ \\
\hline 19) & 800 deg EIS $-0.01 \mathrm{~V}$ & Galvanostatic $15 \mathrm{~min}, 1.8 \mathrm{~mA}$ \\
\hline 20) & Potentiostatic $15 \mathrm{~min},-0.02 \mathrm{~V}$ & $800 \mathrm{deg}$ EIS $1.8 \mathrm{~mA}$ \\
\hline 21) & 800 deg EIS $-0.02 \mathrm{~V}$ & Galvanostatic $15 \mathrm{~min}, 2.1 \mathrm{~mA}$ \\
\hline 22) & Potentiostatic $15 \mathrm{~min},-0.03 \mathrm{~V}$ & $800 \mathrm{deg}$ EIS $2.1 \mathrm{~mA}$ \\
\hline 23) & 800 deg EIS $-0.03 \mathrm{~V}$ & Galvanostatic $15 \mathrm{~min}, 2.5 \mathrm{~mA}$ \\
\hline 24) & Potentiostatic $15 \mathrm{~min},-0.04 \mathrm{~V}$ & $800 \mathrm{deg}$ EIS $2.5 \mathrm{~mA}$ \\
\hline 25) & 800 deg EIS $-0.04 \mathrm{~V}$ & 800 deg EIS OCV4 \\
\hline 26) & 800 deg EIS OCV5 & Galvanostatic $15 \mathrm{~min},-0.25 \mathrm{~mA}$ \\
\hline 27) & Potentiostatic $15 \mathrm{~min},-0.05 \mathrm{~V}$ & 800 deg EIS $-0.25 \mathrm{~mA}$ \\
\hline 28) & 800 deg EIS $-0.05 \mathrm{~V}$ & Galvanostatic $15 \mathrm{~min},-0.5 \mathrm{~mA}$ \\
\hline 29) & Potentiostatic $15 \mathrm{~min},-0.06 \mathrm{~V}$ & $800 \mathrm{deg}$ EIS $-0.5 \mathrm{~mA}$ \\
\hline 30$)$ & 800 deg EIS $-0.06 \mathrm{~V}$ & Galvanostatic $15 \mathrm{~min},-0.75 \mathrm{~mA}$ \\
\hline 31) & Potentiostatic $15 \mathrm{~min},-0.07 \mathrm{~V}$ & 800 deg EIS $-0.75 \mathrm{~mA}$ \\
\hline 32) & 800 deg EIS $-0.07 \mathrm{~V}$ & Galvanostatic $15 \mathrm{~min},-1.0 \mathrm{~mA}$ \\
\hline 33) & Potentiostatic $15 \mathrm{~min},-0.08 \mathrm{~V}$ & $800 \mathrm{deg}$ EIS $-1.0 \mathrm{~mA}$ \\
\hline 34) & 800 deg EIS $-0.08 \mathrm{~V}$ & Galvanostatic $15 \mathrm{~min},-1.3 \mathrm{~mA}$ \\
\hline 35$)$ & Potentiostatic $15 \mathrm{~min},-0.09 \mathrm{~V}$ & $800 \mathrm{deg}$ EIS $-1.3 \mathrm{~mA}$ \\
\hline 36) & 800 deg EIS $-0.09 \mathrm{~V}$ & 800 deg EIS OCV5 \\
\hline 37) & 800 deg EIS OCV6 & Galvanostatic $15 \mathrm{~min},-1.6 \mathrm{~mA}$ \\
\hline 38$)$ & & $800 \mathrm{deg}$ EIS $-1.6 \mathrm{~mA}$ \\
\hline 39) & & Galvanostatic $15 \mathrm{~min},-2.0 \mathrm{~mA}$ \\
\hline 40) & & $800 \mathrm{deg}$ EIS $-2.0 \mathrm{~mA}$ \\
\hline 41) & & Galvanostatic $15 \mathrm{~min},-2.5 \mathrm{~mA}$ \\
\hline 42) & & $800 \mathrm{deg}$ EIS $-2.5 \mathrm{~mA}$ \\
\hline 43) & & Galvanostatic $15 \mathrm{~min},-3.0 \mathrm{~mA}$ \\
\hline 44) & & $800 \mathrm{deg}$ EIS $-3.0 \mathrm{~mA}$ \\
\hline 45) & & Galvanostatic $15 \mathrm{~min},-3.6 \mathrm{~mA}$ \\
\hline 46) & & $800 \mathrm{deg}$ EIS $-3.6 \mathrm{~mA}$ \\
\hline 47) & & 800 deg EIS OCV6 \\
\hline
\end{tabular}

\section{$\underline{\text { Results and Discussion - Anodic Polarization }}$}

When a positive DC voltage/current is applied to the hybrid cell, the powder based LSM electrode which is used as the working electrode acts as the anode $\left(2 \mathrm{O}^{2-} \rightarrow \mathrm{O}_{2}(\mathrm{~g})+4 \mathrm{e}^{-}\right)$ while the solution based LSM electrode acts as the cathode $\left(\mathrm{O}_{2(\mathrm{~g})}+4 \mathrm{e}^{-} \rightarrow 2 \mathrm{O}^{2-}\right)$. When a negative DC voltage/current is applied to the hybrid cell, the reverse reactions take place 
making the powder based LSM electrode the cathode $\left(\mathrm{O}_{2(\mathrm{~g})}+4 \mathrm{e}^{-} \rightarrow 2 \mathrm{O}^{2-}\right)$ and the solution based LSM electrode the anode $\left(2 \mathrm{O}^{2-} \rightarrow \mathrm{O}_{2(\mathrm{~g})}+4 \mathrm{e}^{-}\right)$.

The impedance data collected for the anodically polarized hybrid cells initially (at low positive voltages/currents) agreed with the LR(RQ)2 equivalent circuit. However, with increasing anodic polarization, there appeared to be another low frequency arc (for both Cells A and B) which was included in the equivalent circuit as a parallel RC element (Figure 5.3). The appearance of this low frequency arc limited the deconvolution of impedance data at higher anodic polarization conditions and also limited the ability to deduce an accurate total resistance $\left(R_{t}\right)$ value which would be consistent with the $R_{t}$ value calculated from the potentiostatic/galvanostatic experiment (Figure 5.5 (b) and (h)).

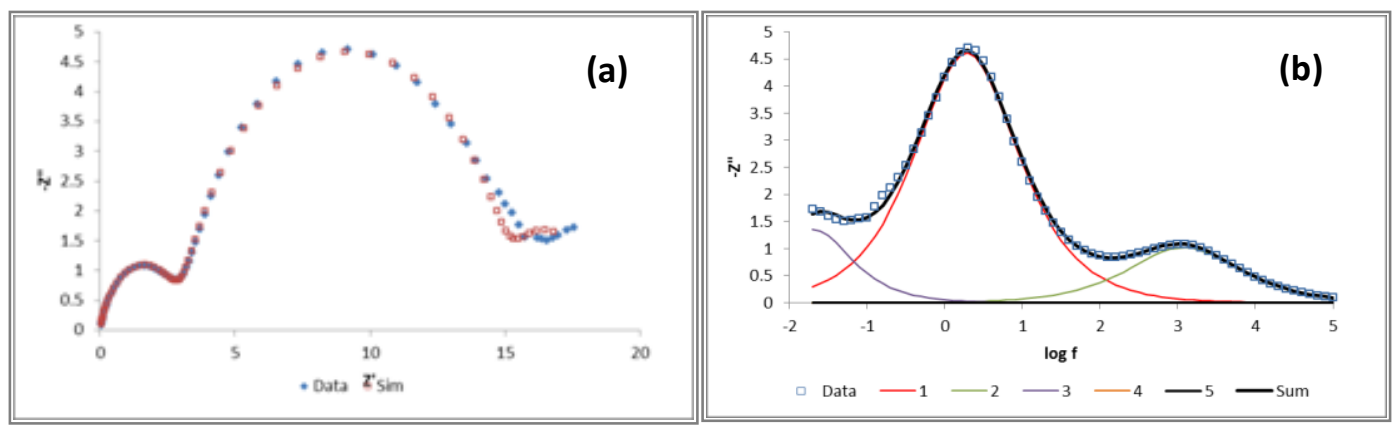

Figure 5.3: Cole-Cole plot (a) and Negative out of phase impedance vs log frequency plot with equivalent circuit fitting (b) for a LSM/YSZ hybrid cell under $70 \mathrm{mV}$ applied current at $800{ }^{\circ} \mathrm{C}$. The solid lines in (b) show the contributions of the three elements (RQ1, RQ2 \& RC) in the equivalent circuit.

In order to investigate the origin of this low frequency arc, the polarization experiment was repeated with a powder based LSM/YSZ (prepared as mentioned in Section 4.2) and a solution based LSM/YSZ (prepared as mentioned in Section 4.3) symmetrical cells to obtain the results shown in Figure 5.4.

From the observations in Figure 5.4, it is evident that the low frequency arc appears only on the powder based LSM cathodes at anodic polarization conditions. Hence, we can confirm that the low frequency arc observed in LSM/YSZ hybrid cells is also associated with the powder based LSM cathode but not with the solution based LSM cathode. 

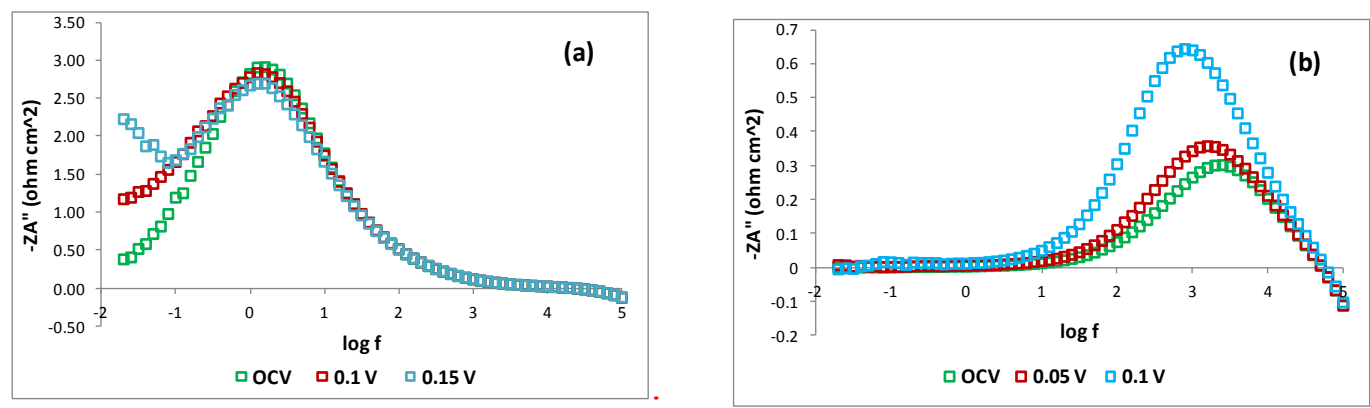

Figure 5.4: Negative out of phase impedance vs log frequency plots for different applied positive voltages at $800{ }^{0} \mathrm{C}$ for (a) powder based LSM/YSZ symmetrical cell and (b) solution based LSM/YSZ symmetrical cell.
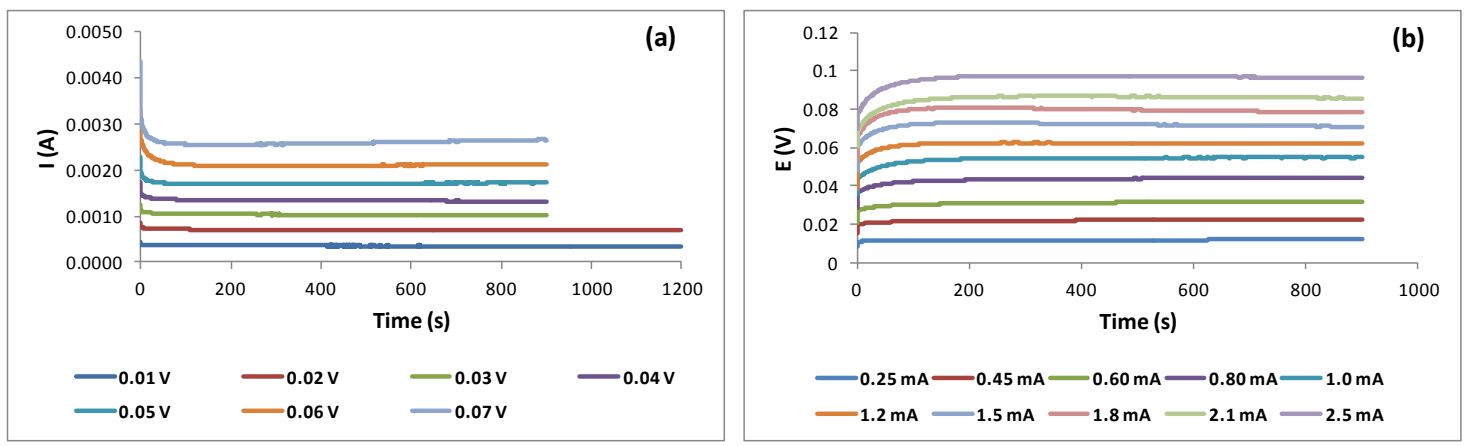

Figure 5.5: (a) Current vs. time plots for Cell A (potentiostatic experiment). (b) Potential vs. time plots for Cell B (galvanostatic experiment).

Figure 5.5 presents the results obtained for potentiostatic (Cell A) and galvanostatic (Cell B) experiments for anodic polarization. After 15 minutes the current/voltage becomes almost constant.Total resistance for Cell $\mathrm{A}=$ applied voltage/ final current and the total resistance for Cell $\mathrm{B}=$ final voltage/ applied current.
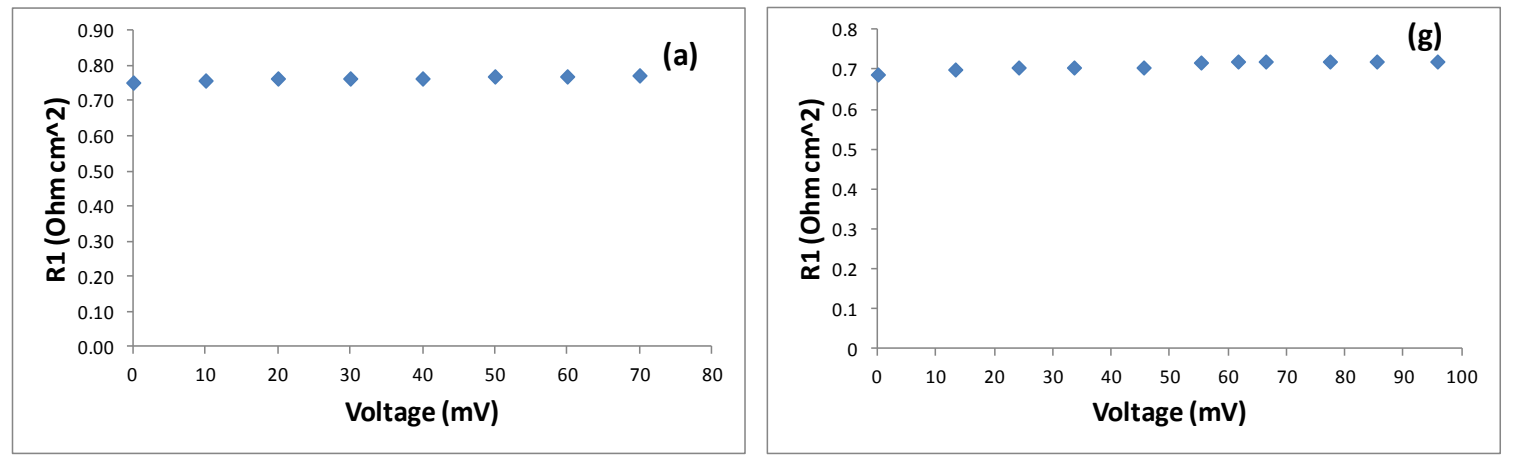

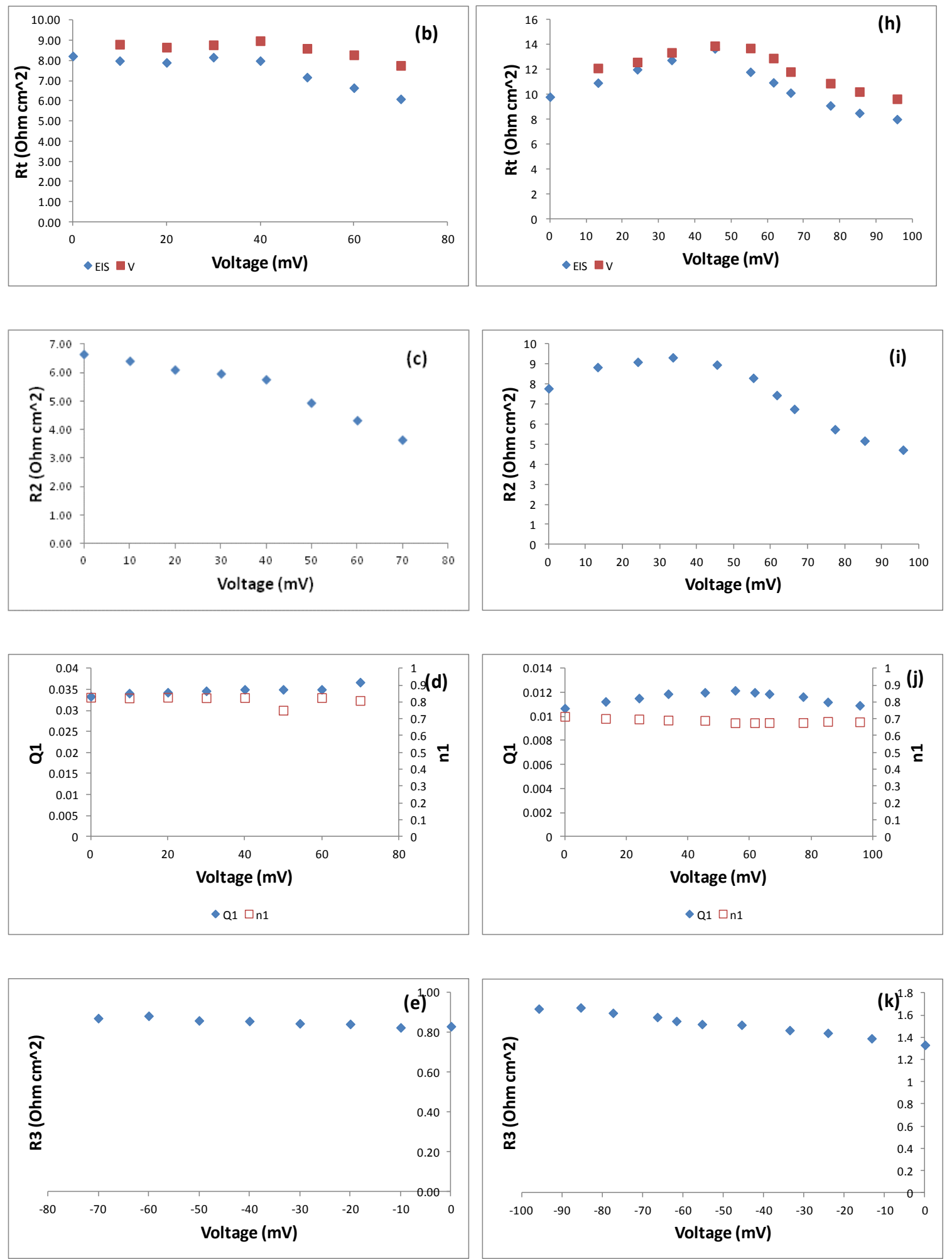

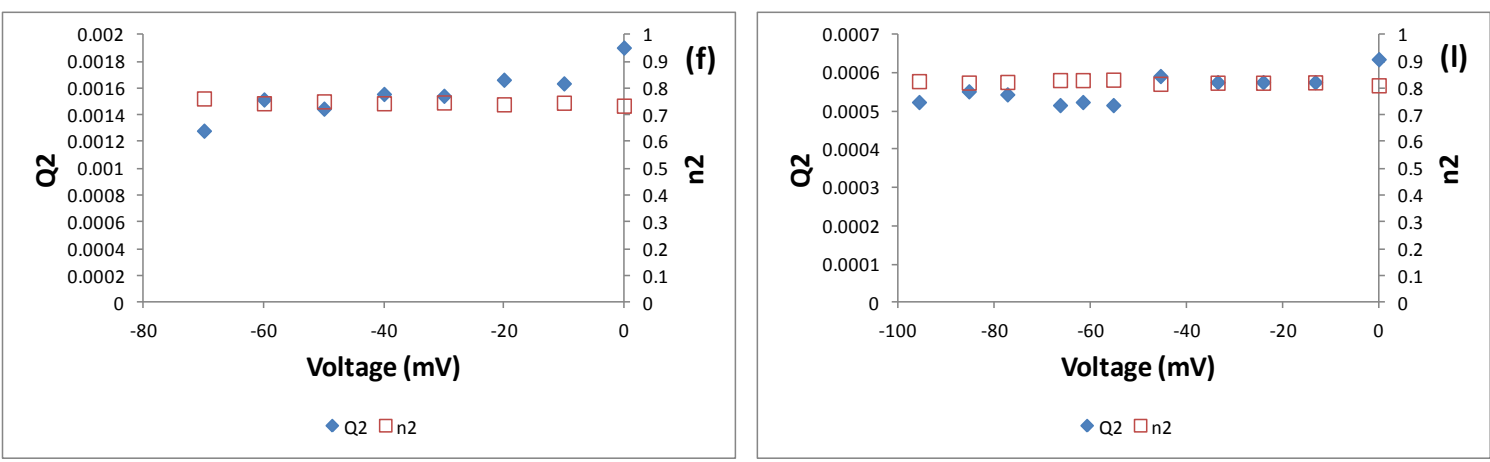

Figure 5.6: Fitting parameters of equivalent circuit elements used for impedance data collected for Cell A ((a)-(f)) and Cell B ((g)-(l)) under anodic polarization (LSM paste electrode anode, LSM solution electrode cathode) at $800{ }^{\circ} \mathrm{C}$. Note the sign change on the voltage axes for R3 and Q2.

Nearly constant series resistance for Cells A and B (Figure 5.6 (a) and (g)) show that delamination of electrodes or current collectors did not occur with applied anodic voltages. The total resistance (Rt) of Cell A (Figure 5.6 (b)) initially stays almost constant but gradually decreases after $\sim 40 \mathrm{mV}$ while the total resistance of Cell B (Figure $5.6(\mathrm{~h})$ ) initially increases slightly but rapidly decreases after $\sim 40 \mathrm{mV}$. Under these conditions, the Rt calculated from the impedance spectroscopy (blue diamonds) is always lower than the Rt calculated from the potentiostatic/galvanostatic experiment (Figure 5.5) (red squares), presumably due to the appearance of the low frequency arc. The added RC element used for Cells $\mathrm{A}$ and $\mathrm{B}$ equivalent circuits does not account for the discrepancy between Rt values, suggesting that this arc is not well described by the RC equivalent circuit element. The polarization resistance associated with the powder based LSM cathode (R2) of Cell A shows a gradual decrease followed by a rapid decrease (Figure 5.6 (c)) while the R2 of Cell B shows a slight increase followed by a rapid decrease and then a gradual decrease. Variations of the area normalized constant phase element (Q1) value associated with Cells A and B (Figures $5.6(\mathrm{~d})$ and (j)) show that it is not independent of the polarization but that the changes with applied voltage are small. Similarly, the changes in the exponent (n) are small.

Mogensen and Ostergard [11] have reported $10^{-5} \mathrm{Fcm}^{-2}(\mathrm{n}=0.9)$ as the $\mathrm{Q}$ value for the LSM-YSZ interface and $10^{-3} \mathrm{Fcm}^{-2}(\mathrm{n}=0.6)$ as the $\mathrm{Q}$ value associated with the adsorptive dissociation of oxygen on LSM. They have also reported that both the capacitances and 
exponent values are independent of the applied overpotential [11]. Fleig et al. [12] have measured $10^{-3} \mathrm{Fcm}^{-2}$ as the capacitance value associated with the oxygen exchange at the LSM cathode surface and $10^{-5} \mathrm{Fcm}^{-2}(\mathrm{n}=0.8)$ as the Q value between the LSM-YSZ interface. Chen et al. [7] reports a $Q$ value of $5 \times 10^{-3} \mathrm{Fcm}^{-2}$ for surface diffusion of adsorbed oxygen species on LSM while Van Herle et al. [13] have reported a capacitance value of $2 \times 10^{-3} \mathrm{Fcm}^{-2}$ associated with the adsorbed oxygen layer on LSM. Furthermore, Jiang et al. [14] have attributed their observed $0.018-0.032 \mathrm{Fcm}^{-2}$ capacitance values to surface adsorption and diffusion process of oxygen. Since the value of Q1 for both Cells A and B range from 0.01 to $0.04 \mathrm{Fcm}^{-2}$ ( $\mathrm{C}$ values calculated using the equation given above range from $\sim 7 \times 10^{-3} \mathrm{Fcm}^{-2}$ to $\sim 7 \times 10^{-4} \mathrm{Fcm}^{-2}$ ), we can suggest that Q1 is either associated with the capacitance at the gas phase-electrode interface or the process of surface adsorption and diffusion of oxygen. Also, any mechanism would have to account for the very weak dependence of the $\mathrm{Q}$ and $\mathrm{n}$ values with respect to the applied voltage.

The activation energy associated with R2 (at OCV) range from $1.4(+/-0.1) \mathrm{eV}$ to $1.6(+/-$ $0.1) \mathrm{eV}$ which is comparable to previously reported $E_{a}$ values associated with surface diffusion of adsorbed oxygen (1.3 eV- $1.6 \mathrm{eV}$ ) [6], [7] and oxygen adsorption and surface diffusion $(1.49 \mathrm{eV}-2.0 \mathrm{eV})$ [9], [10] processes.

When the powder based LSM cathode is under anodic bias, oxygen gas is produced from the $2 \mathrm{O}^{2-} \rightarrow \mathrm{O}_{2(\mathrm{~g})}+4 \mathrm{e}^{-}$reaction. Since the arc only appears under anodic current flow through the LSM paste electrode, we speculate that there is a mass transfer limitation from the points where the oxygen molecule is generated to the outer surface of the electrode. There is no low frequency arc associated with the diffusion of oxygen molecules to the reaction sites under cathodic current flow.

Researchers have reported LSM cathode deactivation (increased $R_{p}$ ) with anodic polarization mainly due to surface deactivation resulting from cation segregation and reduced oxide ion vacancies [16] - [18]. However, several other studies [5], [9], [18], [19] have shown that the anodic polarization results in cathode activation (decreased $\mathrm{R}_{\mathrm{p}}$ ) due to internal cracking of the cathode which results in higher TPB length (and also increased surface area for oxygen adsorption). la'O et al. [19] have observed on thin dense LSM 
films that the magnitude of cathode activation is very high in comparison to the amount of TPB length increased due to electrode cracking with anodic polarization. The cracking is caused by generation of gas bubbles at the LSM/YSZ interface with high gas pressure. From the Nernst equation, one can demonstrate that an overpotential of $+60 \mathrm{mV}$ (at $800^{\circ} \mathrm{C}$ ) can generate an $\mathrm{O}_{2}$ gas pressure $\sim 13$ times higher than the atmospheric $\mathrm{O}_{2}$ partial pressure $(0.2 \mathrm{~atm})$. Furthermore, the authors suggest that the rate limiting step of their oxygen reduction reaction does not occur at the TPB but rather on the surface of the LSM cathode, which means that the rate-limiting step is the oxygen adsorption and the surface diffusion on LSM [19]. Furthermore, la'O et al.'s [19] Auger Electron Spectroscopy (AES) studies on anodic polarized LSM cathode surfaces did not provide any evidence for cation migration. Brichzin et al. [5] have reported that the surface path for oxygen reduction reaction is more favored under anodic bias conditions on dense microdot LSM films. They also observed extrusions in the LSM cathodes after large anodic polarization and reported that high currents were correlated with these extrusions, during their I-V studies. Previous studies [5], [9], [18], [19] suggest that the stress related to high local $\mathrm{pO}_{2}$ inside the cathode (due to oxygen generation under anodic bias) results in these extrusions or cracking inside the cathode. Based on these, we hypothesize that the same "cracking" phenomenon might have occurred in our porous LSM paste electrodes (under anodic polarization) which increased the surface area for "oxygen desorption and surface diffusion" reaction which in turn decreases the polarization and total resistance as observed. Such a physical effect would cause changes in the polarization resistance at zero current (open circuit) after sufficient exposure of the LSM electrode to anodic current. As noted above, the resistance variation we observed (Figure 5.7 (a) and (b) for Cell A and B respectively) for the low frequency (gas diffusion) arc (R4) appears to be associated with this phenomenon.
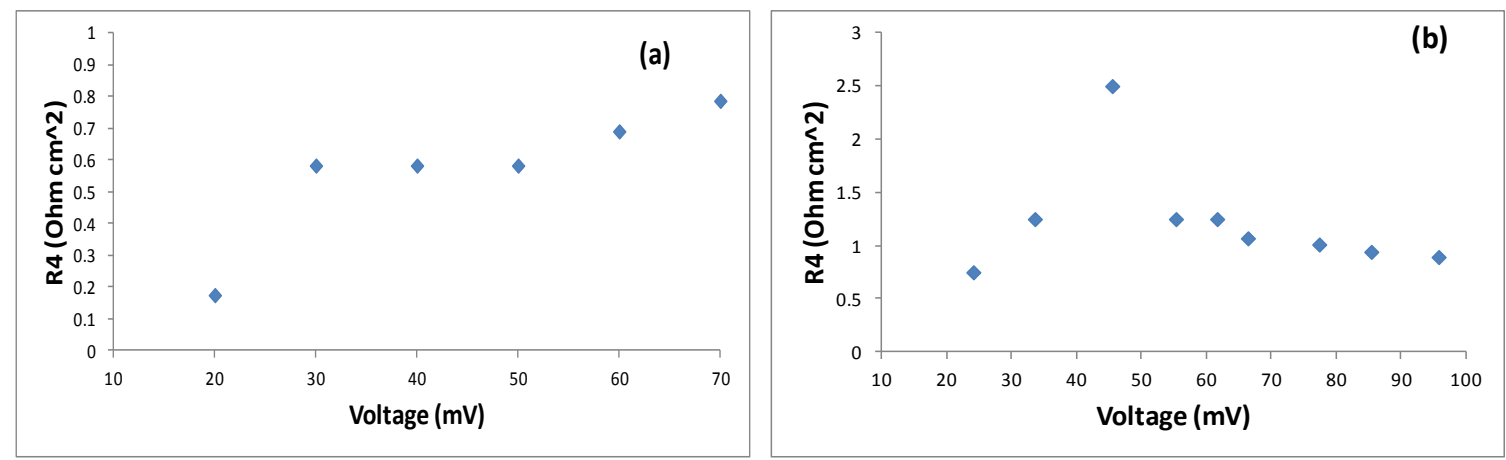
Figure 5.7: Variation of resistance (R4) associated with low frequency (gas diffusion arc) with applied voltage for Cell A (a) and Cell B (b). The values are based on an assumed RC equivalent circuit for the gas diffusion process.

According to Figure 5.7, the resistance for the oxygen gas diffusion inside the cathode appears initially due to limited porosity but stays almost constant at high anodic voltages. Given the uncertainty in the R4 values, interpretation of the trend is subject to considerable uncertainty. The plots suggest that with relatively low voltages, there is sufficient porosity inside the cathode for oxygen gas diffusion to yield a nearly constant diffusion resistance.

Summary for the LSM paste electrode:

- The $\mathrm{E}_{\mathrm{a}}$ associated with R2 (at OCV) suggests that the "surface diffusion of adsorbed oxygen" or "oxygen adsorption and surface diffusion" reaction are associated with the rate limiting step.

- Values of Q1 compare reasonably well with the capacitance values for surface adsorption and diffusion for the gas-electrode interface

- The appearance of low frequency arc is assigned to the gas phase oxygen diffusion from the reaction sites to the bulk

- Decreasing resistances (R2 and Rt) and variations of R4 with increasing anodic polarization may occur due to increased surface area due to the internal cracking of LSM cathode during $\mathrm{O}_{2}$ generation.

\section{$\underline{\text { Results and Discussion - Cathodic Polarization }}$}
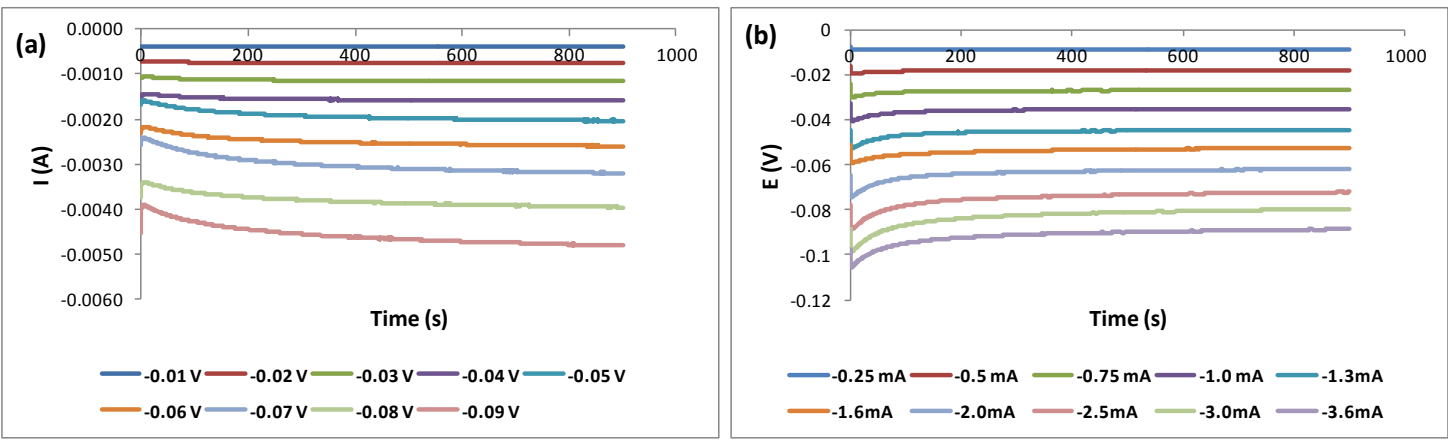

Figure 5.8: (a) Current vs. time plots for Cell A (potentiostatic experiment). (b) Potential vs. time plots for Cell B (galvanostatic experiment). 
Figure 5.8 presents the results obtained for potentiostatic (Cell A) and galvanostatic (Cell B) experiments with cathodic polarization. After 15 minutes the current/voltage becomes almost constant. Total resistance for Cell $\mathrm{A}=$ applied voltage/ final current and the total resistance for Cell B = final voltage/ applied current.

LSM cathode activation (decreased polarization resistance) upon cathodic polarization is a well-known phenomenon [17], [18], [20]. Cation desegregation which removes surface passivating phases such as $\mathrm{SrO}$ or $\mathrm{La}_{2} \mathrm{O}_{3}$, generation of oxygen vacancies due to partial reduction of manganese ions and microstructural evolution are some of the reported reasons for the activation process. Each of these possible mechanisms enhances the oxygen reduction reaction and decreases the polarization resistance under cathodic bias [17], [18], [20].
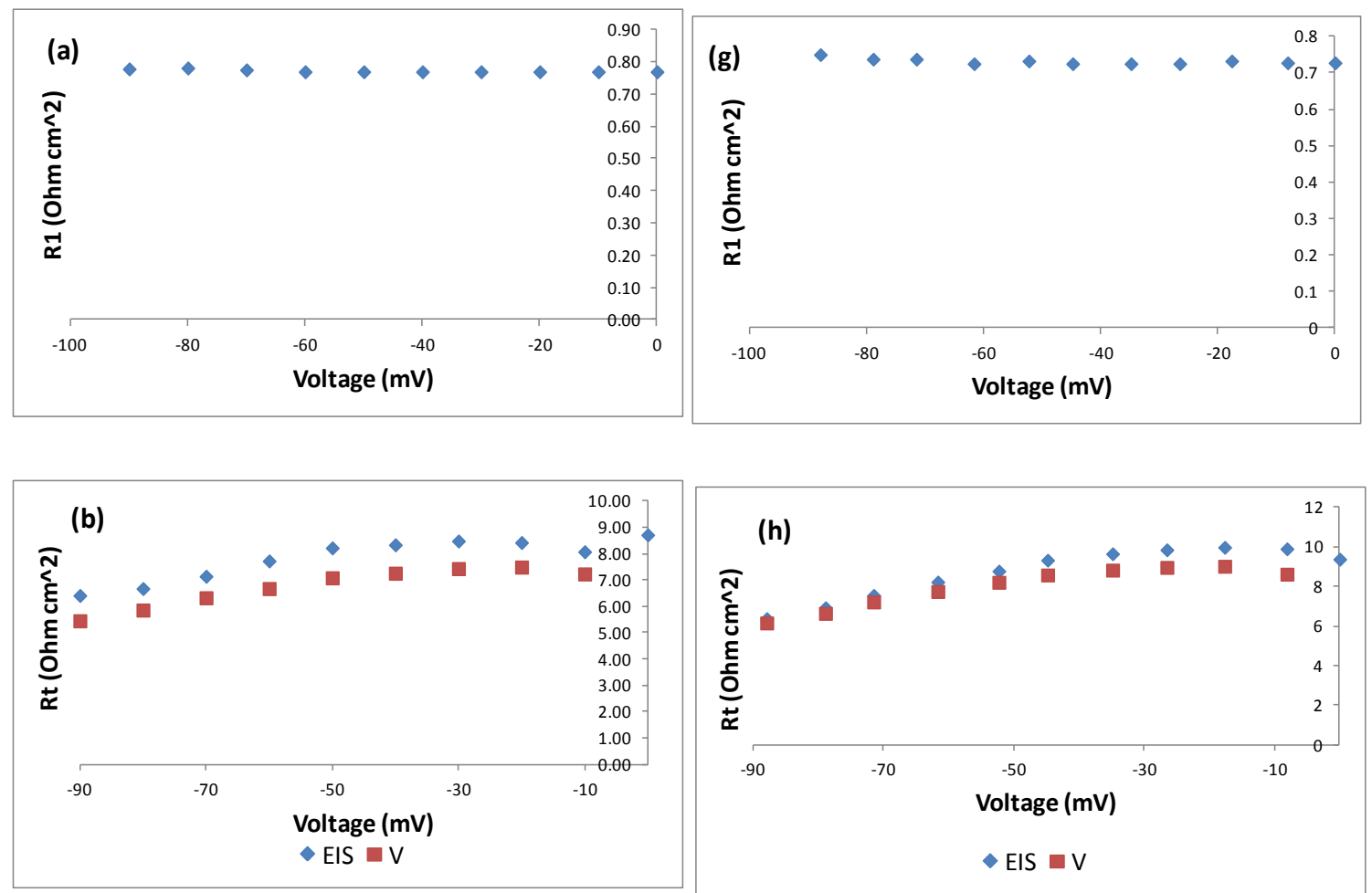

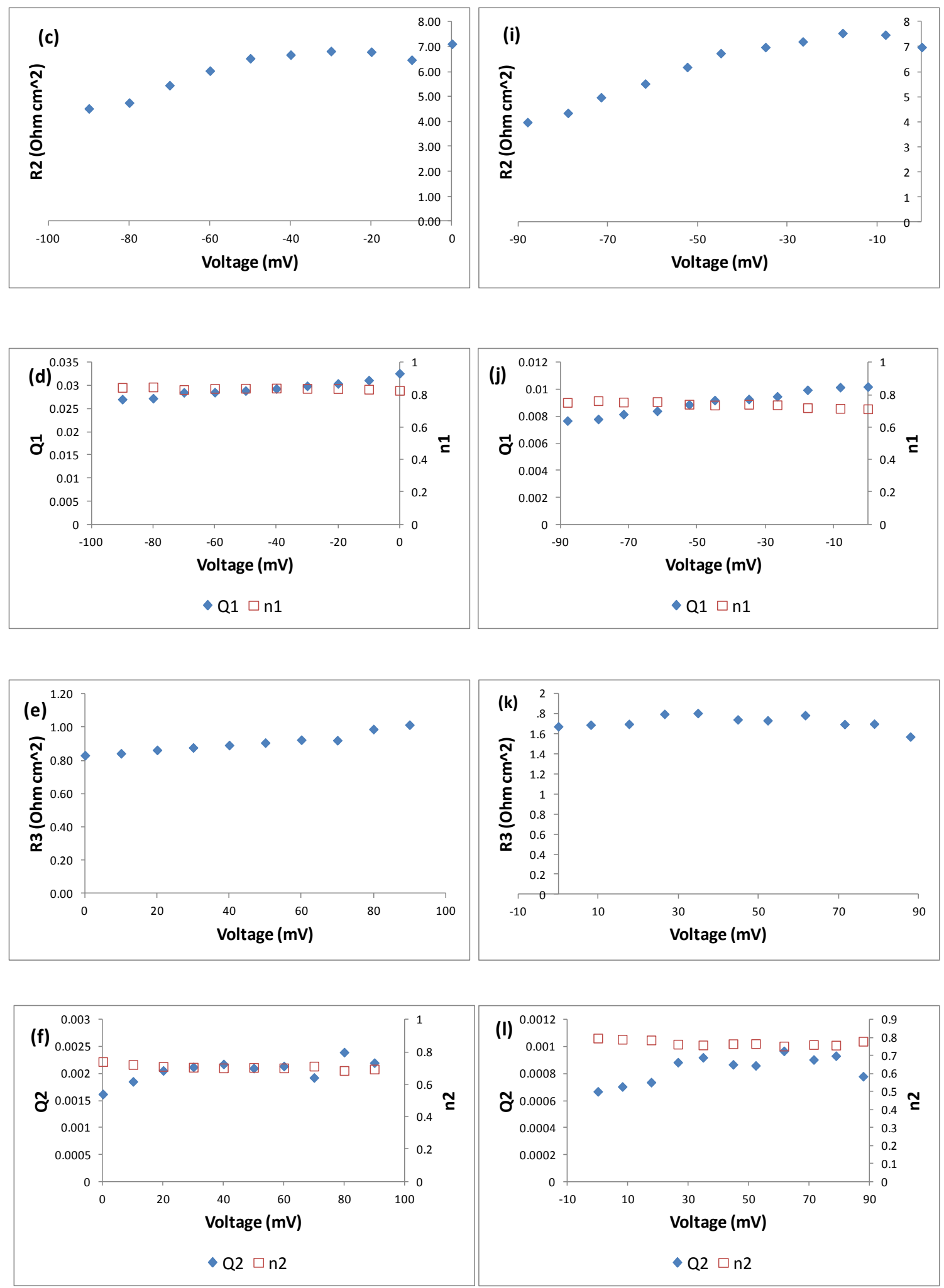

Figure 5.9: Fitting parameters of equivalent circuit elements used for impedance data collected for Cell A ((a)-(f)) and Cell B ((g)-(l)) under cathodic polarization at $800{ }^{\circ} \mathrm{C}$. Note the positive voltages for R3 and Q2 plots. 
Similar to the observations for the anodic polarization conditions, the series resistances stays almost constant while Rt and R2 show a decreasing trend with the cathodic polarization for both Cells A and B (Figure 5.9). However, the total resistance values calculated using potentiostatic/galvanostatic experiments (Figure 5.8) (red squares) are lower than the resistances calculated using impedance data (blue diamonds). The reason for this discrepancy might be due to a low frequency inductive loop that can result in a lower $\mathrm{X}$-axis intercept which would yield a lower Rt value. Figure 5.10 shows the appearance of low frequency inductance (red circle) in impedance data collected using negative current (LSM paste electrode as the cathode).
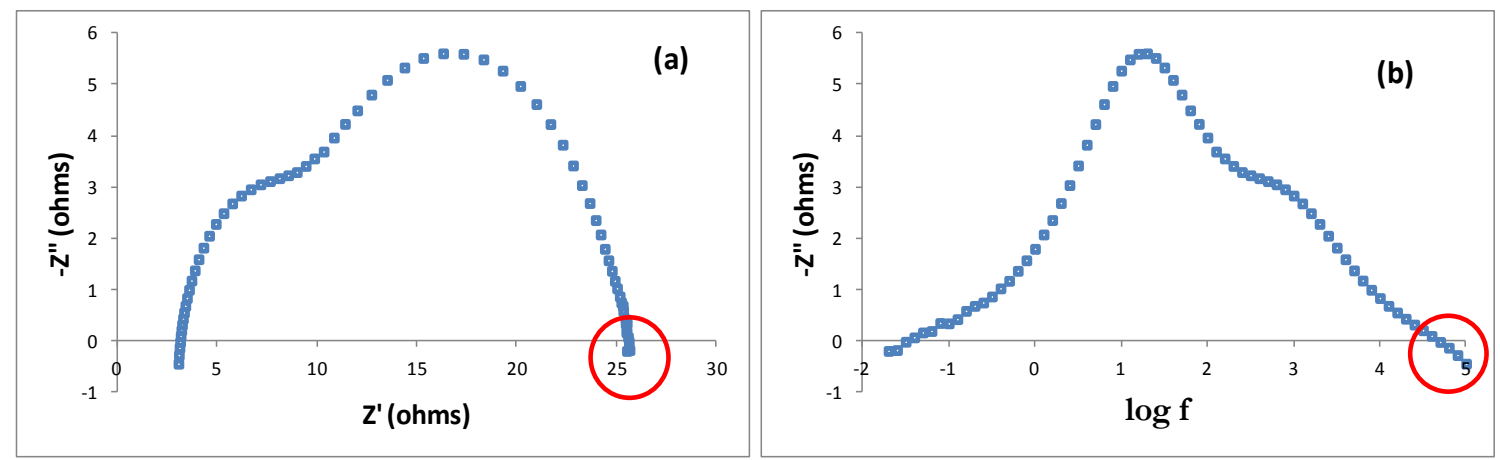

Figure 5.10: Cole-Cole plot (a) and Negative out of phase impedance vs log frequency plot (b) for a LSM/YSZ hvbrid cell under $-3.6 \mathrm{~mA}$ applied current at $800{ }^{\circ} \mathrm{C}$.

Q1 values which range from 0.008 to $0.03 \mathrm{Fcm}^{-2}$ (C values calculated using the equation mentioned before range from $\sim 2 \times 10^{-3} \mathrm{Fcm}^{-2}$ to $\sim 2 \times 10^{-2} \mathrm{Fcm}^{-2}$ ) show a decreasing pattern with applied negative bias for both Cells A and B. The value of Q1 is comparable with a capacitance for the gas phase - electrode interface or of the surface adsorption and diffusion process of oxygen. Also, as previously mentioned, the activation energy calculated for R2 (at OCV) favors a surface oxygen adsorption and diffusion process.

The low frequency arc due to gas phase oxygen diffusion impedance is not observed under cathodic conditions. For both Cells A and B, cathodic polarization experiments were carried out after they were anodically polarized which means that they may have undergone microstructural changes (if internal cracks occurred) to increase the porosity. Therefore the gas phase oxygen diffusion from the bulk to the reaction sites occur without restraint, so that this process is not prominent in the impedance spectrum. 
Furthermore, as mentioned in the experimental section, two impedance spectra were recorded (one after the other) at each condition. For most of the spectra, a slight drift in the impedance data was visible at low frequencies (Figure 5.11) suggesting that slow changes occur at the powder based LSM cathode.
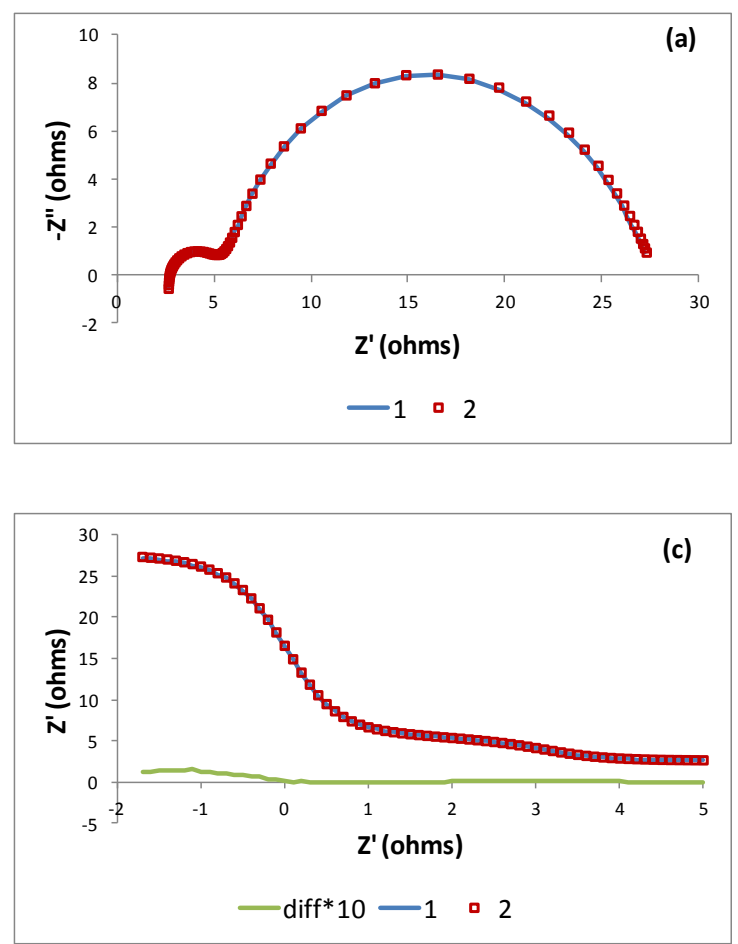

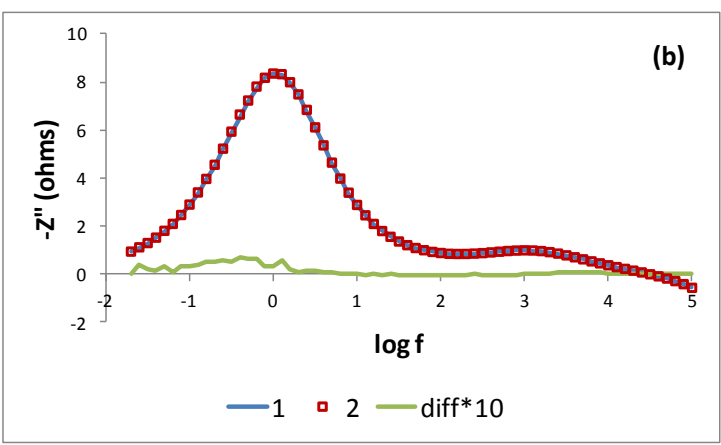

Figure 5.11: Cole-Cole plot (a) and Bode plots (b) and (c) showing the slight drift in impedance spectra at low frequencies for Cell $\mathrm{A}$ at $0.01 \mathrm{~V}$, $800{ }^{\circ} \mathrm{C}$.

As mentioned before, no attempt was made to analyze the oxygen reduction reaction on solution based LSM cathode with Ag current collector due to the expected complexity of the mechanism owing to the evidence of Ag current collector's participation in the oxygen reduction reaction. However, the trends of the parameters associated with the solution based cathode are presented with respect to applied cell voltage.

\section{Current - Over Voltage plots}

Current density is the area normalized applied current. The calculated current densities were multiplied by the respective area normalized resistances to calculate the overvoltages

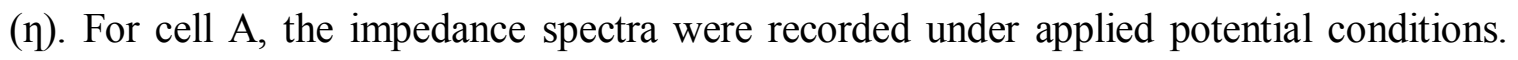
Therefore, the currents were calculated by dividing the applied voltages by the total resistance values (calculated from impedance data). 

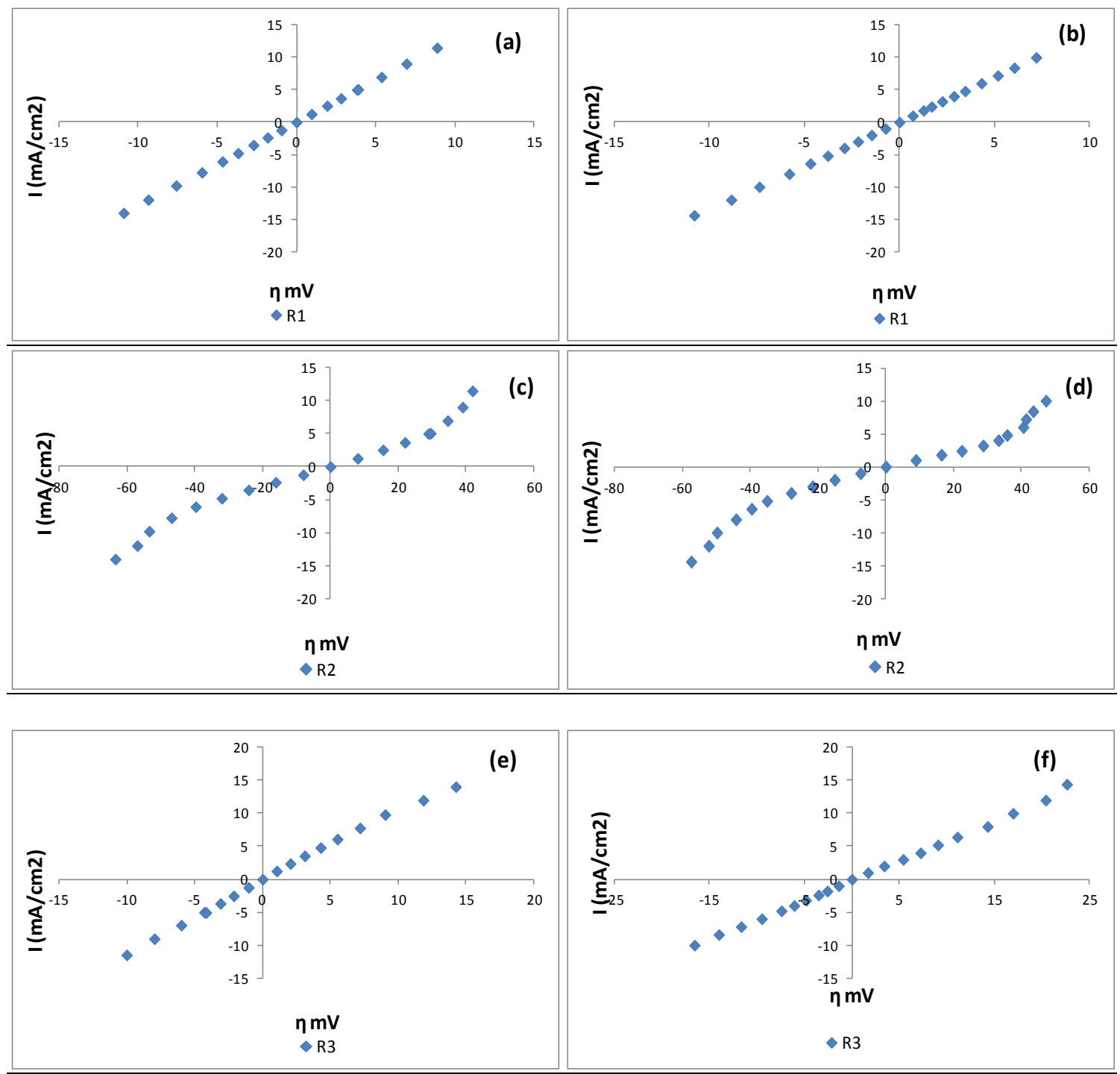

Figure 5.12: Current-over voltage plots for series resistance (R1), resistance for powder based LSM cathode (R2) and resistance for solution based LSM cathode (R3) of Cell A ((a), (c), (e)) and Cell B ((b), (d), (f)), respectively.

According to the current-over voltage plots in Figure 5.12, the series resistance (R1) and the resistance for solution based LSM cathode (R3) show Ohmic behavior which means these resistances are independent of the applied voltage. However, R2 does not show Ohmic behavior. The current-overvoltage plots resemble Butler-Volmer behavior. Researchers commonly use the Butler-Volmer equation (equation 5.2) when proposing a mechanism for oxygen reduction reaction and for computer simulations. However in order 
to describe a reaction using Butler-Volmer equation, only the current should change with the applied voltages and all the other parameters should remain constant.

Butler-Volmer equation:

$$
\mathrm{i}=\mathrm{i}_{0}\left(\exp \left(\left(\alpha_{\mathrm{A}}\right) \mathrm{f \eta}\right)-\exp \left(-\alpha_{\mathrm{C}} \mathrm{f \eta}\right)\right)
$$

$\mathrm{i}=$ current

$\mathrm{i}_{0}=$ exchange current

$\eta=$ over potential

$\alpha_{\mathrm{A}}=$ anodic transfer coefficient

$\alpha_{C}=$ cathodic transfer coefficient

In other words, the resistances, $\mathrm{Q}$ and $\mathrm{n}$ values measured at OCV should be constant, irrespective of the history of the cathode. However, our results (Table 5.3) show that the cathode properties were changing with the applied voltages. Hence, we cannot further analyze our data using the Butler-Volmer equation and deduce useful information.

Table 5.3: Parameters recorded for Cell A and Cell B at open circuit voltage $\left(800{ }^{\circ} \mathrm{C}\right)$.

\begin{tabular}{|c|c|c|c|c|c|c|c|c|c|c|}
\hline & Experiment & $\mathbf{R 2}$ & Q1 & n1 & R3 & Q2 & $\mathrm{n} 2$ & f1 & f2 & History \\
\hline \multirow{6}{*}{$\stackrel{\varangle}{\bar{\Xi}}$} & OCV1 & 5.95 & 0.0338 & 0.831 & 0.68 & 0.00229 & 0.726 & 1.10 & 1170 & $\begin{array}{l}\text { Initial } \\
\text { measurement }\end{array}$ \\
\hline & $\mathrm{OCV} 2$ & 6.65 & 0.0333 & 0.828 & 0.83 & 0.00190 & 0.735 & 0.98 & 1030 & $\begin{array}{l}\text { After } \\
\text { temperature } \\
\text { study }\end{array}$ \\
\hline & OCV3 & 7.11 & 0.0326 & 0.827 & 0.83 & 0.00162 & 0.740 & 0.93 & 1210 & After $+40 \mathrm{mV}$ \\
\hline & OCV4 & 5.77 & 0.0320 & 0.830 & 0.84 & 0.00175 & 0.730 & 1.22 & 1220 & After $+70 \mathrm{mV}$ \\
\hline & OCV5 & 6.12 & 0.0314 & 0.829 & 0.89 & 0.00163 & 0.733 & 1.17 & 1170 & After $-40 \mathrm{mV}$ \\
\hline & OCV6 & 4.81 & 0.0307 & 0.833 & 1.09 & 0.00153 & 0.731 & 1.59 & 1000 & After $-90 \mathrm{mV}$ \\
\hline \multirow{6}{*}{ 象 } & OCV1 & 6.39 & 0.0102 & 0.727 & 0.98 & 0.00059 & 0.826 & 7.00 & 1304 & $\begin{array}{l}\text { Initial } \\
\text { measurement }\end{array}$ \\
\hline & OCV2 & 7.78 & 0.0105 & 0.719 & 1.33 & 0.00065 & 0.808 & 5.00 & 979.9 & After T study \\
\hline & OCV3 & 10.7 & 0.0111 & 0.709 & 1.62 & 0.00074 & 0.790 & 3.00 & 803.4 & After $+45 \mathrm{mV}$ \\
\hline & OCV4 & 6.98 & 0.0102 & 0.713 & 1.67 & 0.00067 & 0.797 & 6.00 & 800 & After $+100 \mathrm{mV}$ \\
\hline & OCV5 & 7.49 & 0.0101 & 0.712 & 1.72 & 0.00068 & 0.796 & 6.00 & 774.3 & After $-45 \mathrm{mV}$ \\
\hline & OCV6 & 5.56 & 0.0094 & 0.717 & 1.80 & 0.00066 & 0.800 & 10.0 & 728.7 & After $-90 \mathrm{mV}$ \\
\hline
\end{tabular}



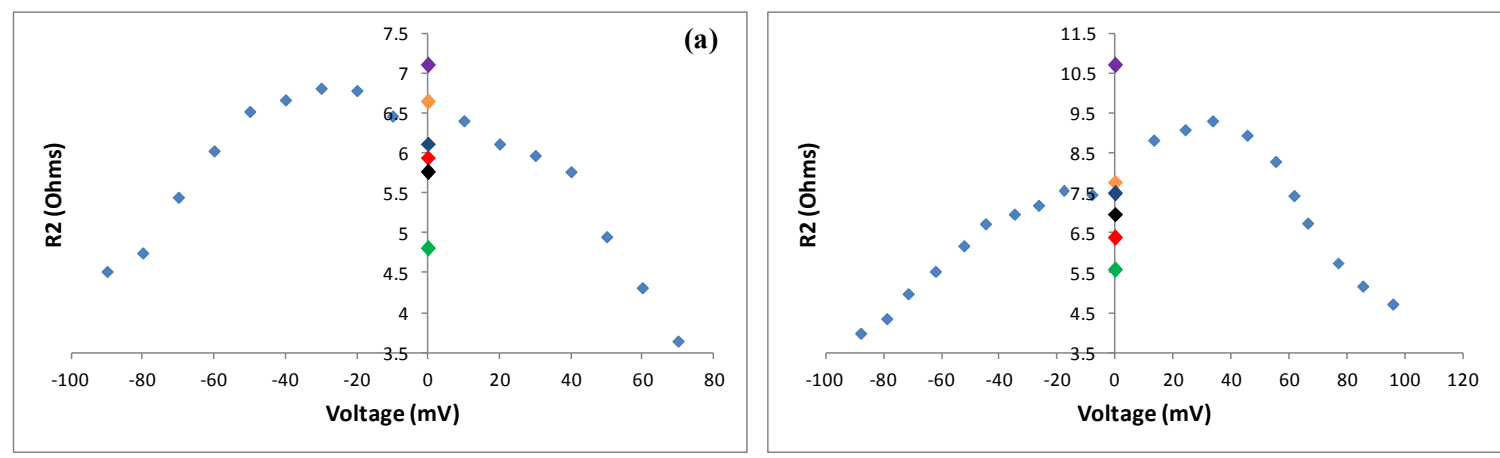

Figure 5.13: Resistance of the powder based LSM cathode as a function of the applied voltage for Cell A (a) and Cell B (b) respectively. Resistance values at open circuit voltages OCV 1 (red), OCV 2 (orange), OCV 3 (purple), OCV 4 (black), OCV 5 (blue) and OCV 6 (green) are shown in different colors.

As shown in Figure 5.13; for Cell A, R2 (paste electrode) initially increases after positive voltages $(+40 \mathrm{mV})$ and then decreases $(+70 \mathrm{mV})$. Q1 and $\mathrm{n} 1$ are approximately constant. After negative voltages, R2 initially increases $(-40 \mathrm{mV})$ and then sharply decreases (-90 $\mathrm{mV}$ ). Q1 decreases somewhat while $\mathrm{n} 1$ remains constant. Similarly, for Cell B, R2 (paste electrode) initially increases with positive voltages $(+45 \mathrm{mV})$ and then decreases $(+100 \mathrm{mV})$. Q1 and $\mathrm{n} 1$ are approximately constant. After negative voltages, R2 initially increases $(-45 \mathrm{mV})$ and then sharply decrease $(-90 \mathrm{mV})$. Q1 shows a decreasing trend and $\mathrm{n} 1$ remains constant. Based on previous discussion and the literature, the changes can be assigned to microstructural evolution of the LSM, or slow movement of cations towards or away from the surface. What is unique to this study is that the slow changes in polarization resistance are occurring for overpotentials less than $100 \mathrm{mV}$ and current densities less than $10 \mathrm{~mA} / \mathrm{cm}^{2}$. Most previous work has reported changes after large voltages or large currents.

As noted above, the slow changes in LSM properties prevent the use of the Butler Volmer equation to analyze the current-overvoltage patterns in Fig. 5.9. This observation suggests that many mathematical simulations of LSM cathodes which incorporate ButlerVolmer kinetics must be viewed with caution. 


\subsection{Summary}

LSM/YSZ hybrid cells were prepared using powder based and solution based LSM cathodes on each side of an YSZ electrolyte. Since the peak frequencies of processes for these two cathodes are several orders-of-magnitude apart, we are able to isolate and study the powder based LSM cathode independent of the other electrode. The solution based LSM cathode with Ag current collector was used merely as a counter electrode. However, observed parameters for both electrodes are presented for usefulness of further analysis.

A low frequency arc assigned to gas phase diffusion appeared with anodic polarization but not with the cathodic polarization. Comparison of the obtained parameters with the reported data in the literature supports the occurrence of the oxygen reduction reaction via surface path. However, further experiments are needed to support this hypothesis. Also, we are not able to analyze the data using Butler-Volmer equation since measurements at $\mathrm{OCV}$ show that the cathode is changing with applied voltages (in $\mathrm{mV}$ range).

\subsection{Conclusion}

LSM/YSZ hybrid cells provided a straightforward method to isolate and study only the powder based LSM cathode even under applied DC voltage/current. According to our knowledge, a direct method to study the behavior of a single electrode (with minimal effects from the other cell components) at applied DC voltages/currents had not been reported before.

Based on the parameters measured for the LSM cathode, hypotheses are presented for the oxygen reduction pathway. However, further experiments are needed for verification. Comparatively high peak frequencies associated with the solution based LSM cathodes (with Ag current collector) provides an opportunity to use them as counter electrodes when studying other different cathode materials with low peak frequency impedances.

Also, we have shown that the Butler-Volmer equation cannot be used to deduce mechanisms on cathodes that have changing properties with applied voltages. Furthermore, it would be worthwhile to investigate the changes associated with the powder based LSM 
cathode. After anodic polarization, the microstructure of the cathode can be analyzed to observe whether any "cracks" have occurred. Also, the cell can be kept at OCV for a longer time (as opposed to 15 minutes) to see whether any of these changes are reversible. These hybrid cell experiments can be continued with higher applied DC voltages/currents and also the experiment order can be changed (ie. Cathodic polarization followed by anodic polarization). 


\subsection{References}

1. Chen X., Aging Effects of the Cathode and Determination of Single Electrode Performance in a Solid Oxide Fuel Cell, Dissertation, West Virginia University, 2013

2. Fleig J., Annual Review of Materials Research, 2003, 33, 361-382

3. $\quad$ Adler S.B., Chemical Reviews, 2004, 104, 4791-4843

4. Kenney, B.A., An Experimental and Modeling Study of Oxygen Reduction in Porous LSM/YSZ Solid Oxide Fuel Cell Cathodes, Thesis, Queen's University, 2009

5. Brichzin, V., Fleig J., Habermeier H.-U., Cristiani G., Maier J., Solid State Ionics, 2002, 152-153, 499-507

6. la O' G. J., Yildiz B., McEuen S., Shao-Horn Y., Journal of Electrochemical Society, 2007, 154 (4), B427- B438

7. Chen X.J., Khor K.A., Chan S. H., Journal of Power Sources, 2003, 123, 17-25

8. $\quad$ Siebert E., Hammouche A., Kleitz M., Electrochimica Acta, 1995, 40 (11), 17411753

9. Fleig J., Baumann F.S., BrichzinV., Kim H.-R., Jamnik J., Cristiani G., Habermeier H.-U., Fleig J.M., Fuel Cells, 2006, 3-4, 284-292

10. Brichzin, V., Fleig J., Habermeier H.-U., Maier J., Electrochemical and SolidState Letters, 2000, 3(9), 403-406

11. Ostergard M., Mogensen M., Electrochimica Acta, 1993, 38(14), 2015-2020

12. Fleig J., Kim J., Jamnik J., Maier J., Fuel Cells, 2008, 8(5), 330-337

13. Van Herle J., McEvoy E., Thampi K., Electrochimica Acta, 1996, 41(9), 14471454

14. Jiang S.P., Love J.G., Ramprakash Y., Journal of Power Sources, 2002, 110, 201208

15. Murray E.P., Tsai T., Barnett S.A., Solid State Ionics, 1998, 110, 235-243

16. Jiang S.P., Journal of Solid State Electrochemistry, 2007, 11, 93-102

17. Huber A-K., Falk M., Rohnke M., Luerßen B., Gregoratti L., Amati M., Janek J., Physical Chemistry Chemical Physics, 2012, 14, 751-758 
18. Huber A-K., Falk M., Rohnke M., Luerßen B., Amati M., Gregoratti L., Hesse D., Janek J., Journal of Catalysis, 2012, 294, 79-88

19. la O’ G. J., Savinell R.F., Shao-Horn Y., Journal of Electrochemical Society, 2009, 156 (6), B771-B781

20. Jiang S.P., Journal of Materials Science, 2008, 43, 6799-6833 


\section{Appendix A}
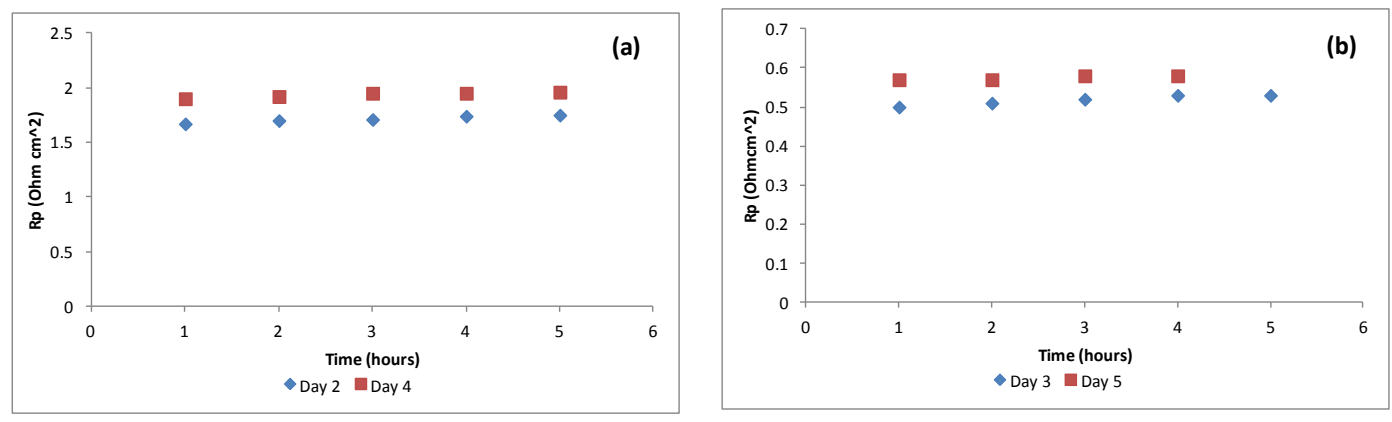

Figure 1: Polarization resistances recorded over time during the aging experiment for organic LSM solution cathode (with Ag current collector) sintered at $900{ }^{\circ} \mathrm{C}$ on YSZ at (a) $700{ }^{\circ} \mathrm{C}$ and (b) $800{ }^{\circ} \mathrm{C}$.
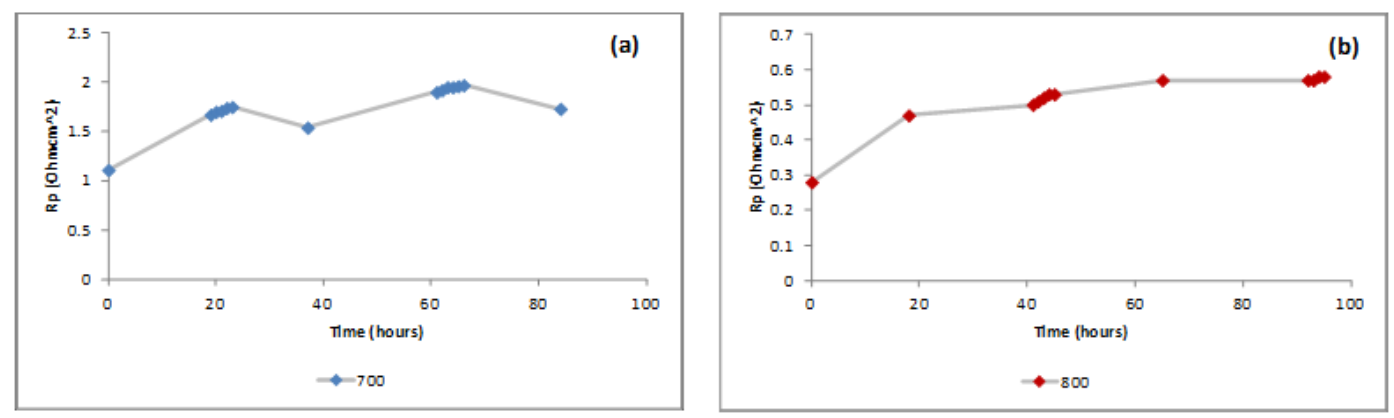

Figure 2: Polarization resistances recorded at (a) $700{ }^{0} \mathrm{C}$ and (b) $800{ }^{0} \mathrm{C}$ for aging of organic LSM solution cathode (with Ag current collector) sintered at $900{ }^{\circ} \mathrm{C}$ on YSZ.
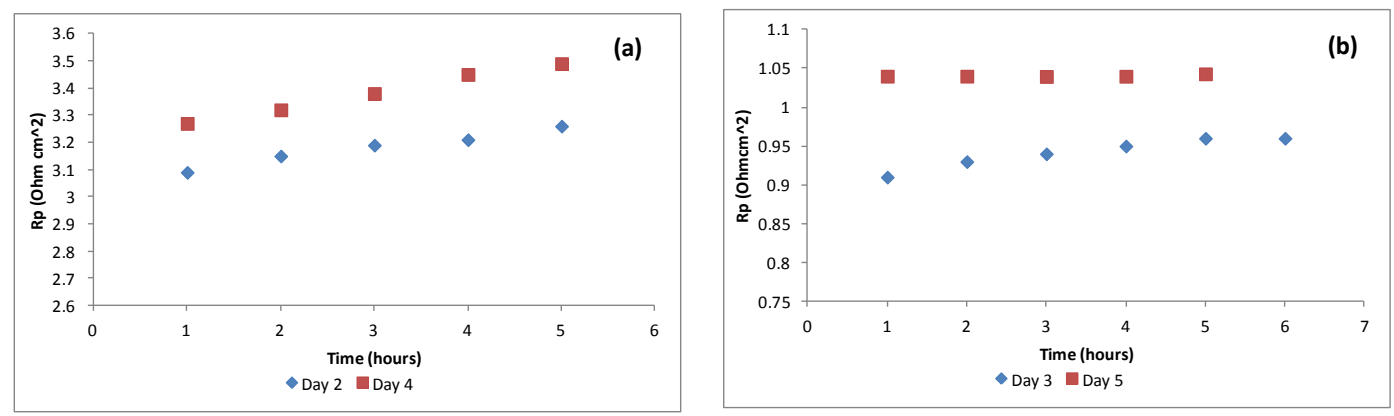

Figure 3: Polarization resistances recorded over time during the aging experiment for aqueous LSM solution cathode (with Ag current collector) sintered at $800{ }^{\circ} \mathrm{C}$ on YSZ at (a) $700{ }^{\circ} \mathrm{C}$ and (b) $800{ }^{\circ} \mathrm{C}$. 

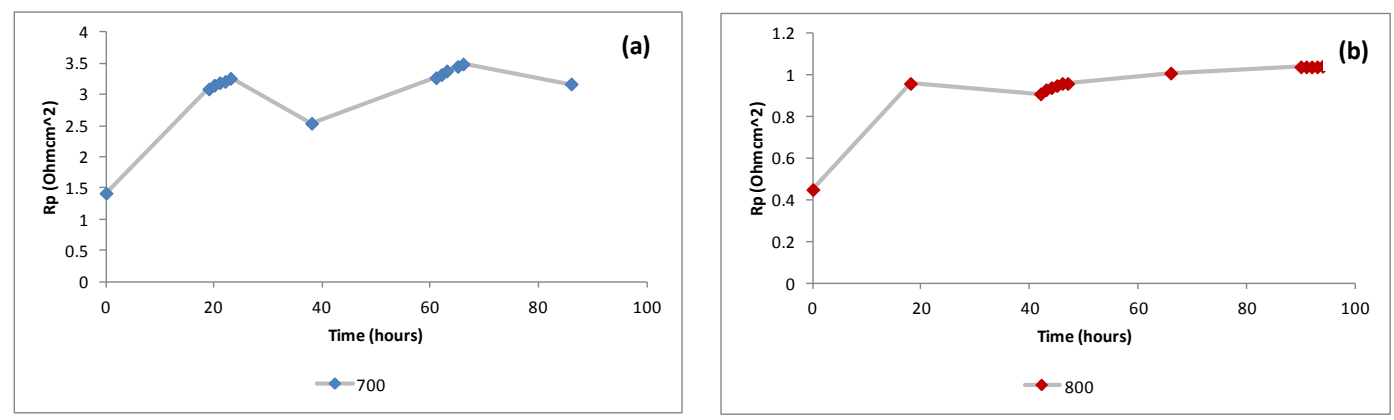

Figure 4: Polarization resistances recorded at (a) $700{ }^{0} \mathrm{C}$ and (b) $800{ }^{0} \mathrm{C}$ for aging of aqueous LSM solution cathode (with Ag current collector) sintered at $800{ }^{\circ} \mathrm{C}$ on YSZ.
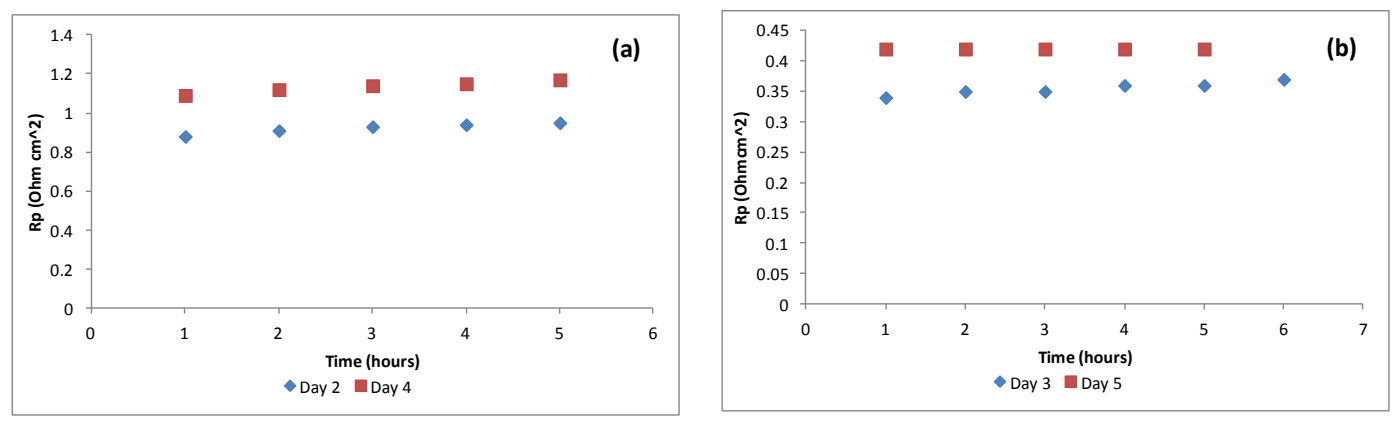

Figure 5: Polarization resistances recorded over time during the aging experiment for aqueous LSM solution cathode (with Ag current collector) sintered at $900{ }^{0} \mathrm{C}$ on YSZ at (a) $700{ }^{\circ} \mathrm{C}$ and (b) $800{ }^{0} \mathrm{C}$.
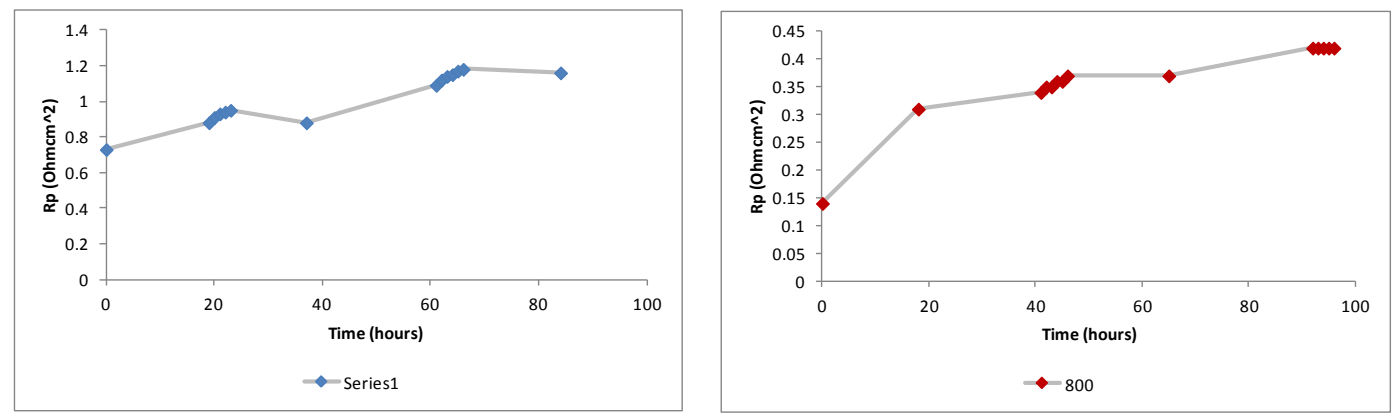

Figure 6: Polarization resistances recorded at (a) $700{ }^{0} \mathrm{C}$ and (b) $800{ }^{0} \mathrm{C}$ for aging of aqueous LSM solution cathode (with Ag current collector) sintered at $900{ }^{\circ} \mathrm{C}$ on YSZ. 


\section{PREPARATION OF SOLID OXIDE FUEL CELL CATHODES AND ANALYSIS BY IMPEDANCE SPECTROSCOPY}

Juwana Hennadige Lalanthi Kaushalya de Silva

Dissertation submitted to the Eberly College of Arts and Sciences at West Virginia University in partial fulfillment of the requirements for the degree of

Doctor of Philosophy in Chemistry

C. Eugene Bennett Department of Chemistry

APPROVAL OF THE EXAMINING COMMITTEE

Fabien Goulay, Ph.D.
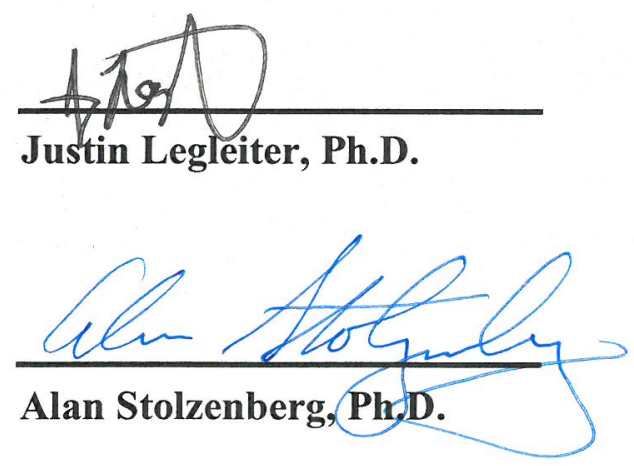

$11 / 14 / 2014$

Date

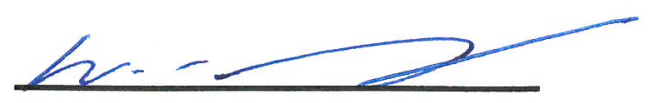

Nianqiang Wu, Ph.D. 